US Army Corps

of Engineers $s_{\circledast}$

Engineer Research and

Development Center

\title{
Geomorphic Investigation of the Great Bend Region, Red River
}

Paul E. Albertson, Maureen K. Corcoran,

August 2018

Whitney J. Autin, John Kruger, and Theresa Foster 
The U.S. Army Engineer Research and Development Center (ERDC) solves the nation's toughest engineering and environmental challenges. ERDC develops innovative solutions in civil and military engineering, geospatial sciences, water resources, and environmental sciences for the Army, the Department of Defense, civilian agencies, and our nation's public good. Find out more at www.erdc.usace.army.mil.

To search for other technical reports published by ERDC, visit the ERDC online library at http://acwc.sdp.sirsi.net/client/default. 


\section{Geomorphic Investigation of the Great Bend Region, Red River}

Paul E. Albertson and Maureen K. Corcoran

Geotechnical and Structures Laboratory

U.S. Army Engineer Research and Development Center

3909 Halls Ferry Road

Vicksburg, MS 39180-6199

Whitney J. Autin and John Kruger

Louisiana State University

Department of Geology \& Geophysics

E235 Howe-Russell-Kniffen Geoscience Complex

Baton Rouge, LA 70803

Theresa Foster

San Diego State University

Department of Geological Sciences

5500 Campanile Drive

San Diego, CA 92182-1020

Final report

Approved for public release; distribution is unlimited.

Prepared for U.S. Army Engineer District, Vicksburg 4155 Clay St.

Vicksburg, MS 39183 


\section{Abstract}

The U.S. Army Engineer District, Vicksburg, conducted feasibility studies to rehabilitate the levees along the Red River from Fulton, AR, to the Arkansas-Louisiana state line. In support of these studies, research was performed by the U.S. Army Engineer Research and Development Center to provide a geomorphic framework for cultural resources in the project area. This research had three specific objectives: (1) identify and map geomorphic features in the study area on 1:24,000 scale maps, (2) define geomorphic processes that are active in the study area, and (3) reconstruct the geomorphic development of the study area to understand the significance of geomorphic features in terms of both locating previously unknown archaeological sites and discovering buried sites. Field investigations and aerial photography were used to interpret the geomorphology. Approximately 6 percent of the known archeological sites are located above the floodplain on valley slopes or bluffs. The remaining 94 percent of the sites are associated with the floodplain of the various fluvial components that form the study area. Forty-six percent of floodplain sites are located adjacent to crevasse channels. Other known archaeological sites are primarily located on the natural levee or adjacent point bars.

DISCLAIMER: The contents of this report are not to be used for advertising, publication, or promotional purposes. Citation of trade names does not constitute an official endorsement or approval of the use of such commercial products. All product names and trademarks cited are the property of their respective owners. The findings of this report are not to be construed as an official Department of the Army position unless so designated by other authorized documents. 


\section{Contents}

Abstract............................................................................................................................. ii

Figures and Tables..................................................................................................vi

Preface .........................................................................................................................vii

1 Introduction ...................................................................................................... 1

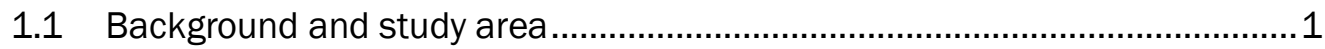

1.2 Purpose and scope ........................................................................... 1

1.3 Previous investigations..................................................................

2 Procedure ........................................................................................................... 5

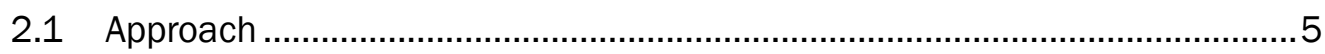

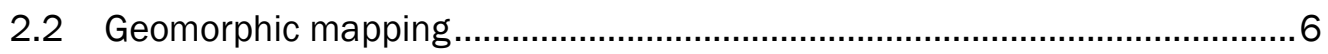

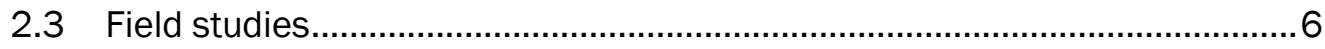

2.3.1 Objectives and approach ........................................................................... 6

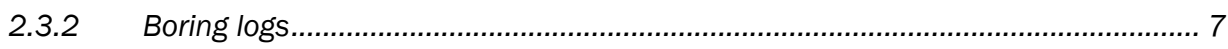

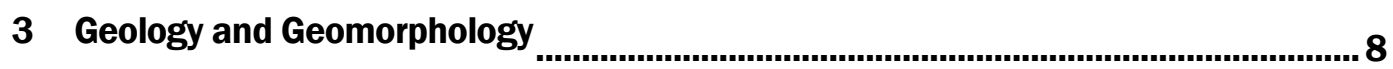

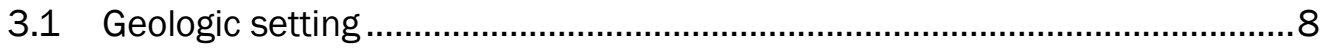

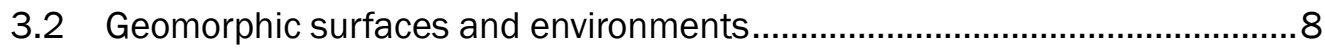

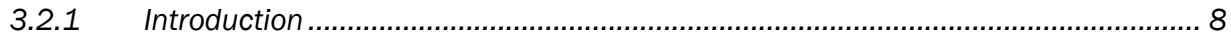

3.2.2 Bluff slopes and tertiary sediments ................................................................. 10

3.2.3 Terrace (Pi) .............................................................................................. 10

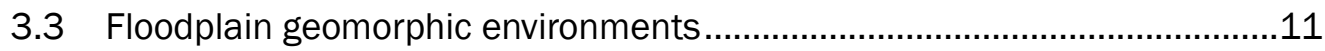

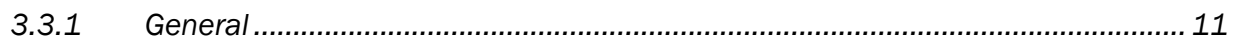

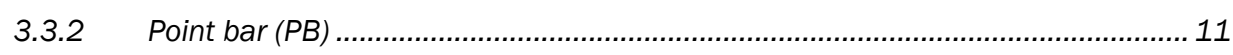

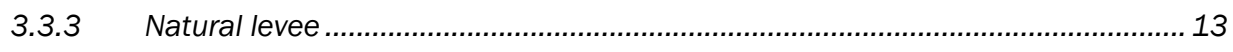

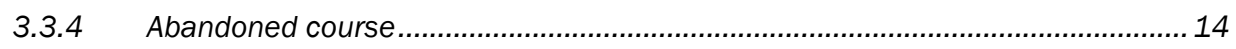

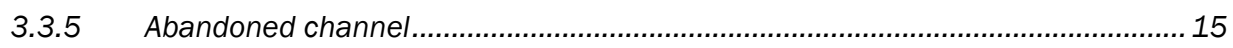

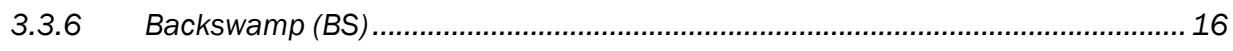

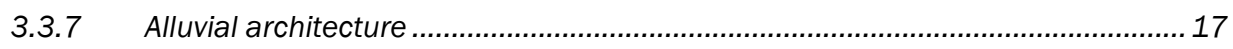

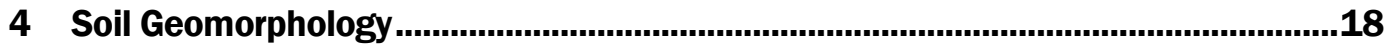

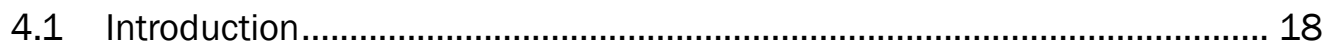

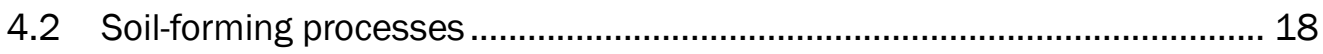

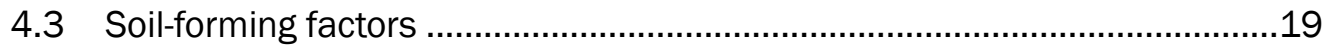

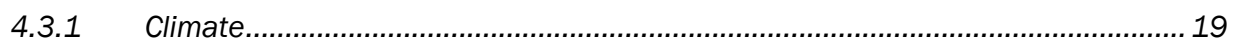

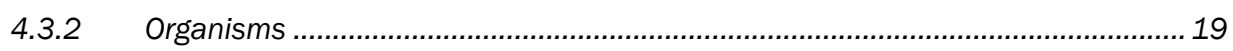

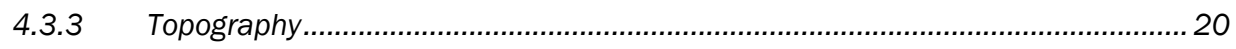

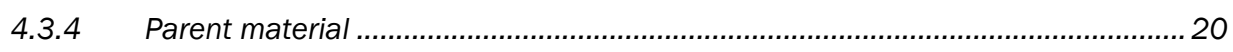

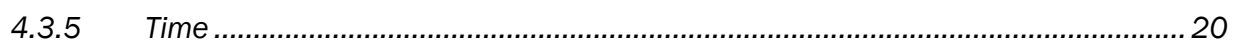

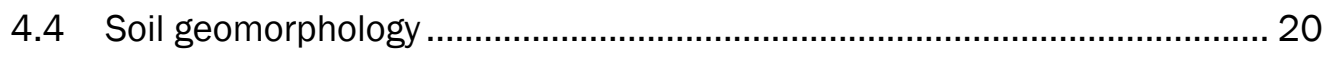




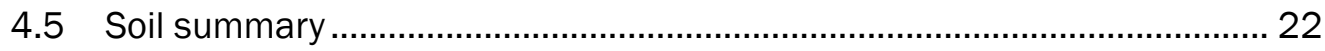

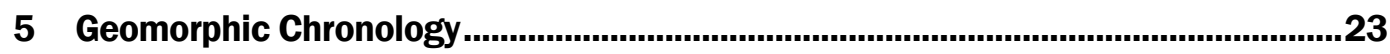

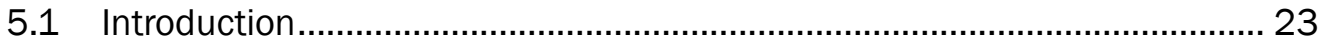

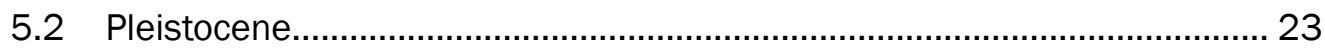

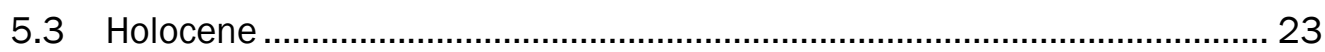

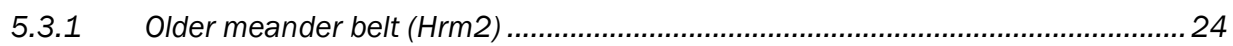

5.3.2 Intermediate meander belt (Hrm1.1 and 1.2) ................................................25

5.3.3 Modern meander belt (Hrm1.0) ..................................................................... 25

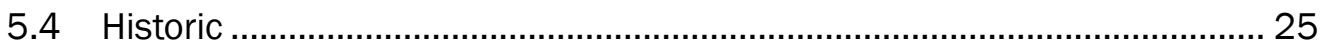

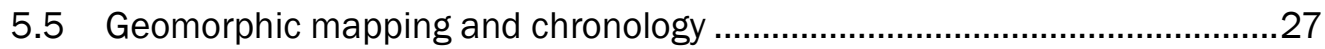

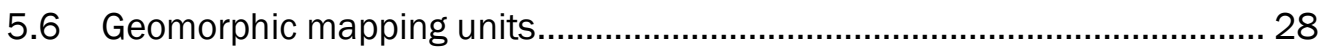

6 Significance of Geomorphology to Cultural Resources .....................................30

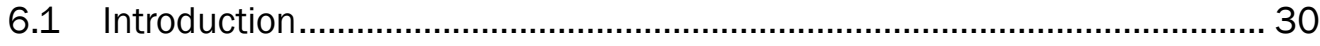

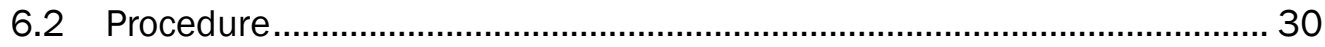

6.2.1 Use of GIS in cultural resource assessment...................................................... 31

6.2.2 Data requirements for cultural resource assessment .......................................... 32

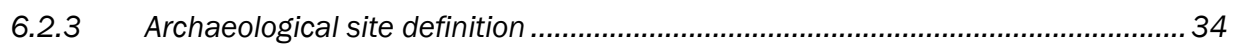

6.2.4 Characteristics of an archaeological site ............................................................34

6.3 Distribution of known archaeological sites .................................................. 35

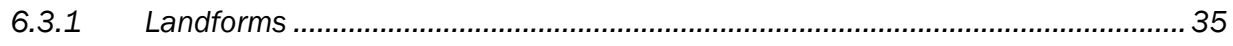

6.3.2 Distribution of cultural components .................................................................

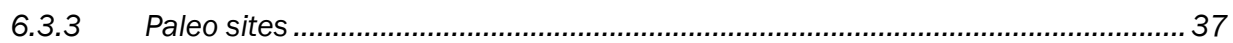

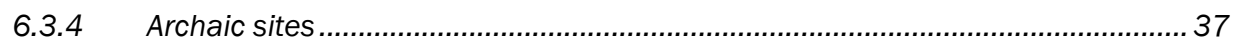

6.3.5 Fourche Maline sites............................................................................. 37

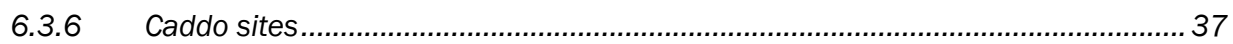

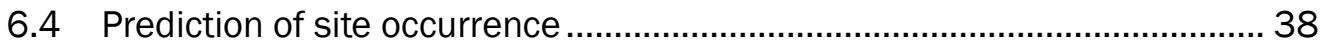

6.5 Site preservation and destruction ............................................................ 39

6.6 Geomorphic evidence and archaeological significance of

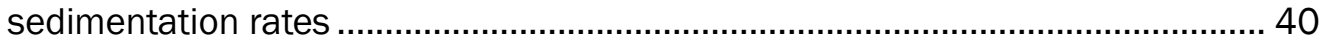

6.6.1 Geomorphic evidence and sedimentation model ............................................. 40

6.6.2 Discussion .................................................................................................. 41

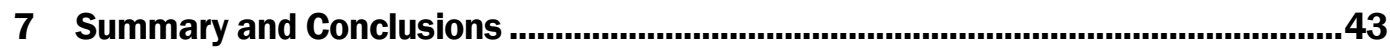

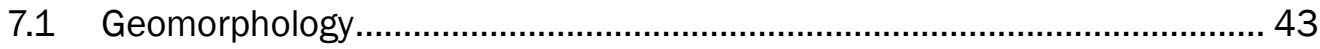

7.2 Archaeological significance ................................................................... 43

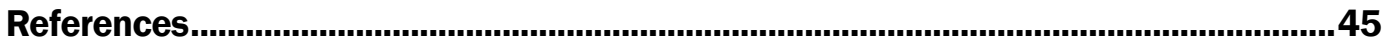

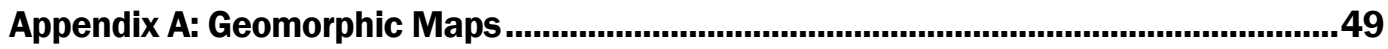

Appendix B: Geomorphic and Geologic Cross Sections..........................................59

Appendix C: Red River Boring Log Reference Table .................................................... 72

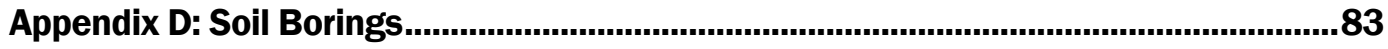


Appendix E: Radiometric Age Dates

168

Report Documentation Page 


\section{Figures and Tables}

\section{Figures}

Figure 1. Levee project map from Fulton, AR, to Arkansas-Louisiana state line with Fulton Quadrangle study area. ................................................................................ 2

Figure 2. Depositional environments of a meandering river.............................................. 9

Figure 3. Schematic and aerial view (from Saucier 1994) of a typical point bar depositional environment.

Figure 4. Schematic and aerial view (from Saucier 1994) of a typical natural levee depositional environment.

Figure 5. Schematic and aerial view (from Saucier 1994) of a typical abandoned course depositional environment.

Figure 6. Schematic and aerial view (from Saucier 1994) of a typical abandoned channel depositional environment.

Figure 7. Schematic and aerial view (from Saucier 1994) of a typical backswamp environment.

Figure 8. An artist's conception of the Great Raft. Note the overflow anabranch and distributary channels (Veatch 1906).

Figure 9. Location and limits of Poston Lake (Veatch 1906).

Figure 10. Distribution of archaeological sites by landform.

\section{Tables}

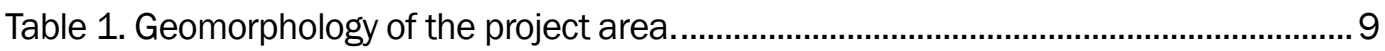

Table 2. Pleistocene terrace correlation chart.....................................................................

Table 3. Expected distribution of cultural resources by meander belts..............................38

Table 4. Geomorphology of the Red River Levee Rehabilitation Project area..................... 41 


\section{Preface}

This study was conducted for the U.S. Army Engineer District, Vicksburg under MIPR CELMK-PD-Q-94-5990 to conduct a geomorphic investigation of the Red River from Fulton, AR to the Arkansas-Louisiana state line. The program manager was Mr. Erwin Roemer, Vicksburg District.

The work was performed by a predecessor organization of the Geotechnical Engineering and Geosciences Branch (GEGB) of the Geosciences and Structures Division (GSD), U.S. Army Engineer Research and Development Center, Geotechnical and Structures Division (ERDC-GSL), Louisiana State University, and San Diego State University. At the time of publication, Mr. Chris Price was Chief, GEGB; Mr. James Davis was Chief, GSD; and Dr. Maureen K. Corcoran was the Acting Technical Director for Water Resources Infrastructure Research. The Deputy Director for ERDCGSL was Dr. William P. Grogan, and the Director was Mr. Bartley P. Durst.

COL Ivan P. Beckman was the Commander of ERDC, and Dr. David W. Pittman was the Director. 


\section{Introduction}

\subsection{Background and study area}

The U.S. Army Engineer District, Vicksburg, conducted feasibility studies to rehabilitate the levees along the Red River from Fulton, AR, to the Arkansas-Louisiana state line. The proposed project was designed to raise and strengthen the existing levee system along the Red River below Denison Dam. Rehabilitation between Fulton, AR, and the Louisiana state line consists of separate items representing reaches of levee. The geomorphology of the Red River Valley, Great Bend Region, is discussed in general, while the site-specific details were extracted from geomorphic maps and cross sections. Figure 1 shows the location mapped in the Great Bend region by this study.

\subsection{Purpose and scope}

The purpose of this investigation was to provide a geomorphic framework for cultural resources research in the project area. There were three specific objectives of this investigation: (1) identify and map geomorphic features or landforms in the study area on 1:24,000 scale base maps, (2) define geomorphic processes that are active in the study area, and (3) reconstruct, to the extent possible, the geomorphic development of the study area to understand the significance of geomorphic features in terms of both locating previously unknown archaeological sites and discovering buried sites.

\subsection{Previous investigations}

Several studies relate either directly or indirectly to the project area. The Red River has attracted exploration since early European expansion into North America. In 1687, René-Robert Cavelier, Sieur de La Salle, a French explorer, camped upstream of the Great Bend on the Red River (Santeford 1994). Louis Juchereau de St. Denis, a French-Canadian explorer and entrepreneur, established the trading post of Natchitoches in 1714 at the toe of the Great Raft (Guardia 1933). In 1719, Bernard de la Harpe, another French explorer, traveled farther up the Red River to the confluence of the Sulphur River and established a trading post in the region from 1719 to 1778 (Santeford 1994). 
Figure 1. Levee project map from Fulton, AR, to Arkansas-Louisiana state line with Fulton Quadrangle study area.

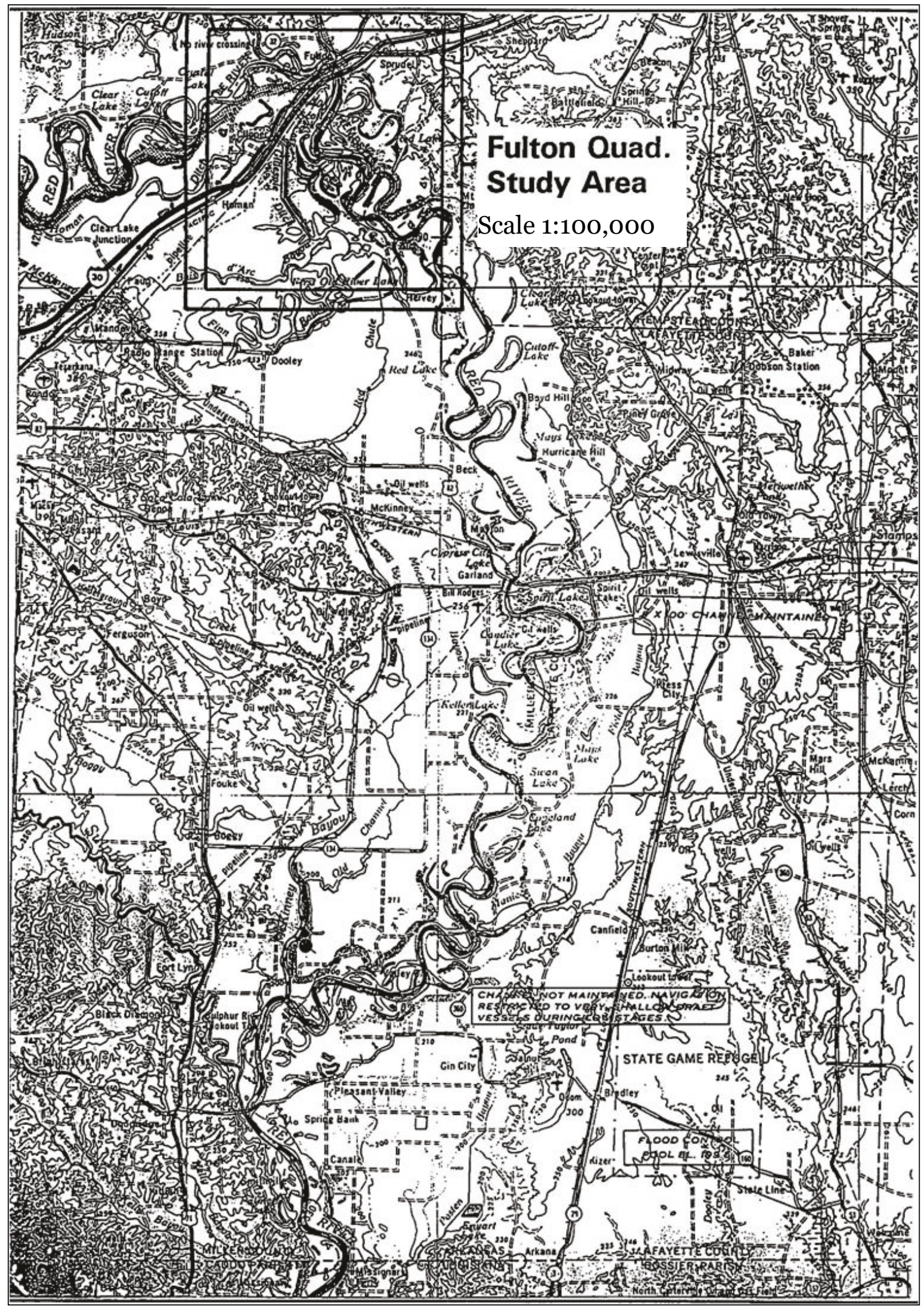


"Historically, the amount of interest in the ... Red River is directly related to the perceived value of land in question" (Jacobs 1985). The land area later to become Miller County, AR, became part of United States territory in 1803 with the Louisiana Purchase. The report by Dunbar (1804) is an example of President Thomas Jefferson's scientific interest in the newly acquired territory. In 1806, Jefferson sent Thomas Freeman and Dr. Peter Curtis to further explore the Red River Valley. Details of the expedition with a description of the Miller County area are found in Flores (1984). Other early 19th century accounts (Stoddard 1812; Darby 1816; and Flint 1833) described the anastomosing flow of the Red River due to the effects of the log jams known as the Great Raft. Captain Henry Shreve removed the raft as far as Coats Bluff (later named Shreveport) in the 1830s. The U.S. Army Corps of Engineers (USACE) completed removal of the log jam rafts to the Arkansas-Louisiana state line in 1873. Lt. Woodruff's report (USACE 1873) to Congress gives a photographic record of river conditions in the region.

The period of modern investigation may be said to begin with the work of Veatch (Schultz and Krinitzsky 1950). Veatch's (1906) report describes the geological history of the region and focused on raft processes and responses. Some of the classical geological investigations of the Red River Valley were conducted downstream of the levee rehabilitation reach. Fisk (1938) introduced the fundamentals of differentiating the Holocene alluvium into depositional environments and the Pleistocene into a four terrace sequence. Fisk's concepts were extended up the river in Schultz and Krinitzsky (1950), which included the alluvial geology, geological history, and their geological engineering significance. Harms et al. (1963) studied the stratification and sedimentary structure of point bars in the Shreveport, LA, vicinity.

Abington (1973) described and analyzed the Red River's changing meandering morphology. Abington's process-response model concluded that the Red River meandering is reducing its sinuosity and is in transition to a braided regime. Smith and Russ (1974) provided geological maps and cross sections at a scale of $1: 62,500$ that provide the most complete geological mapping of the study area until the present geomorphic investigation. Russ (1975) is the accompanying text to the Smith and Russ (1974) mapping. Russ (1975) offered a chronology for five meander belts in the lower Red River Valley with the youngest belt being less than 600 years B.P. 
Smith (1982) extrapolated Russ's framework to describe the geomorphic development of Bayou Bodcau and its significance to locating archeological sites. Pearson (1982) offered a working hypothesis of the meander belts of the Red River in the Great Bend region to archeological site potential and preservation proposing the idea of the modern, intermediate, and older meander belts. Jacobs $(1981,1985)$ differentiated five terraces and related archeological potential of each surface. Soils of Miller County, AR, were mapped in 1984 and in adjacent Hempstead County in 1979. Harvey et al. (1987) conducted both geomorphic and hydraulic analysis of the Red River above Shreveport. Saucier and Snead's (1989) synoptic 1:1,100,000 scale Quaternary Geology of The Lower Mississippi Valley Map depicts the latest two meander belts in the Great Bend region (i.e., Hrm1 and Hrm2). Earlier, Saucier (1974) stated that “... the chronology of the meander belts for this stream is quite tentative."

Albertson (1992) conducted engineering geology mapping south of the project area to locate sources of construction material and to provide foundation data for engineering structures associated with the proposed Shreveport to Daingerfield navigation project. Albertson and Dunbar (1993) conducted detailed geomorphic mapping for the proposed navigation project and related it to the archaeological significance of the area. Recent work by Heinrich (1993) and Guccione (1995) described geomorphology and sedimentation rates in other parts of the river system. 


\section{Procedure}

\subsection{Approach}

The geomorphic evaluation of the Great Bend study area was approached by:

1. reviewing previous literature, including geological and soil maps

2. interpreting geomorphology from aerial photographs

3. conducting field reconnaissance and shallow auger borings

4. compiling existing subsurface boring data that included USACE revetments and levee studies, Arkansas Department of Transportation (DOT) borings, and water wells

5. constructing geomorphic cross sections

6. synthesizing data into soil geomorphic maps with inferred age relationships

7. incorporating pertinent data into a geographic information system (GIS)

8. comparing temporal landforms to the known archeological record

The study was conducted in several phases. Following the literature review, a preliminary investigation involved geomorphic mapping based on a field reconnaissance of the project area. Building on the first three steps of the geomorphic evaluation, both site specific stratigraphic and chronological characteristics about the different depositional environments within the study area were determined in steps 1, 5, and 6 . Essential information (e.g., soil, geology, and archeological site data) was entered in a GIS database to better maintain and interpret the data. The GIS serves as an analytical tool to examine soil-geomorphic and archeological relationships. The GIS is a dynamic document (i.e., it will change with time as additional data are incorporated into it and new attributes are defined). Once a GIS structure is established, it can be modified to meet many purposes of land-use planning and resource management. The GIS, as originally created, is described in Chapter 6 of this report, and its use for relating geomorphic landforms and processes to both known and potential cultural resources is explained. 


\subsection{Geomorphic mapping}

The first objective of the geomorphic mapping was to identify the geomorphic features within the study area. Mapping was performed at a scale of 1:24,000 using a U.S. Geological Survey (USGS) quadrangle as a base map. Geomorphic features were defined and delineated primarily by analysis of topographic data, soil survey information, and aerial photography (i.e., black and white photography flown in 1959, 1983, 1989, and 1990). Some information sources, such as historic maps, were examined but not rigorously analyzed. In addition to these data, the geomorphic mapping was based and guided by previous studies conducted by the U.S. Army Engineer Waterways Experiment Station (WES) (Smith and Russ 1974; Smith 1982; Saucier and Snead 1989; Albertson 1992; and Albertson and Dunbar 1993). These studies served as the foundation for the aerial photographic interpretation. The results of the geomorphic mapping are in Appendices A and B of the report.

\subsection{Field studies}

\subsubsection{Objectives and approach}

The objectives of the field studies were to confirm the results of the geomorphic mapping and conduct soil sampling of selected geomorphic environments. Soil samples were used to develop both specific stratigraphic and chronological properties in the study area. Two visits were made to the project area as part of the field work. A general reconnaissance was conducted during this first phase to evaluate the results of previous geomorphic mapping. During the field investigation, auger soil sampling was conducted of selected geomorphic environments to correlate general soil properties with various geomorphic environments. Soils data were used to define sedimentological characteristics of different geomorphic environments to aid in reconstructing the evolution of the study area. Soil samples were visually inspected and logged on-site. Additional soils information was obtained from boring data and published literature. Boring data included existing Vicksburg District borings and borings drilled during the levee rehabilitation project (see Appendix $\mathrm{C}$ for reference table). Published soil data consisted of county soil survey bulletins from the Soil Conservation Service $(1979,1984)$. 


\subsubsection{Boring logs}

Logs of auger borings drilled during this study are presented in Appendix D. Boring logs contain descriptions of soil type, color (Munsell), texture, soil structure, consistency, and stratigraphic thickness. Boring locations are identified on the logs and are shown on the geomorphic maps. 


\section{Geology and Geomorphology}

\subsection{Geologic setting}

The Red River headwaters are in the arid High Plains of eastern New Mexico in an area named the Llano Estacado. The Red River flows east and forms the Texas-Oklahoma border. In Arkansas, the river turns south at Fulton and forms the Great Bend. Geomorphic development of the Red River Great Bend Region is the result of geologic processes operating during the last 65 million years. Surface deposits in the study area are Tertiary ( 2 to 65 million years) to Quaternary (2 million years to present) in age. Tertiary sediments were deposited by fluvial-deltaic processes similar to processes active in present-day Louisiana. These sediments were incised by numerous Pleistocene and younger fluvial systems, such as Red River meander belts. This study focuses on the geomorphic processes that have been active during the past 10,000 years.

\subsection{Geomorphic surfaces and environments}

\subsubsection{Introduction}

Geomorphic evaluation identified three major geomorphic surfaces within the study area. These surfaces are differentiated according to physical characteristics, apparent age, and types of processes that are active on each of these surfaces. These surfaces are identified in Table 1 as the floodplain, terraces, and bluffs and are further subdivided into depositional environments and/or geologic formations as shown in Table 1 and Figure 2. The approximate age of each surface and the types of geomorphic processes that are active are identified in Table 1. 
Table 1. Geomorphology of the project area.

\begin{tabular}{|c|c|c|c|}
\hline Surface & Landform (Formation) & Age & $\begin{array}{l}\text { Geomorphic } \\
\text { Process }\end{array}$ \\
\hline \multirow{5}{*}{ Floodplain } & Point bar & $\mathrm{H}$ & LA \\
\hline & Backswamp (Hb) & $\mathrm{H}$ & VA-BT-SF \\
\hline & Abandoned course & $\mathrm{H}$ & LA-VA \\
\hline & Abandoned channel & $\mathrm{H}$ & LA-VA \\
\hline & Natural levee & $\mathrm{H}$ & VA-SF \\
\hline \multirow{4}{*}{ Terrace } & Abandoned floodplain (Pi) & $P$ & E-SF \\
\hline & Deweyville terrace $(\mathrm{Pd})$ & $P$ & VA-BT-SF \\
\hline & Prairie terrace $(\mathrm{Pp})$ & $P$ & E-SF \\
\hline & Montgomery terrace $(\mathrm{Pi})$ & $P$ & E-SF \\
\hline \multirow{3}{*}{ Bluffs } & Claiborne group (Tc) & $T$ & E-SF \\
\hline & Wilcox group (Tw) & $T$ & E-SF \\
\hline & Midway group (Tm) & $T$ & E-SF \\
\hline
\end{tabular}

AGE: $\mathrm{H}=$ Holocene, $\mathrm{P}=$ Pleistocene, $\mathrm{T}$ = Tertiary.

PROCESS: VA $=$ Vertical accretion, $\mathrm{LA}=$ Lateral accretion, $\mathrm{BT}=$ Bioturbation, $\mathrm{SF}=$ Soil Forming Processes, $\mathrm{E}=$ Erosion.

Figure 2. Depositional environments of a meandering river.

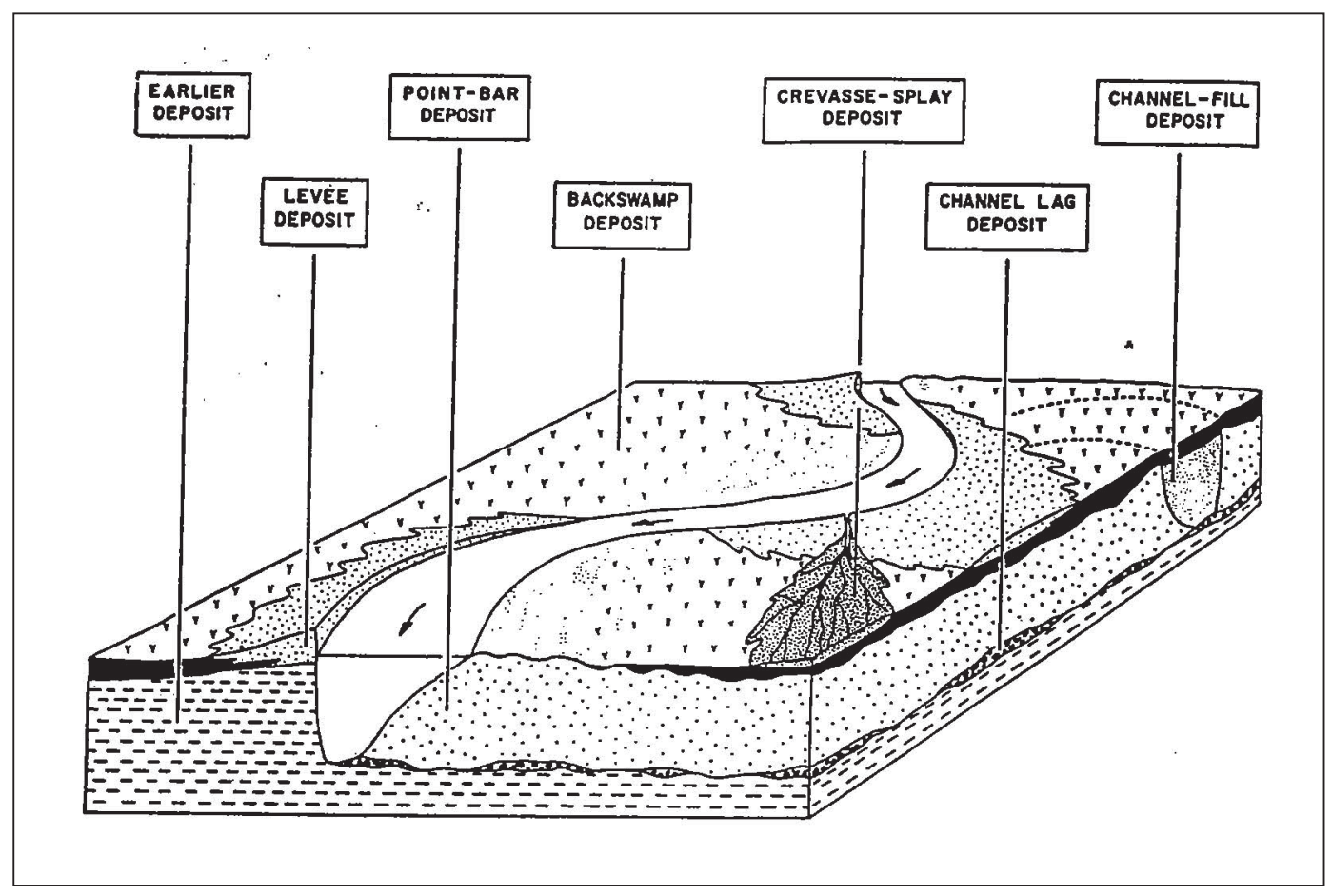




\subsubsection{Bluff slopes and tertiary sediments}

Surface outcrops of Tertiary sediments in the study area are restricted to the bluff slopes and summits. The Tertiary sediments were defined by a sharp break in the topography between the floodplain surface and the bluff slopes. Boundaries separating the Tertiary units are based on Smith and Russ (1974). These Tertiary formations are fluvial-deltaic, near shore, and marine sedimentary sequences. Geologic formations that make up the valley slopes are identified on the geomorphic maps and in Table 1 . The Tertiary Claiborne, Wilcox and Midway groups consist of interbedded deposits of sand, clays, lignitic silts, and lignite. Overlying the Tertiary units in the valleys are Pleistocene and Holocene fluvial sediments.

\subsubsection{Terrace $\mathbf{( P i )}$}

A terrace is an abandoned floodplain surface that is elevated above the present river's floodplain. A terrace consists of a relatively flat or gently inclined surface that is bound on one edge by a steeper descending slope and on the other edge by a steeper ascending slope (Bates and Jackson 1980). Terraces generally border the present floodplain or may be preserved as topographic islands or remnants within the present floodplain. Terraces are differentiated on previous geomorphic maps (Smith and Russ 1974).

In the Red River Valley, five terraces have been differentiated in Texas (Jacobs 1981) and six in Louisiana (Russ 1975). The recognized terraces from Louisiana (Russ 1975; Smith and Russ 1974) nomenclature are (from oldest to youngest) Williana or Citronelle, Bentley, Montgomery, Prairieupper, Prairie-lower, and Deweyville. Pleistocene terraces in the study area were identified as Qtm or Montgomery by Smith and Russ (1974). However, this report uses the revised nomenclature developed by Saucier and Snead (1989) and identified the terraces as Pleistocene intermediate (Pi) terraces. Refer to Table 2 for a Pleistocene Terrace correlation chart. 
Table 2. Pleistocene terrace correlation chart.

\begin{tabular}{|l|l|l|l|}
\hline \multirow{2}{*}{ Fisk (1938) } & $\begin{array}{l}\text { Russ (1975) } \\
\text { Smith and Russ (1974) }\end{array}$ & $\begin{array}{l}\text { Jacobs } \\
\mathbf{( 1 9 8 1 )}\end{array}$ & $\begin{array}{l}\text { Used in this Report Saucier } \\
\text { and Snead (1989) }\end{array}$ \\
\hline \multirow{2}{*}{ Prairie } & Deweyville (Qtd) & T1 & Deweyville Complex (Pd) \\
\cline { 1 - 2 } & Prairie-lower surface (Qtp2) & T2 & Prairie Complex (Pp) \\
\cline { 2 - 3 } Montgomery & Prairie-Upper surface (Qtp1) & & \\
\hline Bentley & Montgomery (Qtm) & T3 & Intermediate Complex (Pi) \\
\hline Williana & Bentley & T4 & Upland Complex (Pu) \\
\hline
\end{tabular}

Terraces mapped in the study area are flat or gently inclined surfaces that occur adjacent to the floodplain. Mapped terraces on the geomorphic maps are interpreted as depositional terraces. In general, the boundary between the terrace and the floodplain was mapped by noting the sharp scarp between the two surfaces. This boundary was then further refined by incorporating soils data from the available county soil survey bulletins, land use interpreted from aerial photography, and site investigations conducted in the field. The Pd surface is at about the same level or buried by the Holocene floodplain. The Pp terrace stands approximately $20 \mathrm{ft}$ (6 m) above the floodplain. The Pi terrace surface stands approximately $40 \mathrm{ft}(12 \mathrm{~m})$ above the floodplain.

\subsection{Floodplain geomorphic environments}

\subsubsection{General}

The following paragraphs describe the physical appearance and processes that form individual types of geomorphic features encountered in the study area. This is a summary of information published in textbooks of geomorphology (e.g., Chorleyet al. 1984) and is included here to make this report more useful to non-geologists.

\subsubsection{Point bar (PB)}

Point bar deposits are lateral accretion deposits formed as a river migrates across its floodplain. River channels migrate across their floodplain by eroding the outside or concave bank and depositing a sand bar on the inside or convex bank (Figures 2 and 3). With time, the convex bar grows in size, and the point bar is developed. Associated with the point bar are a series of arcuate ridges and swales. The ridges are formed by lateral 
channel movement and are relic sandy lateral bars separated by low-lying swales. Swales are locations where fine-grained sediments accumulate.

Point bar deposits are as thick as the total depth of the river that formed them. These deposits are finer graded upward in the deposit from the maximum size of the river's bed load (coarse sand and/or fine gravel) to fine-grained soils (clay) at the surface.

The basal or coarse-grained portion of the point bar sequence (i.e., point bar substratum) is deposited primarily by lateral accretion while the finegrained or upper portion of the point bar sequence (i.e., point bar top stratum) is deposited by overbank vertical accretion.

Figure 3. Schematic and aerial view (from Saucier 1994) of a typical point bar depositional environment.

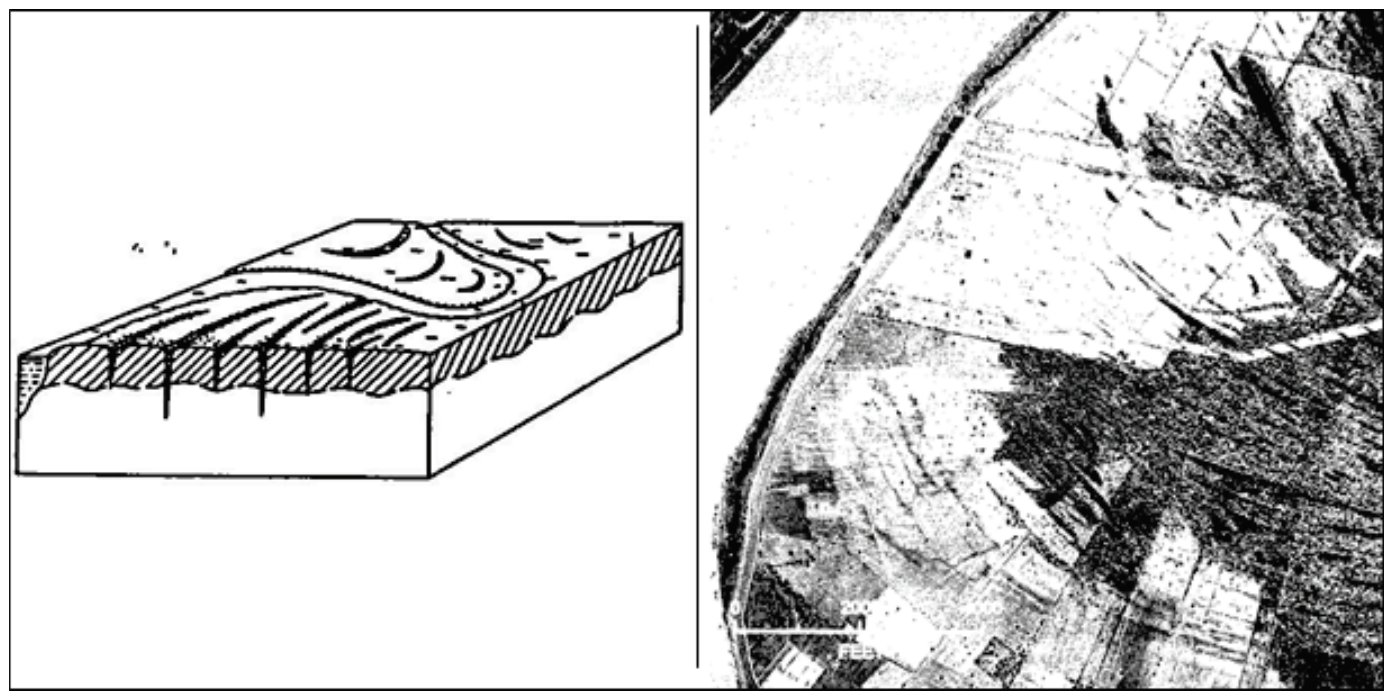

Point bar deposits in the Red River Valley are the dominant and most dynamic environment within the project area. Point bar limits were defined primarily from interpretation of photography and from boring and topographic data. Older point bar deposits are removed from the zone of active lateral accretion and are receiving sediment primarily by vertical accretion.

Primary characteristics of the active point environment are the well developed ridge and swale topography and its proximity to the main channel. In the Red River Valley, ridge and swale topography is especially well developed. Another primary characteristic of the point bar environment is the prominent sandy point bars along the main channel. 
Sandy point bars are easily recognized on aerial photography and topographic maps.

Sediment types defined by borings identify a typical point bar sequence as grading upward from poorly-graded or uniform sands at the base to silty sands, silts, and clays near ground surface. These deposits are usually variable horizontally, especially where ridge and swale topography is well developed or relic chutes (high-water channel across the point bar neck) are present. Older Red River point bar deposits contain a much thicker and finer top stratum.

Boring data indicate that point bar deposits are separated into two distinct units based on sediment types (i.e., a thin predominantly fine-grained upper unit or point bar top stratum (silt and clay) deposited by vertical accretion and a thick coarse-gained lower unit or point bar substratum (silty sand and sand) deposited by lateral accretion). Point bar top-stratum deposits are approximately 15 - to $20-\mathrm{ft}$ ( 5.0 to $7.0 \mathrm{~m}$ ) thick. The substratum, in comparison to the top stratum, is much thicker and forms almost the entire thickness for this environment.

\subsubsection{Natural levee}

Natural levee deposits form by vertical accretion when the river overtops its banks during flood stage and sediment suspended in the flood flow is deposited immediately adjacent to the channel. The resulting landform is a low, wedge-shaped ridge with the greatest thickness adjacent to the river (Figures 2 and 4). Natural levee thickness decreases away from the river until it eventually merges with other floodplain deposits.

Natural levee deposits in the project area are approximately 5- to $20-\mathrm{ft}$ ( 2 to $6 \mathrm{~m}$ ) thick and, along the Red River, may range several miles in width. A reconnaissance investigation identified silt and sand as the predominant soil types associated with natural levee deposits.

Natural levee deposits generally contain a low organic content because oxidation has reduced organic materials to a highly decomposed state. Soils are typically brown to reddish brown. Small calcareous nodules are frequently associated with these deposits as a result of groundwater movement through the permeable levee soils. Natural levee soils are generally well drained and have low water contents and a stiff to very stiff consistency. 
Figure 4. Schematic and aerial view (from Saucier 1994) of a typical natural levee depositional environment.

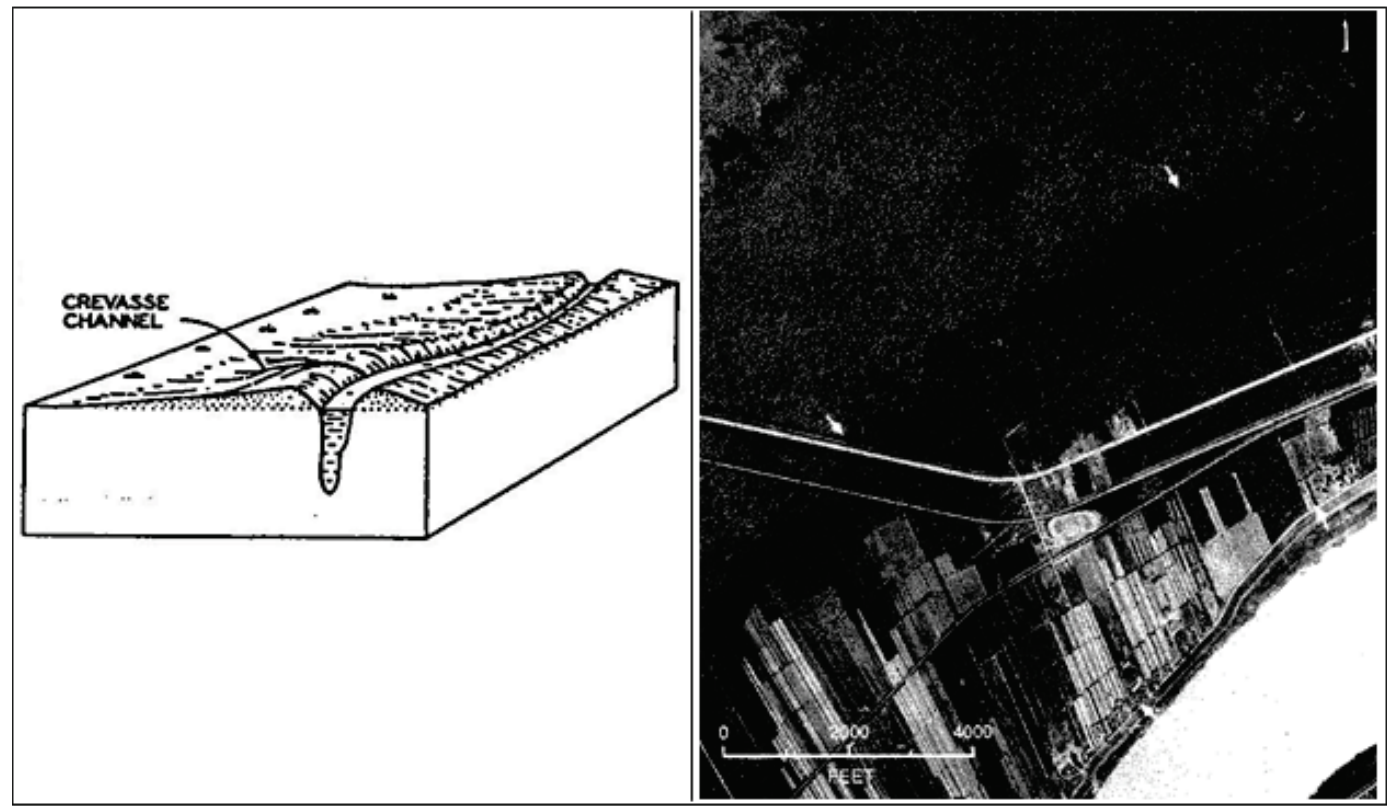

Natural levee deposits were mapped as a separate environment on the geomorphic maps because this environment is present throughout the floodplain to some extent. Natural levee deposits are an important geomorphic process in the study area, especially as a foci for cultural resources. Knowledge about top-stratum thickness is helpful in understanding and evaluating buried archaeological sites.

\subsubsection{Abandoned course}

An abandoned course is a river channel that is abandoned in favor of a more efficient course (Figure 5). A course must contain a minimum of two meander loops for the channel to be classified as an abandoned course on the geomorphic maps. Abandoned courses are abundant throughout the project area. An abandoned course forms when the river's flow path is diverted to a new position on the river's floodplain. This event usually is a gradual process and begins by a break or a crevasse in the river's natural levee during flood stage. The crevasse forms a temporary or crevasse channel that may, over time, develop into a more permanent channel. Eventually, the new channel diverts the majority of flow, and the old channel progressively fills. Final abandonment begins as coarse sediment fills the abandoned channel segment immediately downstream from the point of diversion. Complete filling of the abandoned course is a slow process that occurs first by lateral accretion and then later by overbank deposition and 
vertical accretion. The complete filling process may take several hundred to several thousand years to complete. In some instances, complete filling may not occur as relict and upland drainage preserves partial stream flow through the course.

Figure 5. Schematic and aerial view (from Saucier 1994) of a typical abandoned course depositional environment.

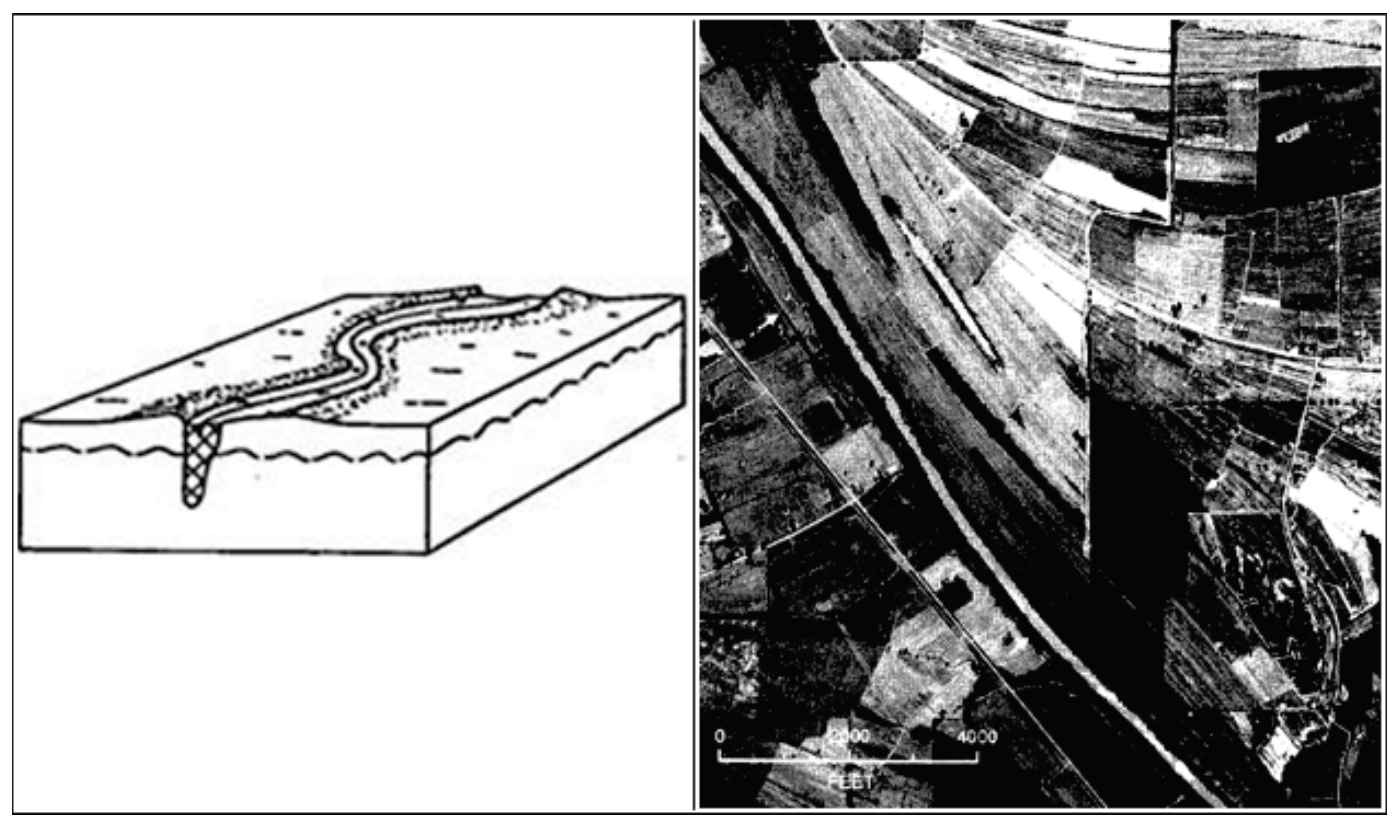

Abandoned courses and associated abandoned channels collectively form a meander belt on the floodplain of the river. Meander belt deposits consist of a several miles wide massive point bar sequence divided by various abandoned channels and courses that collectively form the meander belt. The frequency and location of the meander belt segments, which will be discussed later, are useful for determining the Holocene chronology of floodplain development.

\subsubsection{Abandoned channel}

Abandoned channels are relict channel loops that are abandoned when the river cuts across its point bar (Figures 2 and 6). The cutoff produces an oxbow lake. The process by which the river abandons the loop occurs either gradually as a neck cutoff or during a single flood event as a chute cutoff. A chute is a high-water channel across the point bar of the channel. Abandoned channels mapped by this study may be either well-defined classic oxbow loops or loop segments. Abandoned channels are abundant throughout the project area. 
Figure 6. Schematic and aerial view (from Saucier 1994) of a typical abandoned channel depositional environment.

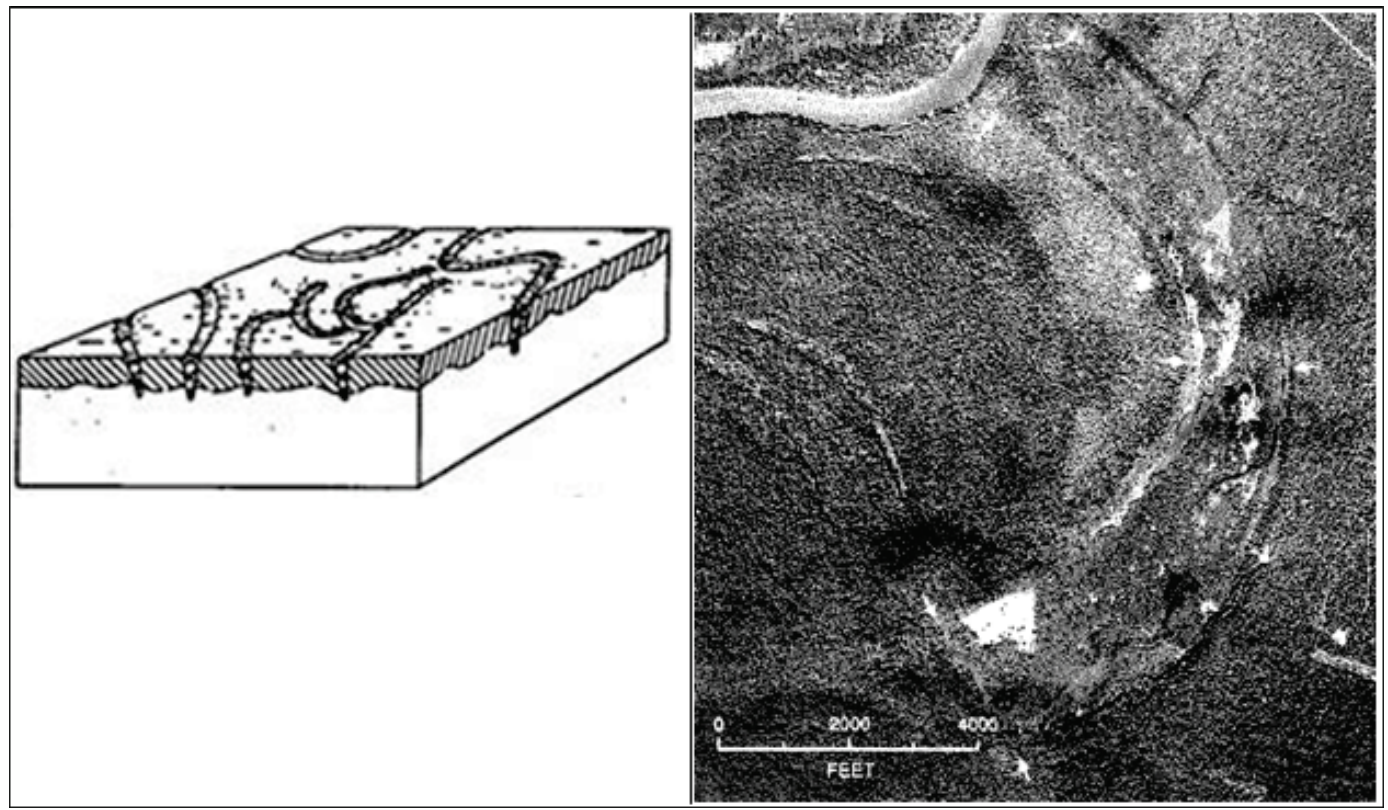

Channel filling is a gradual process. It occurs initially by lateral accretion when the channel is still connected to the main course. After the main channel has migrated away from the abandoned segment, vertical accretion then dominates. During times of high-water flow, suspended sediment is transported to the abandoned channel. Abandoned channels associated with the present meander belt are generally hydraulically connected to the main channel and are still in the process of filling. In contrast, abandoned channels on the older surfaces are filled or almost completely filled. Thickness of channel fills range from 25 to $30 \mathrm{ft}$ ( 8 to $10 \mathrm{~m}$ ). Abandoned channels that are not filled continue to receive sediment by overbank deposition during the peak flood season, which may occur for only a brief time each year.

\subsubsection{Backswamp (BS)}

Backswamp deposits form by periodic flooding and vertical accretion of new sediment. The primary geomorphic process occurring in this environment is vertical accretion of new sediment by annual flooding, pedogenesis, and bioturbation. These processes combine to form a characteristic soil profile and lithology. In general, soil types are predominantly gray to dark red-gray clay interbedded with silt and decayed roots and wood fragments. Backswamp deposits are 20- to $30-\mathrm{ft}$ (6 to $10 \mathrm{~m}$ ) thick. 
Backswamp deposits in the project area are located in poorly drained forested areas bordering the point bar environments (Figures 2 and 7). This environment is approximately 25 percent of the study area. Backswamps are common in the Red River Valley and have been covered with lacustrine deposits.

Figure 7. Schematic and aerial view (from Saucier 1994) of a typical backswamp environment.

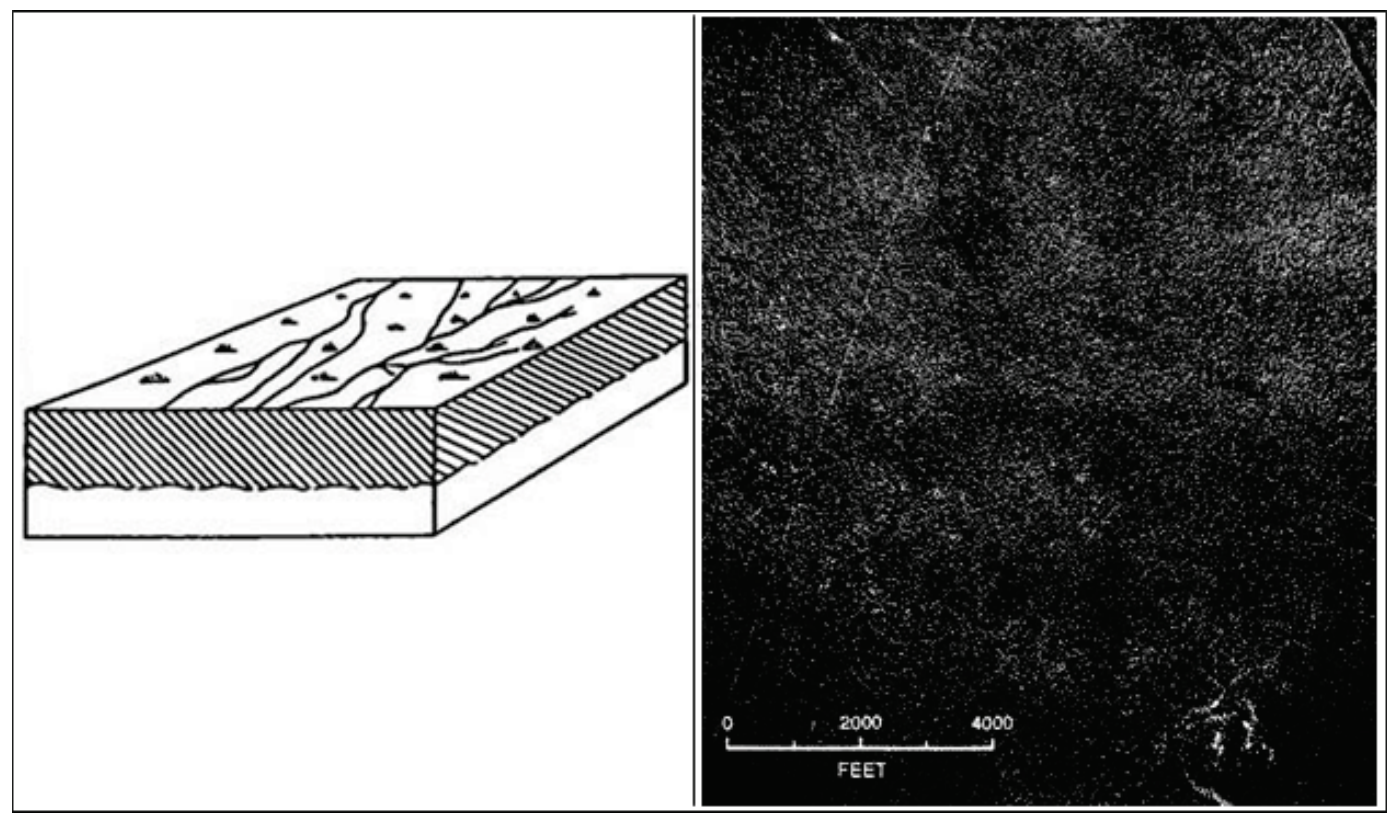

\subsubsection{Alluvial architecture}

The previous sections described the landscape components or geomorphic depositional environments. This section will portray the landform relationship in the subsurface. Twelve cross sections (Plates 1-12 in Appendix B) were compiled from available boring data. Individual plots of the boring data are in Appendix D. The location of each cross section is shown on the geomorphic maps. The horizontal distance in feet represents running distance along the cross section and not levee stationing.

Examination of sections reveals the alluvial sediment incised the Tertiary sediments $(\mathrm{Tu})$. Abandoned channels and point bars are seen in the sections. Backswamps are located away from the active and abandoned channels.

Natural levee deposits drape most of the floodplain. Beneath and within the natural levee deposits is an inferred paleosurface. The paleosurface is a suggested level to explore for covered archeological sites. 


\section{Soil Geomorphology}

\subsection{Introduction}

An important characteristic that distinguishes landforms is the development of a mature soil profile(s) by pedogenic processes. The presence or absence of a soil profile reflects the types of geomorphic processes that are active in the area and the age of the soil sequence (Birkeland 1984). A definite relationship was established during the study between geomorphic surfaces and soil materials. The understanding of the relationship increases the ability to predict location and probability of archaeological sites and pattern of soil genesis on a given surface. Landscape stability is evident by a well-defined soil imprint. Soil data from the soil surveys (Soil Conservation Service (SCS) 1979, 1984) were used to infer the degree of stability of the Red River landforms. Because burial of sites is important to archeological surveys, the recognition of buried soil horizons and surfaces is considered.

\subsection{Soil-forming processes}

Soil-forming processes are governed by the physical properties of the soils, the environmental influences of the geomorphic system, and the duration of the geomorphic processes. Soil genesis on each surface can be viewed as consisting of two steps: (1) the accumulation of parent materials and (2) the differentiation of horizons in the profile (Simonson 1959). The primary parent material in this study is alluvium with colluvium and hillslope sediments being secondary sources. Horizon differentiation in the parent material is a result of four basic kinds of changes occurring throughout the system. According to Simonson (1959), these are additions, removals, transfers, and transformation. Physical properties of the underlying soils and the soil profile are variable because of differences in (a) topography and slope, (b) the types of vegetation that are growing on the surface, (c) the land-use characteristics of the area (e.g., crop land versus timber), (d) variations in climate, (e) composition of the underlying parent materials, and (f) the time involved in which the soil has formed. These variations control the different types of geomorphic and pedogenic processes that are involved in soil formation, and they govern the soil profile that will be developed. Changes are brought about by the effects of the soil-forming factors. 


\subsection{Soil-forming factors}

The five soil-forming factors have been studied and are expressed in Equation 1 by Jenny (1961).

$$
s=f(c l, o, r, p, t \ldots)
$$

where $s$ denotes any soil property. The soil-forming factors in parentheses, mostly groups of factors, are defined as follows.

$$
\begin{aligned}
c l= & \text { climate change } \\
o= & \text { organisms and their frequencies } \\
r= & \text { relief or topography } \\
p= & \text { parent material, defined as state of soil at soil formation time } \\
& \text { zero } \\
t= & \text { age of soil, absolute period of soil formation } \\
\ldots= & \text { additional, unspecified factors. }
\end{aligned}
$$

A discussion of each factor follows.

\subsubsection{Climate}

Climate is considered by many to be the most important factor in the development of soil characteristics. It accounts for the present and historical effects of rainfall, temperature, and wind on soil features. A significant point in considering the effect of climate is its cyclical nature, variance in time, and amounts of inputs.

\subsubsection{Organisms}

The organism factor is composed of the fauna and flora of the region. As with climate, both past and present influences of plants and animals are visible in the present soil. Plants are involved in the initial development of soils through mechanical and chemical weathering. Throughout the succession of a soil, the properties of organic carbon, nitrogen, $\mathrm{pH}$, bulk density, color, and structure are affected by plants. The influence of animal populations can be seen by the mixing brought about by the activities of burrowing species. Grazing species and even man impacts the soil to an extent through cultivation and compaction. 


\subsubsection{Topography}

Topography refers to the surface shape of a landform. It includes the gradient, length and width, slope orientation, and convexity or concavity. It affects soil hydrology, runoff or run-on, erosion or deposition, and in conjunction with climate, vegetation. These attributes govern soil properties, such as clay distribution, depth of weathering, profile development, and organic matter and chemical variance.

\subsubsection{Parent material}

Parent material refers to unconsolidated organic and mineral materials in which soils form (U.S. Department of Agriculture (USDA) 1993). It is the material present when soil genesis is initiated. The nature and original properties of the parent material are important to the development of soil properties. It determines many of the chemical, mineralogical, and physical limits of a soil. It influences the types of clay developed and the structure, texture, color, and natural fertility of soils. These properties in turn create variability in drainage, available moisture, and vegetation.

\subsubsection{Time}

"Time here refers to passage of time...and in itself has no influence on the landscape; rather it records the accomplishments of the system" (Schumm 1977). Time in this context is important only to help establish a starting and stopping point and to compute process rate (Daniels and Hammer 1992). Weathering of the parent material and development of soil features are aligned with time. Parent materials and soil features vary in the amount of time needed to produce soil material. Determining these times for a given parent material or feature to develop can, in some cases, assist in ascertaining relative age. For example, the absence of a soil profile indicates a soil that has been recently deposited and has not had sufficient time to develop a profile.

\subsection{Soil geomorphology}

The soil series will be discussed in terms of the geomorphic position and geoarcheological significance. Each of these different soil series has a unique soil profile characterized by diagnostic physical, and/or chemical properties. The diversity of the soil series for different landforms reflects, in part, differences in mapping conventions between the various counties and differences in soil type due to geography and variations associated 
with the soil forming variables (e.g., time, parent material, climate, biological activity). Because of the great variety of soil series associated with the different landforms, specific or exact relationships between soil series and landform type are not possible. Rather, general soil properties and characteristics can be differentiated for the various landforms.

The study area consists of soil classes, ultisols, alfisols, vertisols, mollisols, inceptisols, and entisols. The Tertiary bluff and slopes consist of ultisols, such as the Bowie, Briley, and Sacul series, and alfisols, such as the McKamie and Muskogee. These soils reflect long-term pedogenesis and, thus, stability. Numerous Archaic sites have been located on Buzzard Bluff. However, the fact that ultisols are poor agriculture soils may explain the lack of Caddo sites.

Other alfisols are the Rilla, which are associated with natural levee deposits of former Red River channels. The Rilla reflects natural levee deposition along portions of Finn Bayou and Red Chute. The soil profile in a typical Rilla silt loam is an argillic horizon at $1.2 \mathrm{ft}(0.35 \mathrm{~m})$.

Vertisols, such as the Billyhaw series, are developed on backswamp surfaces. Another clay soil associated with backswamps is the Perry. The Perry clay is an inceptisol reflecting weak soil profile development. The profile of Perry clay reveals a buried B horizon at $1.75 \mathrm{ft}(0.5 \mathrm{~m})$. The Billyhaw and Perry clay are associated with the Finn Bayou Meander belt (Heinrich 1993). The clay veneer masked the meander belt features and probably a buried site associated with settlement along the Finn Bayou course.

Other soils have mollic epidons and are classified as mollisols, such as the Latanier and Caspiana. Discussions with Louisiana SCS staff suggest that the organic enrichment of these mollisols is possibly associated with the Great Raft, which accelerated organic and overbank deposition in the Red River Valley. The Caspiana is found on the flanks or distal portions of natural levees. The soil profile of the Caspiana shows a discontinuity at $2.2 \mathrm{ft}(0.66 \mathrm{~m})$. The Latanier contains a contrasting texture at approximately $3.3 \mathrm{ft}(1 \mathrm{~m})$.

Entisols exhibit the least amount of soil development and are, therefore, considered the most recent in age. Included in the entisol class are the Severn silt loam, Kiomatia loamy fine sand, and Oklared fine sandy loam. 
The Severn is associated with a natural levee while the Kiomatia and Oklared series seem associated with historic and modern meander point bars. The Severn's profile reflects cumulative sedimentation with outfaced pedogenisis. Lithologic and color discontinuities at approximately $0.75 \mathrm{ft}$ $(0.25 \mathrm{~m})$ indicate a possible buried surface in the Severn. The Kiomatia also reflects a change in deposition but deeper at $4 \mathrm{ft}(1.3 \mathrm{~m})$. The Oklared's profile reveals a depositional break at $3.8 \mathrm{ft}(1.2 \mathrm{~m})$. Considering the lack of soil development and, thus, relative recent age of these soils, only historic and proto-historic sites are possible.

\subsection{Soil summary}

The principal soil geomorphic processes are vertical accretion of new sediment from annual flooding, pedogenesis (soil formation), and bioturbation. These processes combine to produce a characteristic soil profile and lithology in each landform. In general, soil profiles are better developed in older deposits than in the active point bar setting. Classification of soils by SCS indicates that inceptisols, mollisols, and alfisols are the major soil groups for the older surface, while entisols are associated with the younger environment. The geomorphic importance associated with both argillic and mollic soil horizons in the Finn Bayou area is that these soil horizons represent a stable surface and require a certain amount of time to develop. Exactly how much time is needed to develop either of these characteristics is unknown as it relates to the complex interchange between the different soil forming variables. Geomorphic significance of soil horizons in terms of this study is that the Finn Bayou surfaces have been stable long enough for pedogenic processes to imprint and alter the underlying fluvial deposits. 


\section{Geomorphic Chronology}

\subsection{Introduction}

Another objective of this study was to define the geomorphic chronology of the project area to the extent possible with the known data. The chronology is based on the available soils and geological data, results of the geomorphic mapping, borings (Appendix D), radiometric age (Appendix E) data from this study, and comparisons of archeological site records. The geomorphic history of the area is defined by the distribution and extent of the underlying geologic units, the floodplain sediments that overlie these formations, and the soils that have formed and modified these different landscape elements.

\subsection{Pleistocene}

The Red River was not directly affected by continental glaciation during the Pleistocene. Therefore, the fluvial system did not directly receive glacial melt water or related sediments. Instead, geomorphic processes operating in the study area were controlled by climatic variations associated with Pleistocene glaciation. Climatic changes influenced the base level on the Red River and its tributaries. Because the outlet for the Red River during the latter part of the Pleistocene was by way of the Mississippi River Valley, indirect effects of glaciation (i.e., glacial melt water, glacial sediment, and sea level changes) would have influenced the Red River's discharge to the Mississippi River and its link to the Gulf of Mexico. The end result of this complex interchange between Pleistocene climate changes and associated base level response has been the creation and incision of a well-defined drainage basin into the underlying Tertiary sediments. At the beginning of the Holocene, the Red River alluvial valley and its larger tributaries had developed a series of descending stepped terraces that were formed as a result of both aggrading and degrading fluvial cycles and a well-defined floodplain with associated environments of deposition. Within the boundaries of the study area, the mapped terraces are the Pleistocene Deweyville (Pd), Praire (Pp), Montgomery (Pm), and Intermediate (Pi) (Saucier and Snead 1989).

\subsection{Holocene}

During the Holocene, the Mississippi River built five meander belt courses in its alluvial valley (Saucier 1974; Saucier and Snead 1989). In the Red 
River Valley, six remnant meander belts are preserved (Smith and Russ 1974; Russ 1975; Saucier 1974; and Saucier and Snead 1989). The most recent Red River course to the Mississippi River may have formed sometime between 500 and 1,000 years BP through Moncla Gap (Russ 1975). Pearson (1986) suggested this change may have occurred even earlier, perhaps as early as 1,800 years $\mathrm{BP}$ based on archaeological data. Hall (1990) indicates that approximately 1,000 years BP, a regional climate change occurred from moist to dry in the southern Great Plains. The response by the Red River to this climate change may have led to channel incision that helped to promote increased bank erosion. Floodplain incision, bank erosion, and valley-wide lateral migration may have introduced a large influx of sediment and trees into the lower Red River Valley to form the Red River Raft.

Saucier and Snead (1989) compiled previous mappings of the Lower Mississippi Valley and its tributaries. This synoptic view of the region indicates two meander belt deposits (i.e., Hrm1 and Hrm2). These meander belts are the youngest two of the six recognized belts (Saucier and Snead 1989). A preliminary geomorphic study relating the distribution of prehistory archaeological records was conducted by Pearson (1982). The work is part of a multi-hypothesis in the valley's evolution and prehistoric landscape adaption. Pearson infers three meander belts: modern, intermediate age, and older belts.

\subsubsection{Older meander belt (Hrm2)}

Saucier and Snead (1989) mapped the Finn Bayou abandoned channels and course as Hrm2. The age of the Finn Bayou meander belt (Pearson 1982 ) is tentative but is associated with Pearson's older meander projected to be older than 3,000 years BP. A radiometric date of $4610 \pm 60$ years BP was recorded from a Hrm2 overbank deposit (Appendix E). Archaeological data indicate Late Archaic (5,000 to 2,500 BP) and Fourche Maline $(2,500$ to 1,000 BP) sites adjacent to Finn Bayou. Based on Jacobs (1981), Heinrich (1993) suggested that Hrm2 could have flowed from 4,000 to 6,000 years BP. Until additional investigations produce radiometric dates, the presumed dates are plausible. The geomorphic features along Hrm2 are mixed with overbank clay deposits. It is inferred that the effect of the Great Raft added additional vertical accretion deposits. Archeological sites are expected to be buried along this meander belt. 


\subsubsection{Intermediate meander belt (Hrm1.1 and 1.2)}

Pearson's (1982) intermediate belt is part of Saucier and Snead's Hrm1. Geomorphic analysis during this study concurs that, based on oxbow filling, the Hrm1 can be differentiated into Hrm1.1 and Hrm1.2. Pearson's (1982) chronology suggests that the intermediate belt was formed 200 to 2,000 years BP. Additional data for this study suggest that the age of Hrm1.2 is 4,000 to 1,200 years B.P. Hrm1.1 is tentatively estimated at 1,200 to 200 years B.P. Hrm1.2 oxbows are recognized by their partial filling. The Hrm1.2 abandoned channels usually are flooded part of year and contain cypress swamps. Pearson (1982) included Red Lake on the eastern valley wall as part of the intermediate belt. An alternative hypothesis is that Red Lake and other eastern wall abandoned channels could be remnants of a Little River meander flowing during the time of Hrm2 deposition.

\subsubsection{Modern meander belt (Hrm1.0)}

The modern meander belt has been active for the last 200 years (Pearson 1982). Review of historic maps shows the present meander belt to be active. For example, Old River Lake, Adam's Cut-off, and First Old River Lake were part of the channel in the 1840s. Willow Lake and Scott Lake were abandoned before 1840 . The oxbow lakes or abandoned channels in Hrm1.0 are open with only partial filling. Examination of the Fulton Quadrangle topographic map also reveals the active meandering of the Red River. For example, the Miller County-Hempstead County line represents the 1876 channel. Even comparison of the 1951 quadrangle to the photo-revised 1970 and 1975 maps shows areas of 2,000 ft migration in approximately 20 years. Thus, the modern meander belt is not likely to contain prehistoric sites.

\subsection{Historic}

By the early 1800 , the lower Red River was blocked by a series of log jams known as the Great Raft or the Red River Raft. The southern portion of the study area was affected by the Red River Raft. The Red River Raft was a series of log jams nearly 100 miles long that had accumulated on the point bars of the river and formed numerous interconnected river channels in the upper Red River Valley (Figure 8). An account of rafting described by Flint (1833) is presented in Smith (1982). 
Figure 8. An artist's conception of the Great Raft. Note the overflow anabranch and distributary channels (Veatch 1906).

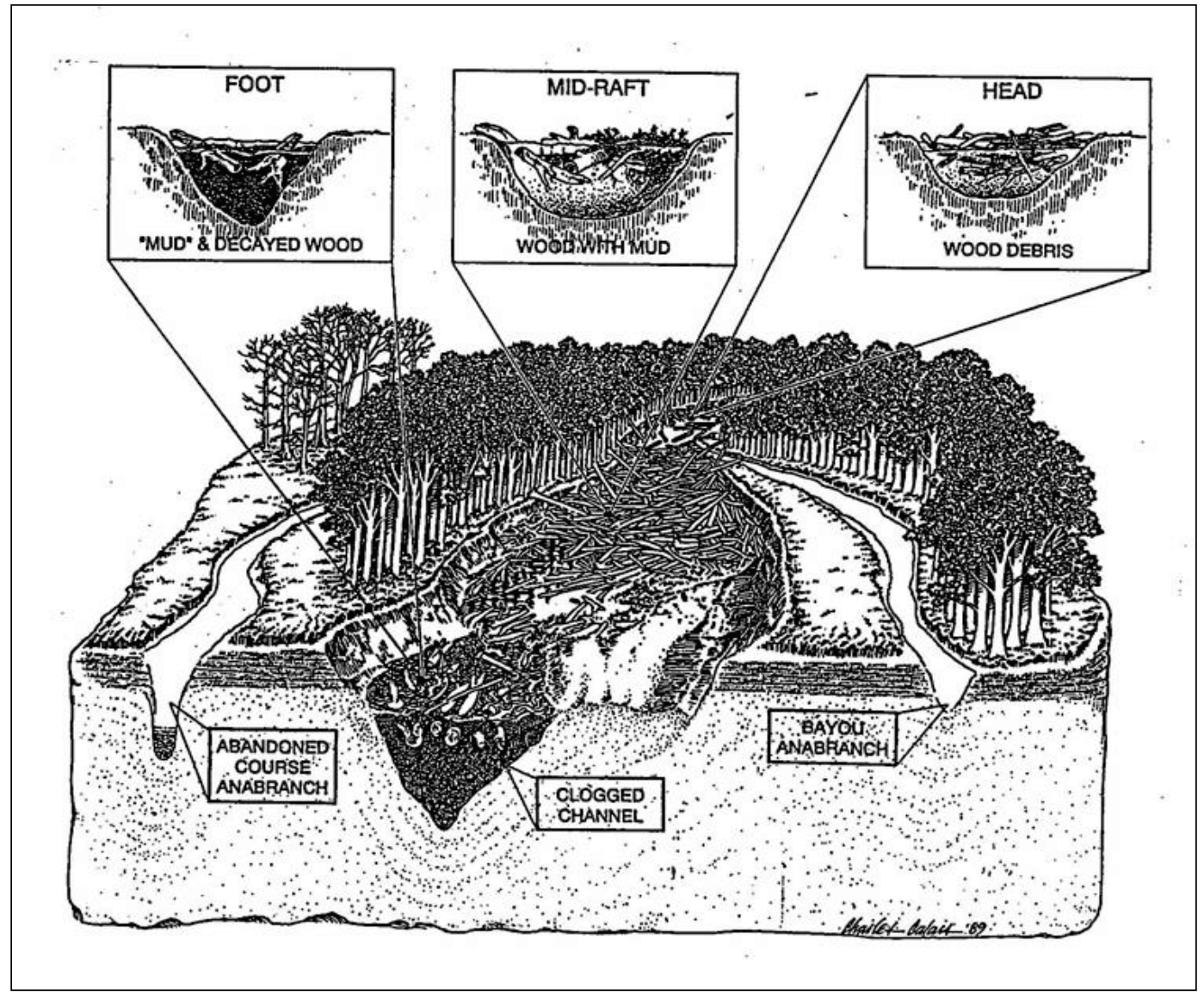

The Red River Raft led to the formation of numerous valley margin lakes within the Red River Valley and alluvial valleys of its tributaries (Flint 1833). The raft was an important mechanism for the formation of the large lakes that covered the southern part of the study area during historic time. This study will not consider the history of the raft other than its significance to lake formation as it is beyond the scope of this investigation. Further information about the raft is available from numerous historic accounts and papers (Darby 1816; Flint 1833; Veatch 1906; Caldwell 1941; and Mills 1978).

Poston Lake covered much of the lower study area by the early 1800 as shown by Figure 9 (Veatch 1906). It is judged that the maximum lake limits for Poston Lake were established during historic time, near the levels indicated by Figure 9. Beneath the limits of raft lakes, lacustrine deposits buried the former floodplain of the Red River. The thickness of these lacustrine sediments was identified as approximately $3.2 \mathrm{ft}(0.98 \mathrm{~m})$ (Albertson and Dunbar 1993). Lacustrine deposits may be even thicker, depending on distance from sediment source areas. 
Figure 9. Location and limits of Poston Lake (Veatch 1906).

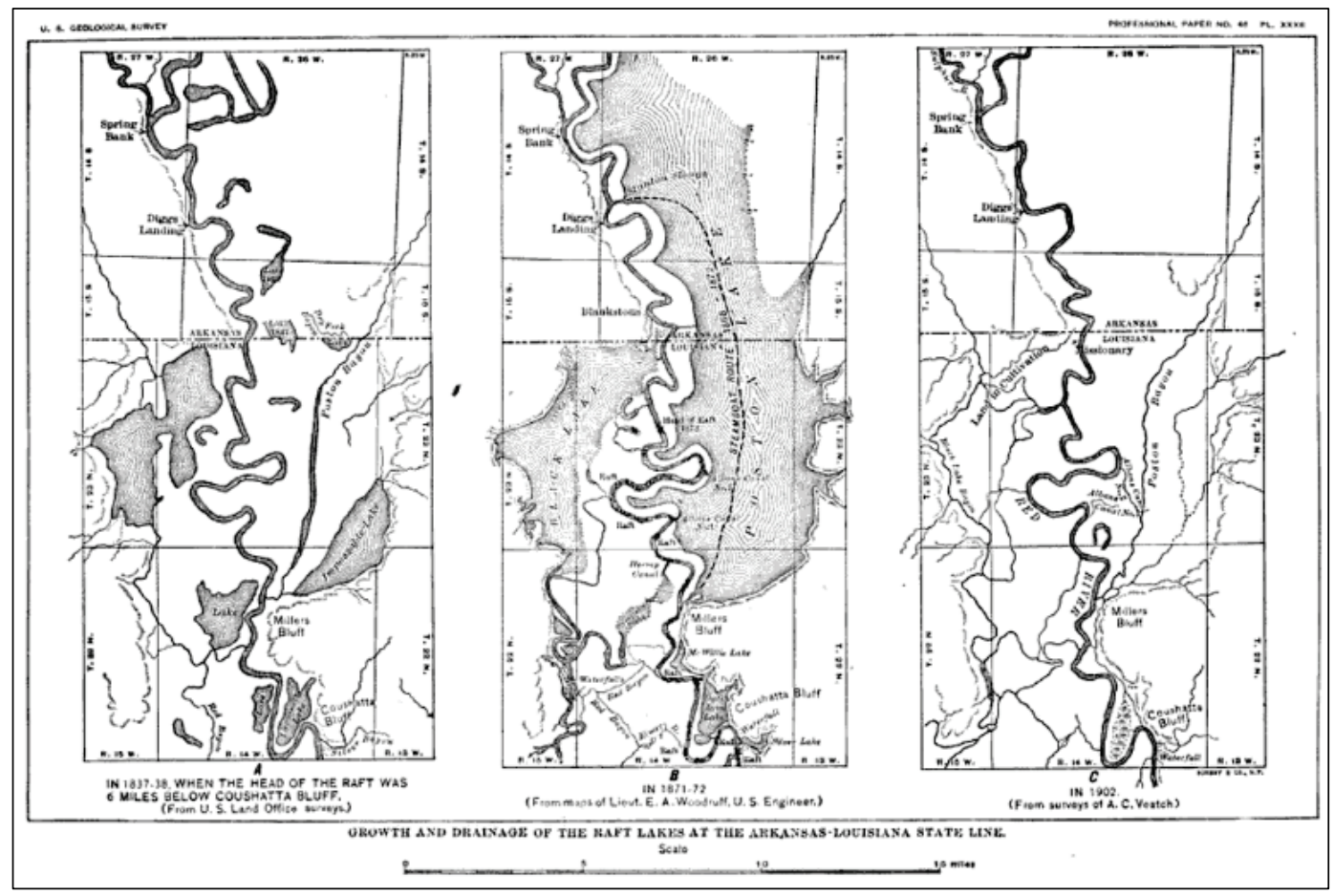

After 40 years of intermittent action, removal of the Great Raft was completed in 1873 by USACE to make the Red River navigable. Removal of the Great Raft caused the Red River to degrade its channel headward and drained the large lakes, such as Poston Lake that had formed behind the raft (Figure 9).

Formation of raft lakes would have flooded the existing floodplain. The Hrm2 former floodplain with its abandoned courses and channels would have been buried and masked with a veneer of lacustrine sediments. Therefore, this study suggests that existing archaeological sites would have been buried by lake formation, where they are present.

\subsection{Geomorphic mapping and chronology}

A geomorphic map was prepared to reflect the geomorphic chronology. The Holocene map units follow the general designations of Saucier and Snead (1989) and Pearson (1982) with the addition of detail appropriate to 1:24,000 floodplain mapping for geoarchaeological site prediction. The Holocene floodplain consists of Red River meander belts (Hrm), natural levees (Hrl), and backswamps (Hb). Two meander belts Hrm1 and Hrm2 are identified (Saucier and Snead 1989). Modifying Pearson's (1982) model, subunits of Hrm1 are delineated as Hrm1.o, Hrm1.1, and 1.2. The 
abandoned Hrm2 has surficial expression but is covered by a mappable thickness of abandonment phase backswamp clay. The Little River also produced two meander belts (Hlm) and associated natural levees (Hll). Pleistocene deposits Pm (Pd, Pp, and Pi) and Tertiary Groups (Tc, Tw, and $\mathrm{Tm})$ are delineated but not investigated during this project.

\subsection{Geomorphic mapping units}

HRm. Present and former channel and point bar deposits of Red River meander belts. Surficial deposits range from fine sand to silt loam to clay depending on landscape position in the meander belt topography. Meander belt deposits may be veneered by fine-grained overbank deposits of natural levee, channel fill, swale fill, and backswamp origin. Multiple meander belts are identified. Meander Belt 1 has discrete subunits 1.o, 1.1, and 1.2 with locally mappable cross-cutting or accretionary phases. Hrm2 is covered by backswamp clay.

HRl. Natural levee deposits of the Red River associated with overbank deposition near channels. Local crevasse splay and crevasse channel deposits are included within the unit. Sediment textures range from sandy and silty adjacent to channels and grade to silty and clayey in distal areas. Natural levees are locally associated with Meander Belt 1 subunits.

Hb. Backswamp sediments deposited in distal areas of the Red River floodplain. Sediments range from clay to silty clay loam.

HRcc. Crevasse channel deposits of major prominent flood basin channels. Sediment texture ranges from sandy to silty.

HRcl. Natural levee associated with crevasse channels (Hcc). Sediment texture is silty to clayey.

Haf. Alluvial fans associated with small tributaries along the valley wall. Sediment texture varies with sediment supply of the tributary basin.

HLm. Present and former meander belt deposits of the Little River.

HSm. Present and former meander belt deposits of the Sulphur River.

Hu. Undifferentiated alluvium of small streams. 
HLm. Present and former meander belt deposits of the Little River. Surficial deposits range from fine sand to silt loam to clay depending on landscape position in the meander belt topography. Meander belt deposits may be veneered by fine-grained overbank deposits. Two meander belts are identified.

Pm. Pleistocene Montgomery Terrace

Pd. Pleistocene Deweyville Complex

Pp. Pleistocene Prairie Complex

Pi. Pleistocene Intermediate Complex

Tc. Tertiary Claiborne Group

Tw. Tertiary Wilcox Group

Tm. Tertiary Midway Group 


\section{Significance of Geomorphology to Cultural Resources}

\subsection{Introduction}

The most important objective of this study was to determine the archaeological significance of the geomorphic features, especially in terms of locating previously undiscovered sites. The major goals of this objective are to identify and define the principal archaeological site/landform associations and to classify the landforms according to their site potential, provide guidance for locating sites that are of specific ages or cultural components, and identify areas that have high potential for site destruction or preservation by natural geomorphic processes.

The approach that was used to define the relationships between known archaeological sites and geomorphic features involved identifying the known archaeological sites, evaluating geomorphic site data from the recorded sites, and identifying important characteristics that relate the archaeological sites to geomorphic features. These characteristics were then evaluated to predict locations of undiscovered sites according to their geomorphic context.

It is important to emphasize that the primary purpose of this analysis was to show general relationships between the various landforms that comprise the study area and archaeological sites contained within this area. This study was not meant to be an archaeological analysis but rather to reveal trends of geoarcheologic preservation.

\subsection{Procedure}

Archaeological site data were obtained from the Vicksburg District's Environmental Resources Branch, Coastal Environments Inc., and published reports for the Arkansas Archeological Survey. There are 324 known archaeological sites in the Great Bend region. The database of all known sites includes characteristics that were compiled from the geomorphic maps and site descriptions. These characteristics are site number, site name, quadrangle map, cultural components, diagnostic artifacts, site description type (e.g., surface scatter, ceramics, historic debris), and size. Because of their sensitivity, the locations for the known archeological sites are not individually identified on the geomorphic maps. 
Site locations, along with the previous characteristics, were entered into a GIS database for analysis. Using overlay comparisons, relationship of sites to landforms and meander belts were analyzed spatially and temporally by cultural component. The GIS analysis treats sites that occur on two or more landforms as two or more sites.

\subsubsection{Use of GIS in cultural resource assessment}

A GIS is a powerful tool used to manage and manipulate geographically referenced data and information. Software and hardware GIS packages vary in analytical capabilities and database structure. The decision of which one to use is based on the type and amount of data, the desired product, and the GIS format. To construct the Red River GIS and database, ARC/INFO 7.0.2 developed by the Environmental Systems Research Institute (ESRI 1994) was used. The interchangeable format between ARC/INFO Unix and ARC/INFO PC was considered essential in view of the fact that the GIS will be used as a management tool.

The framework for the GIS consists of various coverages that can best supply answers to proposed queries. Coverages refer to a GIS map and represent only one of them. Each theme must be assigned attributes or information that pertains to a particular feature. For example, an archeological site is digitized into the database as a polygon. Attributes, such as cultural affiliation, occupation, and chronology, can then be assigned to form a data structure. Until this information is added, the coverage has little value in the GIS.

The intent of the GIS is to provide support both in interpretation and maintenance of pertinent data concerning cultural resource assessment. The major analysis technique will be the combination or linkage of data layers to analyze or display spatial queries. For example, archeological sites, elevation, and geomorphology may be combined to locate sites situated on a selected landform occurring at a determined elevation. Predictive modeling based on established facts can then aid in future cultural resource investigations and management. By understanding the environment (e.g., geology, geomorphology, and soils of known sites), the GIS is able to locate potential areas containing these same parameters.

Data in the GIS exist in either raster or vector format. Raster data are cellular data structures composed of rows and columns, whereas vector data are coordinate-based data structure used to represent linear map 
features. In raster data, attributes are associated with each grid cell, but in vector data, attributes are assigned to each feature. Both played an important role in construction of the Red River GIS.

The following is a list of digital databases assembled for the project.

- Raster maps

○ Topography

○ Aerial photography

- Vector maps

- Geomorphology

○ Geology

- Soils

○ Elevation

○ Levees

- Archeological sites

○ Geochronology

○ Borings

- Surface water

The GIS can be queried based on attributes assigned to these coverages and linkage between the coverages. When planning a GIS, the purpose of the project supports the queries and is considered when constructing a GIS. It is possible, however, that future projects may require additional information to support different objectives. Additional attributes for existing coverages can be added or new links between coverages can be established. New coverages can also be added, if needed. The following questions are just a few examples the Red River GIS is capable of answering at this time.

- On what type of landform is a particular archeological site situated?

- What is the minimum or maximum elevation of an archeological site?

- What is the lithology of a particular geologic formation?

- What is the chronology and area of a particular archeological site?

- What percentage of archeological sites is situated a given distance from a levee?

\subsubsection{Data requirements for cultural resource assessment}

Many factors contribute to preservation or destruction of archeological sites, and each must be considered for proper management of these 
resources. Fortunately, the scope of the project included field interpretation as well as analyses from available data. An initial reconnaissance of the study area showed that the management system should be based on geomorphology, geology, soils, elevation, levees, and mapped archeological sites. Interpretation of both aerial photography and further field investigations provided verification of previous data. In the following paragraphs, these data are discussed in terms of their source and characteristics.

\subsubsection{Geomorphology}

Field investigations and aerial photography provided the interpretation for the geomorphology theme. A soil auger was used to retrieve samples at various depths throughout the study area. Sampling locations were chosen to confirm previous interpretations and to clarify conflicting analyses. A boring $\log$ was then constructed from soil sample descriptions. Each feature was digitized as a separate polygon and then assigned attributes. Previous geomorphological mapping by Smith and Russ (1974) and existing boring data were considered in this interpretation. Geomorphologic interpretation was discussed in Chapter 3.

\subsubsection{Geology}

The 1:62,500 scale map was scanned using a Tangent Drum Scanner to ensure a more accurate digitization of features. Geologic age, formation name, and feature type were included in the data structure.

\subsubsection{Soils}

Soil information was taken directly from existing 1:20,000 county soil maps generated by the USDA Soil Conservation Service $(1984,1979)$ for Miller and Hempstead counties. Soil information was referenced using the Red River course from the topographic map, discussed later, to provide an accurate overlay of this map to other coverages.

\subsubsection{Elevation}

Elevation was digitized from the $7 \cdot 5$-min $(1: 24,000)$ USGS topographic quadrangles. The area covered by the terrace (Pi) was not considered essential in the interpretations and, therefore, was not included in the data. 


\subsubsection{Levees}

The levees were included in the database as a significant feature. In addition, a buffer reflecting the right-a-way was included. In this way, project specific queries relating to engineering impacts can be made.

\subsubsection{Archeological sites}

Coastal Environments Inc. provided location and descriptive data on archeological sites in the southern portion of the quadrangle. Additional locations can be added to the database as they are acquired.

\subsubsection{Archaeological site definition}

An archaeological site was defined as a location where artifacts have been found. This definition of a site does not differentiate sites of settlements. That is, a site can be a location where settlement has occurred, or it can be a location that was occupied only once and artifacts were left. This nonrestrictive definition is used because of the nature of archaeological site data. For some sites, exact locations or other important information in the site descriptions are missing, or the data are wrong. In addition, it is possible for a single large site to be represented in the record as multiple sites that were recorded at different times by different individuals or organizations.

The primary objective of using the archaeological site data is to show the general relationships between the prehistoric sites and the landforms. It will be left to the archaeologists to interpret information about the site beyond its geomorphic characteristics. It is important to emphasize that the site catalogue has not been field checked. Basic trends are defined about the landforms by the archaeological site data in this section of the report.

\subsubsection{Characteristics of an archaeological site}

Artifacts that make up the archaeological site have by their distribution and position within the site certain temporal and spatial qualities. These qualities are defined by geographic, stratigraphic, and ethnographic characteristics of the artifacts (Gould 1987).

Both the stratigraphic and geographic characteristics describe physical qualities about the site itself. Geographic characteristics describe the spatial context between artifacts and their relationships to other artifacts 
and their environment. Stratigraphic characteristics define the temporal or chronological order of the artifacts and relate these characteristics to the site occupation. Defining the geomorphic setting of the site is an important first step in evaluating geographic and stratigraphic characteristics of the site.

This study describes mainly the geographic (environmental or geomorphic) characteristics of the known archaeological sites. The identification of the site geomorphology is important to understanding the overall site archaeology because different landforms are dominated by certain types of geomorphic processes. These different kinds of processes will affect or control the distribution of archaeological sites and associated artifacts.

Neither stratigraphic nor chronological characteristics of individual archaeological sites were fully addressed by this study. The geomorphic analysis in this investigation will provide a general stratigraphic or chronological framework to evaluate the individual sites. A more detailed evaluation of individual sites will require the acquisition and analysis of further soil borings from the landforms on which individual sites are located. Soil borings will identify important sedimentological and soil forming characteristics and may provide datable materials for further determining chronological boundaries.

The last major criterion of an archaeological site is the ethnographic characteristics. These characteristics are determined by the archaeologist. The ethnographic characteristics of the artifacts and the site are concerned with human qualities of the site. Ethnographic characteristics relate human occupation to their associated activities and to the different types of cultures. However, before ethnographic characteristics can be fully understood, the geographic and stratigraphic characteristics must be fully defined and evaluated.

\subsection{Distribution of known archaeological sites}

\subsubsection{Landforms}

The distribution of prehistoric sites as a function of the different landforms in the study area on which the sites are located is presented in Figure 10. Approximately 6 percent of the known archeological sites are located above the floodplain on valley slopes or bluffs. The remaining 94 percent of the sites is associated with the floodplain of the various 
fluvial components that form the study area. Forty-six percent of floodplain sites are located adjacent to crevasse channels. Other known archaeological sites are primarily located upon natural levee or point bars adjacent to the Hrm1.1 and Hrm1.2 channels or on the Hrm2 surface. Additional sites on the Hrm2 surface in this river reach may be buried by vertical accretion of sediment.

Figure 10. Distribution of archaeological sites by landform.

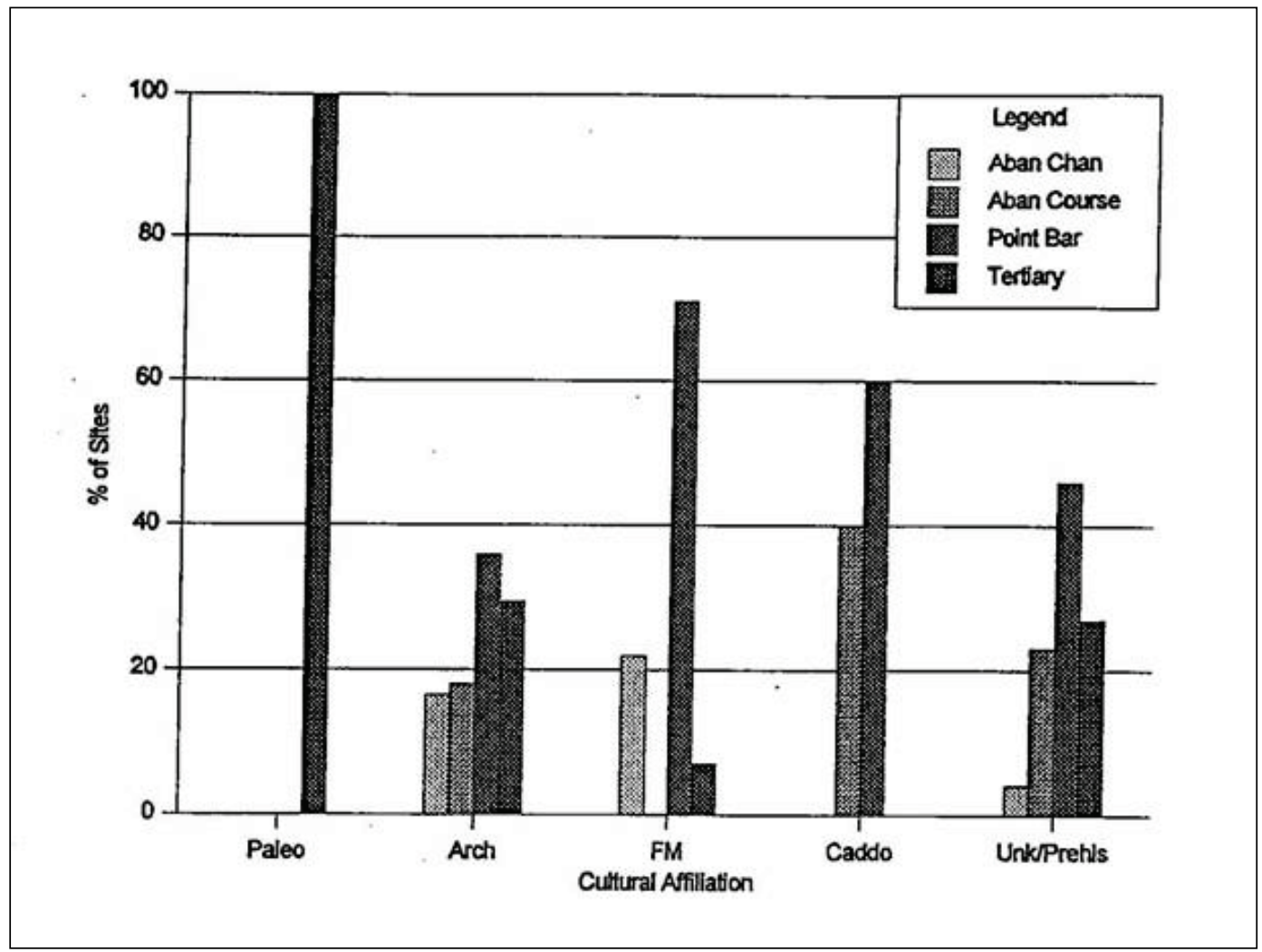

\subsubsection{Distribution of cultural components}

Available archaeological site data for the purpose of this study were divided into cultural component types (i.e., Paleo, Archaic, Fourche Maline, and Caddo). Figure 10 displays the distribution of the culture component across the landscape. Historic sites were not evaluated in this study as prehistoric sites are the primary focus of this investigation and because other factors may govern the distribution and occurrence of historic sites. Historic sites are best defined and evaluated by conducting a detailed historic assessment and inventory of the study area. The Caddo culture ranges from approximately 1,000 to 150 years BP, and Fourche Maline culture ranged from 2,500 to 1,000 years BP. Archaic sites in the southeastern United States generally range from approximately 9,000 to 
2,500 years BP, and Paleo-Indian sites are older than 9,00o years BP. The table in Appendix $\mathrm{C}$ indicates that some sites contain multiple occupations. Sites that are identified as multiple occupations (i.e., Paleo, Archaic, Fourche Maine, and/or a Caddo) are located along Finn Bayou and Red Chute (Hrm2).

\subsubsection{Paleo sites}

Four sites contain Paleo-Indian artifacts. These sites are located primarily on Buzzard Bluff (Tw). Three Paleo-Indian sites are located on Tertiary deposits (Figure 10), and the other is located along a crevasse channel.

\subsubsection{Archaic sites}

One hundred eighty sites or 55 percent of the sites in the GIS contained Archaic artifacts. Approximately 8 percent of the known Archaic sites are located on the summit or slopes (Figure 10). The remaining sites (92 percent) are located on the floodplain. Archaic sites are primarily found on crevasse channels (Hcc) and the Hrm2 meander belt. Apparently, the entire landscape was used by the Archaic cultures. Additional archaic sites may be concealed in the older floodplain (Hrm2) from burial by vertical accretion.

\subsubsection{Fourche Maline sites}

One hundred fifteen of the known sites or 35 percent of the sites in the GIS contained Fourche Maline artifacts. Fourche Maline sites (5 percent) have been located on Tertiary units. The other 95 percent of sites are primarily located on the floodplain. Sixty percent are along meander belts: Hrm2 (8 percent), Hrm1.2 (30 percent) and Hrm1.1 (22 percent). Other sites are located along crevasse channels (31 percent) (Figure 10). Fourche Maline culture seems to have habituated across the landscape, using both upland and floodplain sites. It is likely that additional sites exist beneath the vertical accretion deposits. For example, a Fourche Maline site (3LA25) was buried $1.5 \mathrm{~m}$ (Schambach 1982).

\subsubsection{Caddo sites}

One hundred twenty-four known sites or 38 percent of the sites in the GIS contain Caddo culture components. The sites located along Hrm1.2 meander belt features comprise 45 percent. Caddo sites are located along 
Hrm1.2 and comprise 33 percent in the Great Bend region. Late Caddo sites also exist along the modern meander belt Hrm1.o (Pearson 1982).

\subsection{Prediction of site occurrence}

The distribution of the known archaeological sites as identified in the preceding illustrations indicates that sites are not random but are clearly associated with specific landforms in the project area. Geomorphic relationships identified for the known sites can be used to locate and interpret previously undiscovered sites and guide the subsequent archaeological analysis of the individual sites and the entire study area. Geomorphic relationships identified by this study should help to improve the efficiency of later cultural resource investigations in the project area and maximize the results obtained. In addition to locating undiscovered sites, geomorphic relationships will aid the archaeologist in defining the ethnographic site characteristics. Considering the distribution of known sites, the expected distribution of sites is presented in Table 3.

Table 3. Expected distribution of cultural resources by meander belts.

\begin{tabular}{|l|l|l|l|}
\hline Map unit & Surface culture & Buried culture, $<2 \mathbf{m}$ & Buried culture, $>\mathbf{2} \mathbf{m}$ \\
\hline Hrm1.0 & No & No & No \\
\hline Hrm1.1 & Yes & Possible & Doubtful \\
\hline Hrm1.2 & Yes & Probable & Possible \\
\hline Hrm2 & Yes & Probable & Possible \\
\hline Hrl1.1 & Yes & Possible & Doubtful \\
\hline Hrl1.2 & Yes & Probable & Possible \\
\hline Hb & Possible & Doubtful & Doubtful \\
\hline Hc & Yes & Probable & Possible \\
\hline HIm1 & Yes & Yes & Possible \\
\hline HIm2 & Yes & Yes & Possible \\
\hline Pm, Pd, Pp, Pi & Yes & Doubtful & No \\
\hline Tc, Tw, Tm & Yes & Doubtful & No \\
\hline
\end{tabular}

Artifacts are most likely to be encountered on the natural levees of abandoned channels associated with the Hrm2, Hrm1.2, and Hrm1.1 courses. Artifacts may be located either on these landform surfaces or as part of the sediments that form these landforms. Lack of sites upon the older floodplain surfaces may be due to vertical accretion of sediment. 
Further investigations on the Hrm2 surface in the Finn Bayou segment are probably needed. Geomorphic data indicate that some abandoned channels and courses comprising this surface possibly formed during the early Holocene. Archaeological site data may provide additional evidence to the age of the various floodplain components. Backswamp veneers over older meander belts have possible potential for buried sites.

Summits (Tc, Tw, and Tm) and terraces (Pp and Pi) have high potential for surface sites. Because Tertiary summits and slopes and Pleistocene terraces are stable to erosive landforms, buried sites are not to be expected.

\subsection{Site preservation and destruction}

In the project area, a number of processes is or has been at work either preserving or destroying the evidence of prehistoric groups. Most evidence of these processes is the result of historic man, such as cultivation of the soil, timbering, construction of roads, buildings, and levees, and removal of the Red River Raft. However, natural processes have also played a key role in the preservation or destruction of the archeological record. Some geomorphic processes, such as lacustrine sedimentation or fluvial sedimentation, may serve to preserve the record through burial. Erosional processes may destroy sites by redistribution or destruction of the surfaces where sites occur. In the following paragraphs, the archeological significance of several processes is discussed.

An understanding of fluvial sedimentation rates is important in evaluating artifact decay and preservation characteristics. Knowledge about sedimentation rates is also important in understanding the stratigraphic or chronological significance of the archaeological record. Rapid sedimentation will promote the preservation and superposition of artifacts and features that result from serial occupation of sites (Ferring 1986). In contrast, slow sedimentation rates will result in the accumulation of archaeological debris as mixed assemblages and increase the potential for artifact decay by both chemical and physical causes.

Therefore, it is important to understand, at least in general terms, local sedimentation rates to address the potential for site preservation and the types of sites that will be preserved. Sedimentation rates in the project area were interpreted from geomorphic evidence and are based on field observations and analysis of the available data. Guccione (1995) published sediment rates for the Item 2 and 3 area. She found $1.18 \mathrm{in} .(3 \mathrm{~cm})$ per year 
in a decade scale for proximal natural levee, $0.01 \mathrm{in} .(0.3 \mathrm{~cm})$ per year on a decade to century scale for distal natural levees, and $0.001 \mathrm{in} .(0.003) \mathrm{cm}$ per year on a century to millennium scale for backswamp. Careful application of sediment rates requires thinking about both the temporal and spatial locations of the site. Sedimentation is a function of distance to the active channel and episodic overbank deposition.

\subsection{Geomorphic evidence and archaeological significance of sedimentation rates}

\subsubsection{Geomorphic evidence and sedimentation model}

Geomorphic mapping and published data were the principal means of determining sedimentation rates in the study area. Types of evidence include sedimentary structure, soil profile development, bioturbation, and fossil preservation. The types of evidence and a general knowledge of the different processes operating within each landform make it possible to estimate sedimentation rates for the landforms identified in Table 3.

Sedimentation rates in the study area must be considered in terms of the present day and when the landform was formed. Erosion and sediment transport are occurring throughout the project area. Sedimentation rates on the Red River floodplain area are also considered to be high, estimated at approximately $3 \mathrm{ft}(1 \mathrm{~m})$ per 1,00o years (Smith 1982). In addition, because of the Red River Raft, sedimentation accelerated the aggrading of the Red River in the southern portion of the project area by adding 3 to $4 \mathrm{ft}$ (0.91 to $1.22 \mathrm{~m}$ ) of lacustrine sediment during the past 500 years

(Albertson and Dunbar 1993). In contrast, the lowest sedimentation rates occur on the terraces and backswamp areas removed from semiannual flooding. Valley slopes and summits are mainly locations of weathering and erosional processes.

Site preservation and destruction characteristics of the different landforms, as a function of sedimentation, were evaluated for different types of archaeological artifacts in Table 4. Artifacts are animal bones, shell, charcoal, ceramics, crystalline lithics, and granular lithics. Landforms were evaluated according to their ability to enhance preservation or accelerate decay. The interpretations made in Table 4 were based on the deterioration of archaeological sites primarily by chemical weathering in a humid environment with the main preservation influence by burial from fluvial sedimentation. 
Table 4. Geomorphology of the Red River Levee Rehabilitation Project area.

\begin{tabular}{|c|c|c|c|c|c|c|c|c|c|c|}
\hline \multirow[b]{2}{*}{ Surface } & \multirow[b]{2}{*}{ Landform - formation } & \multirow[b]{2}{*}{ Age $^{a}$} & \multirow{2}{*}{$\begin{array}{l}\text { Geomorphic } \\
\text { process }^{b}\end{array}$} & \multirow[b]{2}{*}{ Rate $^{c}$} & \multicolumn{6}{|c|}{ Archaeological artifacts } \\
\hline & & & & & $A B$ & SH & $\mathrm{CH}$ & CE & $C L$ & GL \\
\hline \multirow[t]{7}{*}{ Floodplain } & Point bar (Hrm1) & $\mathrm{H}$ & LA & $M-R$ & B & $B$ & B & $B$ & $N$ & $\mathrm{~N}$ \\
\hline & Point bar (Hrm2) & $\mathrm{H}$ & LA-VA-BT-SF & M & B & $B$ & B & $B$ & $N$ & B \\
\hline & Raft Lake/Backswamp & $\mathrm{H}$ & VA & $M-R$ & $E$ & $E$ & $A$ & $E$ & $N$ & $\mathrm{~N}$ \\
\hline & Abandoned course & $\mathrm{H}$ & LA-VA & M & $E$ & $E$ & A & $E$ & $N$ & $\mathrm{~N}$ \\
\hline & Abandoned channel & $\mathrm{H}$ & LA-VA & M & $E$ & $E$ & $A$ & $E$ & $N$ & $N$ \\
\hline & Natural levee (Hrl1) & $\mathrm{H}$ & VA & $M-R$ & $A$ & $A$ & $A$ & $A$ & $N$ & $N$ \\
\hline & Natural levee (Hrl2) & $\mathrm{H}$ & VA-BT-SF & M-R & A & $A$ & A & A & $N$ & $N$ \\
\hline Terrace & $\begin{array}{l}\text { Abandoned floodplain } \\
\text { (Pi) }\end{array}$ & $P$ & E-SF & $\mathrm{L}$ & A & $A$ & A & A & $N$ & $N$ \\
\hline $\begin{array}{l}\text { Bluffs and } \\
\text { slopes }\end{array}$ & $\begin{array}{l}\text { Tertiary geology, (Tw) } \\
\text { Wilcox group }\end{array}$ & $T$ & E-SF & $\mathrm{L}$ & A & $A$ & A & A & $N$ & $N$ \\
\hline
\end{tabular}

a Age: $\mathrm{H}=$ Holocene, $\mathrm{P}=$ Pleistocene, $\mathrm{T}=$ Tertiary.

b Geomorphic process: VA = Vertical accretion, LA = Lateral accretion, SF = Soil forming processes (Pedogenesis), BT = Bioturbation (organic mixing by vegetation and organisms), $\mathrm{E}=$ Erosion.

c Rate of deposition: $L=$ Low, $M=$ Medium, $R$ = Rapid.

d Archaeological artifact: $\mathrm{AB}=$ animal bones, $\mathrm{SH}=$ shell, $\mathrm{CH}=$ charcoal, $\mathrm{CE}=$ ceramics, $\mathrm{CL}=$ crystalline lithics, $\mathrm{GL}=$ granular lithics, $\mathrm{A}$ = accelerates decay, $\mathrm{E}=$ enhances preservation, $\mathrm{B}=$ both; may accelerate decay or enhance preservation, $\mathrm{N}=$ neutral or no effect.

\subsubsection{Discussion}

Preservation and destruction qualities of landforms are site dependent and are based on a number of interdependent variables. These variables include soil $\mathrm{pH}$, soil moisture, wet aerobic or anaerobic environments, types of microorganisms and macroorganisms present, sediment movement, and soil loading. The relationships between these variables are complex. They can vary slightly and result in different decay properties for different artifact types. Hamilton (1987), Steele (1987), Vaughn (1987) and Mathewson and Gonzales (1988) described the effects that each of these variables has on artifact deterioration in archaeological sites. The majority of artifacts identified in the archaeological site descriptions are lithics.

Chemical weathering promotes the decay of bone, shell, charcoal, and pottery. Stone artifacts are not affected. With increasing sedimentation and burial, artifact preservation is greatly enhanced as burial reduces the rate at which chemical weathering occurs. Archaeological sites are most 
threatened on the summits and on the side slopes where sedimentation rates are very low or where erosion is the dominant process.

Archaeological sites are more likely to be protected adjacent to or near the main channel where maximum sedimentation and burial occurs. Sites that are in close proximity to the main channel and not in the direct path of lateral migration by the river are buried by vertical accretion. Other factors to be considered in a discussion of artifact preservation and decay for geomorphic systems include flooding effects, groundwater movements, and fluvial scouring. Flooding can accelerate artifact decay by altering both the chemical and physical processes normally operating. Artifacts may be affected by groundwater movements and associated chemical reactions. Terraces are especially affected by groundwater movements as they are composed primarily of unconsolidated sediments and are hydraulically connected to the main channel. Other indirect and potentially adverse effects of flooding on archaeological sites include riverbank caving following a rapid river drawdown.

There are no strict rules governing archaeological site preservation or destruction as a function of the respective landforms and associated geomorphic processes. Various trends or generalizations that have previously been identified can be used as guidelines in evaluating the archaeological significance of the different landforms. Specific areas or individual archaeological sites should be examined and evaluated on the merits of each site. 


\section{Summary and Conclusions}

\subsection{Geomorphology}

Geomorphic mapping has identified three primary landform surfaces (i.e., bluffs, terraces, and the floodplain) that are further subdivided according to environments of deposition or underlying geology. Bordering the floodplain of the different fluvial systems in the study area are topographically higher Pleistocene terrace and valley slopes composed of Tertiary age sediments. Three Pleistocene age terraces were identified and mapped adjacent to the main Red River Valley. The major floodplain environments of deposition, point bar, abandoned channel, abandoned course, backswamp, and natural levees were identified or mapped as separate environments of deposition.

The development of the study area began during the late Tertiary and early Pleistocene. Fluvial downcutting and lateral migration by the various stream courses created a well-defined alluvial valley and floodplain. Terraces are situated along the valley walls midway between the Tertiary uplands and the floodplain. Geomorphic data and published works (Russ 1975; Pearson 1982; and Saucier and Snead 1989) indicate two to three meander belts in the study area. The older meander belt Hrm2 surface may extend in age from approximately 4,000 years BP to possibly the middle Holocene. The intermediate meanders (Pearson 1982), designated Hrm1.2 in this report, are possibly 4,000 to 1,200 years BP. Meander belt Hrm1.1 is estimated to represent 1,200 to 200 years BP. The modern meander belt (Hrm1.0) is approximately 200 years BP to present.

Formation of the Red River Raft during late prehistoric and early historic times blocked channel flow on the Red River and created a series of large lakes. Poston and Swan lakes were formed as a result of the raft. Historic and geomorphic data indicate that the lakes were formed less than 500 years ago.

\subsection{Archaeological significance}

Historic archaeological sites were not evaluated by this study. The majority of prehistoric archaeological sites is located on terraces and valley slopes and former abandoned channels adjacent to Finn Bayou. 
It is probable that sites may be buried beneath vertical accretion. Vertical accretion processes throughout the Holocene could have buried sites to $10 \mathrm{ft}(3.05 \mathrm{~m})$ based on similar sites reported for the Red River Valley (Smith 1982).

Caddo sites generally correlate with natural levee deposits associated with the meander belts. These sites are located on natural levees of abandoned channels and courses connected to the Hrm1.1 and Hrm2 meander belts.

Archaic sites are concentrated mainly along crevasse channels and the Finn Bayou course. Additional Archaic sites within the floodplain may be buried by vertical accretion of sediment, and/or the landforms that comprise the floodplain may be younger at some locations. The potential for archaeological sites at the surface and in the subsurface in the Finn Bayou area is considered to be very favorable. Both surfaces and buried sites are highly probable for Hrm2 and Hrm1.2 surfaces. Other locations occur in close proximity to crevasse channels.

Existing data suggest that the different floodplain components may extend into the late Holocene. Exact chronological boundaries are not possible with the limited data presently available. The archaeological record may provide additional evidence to determine more specific chronological boundaries and ages for the various floodplain features. 


\section{References}

Abington, O. D. 1973. Changing meander morphology and hydraulics, Red River Arkansas and Louisiana. PhD diss., Louisiana State University. Ann Arbor, MI: University Microfilms.

Albertson, P. E. 1992. Geologic reconnaissance of the Shreveport, Louisiana, to Daingerfield, Texas Reach, Red River Waterway. Technical Report GL-92-1. Vicksburg, MS: U.S. Army Engineer Waterways Experiment Station.

Albertson, P. E., and J. B. Dunbar. 1993. Geomorphic investigation of the Shreveport, Louisiana, to Daingerfield, Texas Reach, Red River Waterway. Technical Report GL-93-31. Vicksburg, MS: U.S. Army Engineer Waterways Experiment Station.

Bates, R. L., and J. A. Jackson. 1980. Glossary of geology. Falls Church, VA: American Geologic Institute.

Birkeland, P. W. 1984. Soils and geomorphology. New York: Oxford University Press.

Caldwell, N. W. 1941. The Red River Raft. Chronicles of Oklahoma 19:253-68.

Chorley, R. J., S. A. Schumm, and D. E. Sugden. 1984. Geormorphology. New York: Methuen \& Co.

Daniels, R. B., and R. D. Hammer. 1992. Soil geomorphology. Somerset, NJ: John Wiley \& Sons, Inc., NY.

Darby, W. 1816. A geographical description of the state of Louisiana. Philadelphia, PA: John Melish.

Dunbar, William. 1804. Documents relating to the purchase and exploration of Louisiana. New York: Houghton Mifflin.

ESRI. 1994. GIS. Arc/Info Version 7 Commands Reference Volumes, Environmental Systems Research Institute, Inc.

Ferring, C. R. 1986. Rates of fluvial sedimentation: Implications for archaeological variability. Geoarcheology 1(3):259-74. New York: Wiley.

Fisk, H. N. 1938. Geology of Grant and LaSalle Parishes. Louisiana Geological Survey Bulletin No. 10. Baton Rouge, LA.

Fisk, H. N. 1940. Geology of Avoyelles and Rapides Parishes. Louisiana Geological Survey Bulletin No. 18. Baton Rouge, LA.

Flint, T. 1833. The history and geography of the Mississippi Valley. Cincinnati, OH: E. H. Flint.

Flores, D. L. 1984. The ecology of the Red River in 1806: Peter Custis and early southwestern natural history. Southwestern Historical Quarterly 88. 
Gould, R. A. 1987. Part II: Archaeological frameworks for evaluation site-formation processes. In Interdisciplinary workshop on the physical-chemical-biological processes affecting archaeological sites, ed. C. C. Mathewson, Texas A \& M University. Vicksburg, MS: U.S. Army Engineer Waterways Experiment Station.

Guardia, J. E. 1933. Some results of the log jam(s) in the Red River. Geographical Society of Philadelphia 31(3):103-14.

Guccione, M. J. 1995. Geomorphology of the Red River near Fulton, Arkansas in archeological investigations in the Great Bend Region, Miller County, Arkansas, Levee Item 2 and 3. Mid-Continental Research Associates.

Hall, S. A. 1990. Channel trenching and climatic change in the southern U.S. Great Plains. Geology 18:342-45.

Hamilton, D. L. 1987. Part IV: Archaeological conservation and processes of artifact deterioration. In Interdisciplinary workshop on the physical-chemical-biological processes affecting archaeological sites, ed. C. C. Mathewson, workshop at Texas A \& M University. Vicksburg, MS: U.S. Army Engineer Waterways Experiment Station.

Harms, J. C., D. B. MacKenzie, and D. G. McCubbin. 1963. Stratification in modern sands of the Red River, Louisiana. Journal of Geology 71:566-580.

Harvey, M. D., C. C. Watson, S. A. Schumm, H. S. Pranger, and J. S. Schug. 1987. Geomorphic and hydraulic analysis of the Red River from Shreveport, Louisiana, to Denison Dam, Texas. Project No. 76-106-87, prepared for U.S. Army Engineer District, Vicksburg. Fort Collins, CO: Water Engineering and Technology, Inc.

Heinrich, P. V. 1993. Natural settings. In Cultural resources survey at Red River below Denison Dam, Levee Rehabilitation/Restoration Item 1, Miller County, Arkansas. New Orleans, LA: Goodwin \& Associates.

Jacobs, J. A. 1981. Depositional and quaternary history of the Red River in northeast, Texas. M.S. thesis, Department of Geology. University of Texas, Austin, TX.

Jacobs, J. A. 1985. Fluvial responses to hydrologic changes on the Red River in northeast Texas. Transactions of the Gulf Coast Association of Geological Societies 35: 409-414.

Jenny, H. 1961. Derivation of state factor equations of soils and ecosystems. Soil Science Society American Proceedings 25: 385-388.

Mathewson, C. C., and T. Gonzalez. 1988. Burial of archaeological sites for protection and preservation. In Proceedings for 24th Annual Symposium on Engineering Geology and Soils Engineering, 443-452. Coeur d'Alene, ID: University of Idaho Press.

Mills, G. B. 1978. Of men and rivers. Vicksburg, MS: U.S. Army Engineer District, Vicksburg. 
Pearson, C. E. 1982. Geomorphology and prehistory settlement patterns in the Great Bend Region. In Contributions of the Archeology of the Great Bend Region, ed. F. F. Schambach, 12-29. Arkansas Archeological Survey Research Series 22. Fayetteville, AR.

Pearson, C. E. 1986. Dating the course of the lower Red River in Louisiana: The archaeological evidence. Geoarchaeology 1(39):39-42.

Russ, D. P. 1975. The quaternary geomorphology of the lower Red River Valley, Louisiana. PhD diss. University Park, PA: Pennsylvania State University.

Santeford, L. G. 1994. European and American settlement in Miller County. In A cultural resources assessment of proposed Interstate 71 corridors between Texarkana and Louisiana, Miller County, Arkansas SPEARS Project Report 71. West Fork, AR.

Saucier, R. T. 1974. Quaternary geology of the lower Mississippi Valley. In Arkansas Archeological Survey Research Series, No. 6. Little Rock, AR.

Saucier, R. T., and J. I. Snead. 1989. Quaternary geology map of the lower Mississippi Valley, scale: 1:1,000,000. In Geological Society of America, Decade of North American Geology Series. Boulder, CO.

Saucier, R. T. 1994. Geomorphology and Quaternary Geologic History of the Lower Mississippi Valley, Volume 1, USACE, Vicksburg, MS.

Schambach, F. F. 1982. The archeology of the Great Bend Region in Arkansas. In Contributions to the Archeology of the Great Bend Region, ed. F. F. Schambach, 1-11. Arkansas Archeological Survey Research Series 22. Fayetteville, AR.

Schultz, J. R., and E. L. Krinitzsky. 1950. Geology of the Lower Red River. Technical Memorandum 3-319. Vicksburg, MS: U.S. Army Engineer Waterways Experiment Station.

Schumm, S. A. 1977. The fluvial system. New York: Wiley.

Simonson, R. W. 1959. Outline of a generalized theory of soil genesis. Soil Science Society American Proceedings 23: 152-156.

Smith, F. L., and D. P. Russ. 1974. Geological investigation of the lower Red RiverAtchafalaya Basin area. Technical Report S-74-5. Vicksburg, MS: U.S. Army Engineer Waterways Experiment Station.

Smith, L. M. 1982. Geomorphic investigation of the Bayou Bodcau and Tributaries Project Area, Louisiana. Miscellaneous Paper GL-82-12. Vicksburg, MS: U.S. Army Engineer Waterways Experiment Station.

Soil Conservation Service (SCS). 1979. Soil survey of Hempstead County, Arkansas. Washington, DC: U.S. Department of Agriculture. 1984. Soil survey of Lafayette, Miller and Little River Counties, Arkansas. Washington, DC: U.S. Department of Agriculture. 
Steele, B. G. 1987. Part V: Zooarchaeology, taphonomy, and preservation of the fossil faunal assemblage. In Interdisciplinary workshop on the physical-chemicalbiological processes affecting archaeological sites, ed. C. C. Mathewson. Workshop at Texas A \& M University. Vicksburg, MS: U.S. Army Engineer Waterways Experiment Station.

Stoddard, Major Amos. 1812. Sketches, historical and descriptions of Louisiana. Philadelphia, PA: Mathew Carey.

U.S. Army Corps of Engineers (USACE). 1873. History of the raft obstruction of Red River. Annual report to the Chief of Engineers, U.S. Army Corps of Engineers, Lower Mississippi Valley Division, Vicksburg, MS.

Vaughn, V. B. 1987. Part VI: Botanical remains in archaeological sites. In Interdisciplinary workshop on the physical-chemical-biological processes affecting archaeological sites, ed. C. C. Mathewson. Workshop at Texas A \& M University. Vicksburg, MS: U.S. Army Engineer Waterways Experiment Station.

U.S. Department of Agriculture (USDA). 1993. Soil survey manual. Handbook No. 18, Revised. Washington, DC: USDA.

Veatch, A. C. 1906. Geology and underground water resources of northern Louisiana and southern Arkansas. Professional Paper 44. U.S. Geological Survey. 


\section{Appendix A: Geomorphic Maps}





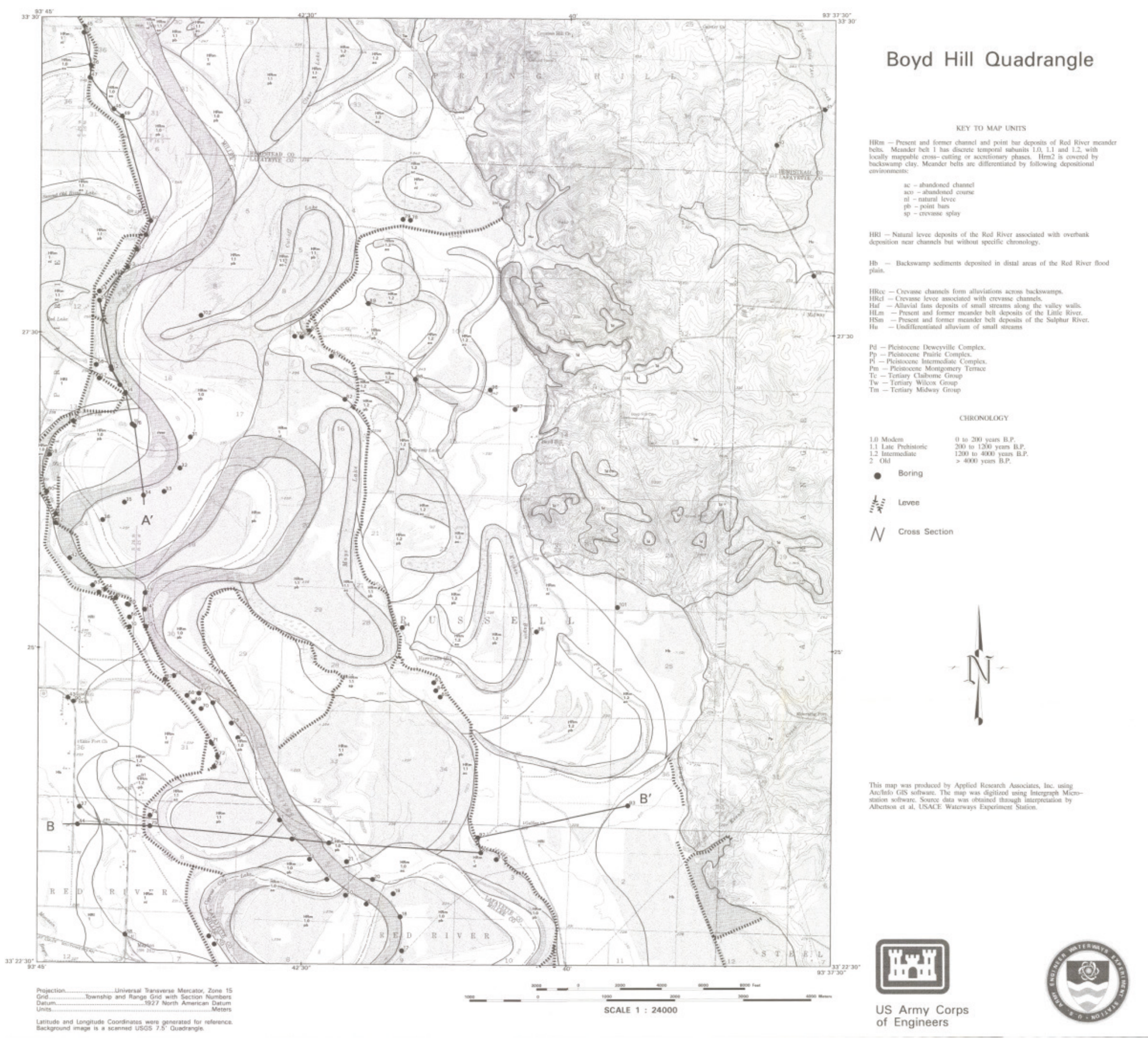




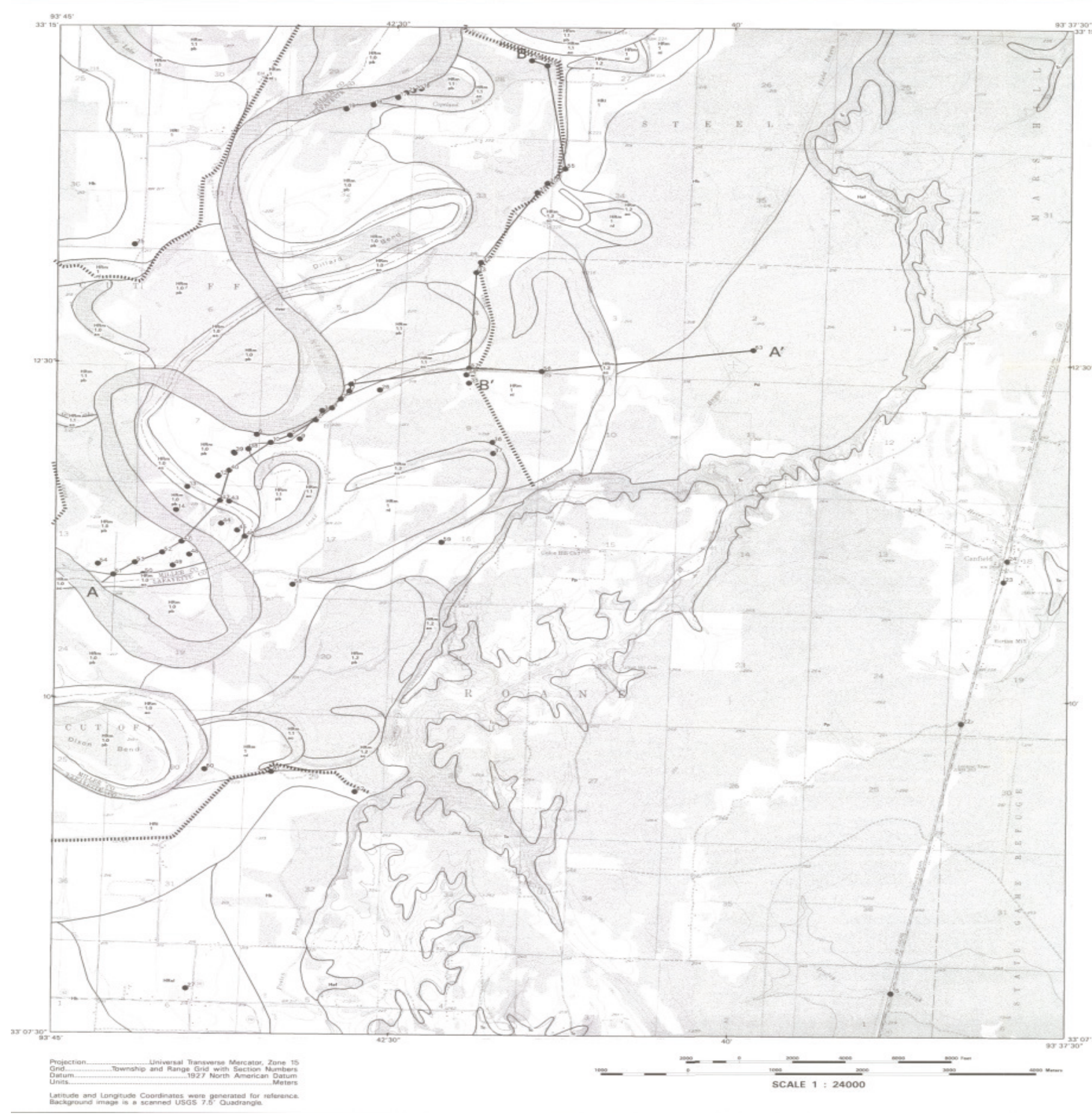

Canfield Quadrangle

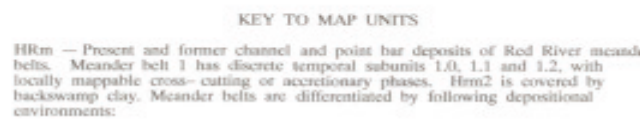

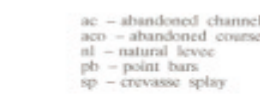

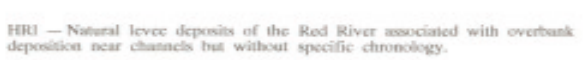

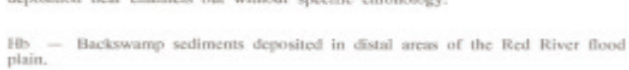

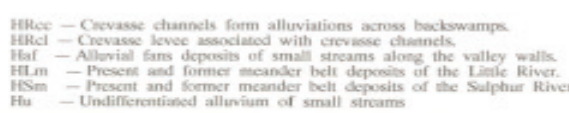

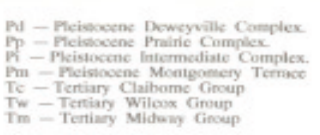

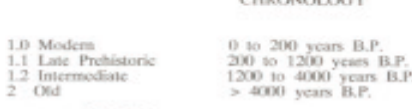

- Boring

Fit Levee

$N$ cross Section

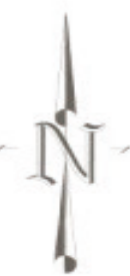

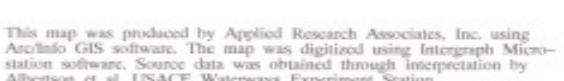




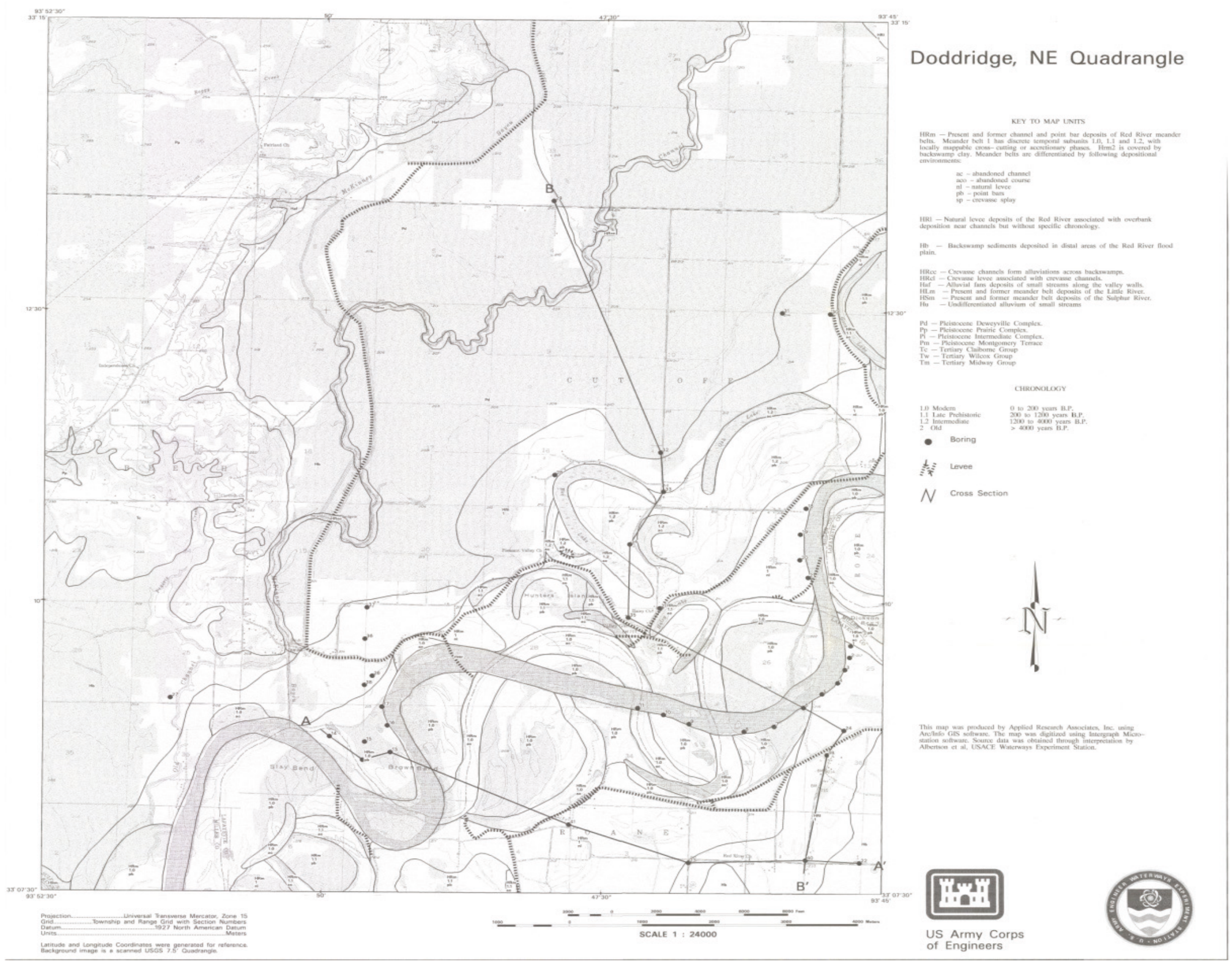




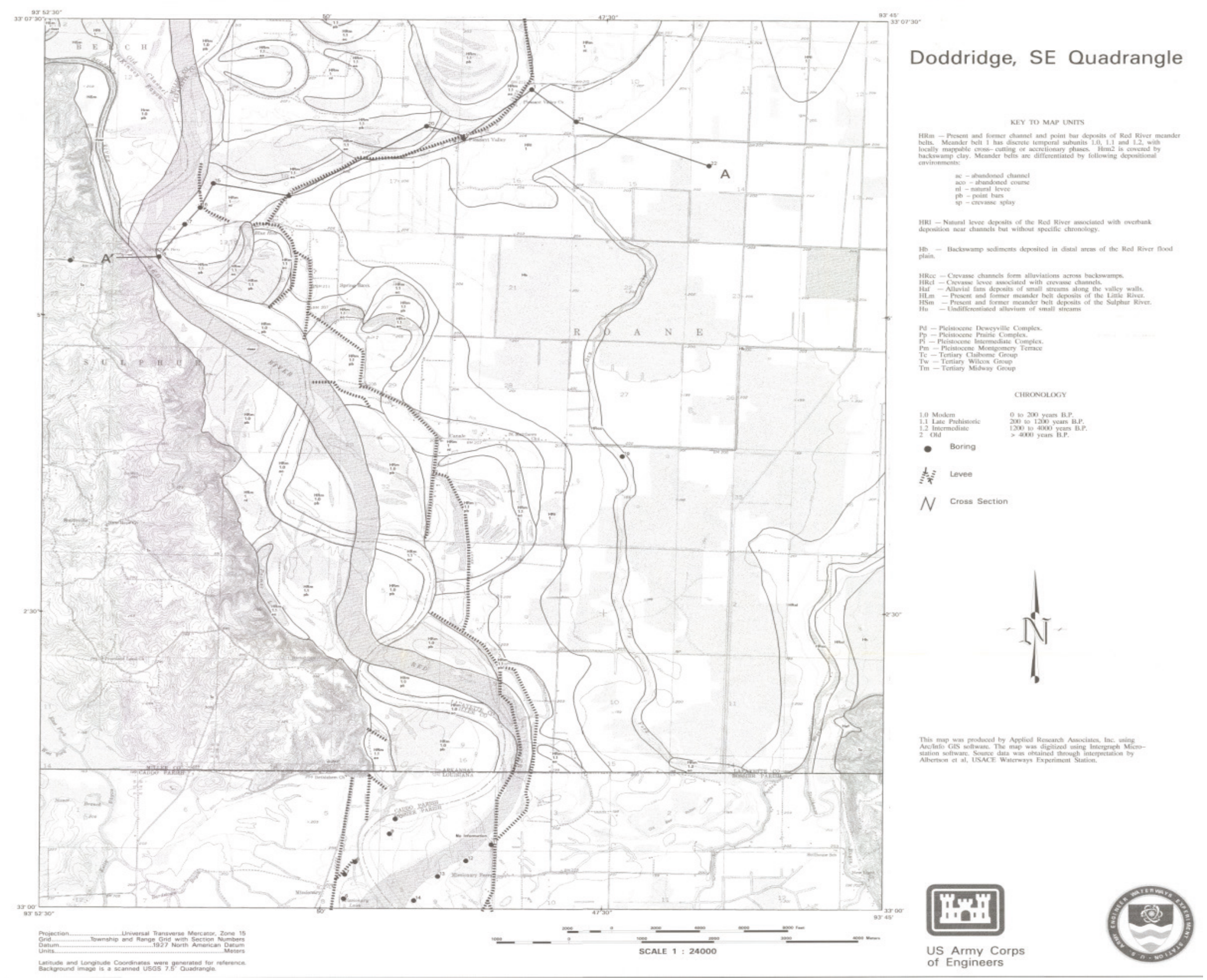




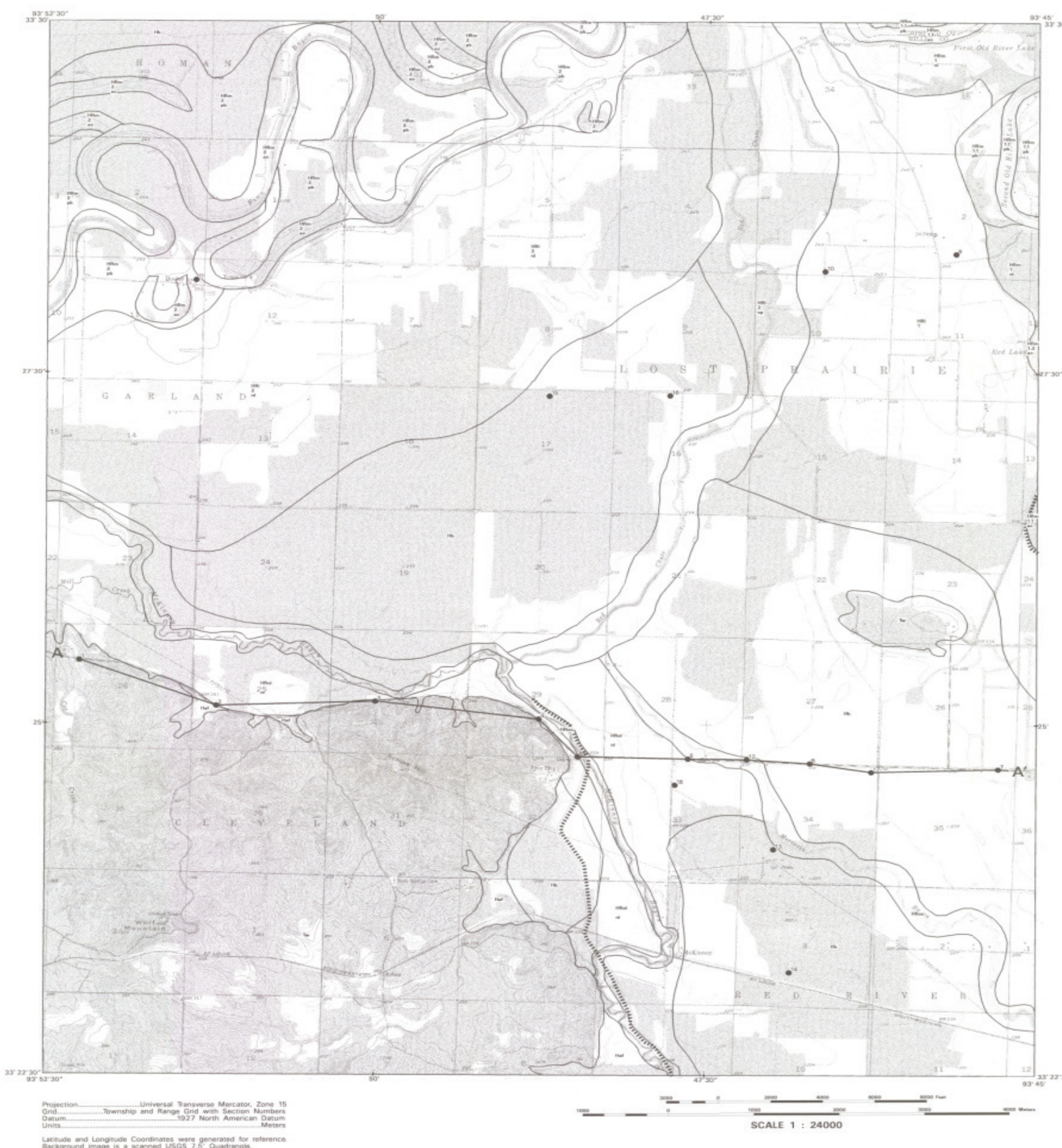

Fouke, NE Quadrangle

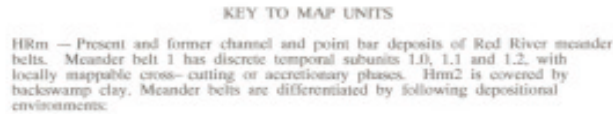

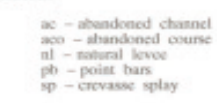

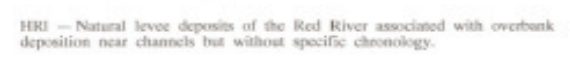

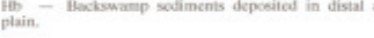

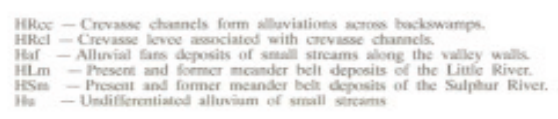

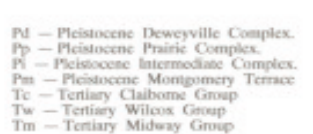

(2)

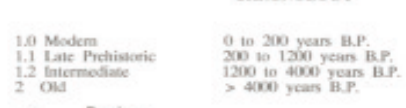

- Boring

$N$ cross Section

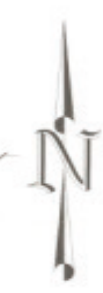

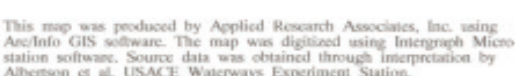

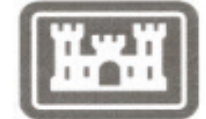

US Army Corps
of Engineers 


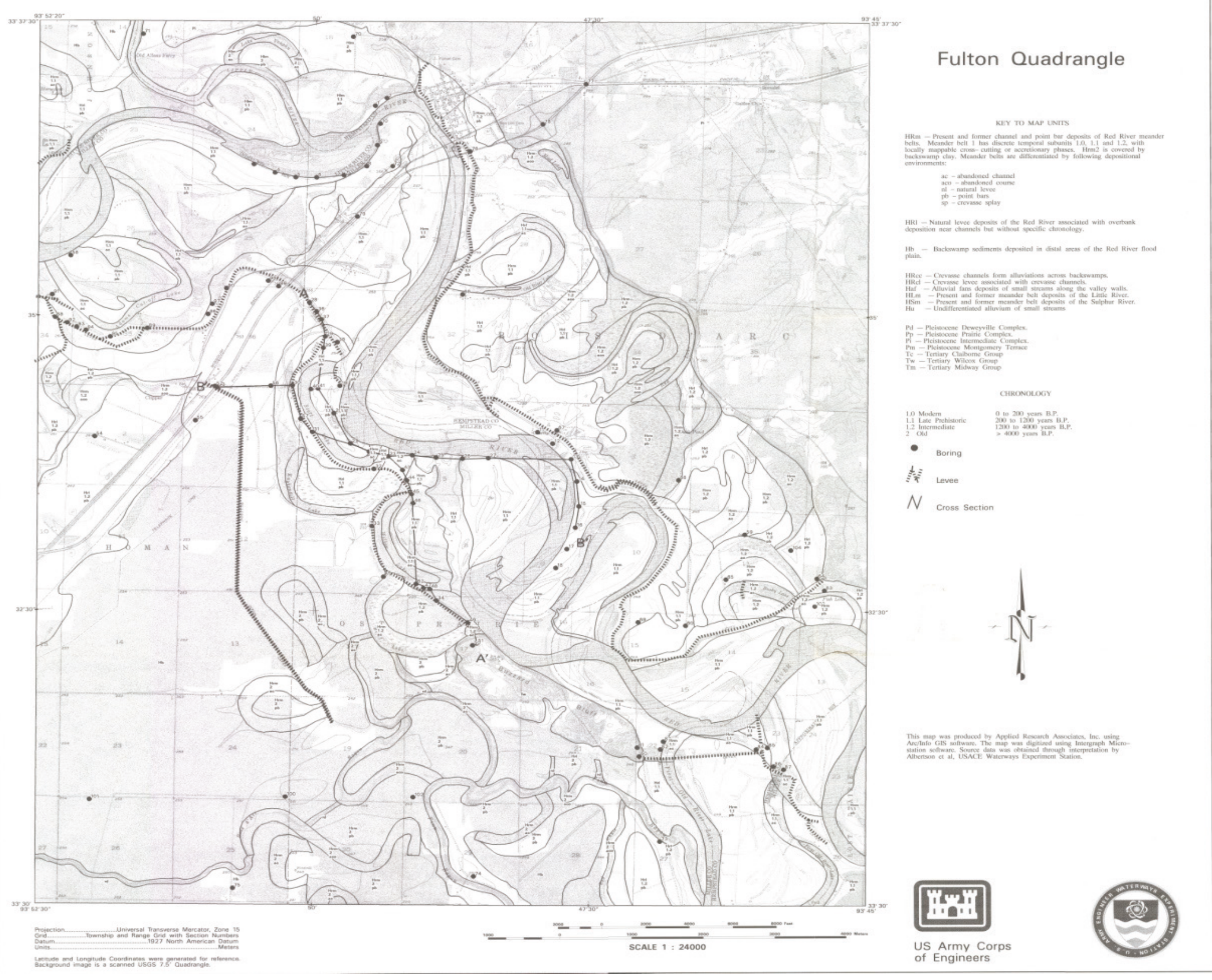




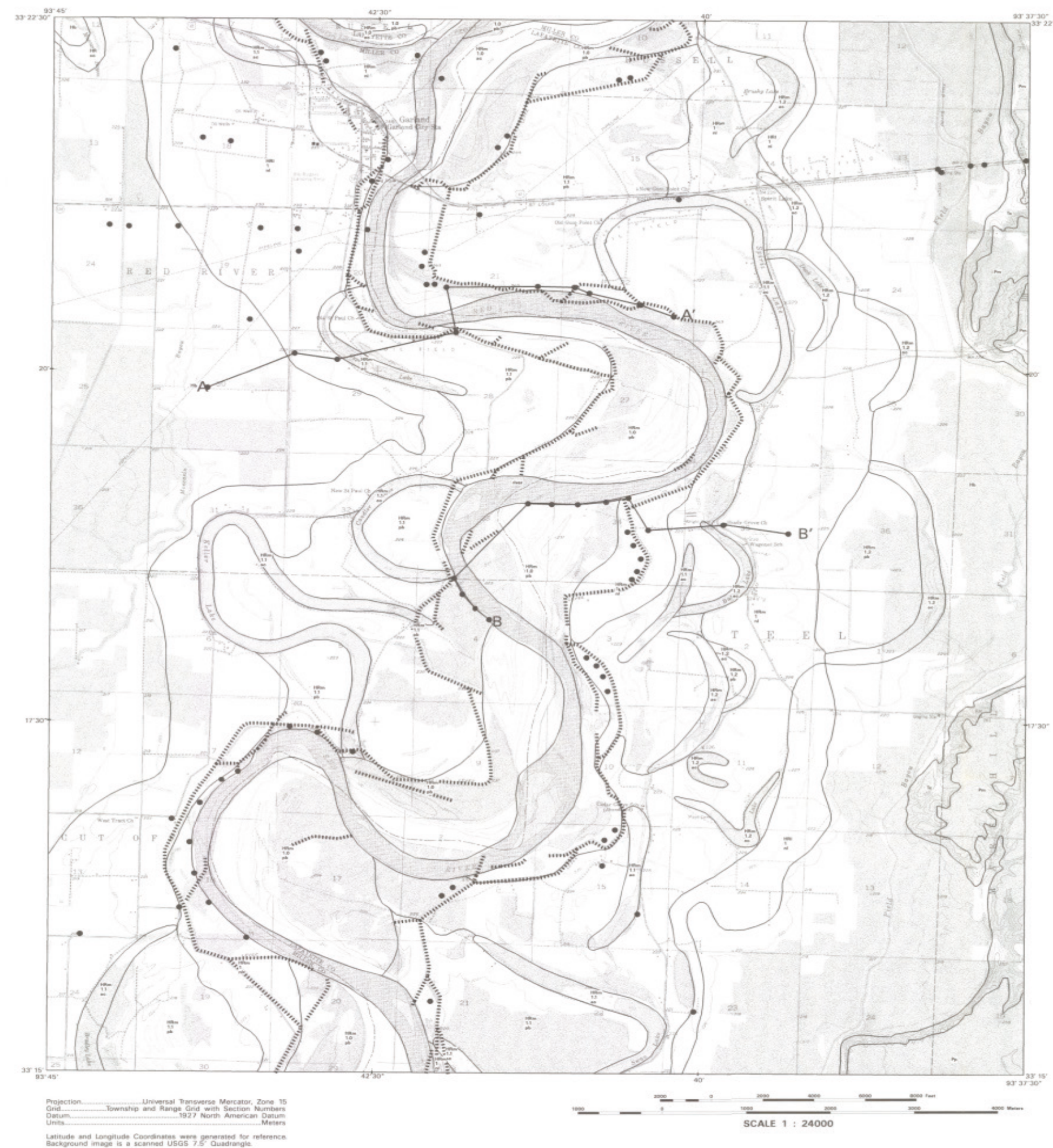

Garland Quadrangle

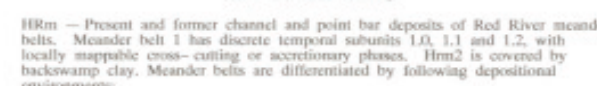

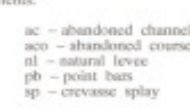

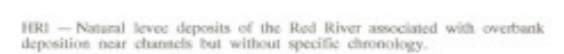

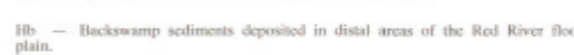

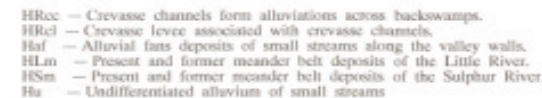

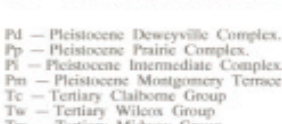

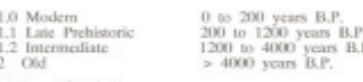

- Boring

LE Levee

$N$ Cross Section

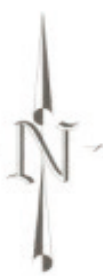

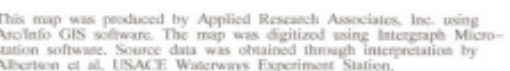




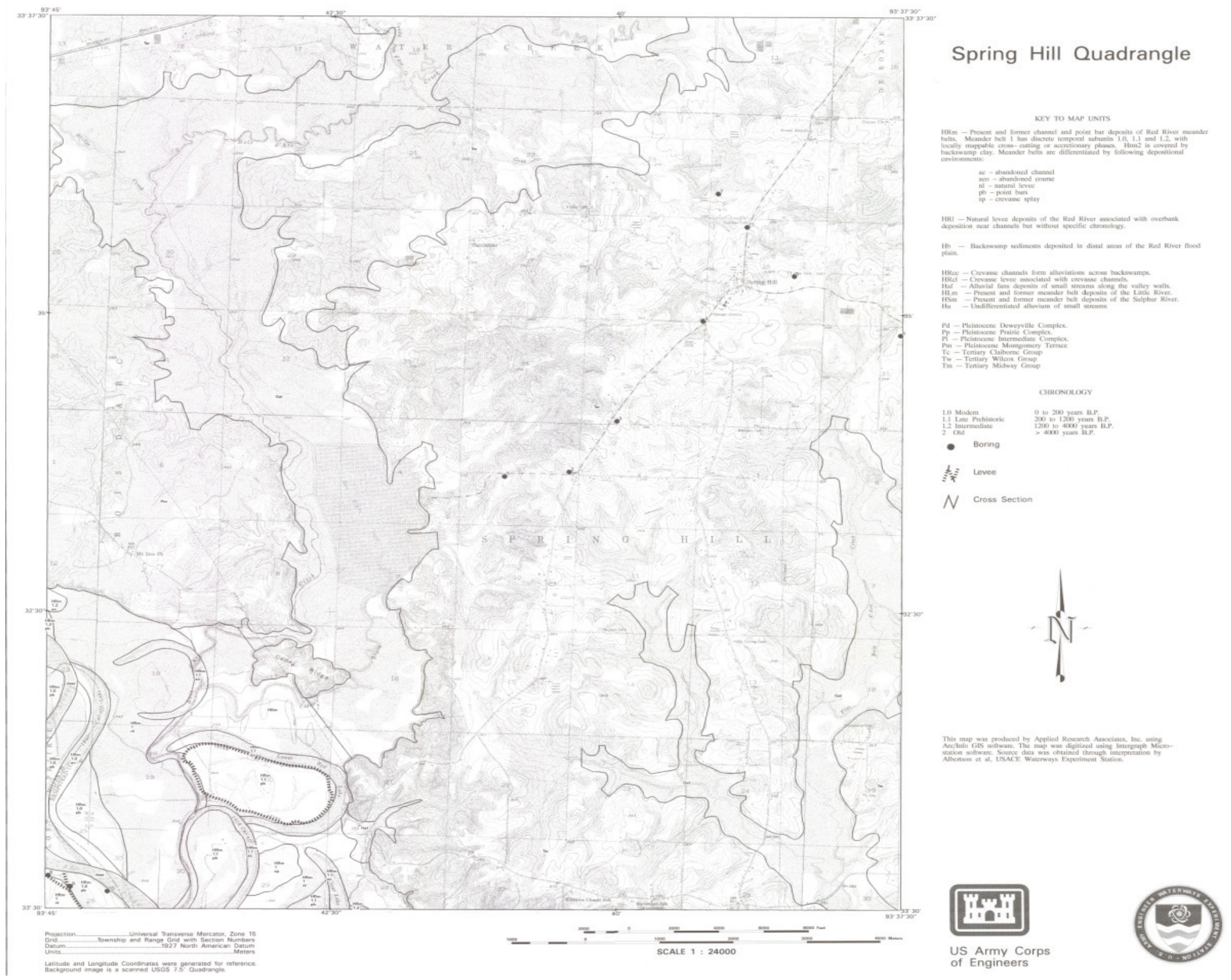




\section{Appendix B: Geomorphic and Geologic Cross Sections}




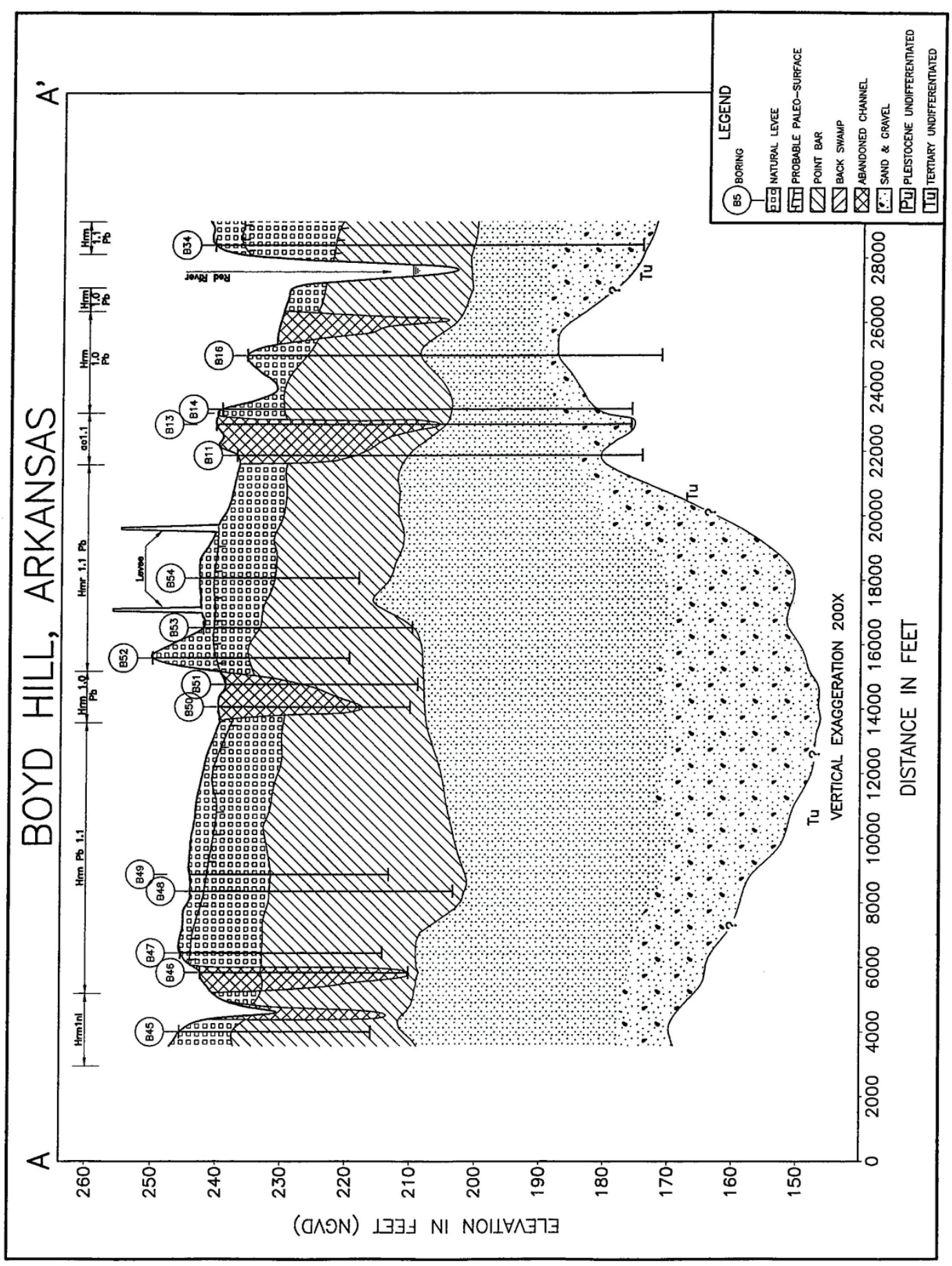




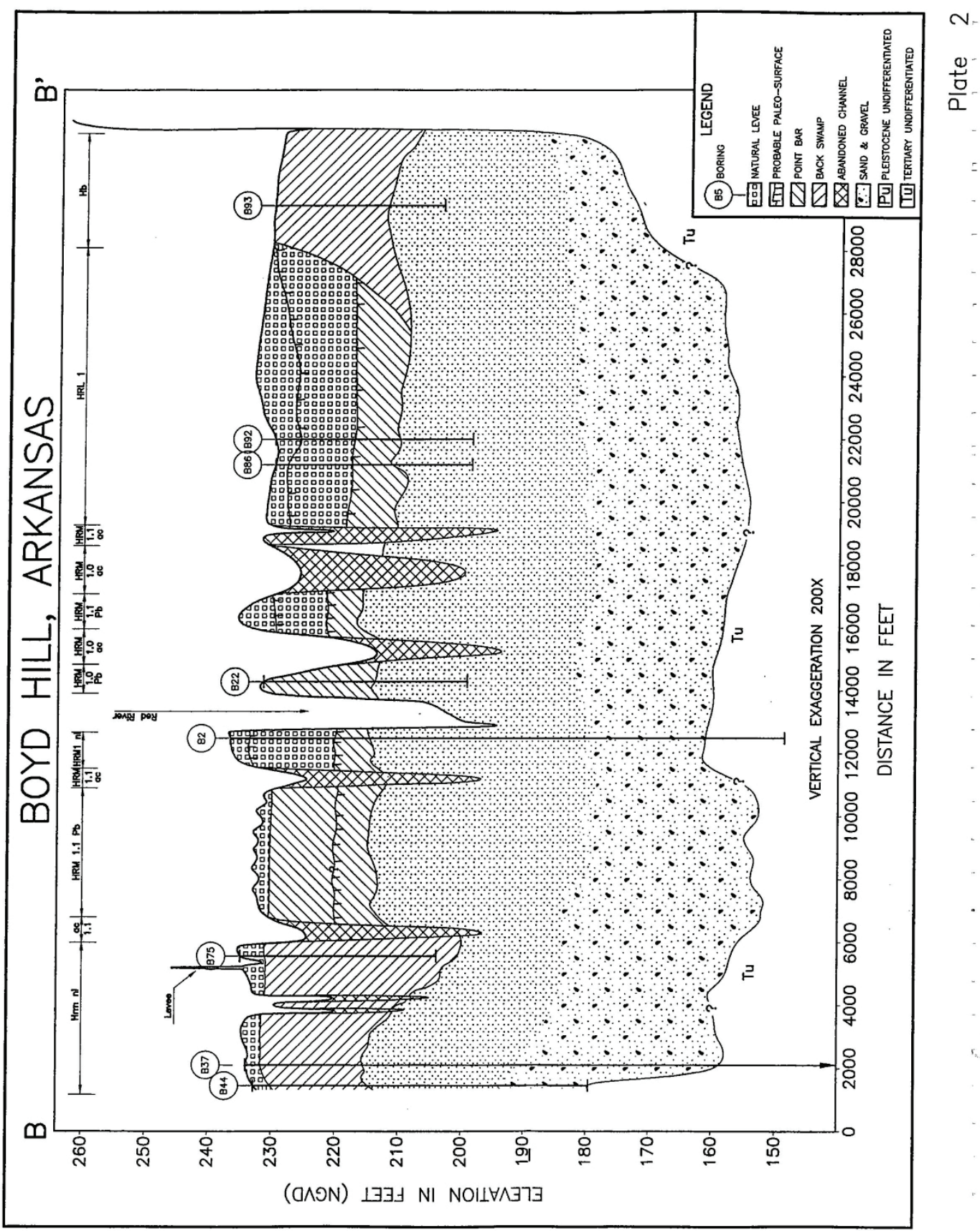




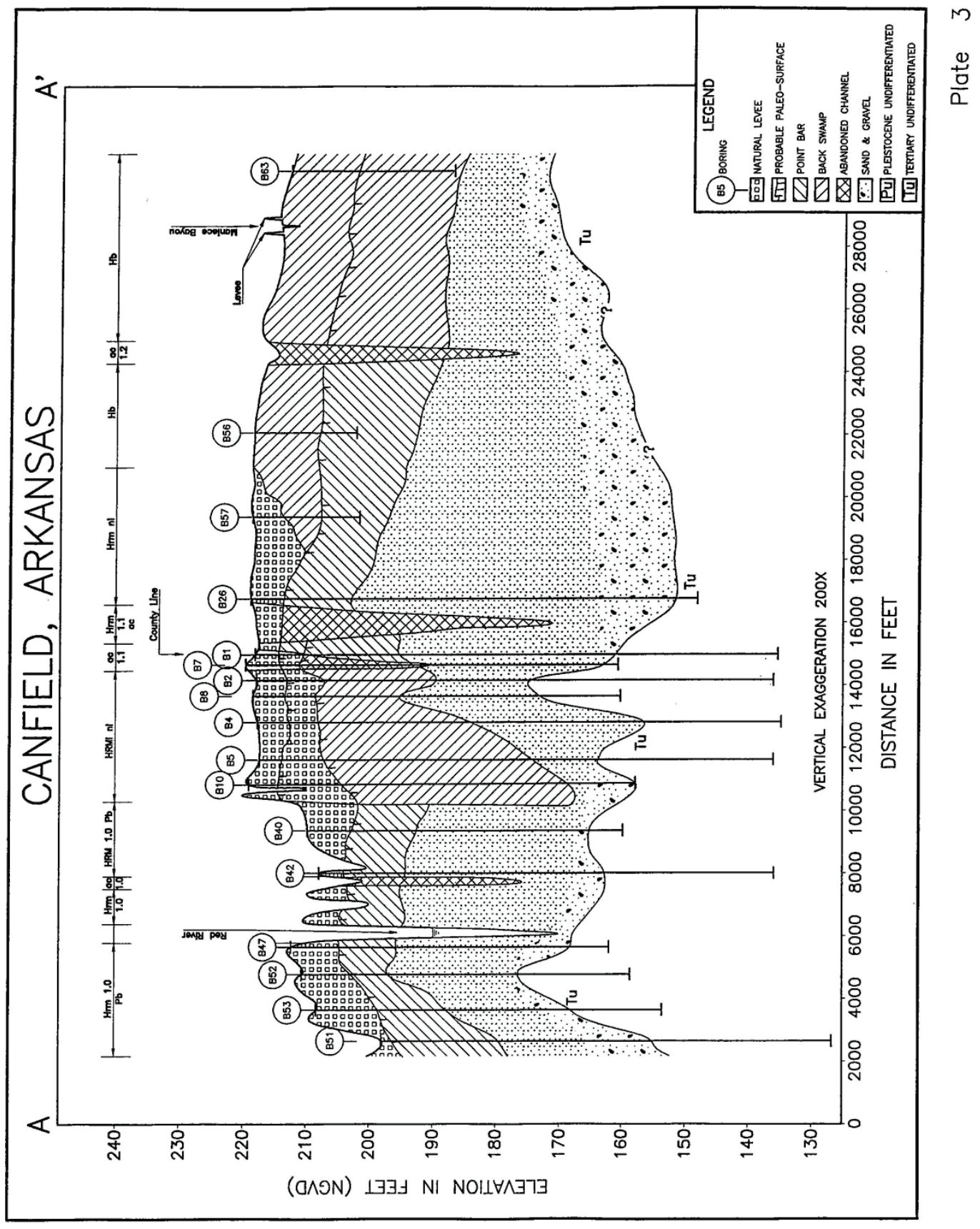




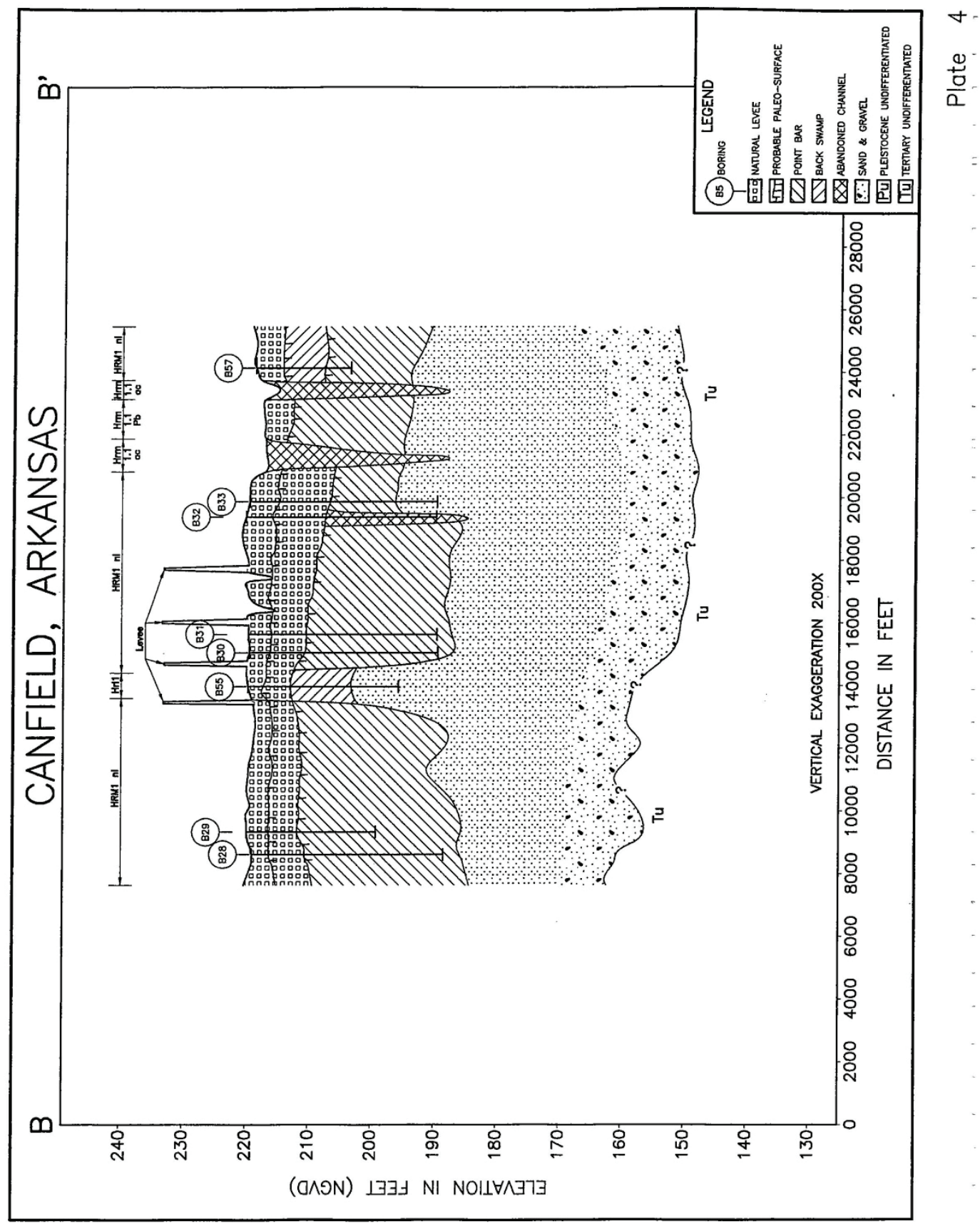




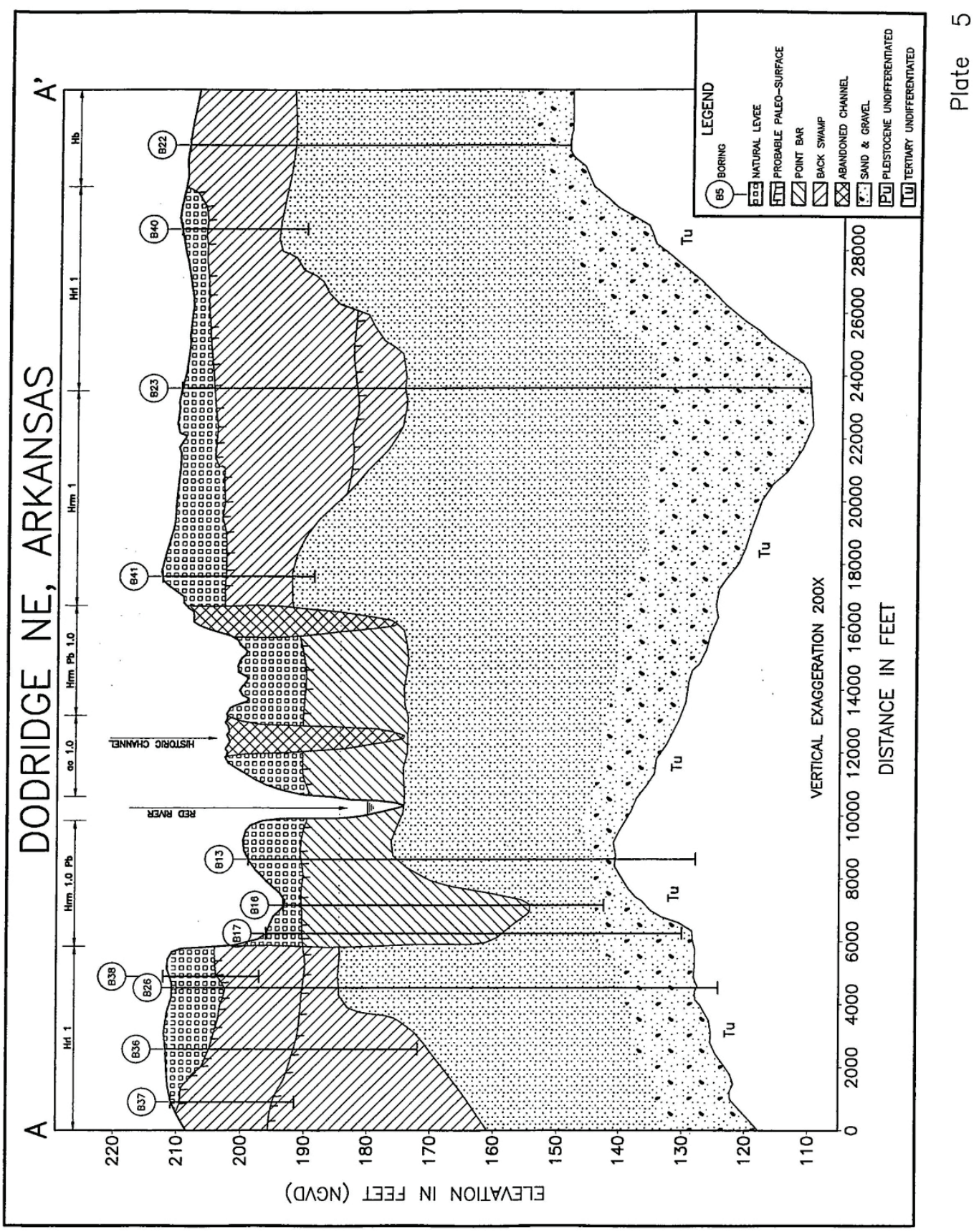




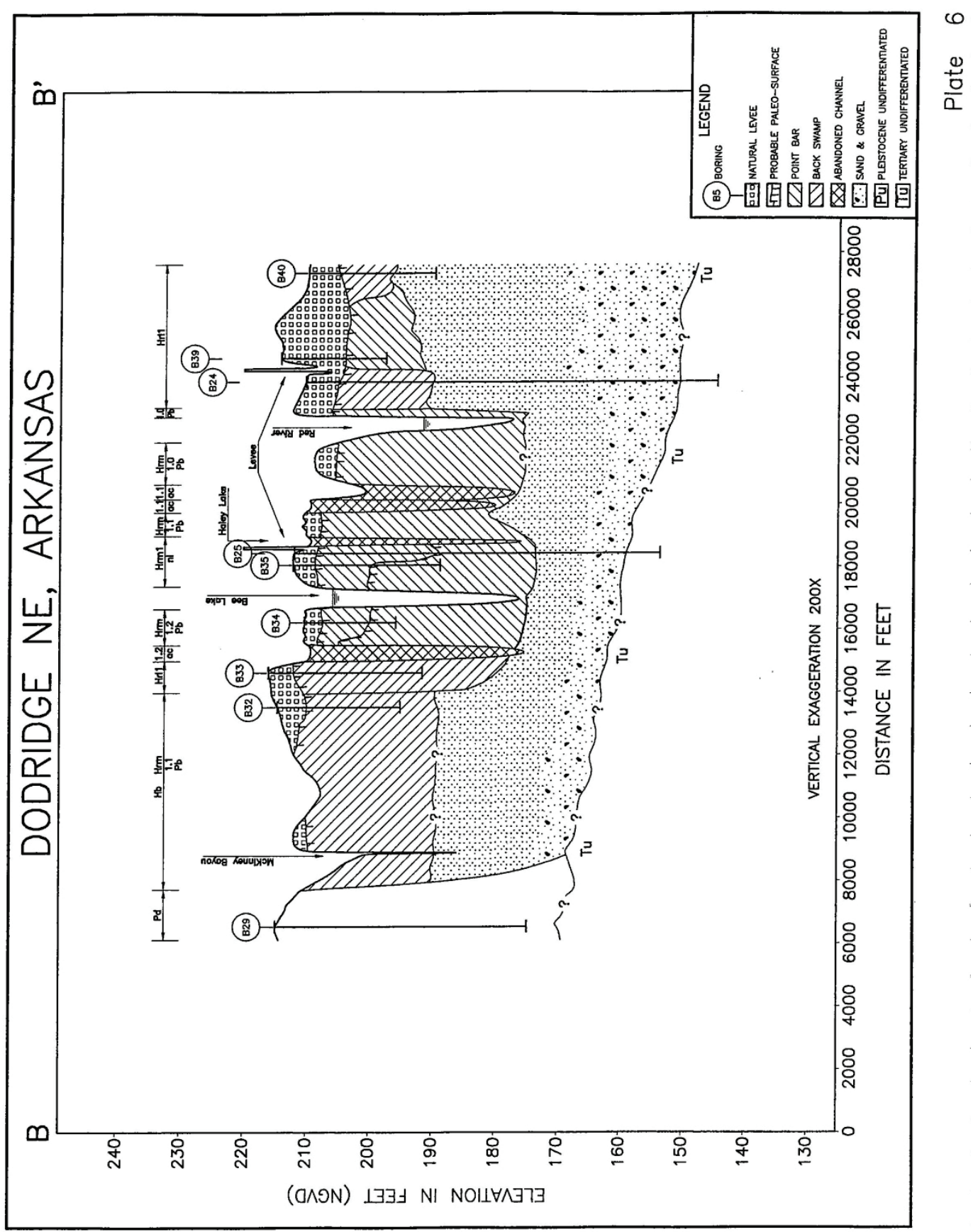




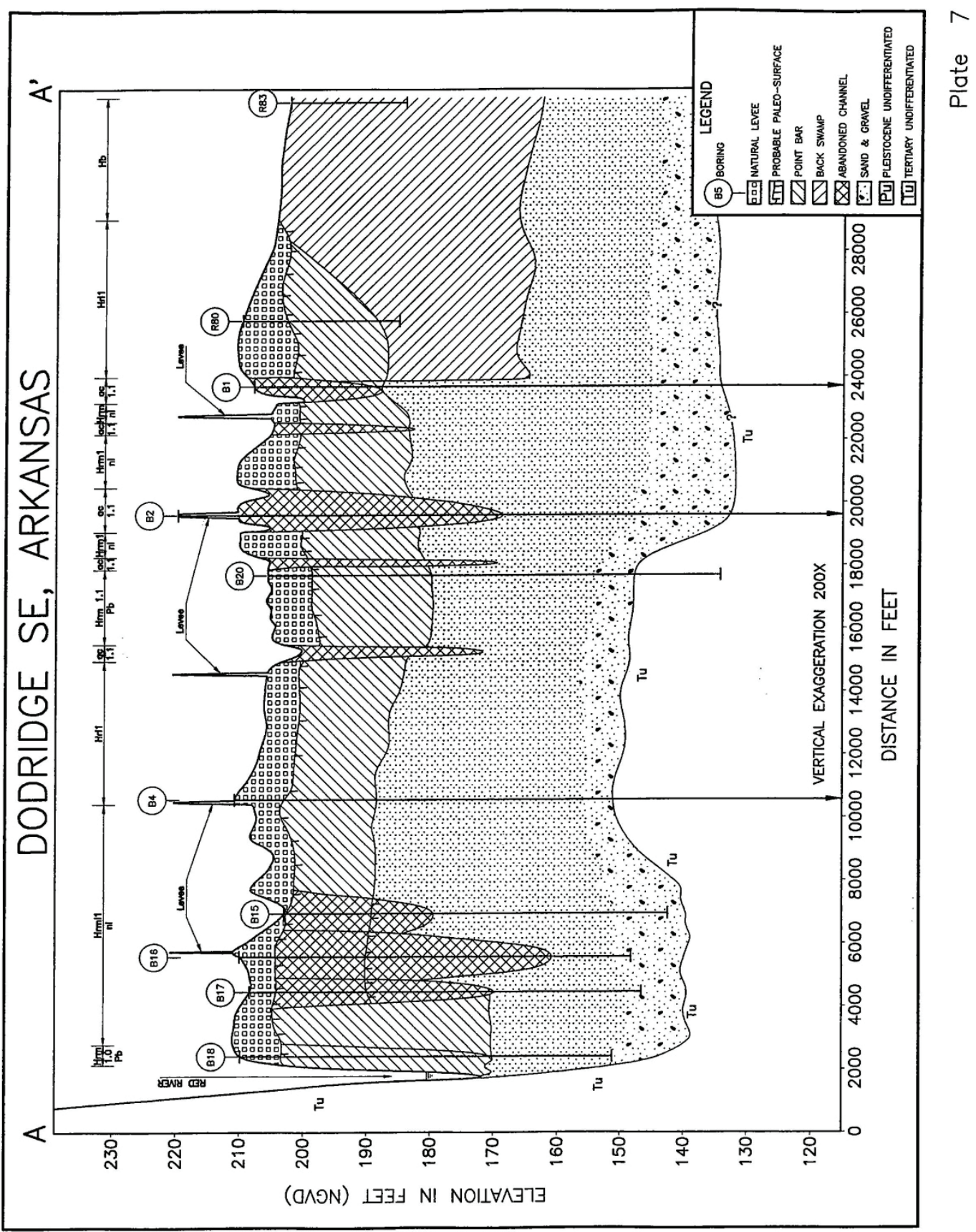




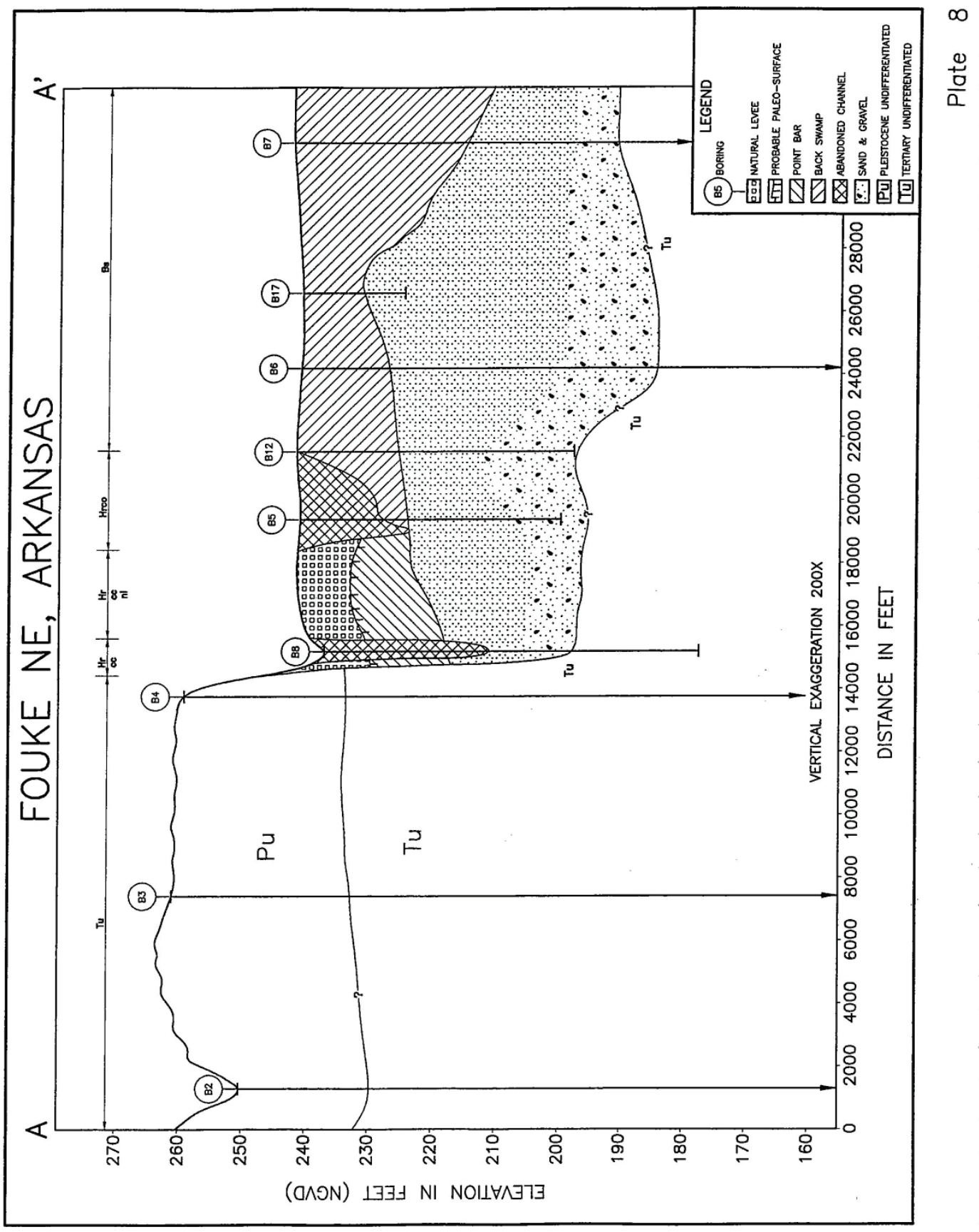




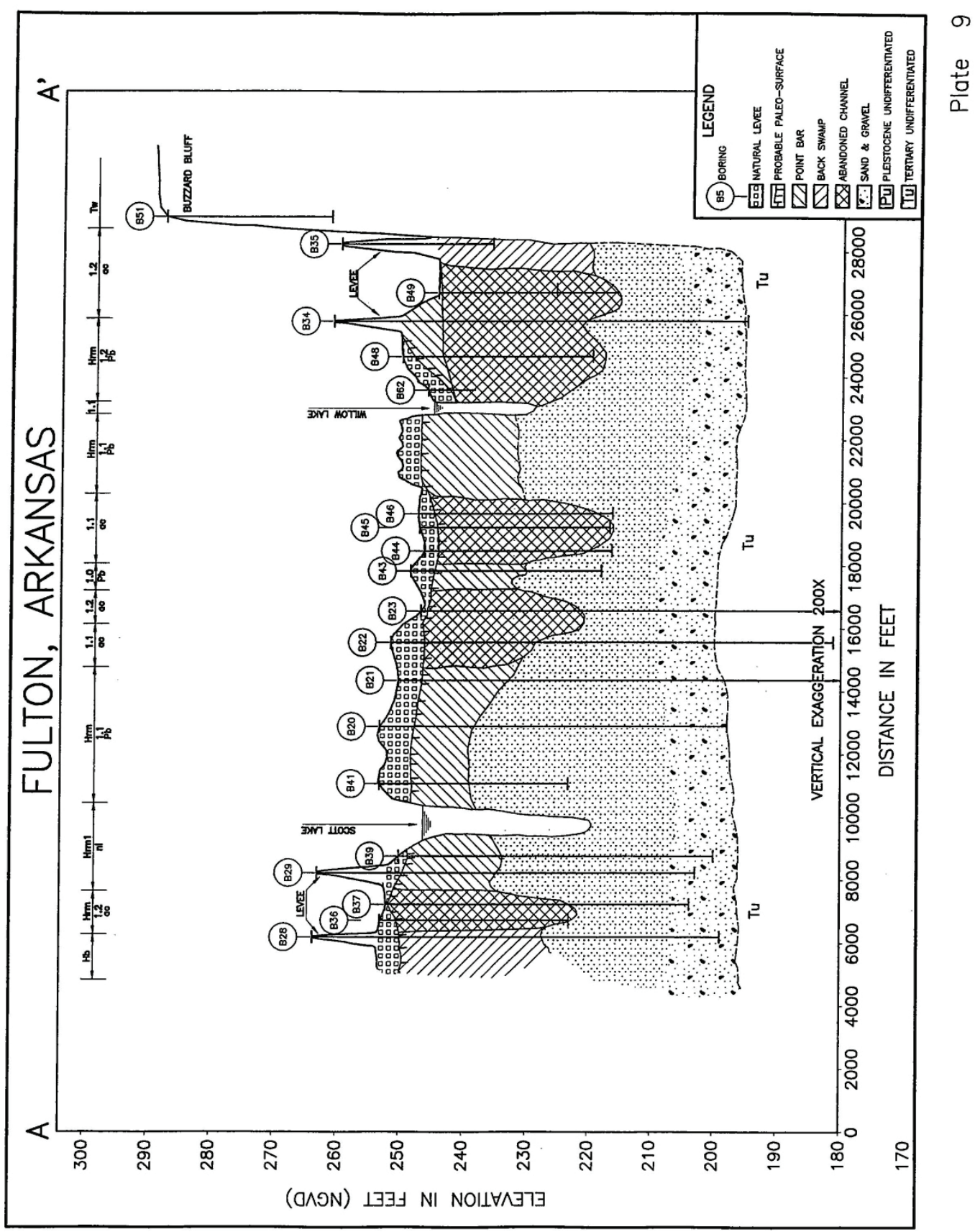




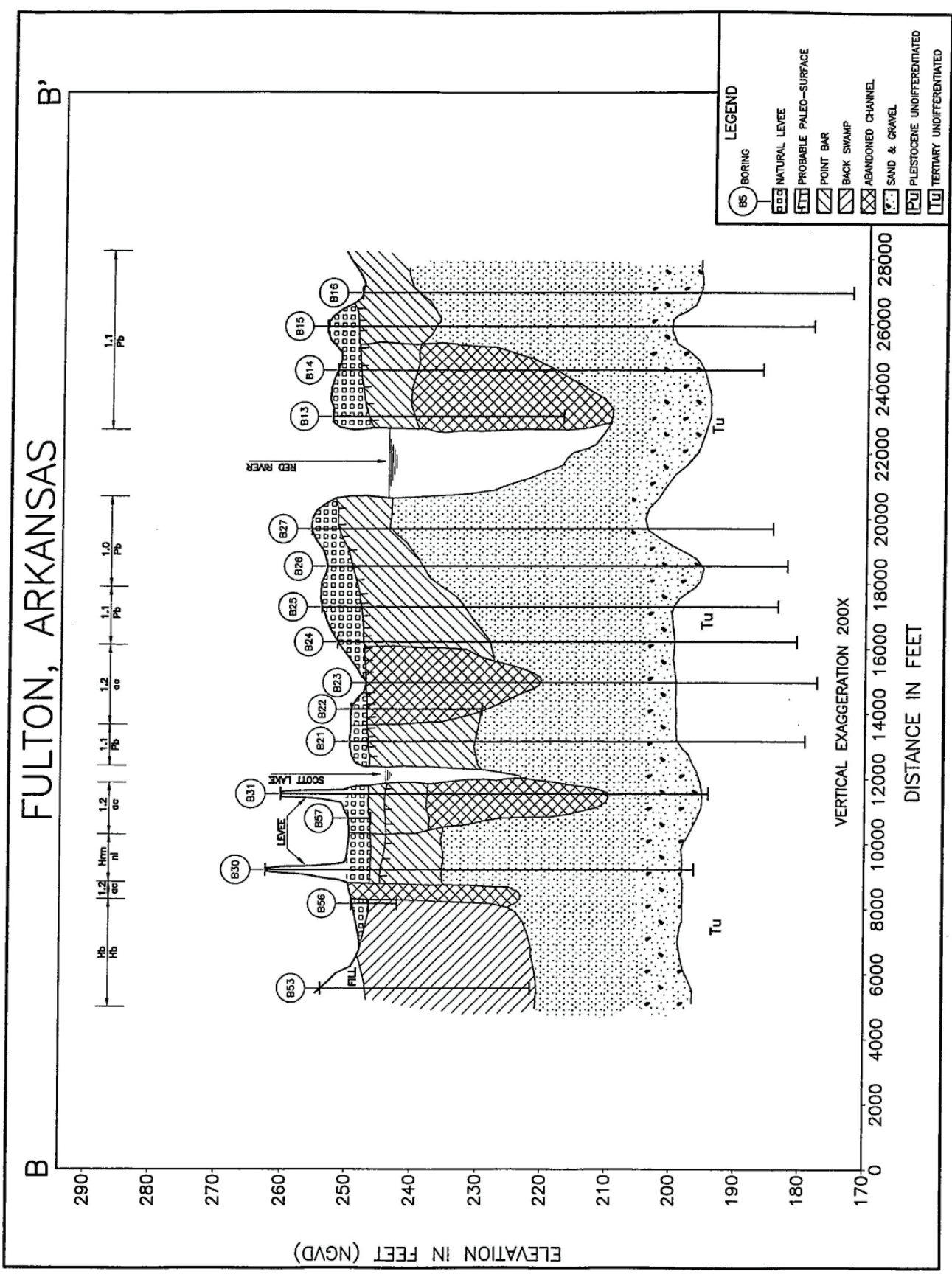




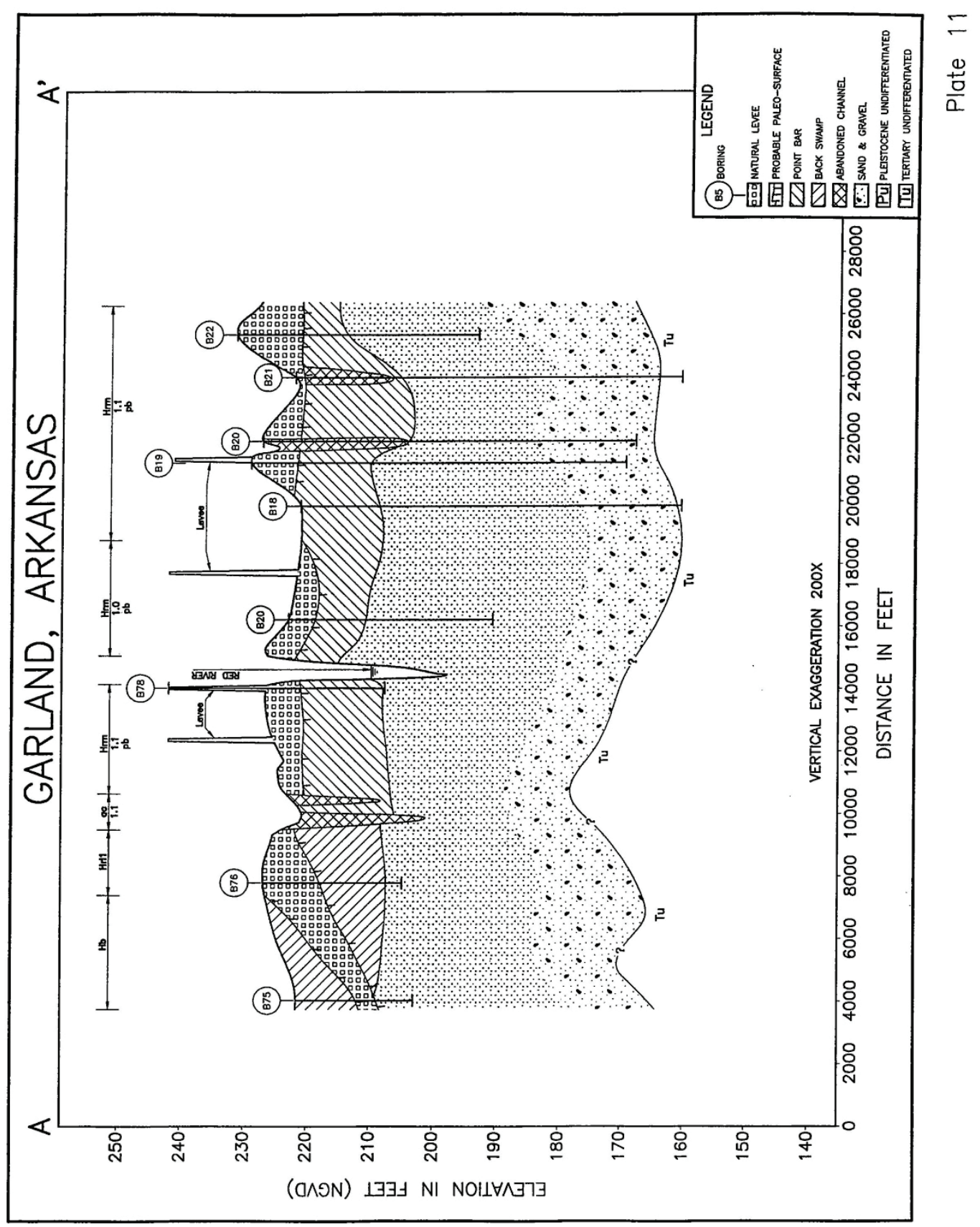




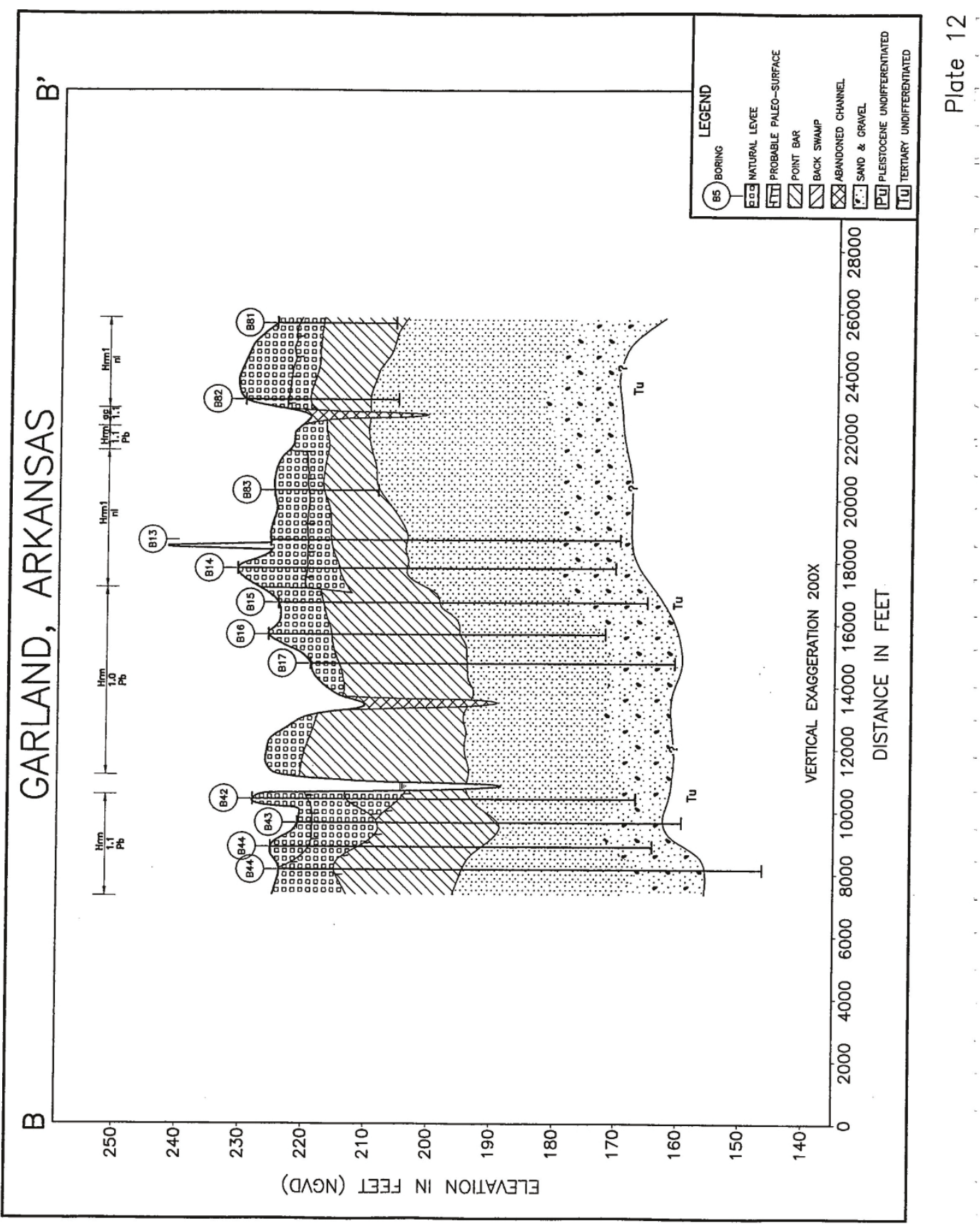




\section{Appendix C: Red River Boring Log Reference Table}

\section{Table of Contents}

Boyd Hill Quadrangle ................................................................. 72

Canfield Quadrangle ................................................................ 74

Doddridge Northeast Quadrangle .................................................. 75

Doddridge Southeast Quadrangle................................................. 76

Fouke Northeast Quadrangle............................................................. 77

Fulton Quadrangle .............................................................. 77

Garland Quadrangle..................................................................80

Spring Hill Quadrangle ............................................................ 81 


\begin{tabular}{|c|c|c|c|c|}
\hline $\begin{array}{l}\text { Usage Boring } \\
\text { No. }\end{array}$ & Reference Boring No. & Report Name & Mile No. & Quadrangle \\
\hline 1 & 374 L-5 & Kenny Revetment & 374 & Boyd Hill \\
\hline 2 & 374 L-6 & Corps of Engineers New Orleans & 374 & Boyd Hill \\
\hline 3 & 374 L-7 & Corps of Engineers New Orleans & 374 & Boyd Hill \\
\hline 4 & 374 L-8 & Corps of Engineers New Orleans & 374 & Boyd Hill \\
\hline 5 & 374 L-9 & Corps of Engineers New Orleans & 374 & Boyd Hill \\
\hline 6 & 374 L-10 & Corps of Engineers New Orleans & 374 & Boyd Hill \\
\hline 7 & $380 \mathrm{R}-1$ & Mays Lake Realignment & $381.5-377$. & Boyd Hill \\
\hline 8 & $380 \mathrm{R}-2$ & Corps of Engineers New Orleans & 381.5-377. & Boyd Hill \\
\hline 9 & $380 \mathrm{R}-3$ & Corps of Engineers New Orleans & $381.5-377$. & Boyd Hill \\
\hline 10 & $380 \mathrm{R}-4$ & Corps of Engineers New Orleans & 381.5-377. & Boyd Hill \\
\hline 11 & $384 \mathrm{R}-1$ & Red Lake Revetment & 384 & Boyd Hill \\
\hline 12 & $384 \mathrm{R}-1 \mathrm{U}$ & Corps of Engineers New Orleans & 384 & Boyd Hill \\
\hline 13 & $384 \mathrm{R}-2$ & Corps of Engineers New Orleans & 384 & Boyd Hill \\
\hline 14 & 384 R-3 & Corps of Engineers New Orleans & 384 & Boyd Hill \\
\hline 15 & 384 R-2U & Corps of Engineers New Orleans & 384 & Boyd Hill \\
\hline 16 & 384 R-4 & Corps of Engineers New Orleans & 384 & Boyd Hill \\
\hline 17 & 373 R-3 & Kenny Revetment & 374 & Boyd Hill \\
\hline 18 & $373 \mathrm{R}-4$ & Corps of Engineers New Orleans & 374 & Boyd Hill \\
\hline 19 & 373 R-5 & Corps of Engineers New Orleans & 374 & Boyd Hill \\
\hline 20 & 373 R-6 & Corps of Engineers New Orleans & 374 & Boyd Hill \\
\hline 21 & $373 \mathrm{R}-7$ & Corps of Engineers New Orleans & 374 & Boyd Hill \\
\hline 22 & 373 R-8 & Corps of Engineers New Orleans & 374 & Boyd Hill \\
\hline 23 & $380 \mathrm{R}-2$ & Beck Revetment & 380 & Boyd Hill \\
\hline 24 & $380 \mathrm{R}-3$ & Corps of Engineers New Orleans & 380 & Boyd Hill \\
\hline 25 & $380 \mathrm{R}-4$ & Corps of Engineers New Orleans & 380 & Boyd Hill \\
\hline 26 & $380 \mathrm{R}-5$ & Corps of Engineers New Orleans & 380 & Boyd Hill \\
\hline 27 & $380 \mathrm{R}-6$ & Corps of Engineers New Orleans & 380 & Boyd Hill \\
\hline 28 & $380 \mathrm{R}-7$ & Corps of Engineers New Orleans & 380 & Boyd Hill \\
\hline 29 & $380 \mathrm{R}-8$ & Corps of Engineers New Orleans & 380 & Boyd Hill \\
\hline 30 & $380 \mathrm{R}-9$ & Corps of Engineers New Orleans & 380 & Boyd Hill \\
\hline 31 & 383 L-1 & Boyd Revetment & 383.1 & Boyd Hill \\
\hline 32 & $383 \mathrm{~L}-2$ & Corps of Engineers New Orleans & 383.1 & Boyd Hill \\
\hline 33 & 383 L-3 & Corps of Engineers New Orleans & 383.1 & Boyd Hill \\
\hline 34 & $383 \mathrm{~L}-4$ & Corps of Engineers New Orleans & 383.1 & Boyd Hill \\
\hline 35 & 383 L-5 & Corps of Engineers New Orleans & 383.1 & Boyd Hill \\
\hline 36 & $383 \mathrm{~L}-6$ & Corps of Engineers New Orleans & 383.1 & Boyd Hill \\
\hline 37 & 708 & Arkansas Lignite Investigations & $1-82$ & Boyd Hill \\
\hline 38 & 709 & Info. Cir. 28-C 1985 & $1-82$ & Boyd Hill \\
\hline 39 & 258 & Info. Cir. 28-C 1985 & Rt. 29 & Boyd Hill \\
\hline 40 & 257 & Info. Cir. 28-C 1985 & Rt. 29 & Boyd Hill \\
\hline 41 & Bridge No. 5617 & Arkansas State Highway Commission & Rt. 29 & Boyd Hill \\
\hline 42 & W-7 & Geological Investigation Map & $n / a$ & Boyd Hill \\
\hline 43 & W-8 & USGS 1:62500 Lewisville & $n / a$ & Boyd Hill \\
\hline
\end{tabular}




\begin{tabular}{|c|c|c|c|c|}
\hline $\begin{array}{l}\text { Usage Boring } \\
\text { No. }\end{array}$ & Reference Boring No. & Report Name & Mile No. & Quadrangle \\
\hline 44 & W-18 & USGS 1:62500 Lewisville & $n / a$ & Boyd Hill \\
\hline 45 & B5 & Item 5 & $n / a$ & Boyd Hill \\
\hline 46 & B9 & Item 5 & $n / a$ & Boyd Hill \\
\hline 47 & B10 & Item 5 & $n / a$ & Boyd Hill \\
\hline 48 & B11 & Item 5 & $n / a$ & Boyd Hill \\
\hline 49 & B12 & Item 5 & $n / a$ & Boyd Hill \\
\hline 50 & B13 & Item 5 & $n / a$ & Boyd Hill \\
\hline 51 & B14 & Item 5 & $n / a$ & Boyd Hill \\
\hline 52 & B15 & Item 5 & $n / a$ & Boyd Hill \\
\hline 53 & B16 & Item 5 & $n / a$ & Boyd Hill \\
\hline 54 & B17 & Item 5 & n/a & Boyd Hill \\
\hline 55 & B18 & Item 5 & $n / a$ & Boyd Hill \\
\hline 56 & B19 & Item 5 & $n / a$ & Boyd Hill \\
\hline 57 & B20 & Item 5 & $n / a$ & Boyd Hill \\
\hline 58 & B21 & Item 5 & $n / a$ & Boyd Hill \\
\hline 59 & B22 & Item 5 & n/a & Boyd Hill \\
\hline 60 & B23 & Item 5 & $n / a$ & Boyd Hill \\
\hline 61 & B24 & Item 5 & $n / a$ & Boyd Hill \\
\hline 62 & B25 & Item 5 & n/a & Boyd Hill \\
\hline 63 & B26 & Item 5 & $n / a$ & Boyd Hill \\
\hline 64 & B27 & Item 5 & $n / a$ & Boyd Hill \\
\hline 65 & B28 & Item 5 & n/a & Boyd Hill \\
\hline 66 & B29 & Item 5 & $n / a$ & Boyd Hill \\
\hline 67 & B30 & Item 5 & n/a & Boyd Hill \\
\hline 68 & B31 & Item 5 & n/a & Boyd Hill \\
\hline 69 & B32 & Item 5 & $n / a$ & Boyd Hill \\
\hline 70 & B33 & Item 5 & $n / a$ & Boyd Hill \\
\hline 71 & B34 & Item 5 & $n / a$ & Boyd Hill \\
\hline 72 & B35 & Item 5 & $n / a$ & Boyd Hill \\
\hline 73 & B36 & Item 5 & $n / a$ & Boyd Hill \\
\hline 74 & B37 & Item 5 & $n / a$ & Boyd Hill \\
\hline 75 & B38 & Item 5 & $n / a$ & Boyd Hill \\
\hline 76 & B39 & Item 5 & $n / a$ & Boyd Hill \\
\hline 77 & B40 & Item 5 & $n / a$ & Boyd Hill \\
\hline 78 & B1 & Item 9 Below Dension Dam & $n / a$ & Boyd Hill \\
\hline 79 & B2 & Item 9 Below Dension Dam & $n / a$ & Boyd Hill \\
\hline 80 & B3 & Item 9 Below Dension Dam & $n / a$ & Boyd Hill \\
\hline 81 & B4 & Item 9 Below Dension Dam & $n / a$ & Boyd Hill \\
\hline 82 & B5 & Item 9 Below Dension Dam & n/a & Boyd Hill \\
\hline 83 & B6 & Item 9 Below Dension Dam & $n / a$ & Boyd Hill \\
\hline 84 & B7 & Item 9 Below Dension Dam & $n / a$ & Boyd Hill \\
\hline 85 & B8 & Item 9 Below Dension Dam & $n / a$ & Boyd Hill \\
\hline 86 & B9 & Item 9 Below Dension Dam & $n / a$ & Boyd Hill \\
\hline
\end{tabular}




\begin{tabular}{|c|c|c|c|c|}
\hline $\begin{array}{l}\text { Usage Boring } \\
\text { No. }\end{array}$ & Reference Boring No. & Report Name & Mile No. & Quadrangle \\
\hline 87 & B10 & Item 9 Below Dension Dam & $n / a$ & Boyd Hill \\
\hline 88 & R23 & Whitney Autin Soil Borings & $n / a$ & Boyd Hill \\
\hline 89 & R44 & Louisiana State University & $n / a$ & Boyd Hill \\
\hline 90 & R33 & Louisiana State University & $n / a$ & Boyd Hill \\
\hline 91 & R32 & Louisiana State University & $n / a$ & Boyd Hill \\
\hline 92 & R36 & Louisiana State University & $n / a$ & Boyd Hill \\
\hline 93 & R37 & Louisiana State University & $n / a$ & Boyd Hill \\
\hline 94 & R40 & Louisiana State University & $n / a$ & Boyd Hill \\
\hline 95 & R38 & Louisiana State University & $n / a$ & Boyd Hill \\
\hline 96 & R46 & Louisiana State University & $n / a$ & Boyd Hill \\
\hline 97 & R47 & Louisiana State University & $n / a$ & Boyd Hill \\
\hline 98 & R45 & Louisiana State University & $n / a$ & Boyd Hill \\
\hline 99 & R41 & Louisiana State University & $n / a$ & Boyd Hill \\
\hline 100 & R43 & Louisiana State University & $n / a$ & Boyd Hill \\
\hline 101 & R39 & Louisiana State University & $n / a$ & Boyd Hill \\
\hline 102 & R42 & Louisiana State University & $n / a$ & Boyd Hill \\
\hline 1 & 352 L-1 & Maniece Bayou Revetment & 352.5 & Canfield \\
\hline 2 & $352 \mathrm{~L}-2$ & Corps of Engineers New Orleans & 352.5 & Canfield \\
\hline 3 & $352 \mathrm{~L}-3$ & Corps of Engineers New Orleans & 352.5 & Canfield \\
\hline 4 & 352 L-4 & Corps of Engineers New Orleans & 352.5 & Canfield \\
\hline 5 & 352 L-5 & Corps of Engineers New Orleans & 352.5 & Canfield \\
\hline 6 & 352 L-6 & Corps of Engineers New Orleans & 352.5 & Canfield \\
\hline 7 & $350 \mathrm{R}-4$ & Corps of Engineers New Orleans & 350 & Canfield \\
\hline 8 & $350 \mathrm{R}-5$ & Corps of Engineers New Orleans & 350 & Canfield \\
\hline 9 & $350 \mathrm{R}-6$ & Corps of Engineers New Orleans & 350 & Canfield \\
\hline 10 & $350 \mathrm{R}-7$ & Corps of Engineers New Orleans & 350 & Canfield \\
\hline 11 & $350 \mathrm{R}-8$ & Corps of Engineers New Orleans & 350 & Canfield \\
\hline 12 & 350 R-9 & Corps of Engineers New Orleans & 350 & Canfield \\
\hline 13 & $350 \mathrm{R}-100$ & Corps of Engineers New Orleans & 350 & Canfield \\
\hline 14 & $350 \mathrm{R}-11$ & Corps of Engineers New Orleans & 350 & Canfield \\
\hline 15 & Bridge No. 450 & Arkansas Highway Comm.-Dooley Creek & Rt.29 & Canfield \\
\hline 16 & $355.5 \mathrm{~L}-1$ & Swan Lake Revetment & 355.5 & Canfield \\
\hline 17 & $355.5 \mathrm{~L}-2$ & Corps of Engineers New Orleans & 355.5 & Canfield \\
\hline 18 & $355.5 \mathrm{~L}-3$ & Corps of Engineers New Orleans & 355.5 & Canfield \\
\hline 19 & $355.5 \mathrm{~L}-4$ & Corps of Engineers New Orleans & 355.5 & Canfield \\
\hline 20 & SL-1-83U & Corps of Engineers New Orleans & 355.5 & Canfield \\
\hline 21 & SL-2-83U & Corps of Engineers New Orleans & 355.5 & Canfield \\
\hline 22 & 788 & Arkansas Lignite Investigation & $n / a$ & Canfield \\
\hline 23 & 787 & Info. Cir. 28-C 1985 & $n / a$ & Canfield \\
\hline 24 & $786 / 1154$ & Info. Cir. 28-C 1985 & $n / a$ & Canfield \\
\hline 25 & W-13 & Geological Investigation Map & $n / a$ & Canfield \\
\hline 26 & W-4 & USGS 1:62500 Bradley & $n / a$ & Canfield \\
\hline 27 & W-8 & USGS 1:62500 Bradley & $n / a$ & Canfield \\
\hline
\end{tabular}




\begin{tabular}{|c|c|c|c|c|}
\hline $\begin{array}{l}\text { Usage Boring } \\
\text { No. }\end{array}$ & Reference Boring No. & Report Name & Mile No. & Quadrangle \\
\hline 28 & B35 & Item 9 Below Dension Dam & $n / a$ & Canfield \\
\hline 29 & B36 & Item 9 Below Dension Dam & $n / a$ & Canfield \\
\hline 30 & B37 & Item 9 Below Dension Dam & $n / a$ & Canfield \\
\hline 31 & B38 & Item 9 Below Dension Dam & $n / a$ & Canfield \\
\hline 32 & B39 & Item 9 Below Dension Dam & $n / a$ & Canfield \\
\hline 33 & B40 & Item 9 Below Dension Dam & $n / a$ & Canfield \\
\hline 38 & GL-10-84 & Goose Lake Realignment & 348 & Canfield \\
\hline 39 & GL-1-84U & Corps of Engineers New Orleans & 348 & Canfield \\
\hline 40 & GL-11-84 & Corps of Engineers New Orleans & 348 & Canfield \\
\hline 41 & GL-2-84U & Corps of Engineers New Orleans & 348 & Canfield \\
\hline 42 & GL-3-84U & Corps of Engineers New Orleans & 348 & Canfield \\
\hline 43 & GL-12-84 & Corps of Engineers New Orleans & 348 & Canfield \\
\hline 44 & GL-4-84U & Corps of Engineers New Orleans & 348 & Canfield \\
\hline 45 & GL-13-84 & Corps of Engineers New Orleans & 348 & Canfield \\
\hline 46 & GL-5-84U & Corps of Engineers New Orleans & 348 & Canfield \\
\hline 47 & GL-14-84U & Corps of Engineers New Orleans & 348 & Canfield \\
\hline 48 & GL-6-84U & Corps of Engineers New Orleans & 348 & Canfield \\
\hline 49 & GL-7-84U & Corps of Engineers New Orleans & 348 & Canfield \\
\hline 50 & GL-8-84U & Corps of Engineers New Orleans & 348 & Canfield \\
\hline 51 & GL-9-84U & Corps of Engineers New Orleans & 348 & Canfield \\
\hline 52 & GL-15-84 & Corps of Engineers New Orleans & 348 & Canfield \\
\hline 53 & GL-16-84 & Corps of Engineers New Orleans & 348 & Canfield \\
\hline 54 & GL-117-84 & Corps of Engineers New Orleans & 348 & Canfield \\
\hline 55 & R69 & Whitney Autin Soil Boring & 348 & Canfield \\
\hline 56 & R70 & Louisiana State University & 348 & Canfield \\
\hline 57 & R71 & Louisiana State University & 348 & Canfield \\
\hline 58 & R72 & Louisiana State University & 348 & Canfield \\
\hline 59 & R73 & Louisiana State University & 348 & Canfield \\
\hline 60 & R74 & Louisiana State University & 348 & Canfield \\
\hline 61 & R75 & Louisiana State University & 348 & Canfield \\
\hline 62 & R76 & Louisiana State University & 348 & Canfield \\
\hline 63 & R85 & Louisiana State University & 348 & Canfield \\
\hline 1 & DR-1-94U & Dickson Revetment & $343-346$ & Doddridge NE \\
\hline 2 & DR-2-94U & Corps of Engineers Vicksburg & $343-346$ & Doddridge NE \\
\hline 3 & DR-3-94U & Corps of Engineers Vicksburg & $343-346$ & Doddridge NE \\
\hline 4 & DR-4-94U & Corps of Engineers Vicksburg & $343-346$ & Doddridge NE \\
\hline 4 & DR-5-94U & Corps of Engineers Vicksburg & $343-346$ & Doddridge NE \\
\hline 6 & DR-6-94U & Corps of Engineers Vicksburg & $343-346$ & Doddridge NE \\
\hline 7 & DR-7-94U & Corps of Engineers Vicksburg & $343-346$ & Doddridge NE \\
\hline 8 & DR-8-94U & Corps of Engineers Vicksburg & $343-346$ & Doddridge NE \\
\hline 9 & DR-9-94fU & Corps of Engineers Vicksburg & $343-346$ & Doddridge NE \\
\hline 10 & DR-10-94U & Corps of Engineers Vicksburg & $343-346$ & Doddridge NE \\
\hline 11 & DR-11-94U & Corps of Engineers Vicksburg & $343-346$ & Doddridge NE \\
\hline
\end{tabular}




\begin{tabular}{|c|c|c|c|c|}
\hline $\begin{array}{l}\text { Usage Boring } \\
\text { No. }\end{array}$ & Reference Boring No. & Report Name & Mile No. & Quadrangle \\
\hline 12 & BBR-1-88 & Brown Bend Realignment & 339-342 & Doddridge NE \\
\hline 13 & BBR-2-88 & Brown Bend Realignment & $339-342$ & Doddridge NE \\
\hline 14 & BBR-3-88 & Brown Bend Realignment & $339-342$ & Doddridge NE \\
\hline 15 & BBR-4-88 & Brown Bend Realignment & $339-342$ & Doddridge NE \\
\hline 16 & BBR-5-88 & Brown Bend Realignment & $339-342$ & Doddridge NE \\
\hline 17 & BBR-6-88 & Brown Bend Realignment & $339-342$ & Doddridge NE \\
\hline 18 & OR-1-85 & Oak Revetment Extension & $348-346$ & Doddridge NE \\
\hline 19 & OR-2-85 & Corps of Engineers Vicksburg & $348-346$ & Doddridge NE \\
\hline 20 & OR-3-85 & Corps of Engineers Vicksburg & $348-346$ & Doddridge NE \\
\hline 21 & OR-4-85 & Corps of Engineers Vicksburg & $348-346$ & Doddridge NE \\
\hline 22 & 803 & Arkansas Lignite Investigations & $n / a$ & Doddridge NE \\
\hline 23 & 804 & Info. Cir. 28C 1985 & $n / a$ & Doddridge NE \\
\hline 24 & W-1 & Geological Investigation Map & $n / a$ & Doddridge NE \\
\hline 25 & W-9 & USGS 1:62500-Doddridge & $n / a$ & Doddridge NE \\
\hline 26 & W-10 & USGS 1:62500-Doddridge & $n / a$ & Doddridge NE \\
\hline 27 & W-13 & USGS 1:62500-Doddridge & $n / a$ & Doddridge NE \\
\hline 28 & W-8 & USGS 1:62500-Doddridge & $n / a$ & Doddridge NE \\
\hline 29 & W-6 & USGS 1:62500-Doddridge & $n / a$ & Doddridge NE \\
\hline 30 & R54 & Whitney Autin Soil Borings & $n / a$ & Doddridge NE \\
\hline 31 & R55 & Louisiana State University & $n / a$ & Doddridge NE \\
\hline 32 & R56 & Louisiana State University & $n / a$ & Doddridge NE \\
\hline 33 & R57 & Louisiana State University & $n / a$ & Doddridge NE \\
\hline 34 & R58 & Louisiana State University & $n / a$ & Doddridge NE \\
\hline 35 & R59 & Louisiana State University & $n / a$ & Doddridge NE \\
\hline 36 & R60 & Louisiana State University & $n / a$ & Doddridge NE \\
\hline 37 & R61 & Louisiana State University & $n / a$ & Doddridge NE \\
\hline 38 & R62 & Louisiana State University & $n / a$ & Doddridge NE \\
\hline 39 & R77 & Louisiana State University & $n / a$ & Doddridge NE \\
\hline 40 & R78 & Louisiana State University & $n / a$ & Doddridge NE \\
\hline 41 & R79 & Louisiana State University & $n / a$ & Doddridge NE \\
\hline 1 & 805 & Arkansas Lignite Investigation & $n / a$ & Doddridge SE \\
\hline 2 & 1164 & Info. Cir. 28-C 1985 & $n / a$ & Doddridge SE \\
\hline 3 & 806 & Info. Cir. 28-C 1985 & $n / a$ & Doddridge SE \\
\hline 4 & 807 & Info. Cir. 28-C 1985 & $n / a$ & Doddridge SE \\
\hline 5 & $225 \mathrm{~A}$ & Info. Cir 28-C 1985 & $n / a$ & Doddridge SE \\
\hline 6 & $328 \mathrm{R}-7$ & Missionary Revetment & 326.4 & Doddridge SE \\
\hline 7 & $328 \mathrm{R}-8$ & Corps of Engineers New Orleans & 326.4 & Doddridge SE \\
\hline 8 & $328 \mathrm{R}-9$ & October 1977 & 326.4 & Doddridge SE \\
\hline 9 & $328 \mathrm{R}-10$ & October 1977 & 326.4 & Doddridge SE \\
\hline 10 & $328 \mathrm{R}-11$ & October 1977 & 326.4 & Doddridge SE \\
\hline 11 & $328 \mathrm{R}-1$ & Halfmoon Revetment & $329-325$ & Doddridge SE \\
\hline 12 & $328 \mathrm{R}-2$ & Corps of Engineers New Orleans & $329-325$ & Doddridge SE \\
\hline 13 & $328 \mathrm{R}-3$ & Corps of Engineers New Orleans & $329-325$ & Doddridge SE \\
\hline
\end{tabular}




\begin{tabular}{|c|c|c|c|c|}
\hline $\begin{array}{l}\text { Usage Boring } \\
\text { No. }\end{array}$ & Reference Boring No. & Report Name & Mile No. & Quadrangle \\
\hline 14 & $328 \mathrm{R}-4$ & Corps of Engineers New Orleans & $329-325$ & Doddridge SE \\
\hline 15 & $335 \mathrm{R}-5$ & Spring Bank Revetment & 335.5 & Doddridge SE \\
\hline 16 & $335 \mathrm{R}-6$ & Corps of Engineers New Orleans & 335.5 & Doddridge SE \\
\hline 17 & $335 \mathrm{R}-7$ & August 1979 & 335.5 & Doddridge SE \\
\hline 18 & $335 \mathrm{R}-8$ & August 1979 & 335.5 & Doddridge SE \\
\hline 19 & W-3 & Geological Investigation Map & $n / a$ & Doddridge SE \\
\hline 20 & W-2 & USGS 1:62500 Doddridge & $n / a$ & Doddridge SE \\
\hline 1 & 701 & Arkansas Lignite Investigation & $n / a$ & Fouke NE \\
\hline 2 & 702 & Info. Cir. 28-C 1985 & $n / a$ & Fouke NE \\
\hline 3 & 703 & Info. Cir. 28-C 1985 & $n / a$ & Fouke NE \\
\hline 4 & 704 & Info. Cir. 28-C 1985 & $n / a$ & Fouke NE \\
\hline 5 & 705 & Info. Cir. 28-C 1985 & $n / a$ & Fouke NE \\
\hline 6 & 706 & Info. Cir. 28-C 1985 & $n / a$ & Fouke NE \\
\hline 7 & 707 & Info. Cir. 28-C 1985 & $n / a$ & Fouke NE \\
\hline 8 & Bridge No. 860 & Arkansas Highway Comm.-McKinney Bay & Rt. 82 & Fouke NE \\
\hline 9 & R25 & Whitney Autin Soil Borings & $n / a$ & Fouke NE \\
\hline 10 & R26 & Louisiana State University & $n / a$ & Fouke NE \\
\hline 11 & W-6 & $\begin{array}{l}\text { Geological Investigation Map } \\
\text { USGS 1:62500 Fouke }\end{array}$ & $n / a$ & Fouke NE \\
\hline 12 & W-3 & $\begin{array}{l}\text { Geological Investigation Map } \\
\text { USGS 1:62500 Fouke }\end{array}$ & $n / a$ & Fouke NE \\
\hline 13 & W-4 & $\begin{array}{l}\text { Geological Investigation Map } \\
\text { USGS 1:62500 Fouke }\end{array}$ & $n / a$ & Fouke NE \\
\hline 14 & W-9 & $\begin{array}{l}\text { Geological Investigation Map } \\
\text { SGS 1:62500 Fouke }\end{array}$ & $n / a$ & Fouke NE \\
\hline 15 & $\mathrm{R} 28$ & Whitney Autin Soil Borings & $n / a$ & Fouke NE \\
\hline 16 & R27 & Louisiana State University & $n / a$ & Fouke NE \\
\hline 17 & R34 & Louisiana State University & $n / a$ & Fouke NE \\
\hline 18 & R35 & Louisiana State University & $n / a$ & Fouke NE \\
\hline 1 & FR-1 & RR Waterway - Fulton Revetment & $401.7-402.3$ & Fulton \\
\hline 2 & FR-2 & Corps of Engineers - April 1987 & $401.7-402.3$ & Fulton \\
\hline 3 & OR-1 & RR Waterway-Mo Pac 30 Revetment & 403 & Fulton \\
\hline 4 & OR-2 & Corps of Engineers Soils Report & 403 & Fulton \\
\hline 5 & OR-3 & August 1983 & 403 & Fulton \\
\hline 6 & OR-4 & August 1983 & 403 & Fulton \\
\hline 7 & OR-5 & August 1983 & 403 & Fulton \\
\hline 8 & OR-6 & August 1983 & 403 & Fulton \\
\hline 9 & OR-7 & August 1983 & 403 & Fulton \\
\hline 10 & OR-8 & August 1983 & 403 & Fulton \\
\hline 11 & 397L-1 & RR Waterway - Bushy Revetment & 397 & Fulton \\
\hline 12 & $397 L-2$ & Corps of Engineers Soils Report & 397 & Fulton \\
\hline 13 & 397L-3 & November 1978 & 397 & Fulton \\
\hline 14 & $397 L-4$ & November 1978 & 397 & Fulton \\
\hline
\end{tabular}




\begin{tabular}{|c|c|c|c|c|}
\hline $\begin{array}{l}\text { Usage Boring } \\
\text { No. }\end{array}$ & Reference Boring No. & Report Name & Mile No. & Quadrangle \\
\hline 15 & 397L-5 & November 1978 & 397 & Fulton \\
\hline 16 & 397L-6 & November 1978 & 397 & Fulton \\
\hline 17 & 397L-7 & November 1978 & 397 & Fulton \\
\hline 18 & 397L-8 & November 1978 & 397 & Fulton \\
\hline 19 & 398.2 R-1 & RR Waterway - Kuykendall Revetment & 397 to 399 & Fulton \\
\hline 20 & 398.2 R-2 & Corps of Engineers Soils Report & 397 to 399 & Fulton \\
\hline 21 & 398.2 R-3 & July 1983 & 397 to 399 & Fulton \\
\hline 22 & $398.2 \mathrm{R}-4$ & July 1983 & 397 to 399 & Fulton \\
\hline 23 & $398.2 \mathrm{R}-5$ & July 1983 & 397 to 399 & Fulton \\
\hline 24 & $398.2 \mathrm{R}-6$ & July 1983 & 397 to 399 & Fulton \\
\hline 25 & $398.2 \mathrm{R}-7$ & July 1983 & 397 to 399 & Fulton \\
\hline 26 & $398.2 \mathrm{R}-8$ & July 1983 & 397 to 399 & Fulton \\
\hline 27 & $398.2 \mathrm{R}-9$ & July 1983 & 397 to 399 & Fulton \\
\hline 28 & BDD4-1-94U & RR Below Dension Dam & $n / a$ & Fulton \\
\hline 29 & BDD4-2-94U & Corps of Engineers Vicksburg & $n / a$ & Fulton \\
\hline 30 & BDD4-3-94U & Maps and Boring Logs November 1994 & $n / a$ & Fulton \\
\hline 31 & BDD4-4-94U & Maps and Boring Logs November 1994 & $n / a$ & Fulton \\
\hline 32 & BDD4-5-94U & Maps and Boring Logs November 1994 & $n / a$ & Fulton \\
\hline 33 & BDD4-6-94U & Maps and Boring Logs November 1994 & $n / a$ & Fulton \\
\hline 34 & BDD4-7-94U & Maps and Boring Logs November 1994 & $n / a$ & Fulton \\
\hline 35 & BDD4-8-94U & Maps and Boring Logs November 1994 & $n / a$ & Fulton \\
\hline 36 & BDD4-1-94B & Maps and Boring Logs November 1994 & $n / a$ & Fulton \\
\hline 37 & BDD4-2-94B & Maps and Boring Logs November 1994 & $n / a$ & Fulton \\
\hline 38 & BDD4-3-94B & Maps and Boring Logs November 1994 & $n / a$ & Fulton \\
\hline 39 & BDD4-4-94B & Maps and Boring Logs November 1994 & $n / a$ & Fulton \\
\hline 40 & BDD4-5-94B & Maps and Boring Logs November 1994 & $n / a$ & Fulton \\
\hline 41 & BDD4-6-94B & Maps and Boring Logs November 1994 & $n / a$ & Fulton \\
\hline 42 & BDD4-6A-94B & Maps and Boring Logs November 1994 & $n / a$ & Fulton \\
\hline 43 & BDD4-7-94B & Maps and Boring Logs November 1994 & $n / a$ & Fulton \\
\hline 44 & BDD4-8-94B & Maps and Boring Logs November 1994 & $n / a$ & Fulton \\
\hline 45 & BDD4-9-94B & Maps and Boring Logs November 1994 & $n / a$ & Fulton \\
\hline 46 & BDD4-10-94B & Maps and Boring Logs November 1994 & $n / a$ & Fulton \\
\hline 47 & BDD4-11-94B & Maps and Boring Logs November 1994 & $n / a$ & Fulton \\
\hline 48 & BDD4-12-94B & Maps and Boring Logs November 1994 & $n / a$ & Fulton \\
\hline 49 & BDD4-13-94B & Maps and Boring Logs November 1994 & $n / a$ & Fulton \\
\hline 50 & BDD4-14-94B & Maps and Boring Logs November 1994 & n/a & Fulton \\
\hline 51 & BDD4-15-94B & Maps and Boring Logs November 1994 & $n / a$ & Fulton \\
\hline 52 & BR3797A & Arkansas State Highway Int. 30 & $1-30$ & Fulton \\
\hline 53 & BR3797B & pp 122-123, 8-27-63 & Gill. Ditch & Fulton \\
\hline 54 & $\mathrm{R}-1$ & Whitney Autin - Soil Borings & $n / a$ & Fulton \\
\hline 55 & R-2 & Louisiana State University & $n / a$ & Fulton \\
\hline 56 & R-3 & Louisiana State University & n/a & Fulton \\
\hline 57 & R-4 & Louisiana State University & $n / a$ & Fulton \\
\hline
\end{tabular}




\begin{tabular}{|c|c|c|c|c|}
\hline $\begin{array}{l}\text { Usage Boring } \\
\text { No. }\end{array}$ & Reference Boring No. & Report Name & Mile No. & Quadrangle \\
\hline 58 & R-5 & Louisiana State University & $n / a$ & Fulton \\
\hline 59 & R-6 & Louisiana State University & $n / a$ & Fulton \\
\hline 60 & R-7 & Louisiana State University & $n / a$ & Fulton \\
\hline 61 & R-8 & Louisiana State University & $n / a$ & Fulton \\
\hline 62 & R-9 & Louisiana State University & $n / a$ & Fulton \\
\hline 63 & R-10 & Louisiana State University & $n / a$ & Fulton \\
\hline 64 & R-11 & Louisiana State University & $n / a$ & Fulton \\
\hline 65 & $\mathrm{R}-12$ & Louisiana State University & $n / a$ & Fulton \\
\hline 66 & $\mathrm{R}-13$ & Louisiana State University & $n / a$ & Fulton \\
\hline 67 & R-14 & Louisiana State University & $n / a$ & Fulton \\
\hline 68 & R-15 & Louisiana State University & $n / a$ & Fulton \\
\hline 69 & R-16 & Louisiana State University & $n / a$ & Fulton \\
\hline 70 & R-17 & Louisiana State University & $n / a$ & Fulton \\
\hline 71 & R-18 & Louisiana State University & $n / a$ & Fulton \\
\hline 72 & R-19 & Louisiana State University & $n / a$ & Fulton \\
\hline 73 & R-20 & Louisiana State University & $n / a$ & Fulton \\
\hline 74 & R-21 & Louisiana State University & $n / a$ & Fulton \\
\hline 75 & $\mathrm{R}-22$ & Louisiana State University & $n / a$ & Fulton \\
\hline 76 & $\mathrm{AH}-2$ & Geological Investigation Map & $n / a$ & Fulton \\
\hline 77 & AH-4 & USGS Scale $1=62500$ & $n / a$ & Fulton \\
\hline 78 & AH-5 & USGS Scale $1=62500$ & $n / a$ & Fulton \\
\hline 79 & GS-8 & USGS Scale $1=62500$ & $n / a$ & Fulton \\
\hline 80 & BDD5-1-95G & RR Waterway Below Dension & $n / a$ & Fulton \\
\hline 81 & BDD5-2-95G & Dam - Item 5 & $n / a$ & Fulton \\
\hline 82 & BDD5-3-95G & Corps of Engineers Soils Report & $n / a$ & Fulton \\
\hline 83 & BDD5-4-95G & March 8, 1995 & $n / a$ & Fulton \\
\hline 84 & BDD5-5-95G & March 8, 1995 & $n / a$ & Fulton \\
\hline 85 & BDD5-6-95G & March 8, 1995 & $n / a$ & Fulton \\
\hline 86 & BDD5-7-95G & March 8, 1995 & $n / a$ & Fulton \\
\hline 87 & BDD5-8-95G & March 8, 1995 & $n / a$ & Fulton \\
\hline 88 & BDD3-5-94U & RR Waterway Below Dension & $n / a$ & Fulton \\
\hline 89 & BDD3-6-94U & Dam - Item 3 & $n / a$ & Fulton \\
\hline 90 & BDD3-7-94U & Corps of Engineers Soils Report & $n / a$ & Fulton \\
\hline 91 & BDD3-14-94B & October 1994 & $n / a$ & Fulton \\
\hline 92 & BDD3-15-94B & October 1994 & $n / a$ & Fulton \\
\hline 93 & BDD3-16-94B & October 1994 & $n / a$ & Fulton \\
\hline 94 & BDD3-17-94B & October 1994 & $n / a$ & Fulton \\
\hline 95 & BDD3-18-94B & October 1994 & n/a & Fulton \\
\hline 96 & BDD3-19-94B & October 1994 & n/a & Fulton \\
\hline 97 & BDD3-20-94B & October 1994 & n/a & Fulton \\
\hline 98 & BDD3-21-94B & October 1994 & $n / a$ & Fulton \\
\hline 99 & BDD3-22-94B & October 1994 & $n / a$ & Fulton \\
\hline 100 & R30 & Whitney Autin - Soil Borings & $n / a$ & Fulton \\
\hline
\end{tabular}




\begin{tabular}{|c|c|c|c|c|}
\hline $\begin{array}{l}\text { Usage Boring } \\
\text { No. }\end{array}$ & Reference Boring No. & Report Name & Mile No. & Quadrangle \\
\hline 101 & R31 & Louisiana State University & $n / a$ & Fulton \\
\hline 102 & R29 & Louisiana State University & $n / a$ & Fulton \\
\hline 103 & R86 & Louisiana State University & $n / a$ & Fulton \\
\hline 104 & R87 & Louisiana State University & $n / a$ & Fulton \\
\hline 42 & CL-1-87U & Candler Lake Revetment Extension & $365-364$ & Garland \\
\hline 43 & CL-2-87U & Corps of Engineers Vicksburg & $365-364$ & Garland \\
\hline 44 & CL-3-87U & Corps of Engineers Vicksburg & $365-364$ & Garland \\
\hline 45 & CL-4-87U & Corps of Engineers Vicksburg & $365-364$ & Garland \\
\hline 46 & B41 & Item 5 & $n / a$ & Garland \\
\hline 47 & B42 & Item 5 & $n / a$ & Garland \\
\hline 48 & B43 & Item 5 & n/a & Garland \\
\hline 49 & B44 & Item 5 & $n / a$ & Garland \\
\hline 50 & B45 & Item 5 & $n / a$ & Garland \\
\hline 51 & B11 & Item 9 Below Dension Dam & $n / a$ & Garland \\
\hline 52 & B12 & Item 9 Below Dension Dam & $n / a$ & Garland \\
\hline 53 & B13 & Item 9 Below Dension Dam & $n / a$ & Garland \\
\hline 54 & B14 & Item 9 Below Dension Dam & $n / a$ & Garland \\
\hline 55 & & Item 9 Below Dension Dam & $n / a$ & Garland \\
\hline 56 & B15 & Item 9 Below Dension Dam & $n / a$ & Garland \\
\hline 57 & B16 & Item 9 Below Dension Dam & $n / a$ & Garland \\
\hline 58 & B17 & Item 9 Below Dension Dam & $n / a$ & Garland \\
\hline 59 & B18 & Item 9 Below Dension Dam & $n / a$ & Garland \\
\hline 60 & B19 & Item 9 Below Dension Dam & $n / a$ & Garland \\
\hline 61 & B20 & Item 9 Below Dension Dam & n/a & Garland \\
\hline 62 & B21 & Item 9 Below Dension Dam & n/a & Garland \\
\hline 63 & B22 & Item 9 Below Dension Dam & $n / a$ & Garland \\
\hline 64 & B23 & Item 9 Below Dension Dam & $n / a$ & Garland \\
\hline 65 & B24 & Item 9 Below Dension Dam & $n / a$ & Garland \\
\hline 66 & B25 & Item 9 Below Dension Dam & $n / a$ & Garland \\
\hline 67 & B26 & Item 9 Below Dension Dam & $n / a$ & Garland \\
\hline 68 & B27 & Item 9 Below Dension Dam & $n / a$ & Garland \\
\hline 69 & B28 & Item 9 Below Dension Dam & $n / a$ & Garland \\
\hline 70 & B29 & Item 9 Below Dension Dam & $n / a$ & Garland \\
\hline 71 & B30 & Item 9 Below Dension Dam & $n / a$ & Garland \\
\hline 72 & B31 & Item 9 Below Dension Dam & $n / a$ & Garland \\
\hline 73 & B32 & Item 9 Below Dension Dam & $n / a$ & Garland \\
\hline 74 & B34 & Item 9 Below Dension Dam & $n / a$ & Garland \\
\hline 75 & R48 & Whitney Autin LSU Soil Borings & $n / a$ & Garland \\
\hline 76 & R49 & Whitney Autin LSU Soil Borings & n/a & Garland \\
\hline 77 & R50 & Whitney Autin LSU Soil Borings & $n / a$ & Garland \\
\hline 78 & R51 & Whitney Autin LSU Soil Borings & $n / a$ & Garland \\
\hline 79 & R52 & Whitney Autin LSU Soil Borings & $n / a$ & Garland \\
\hline 80 & R53 & Whitney Autin LSU Soil Borings & $n / a$ & Garland \\
\hline
\end{tabular}




\begin{tabular}{|l|l|l|l|l|}
\hline $\begin{array}{l}\text { Usage Boring } \\
\text { No. }\end{array}$ & Reference Boring No. & Report Name & Mile No. & Quadrangle \\
\hline 81 & R63 & Whitney Autin LSU Soil Borings & n/a & Garland \\
\hline 82 & R64 & Whitney Autin LSU Soil Borings & n/a & Garland \\
\hline 83 & R65 & Whitney Autin LSU Soil Borings & n/a & Garland \\
\hline 84 & R66 & Whitney Autin LSU Soil Borings & n/a & Garland \\
\hline 84 & R67 & Whitney Autin LSU Soil Borings & n/a & Garland \\
\hline 86 & R68 & Whitney Autin LSU Soil Borings & n/a & Garland \\
\hline 1 & 252 & Arkansas Lignite Investigation & n/a & Spring Hill \\
\hline 2 & 1168 & Info. Cir. 28-C 1985 & n/a & Spring Hill \\
\hline 3 & 251 & Info. Cir. 28-C 1985 & n/a & Spring Hill \\
\hline 4 & 250 & Info. Cir. 28-C 1985 & n/a & Spring Hill \\
\hline 5 & 249 & Info. Cir. 28-C 1985 & n/a & Spring Hill \\
\hline 6 & 248 & Info. Cir. 28-C 1985 & n/a & Spring Hill \\
\hline 7 & SA-1 & Geological Investigation Map-Hop & n/a & Spring Hill \\
\hline 8 & 390 R-3 & Hervey Revetment & 389.2 & Spring Hill \\
\hline 9 & 390 R-4 & Corps of Engineers New Orleans & 389.2 & Spring Hill \\
\hline 10 & 390 R-5 & March 1977 & 389.2 & Spring Hill \\
\hline 11 & Bridge No. 6127 & Arkansas State Highway Comm.-Goss Creek & Rt. 174 & Spring Hill \\
\hline
\end{tabular}




\section{Appendix D: Soil Borings}




$$
\mathrm{R}-01
$$

Sec 2 T14S R27W

Fulton

11-14-1994

G.S.E. 264.1

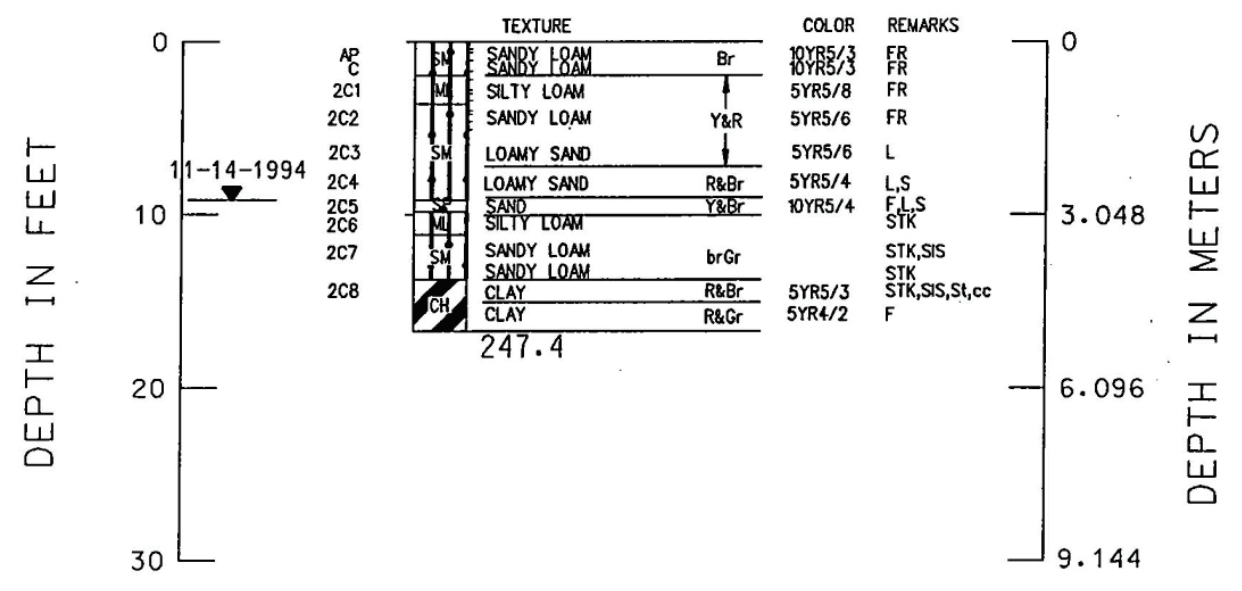

RED RIVER FULTON, ARKANSAS TO LOUISIANA STATE LINE 


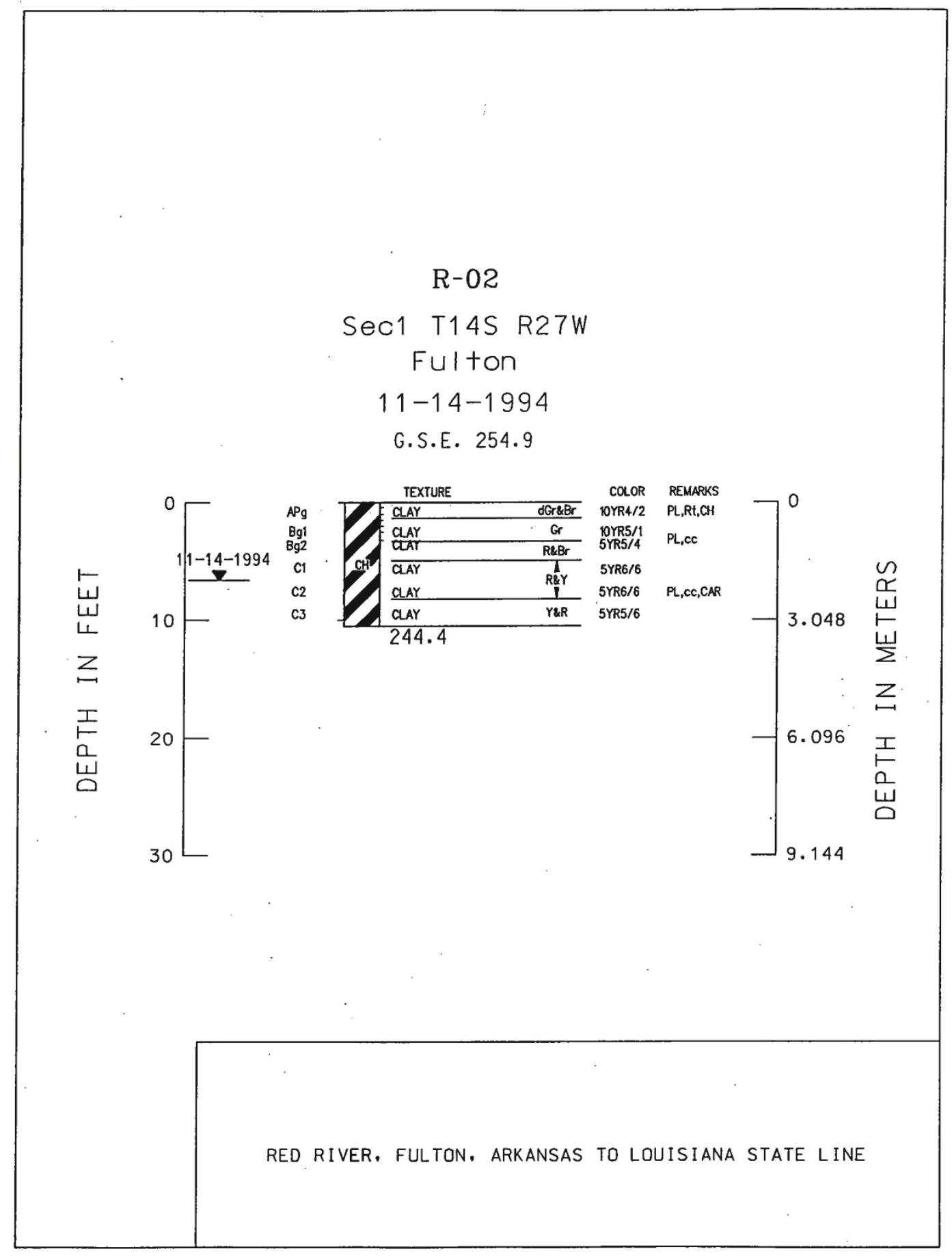




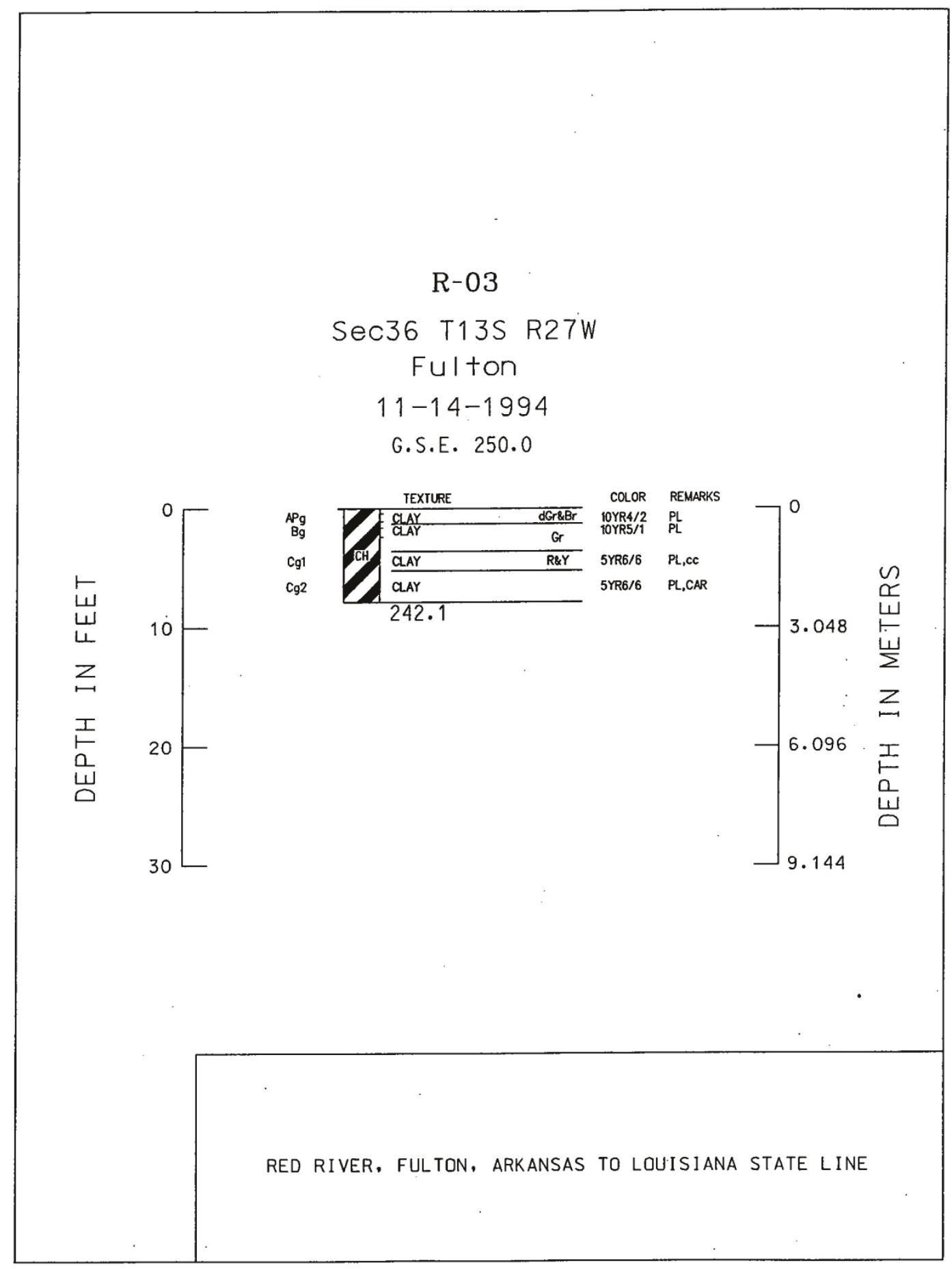




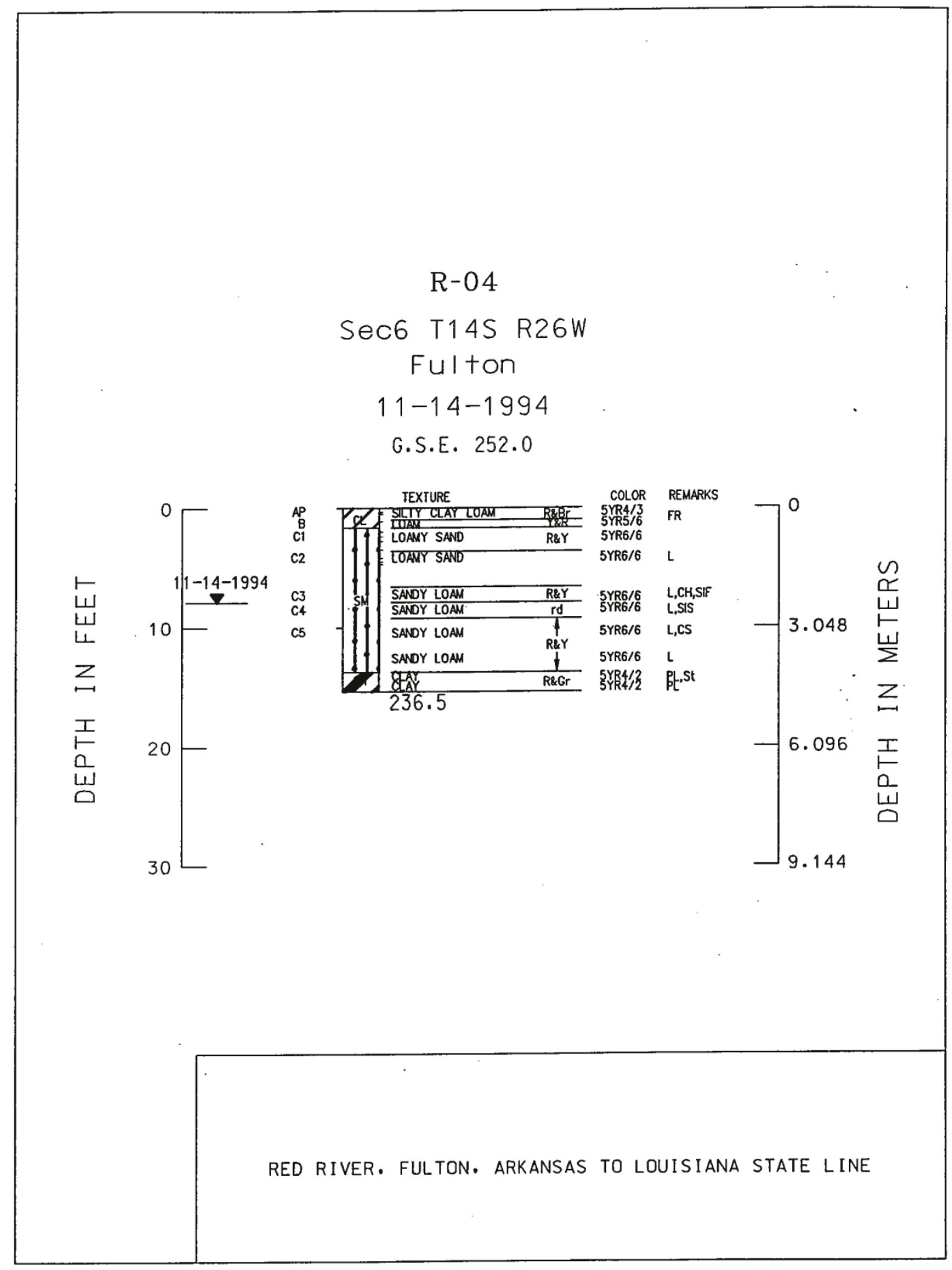




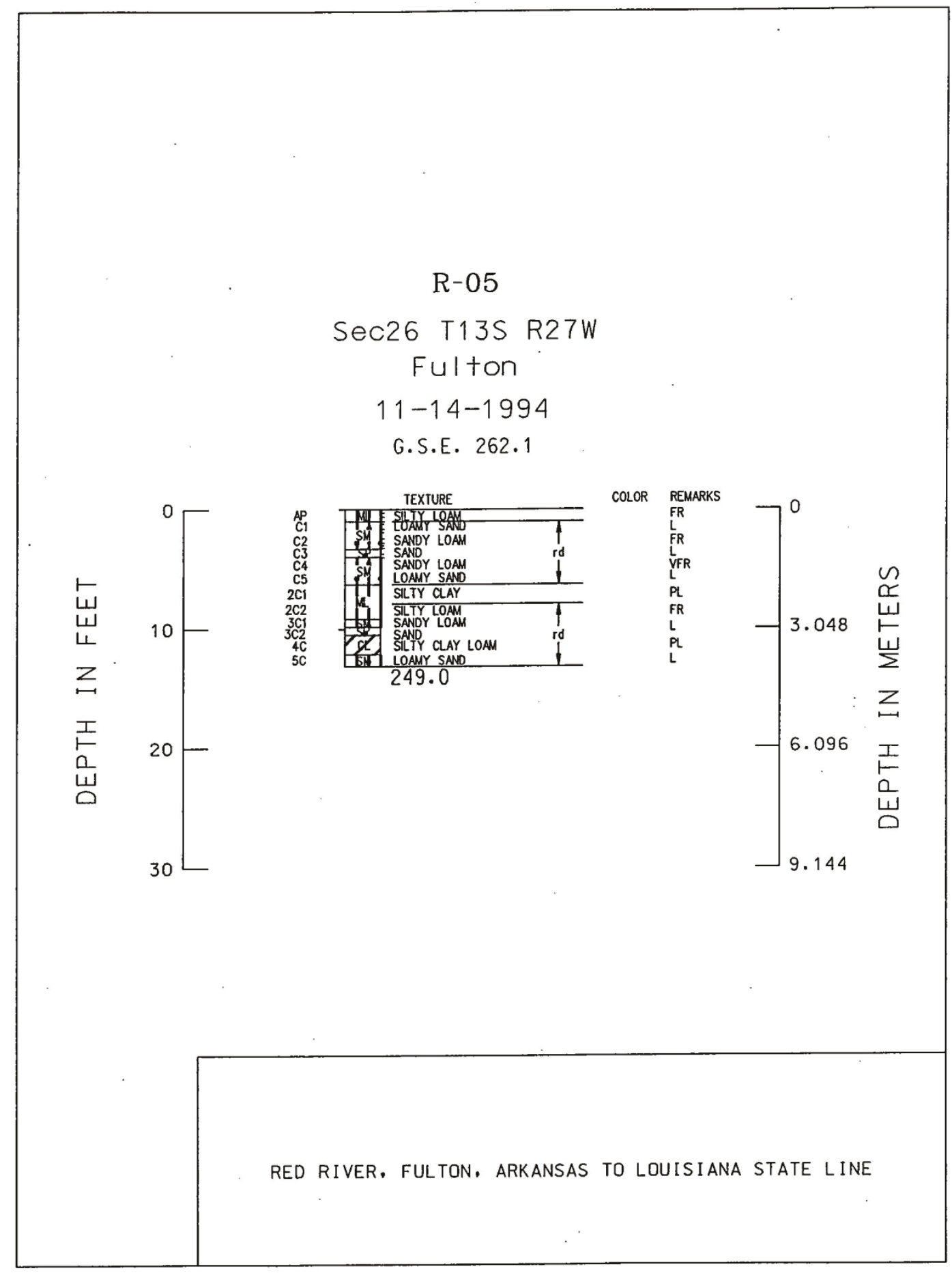




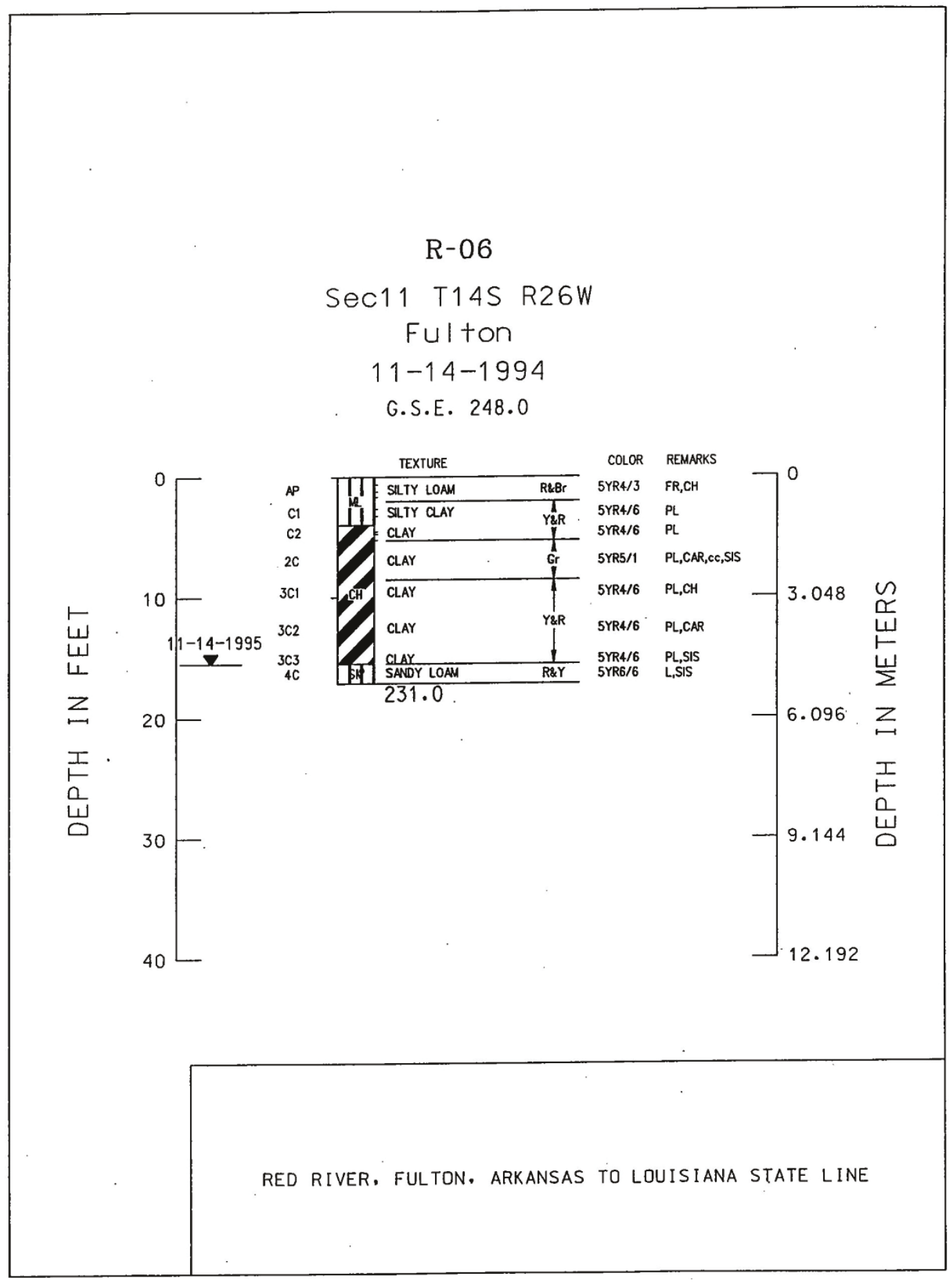




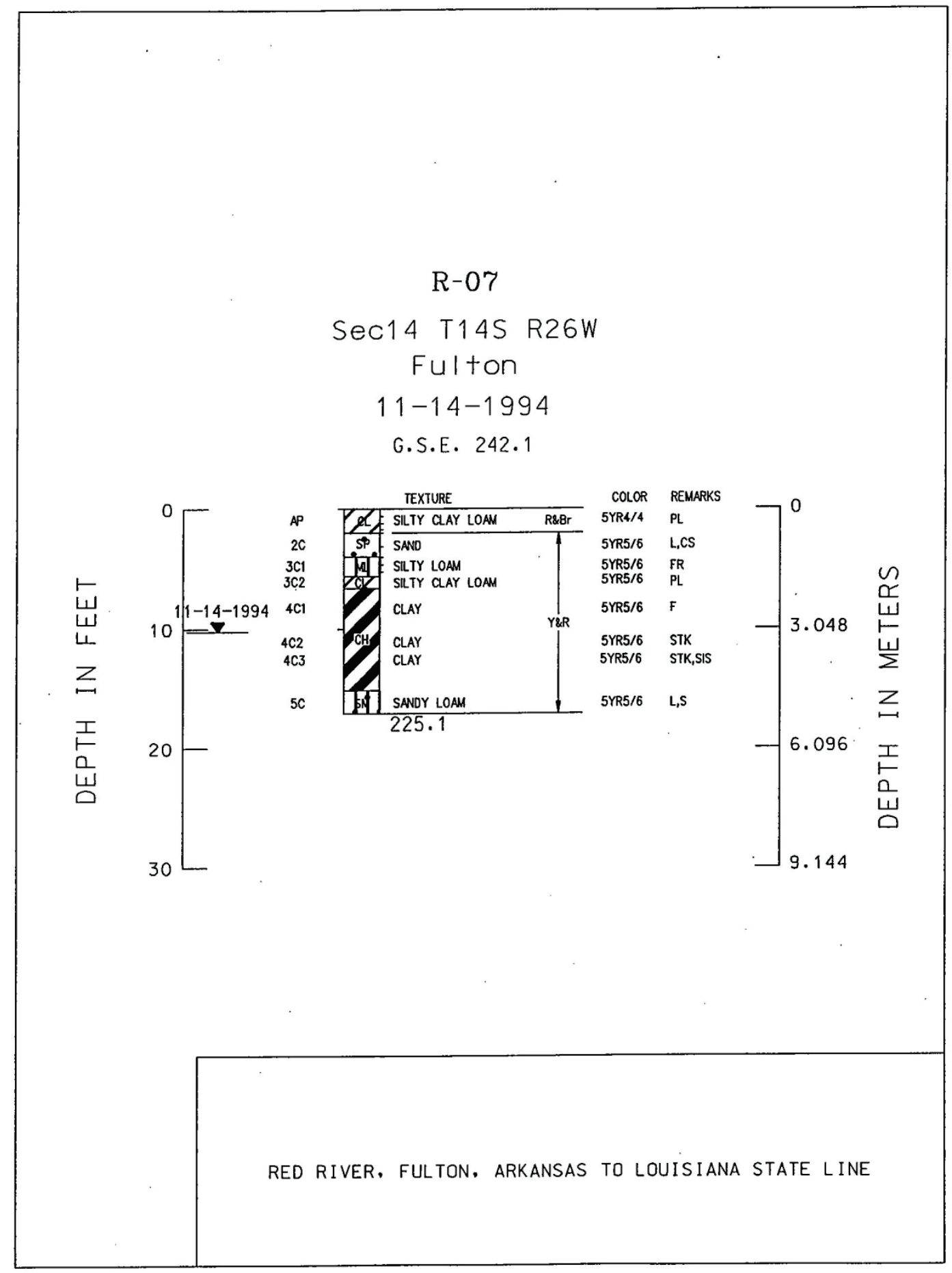




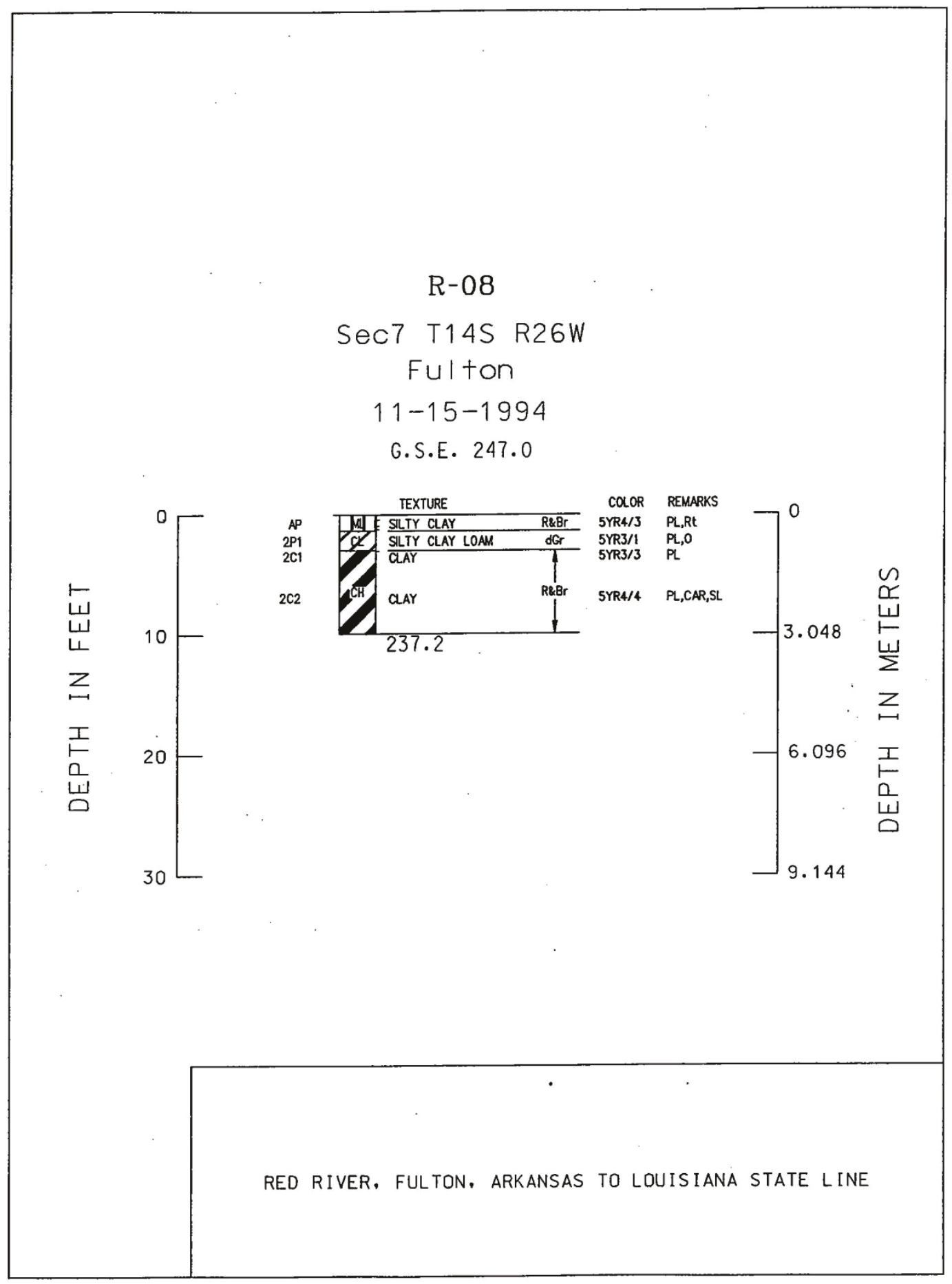




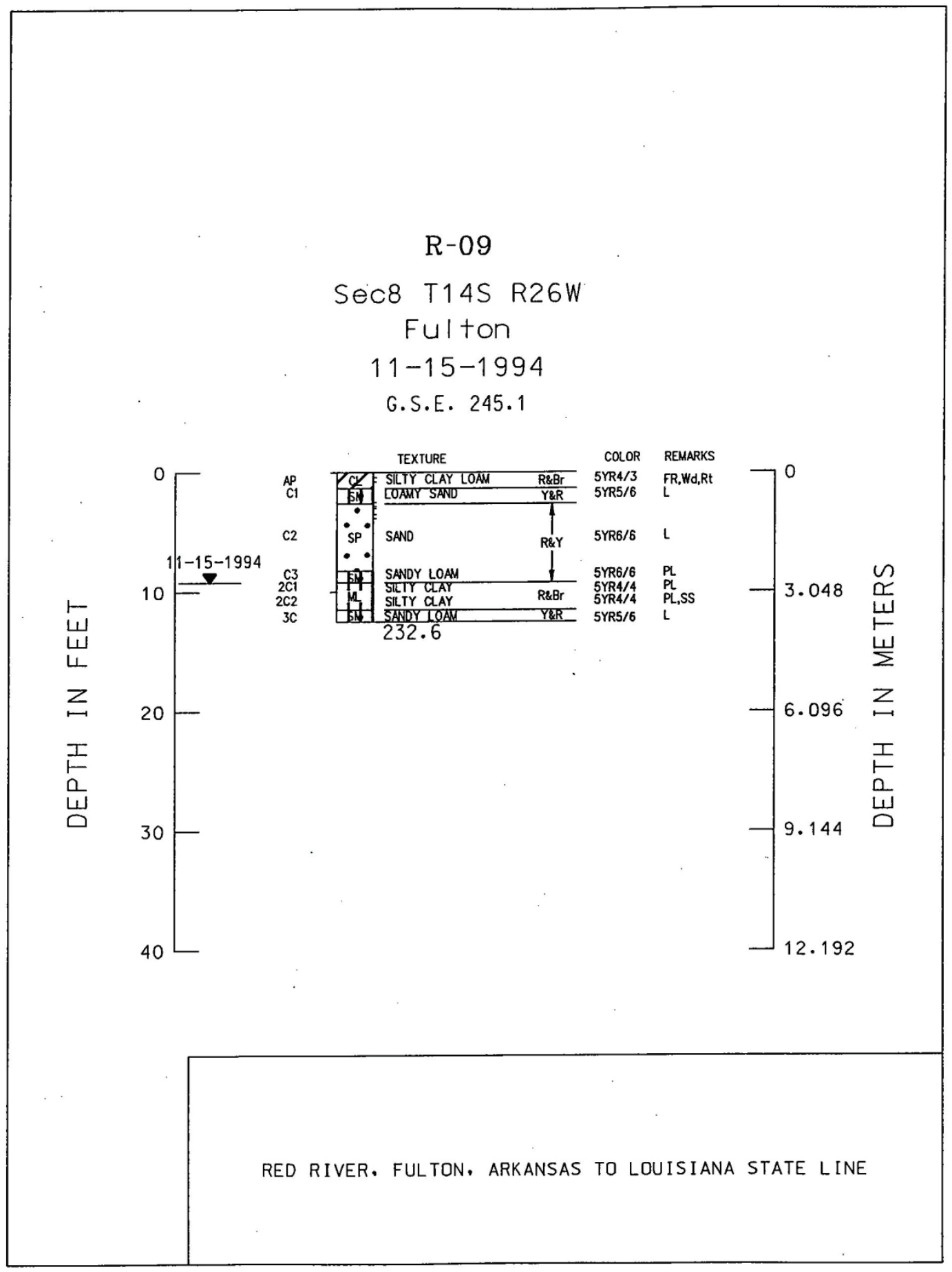




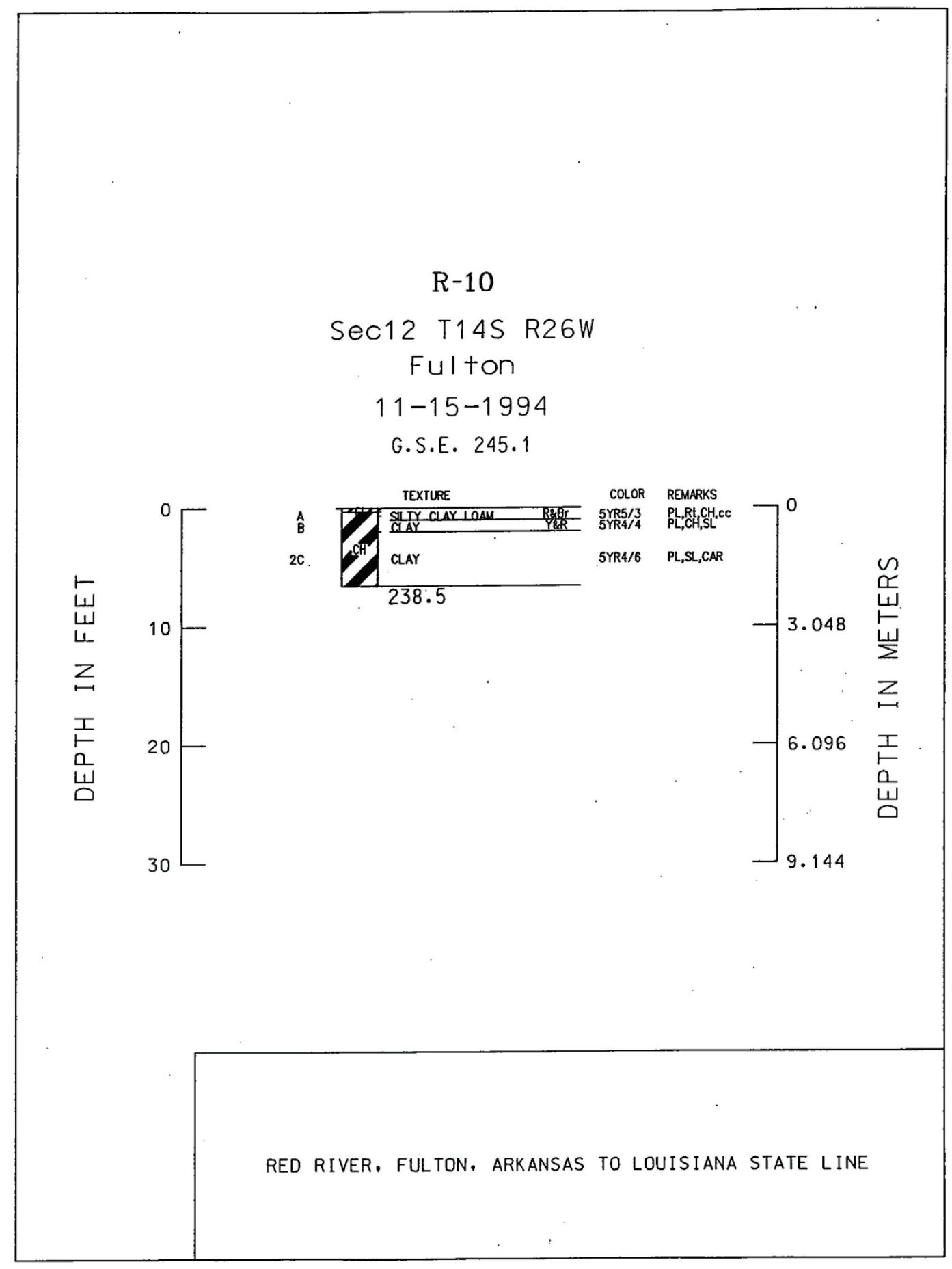




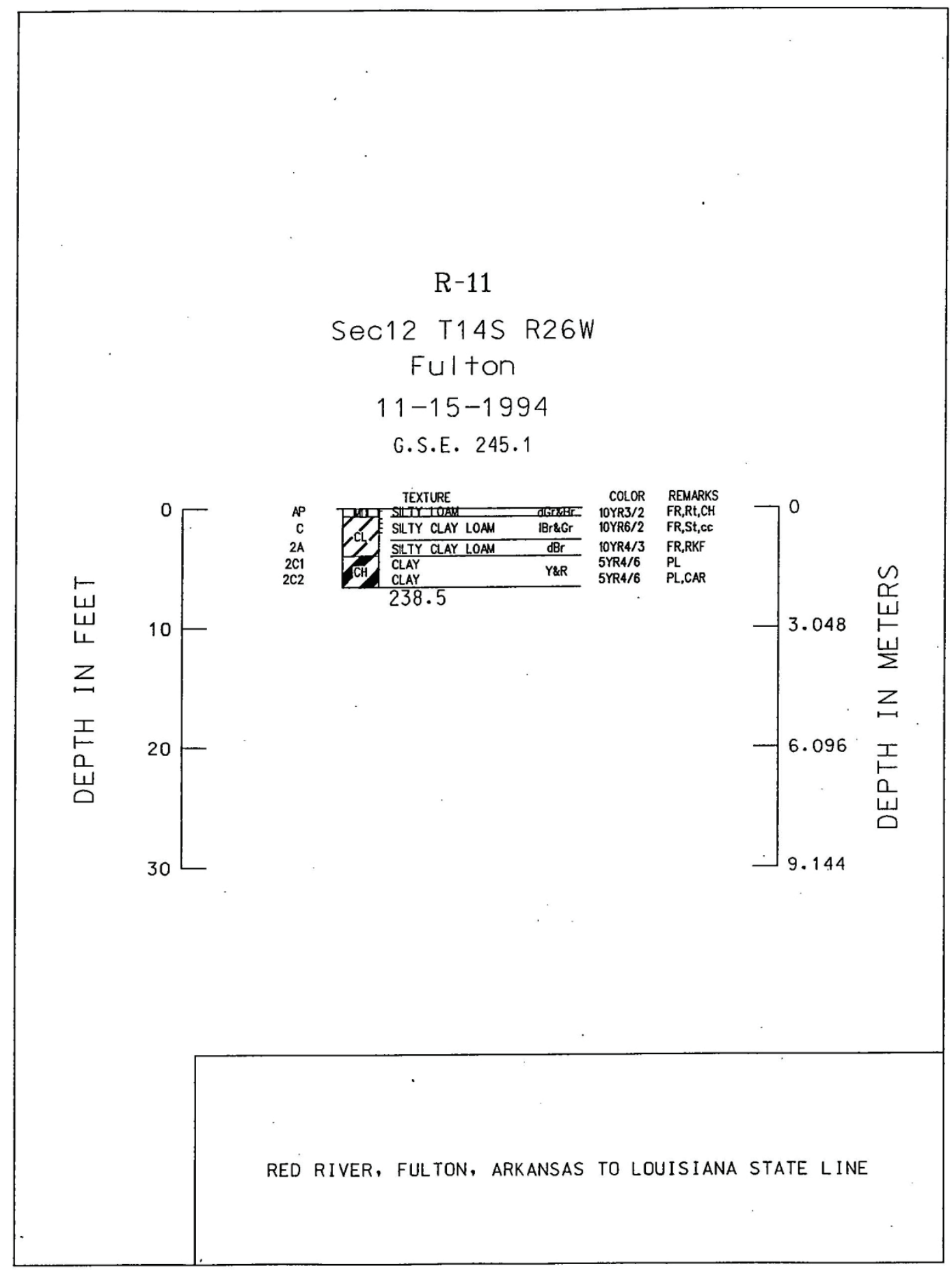




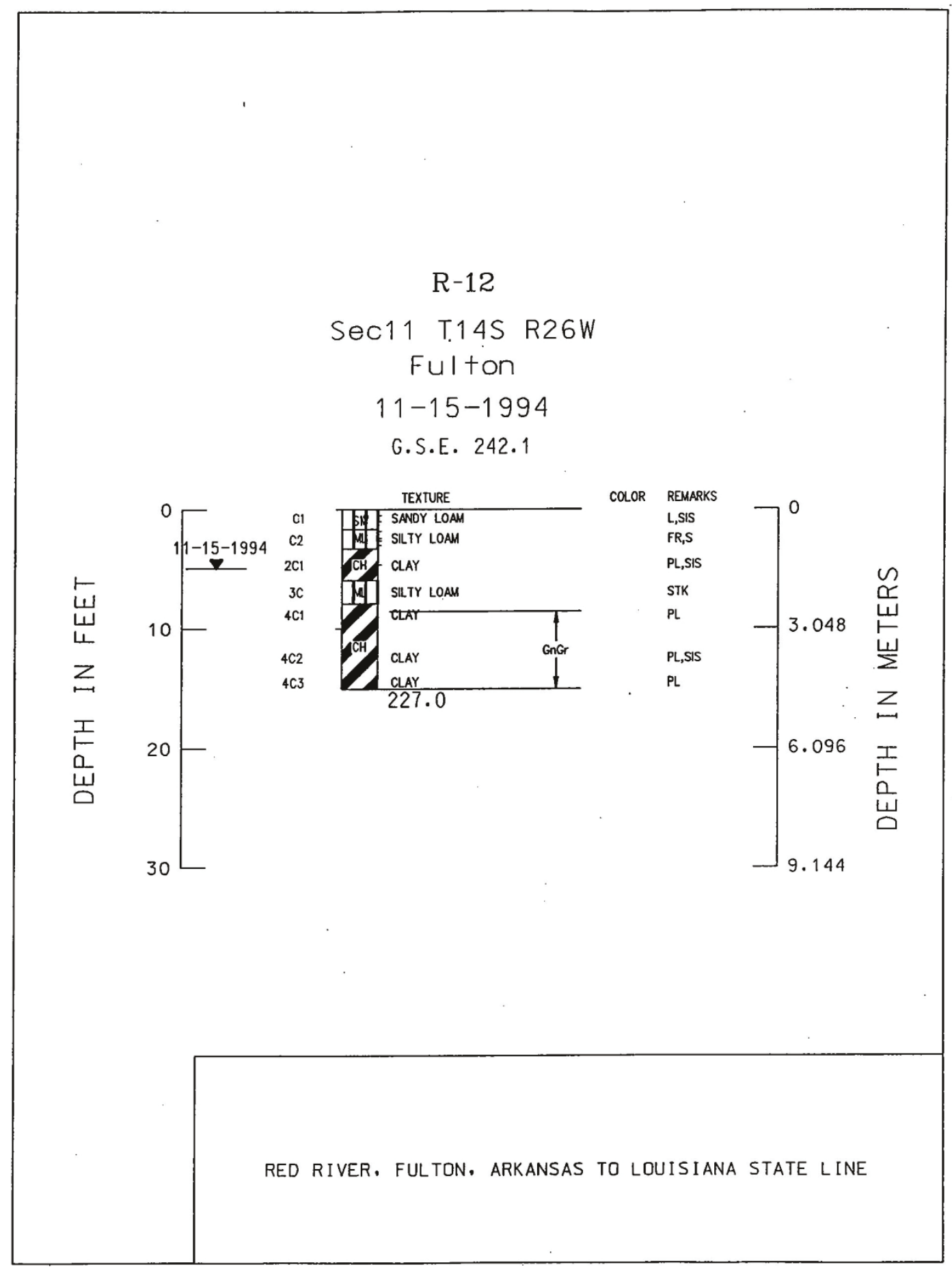




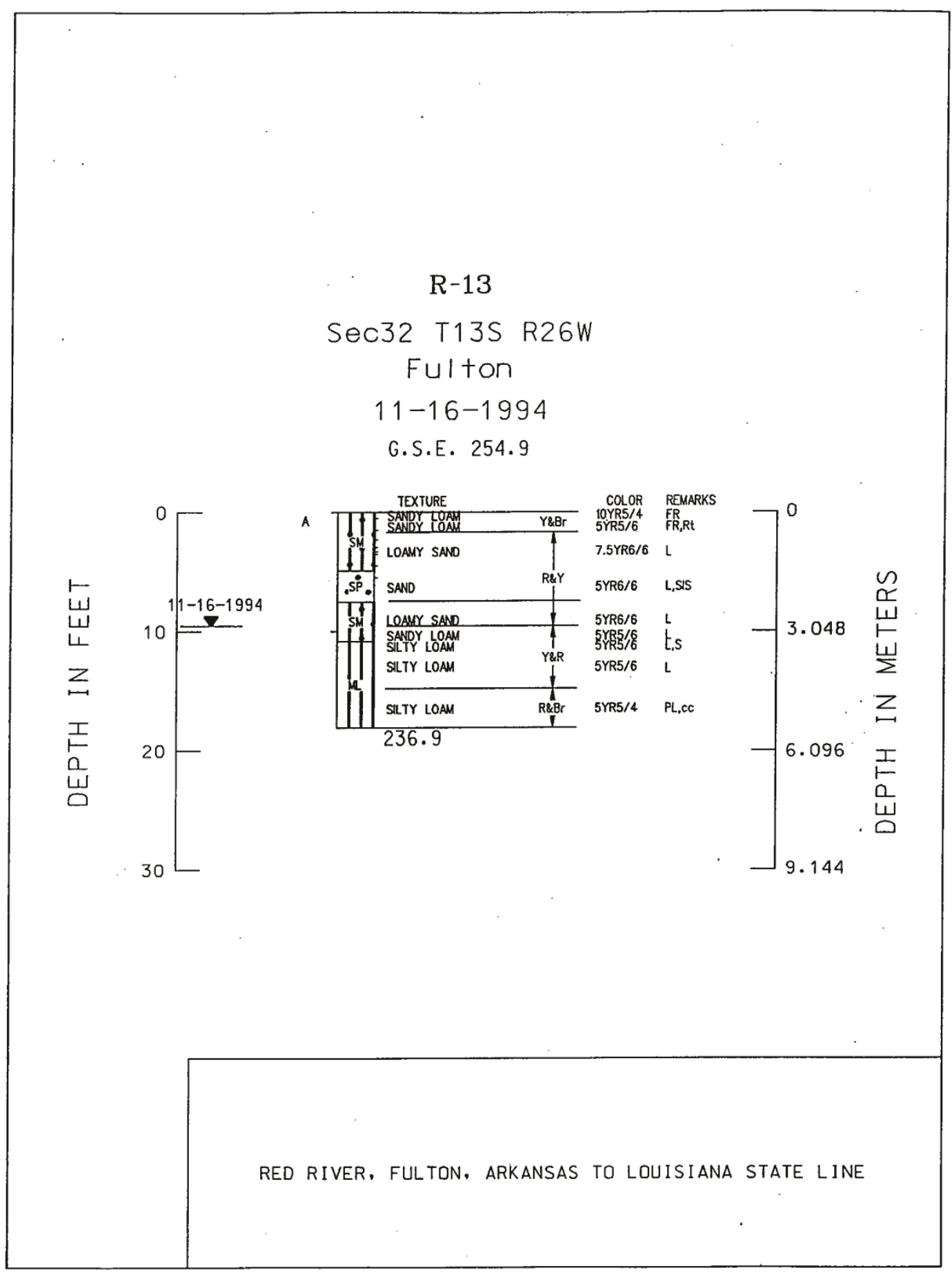




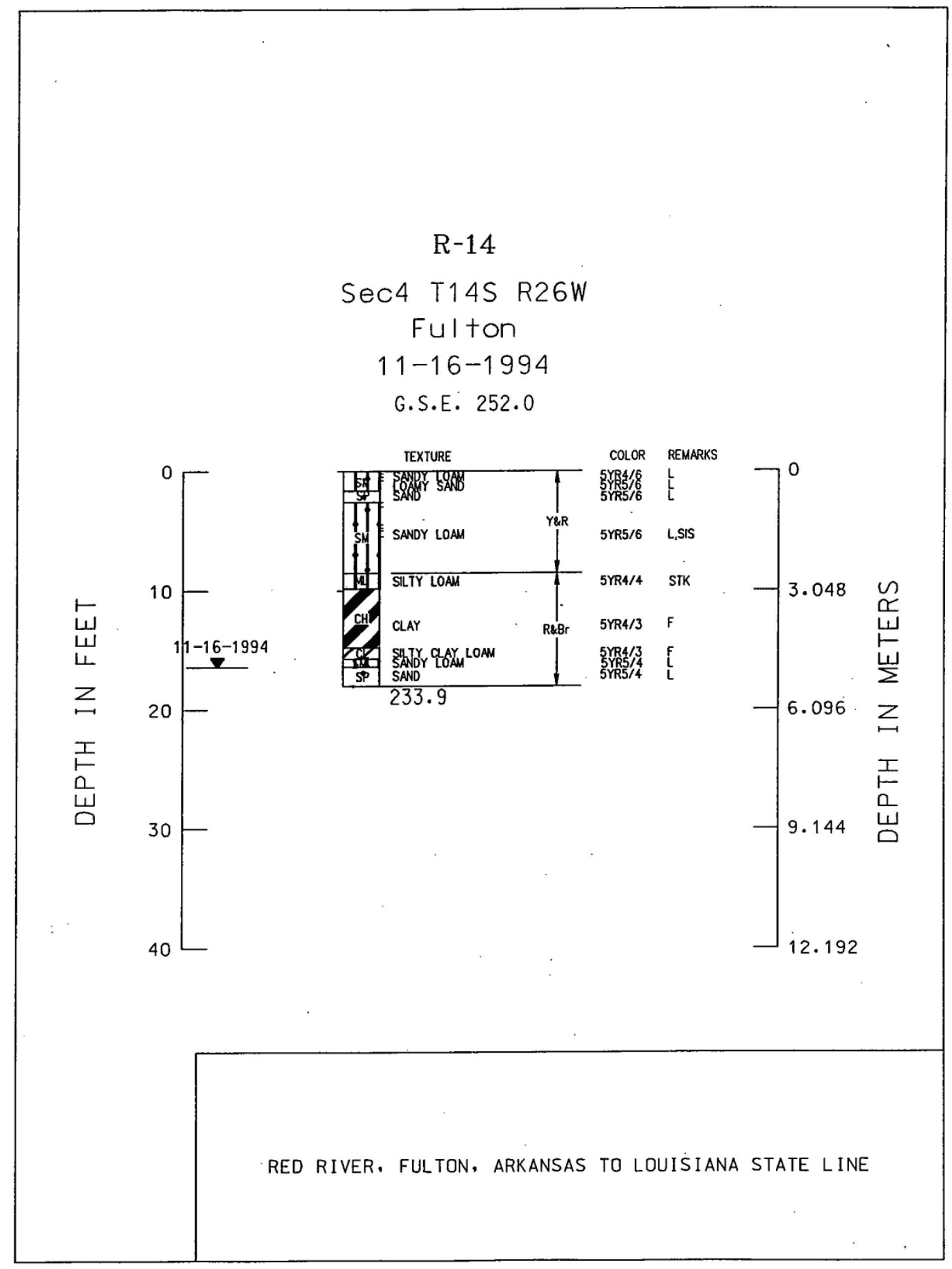




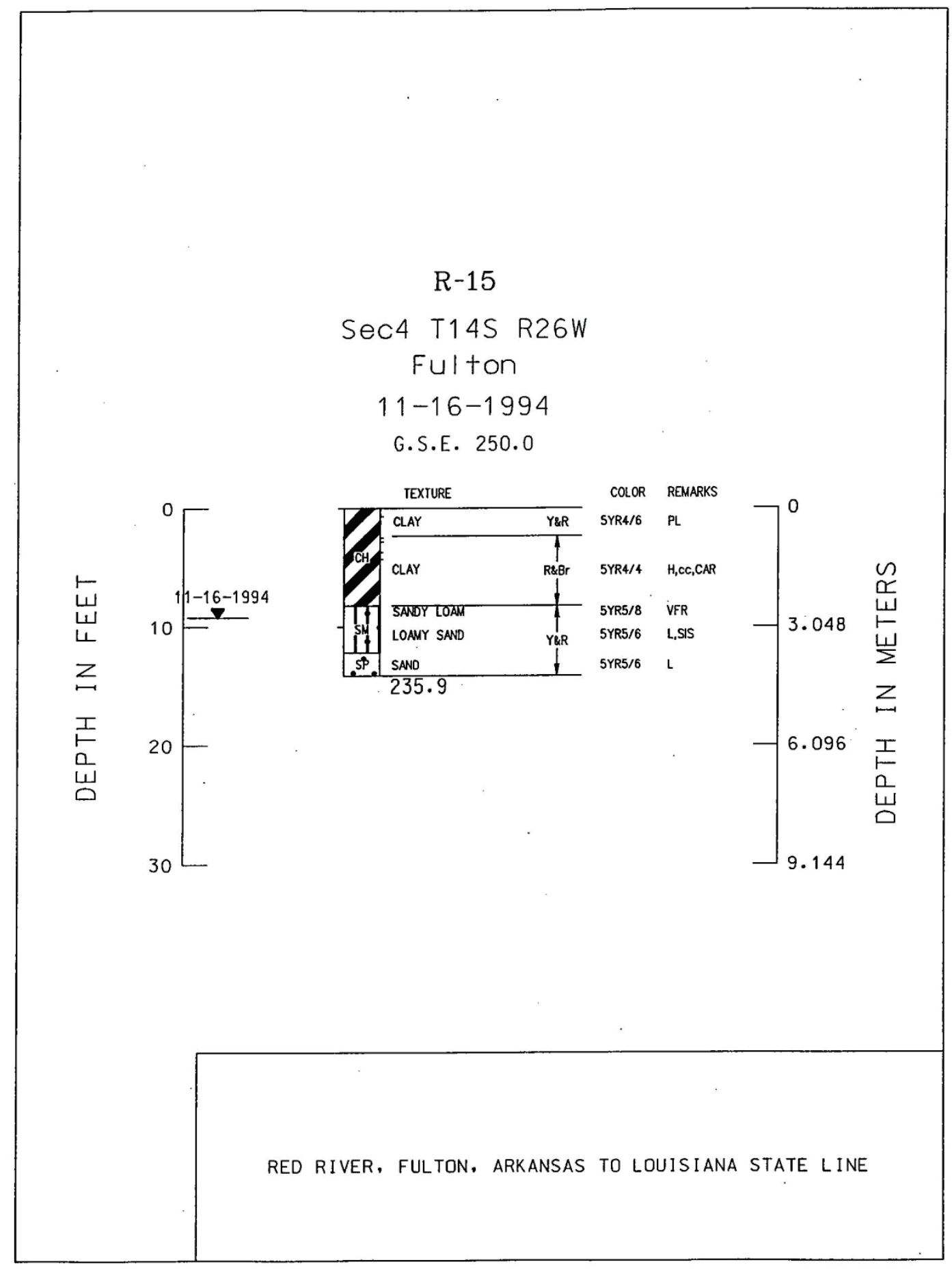




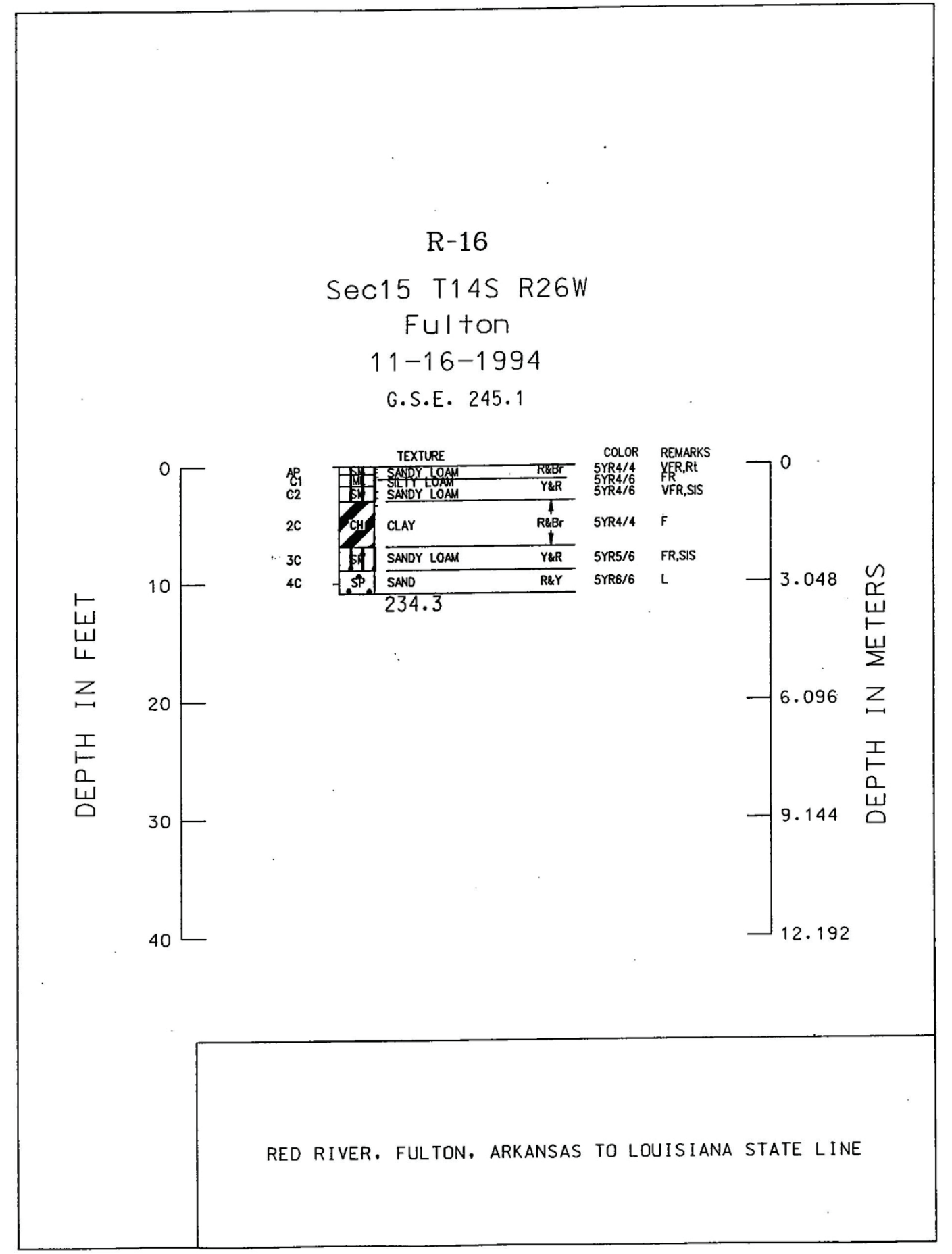




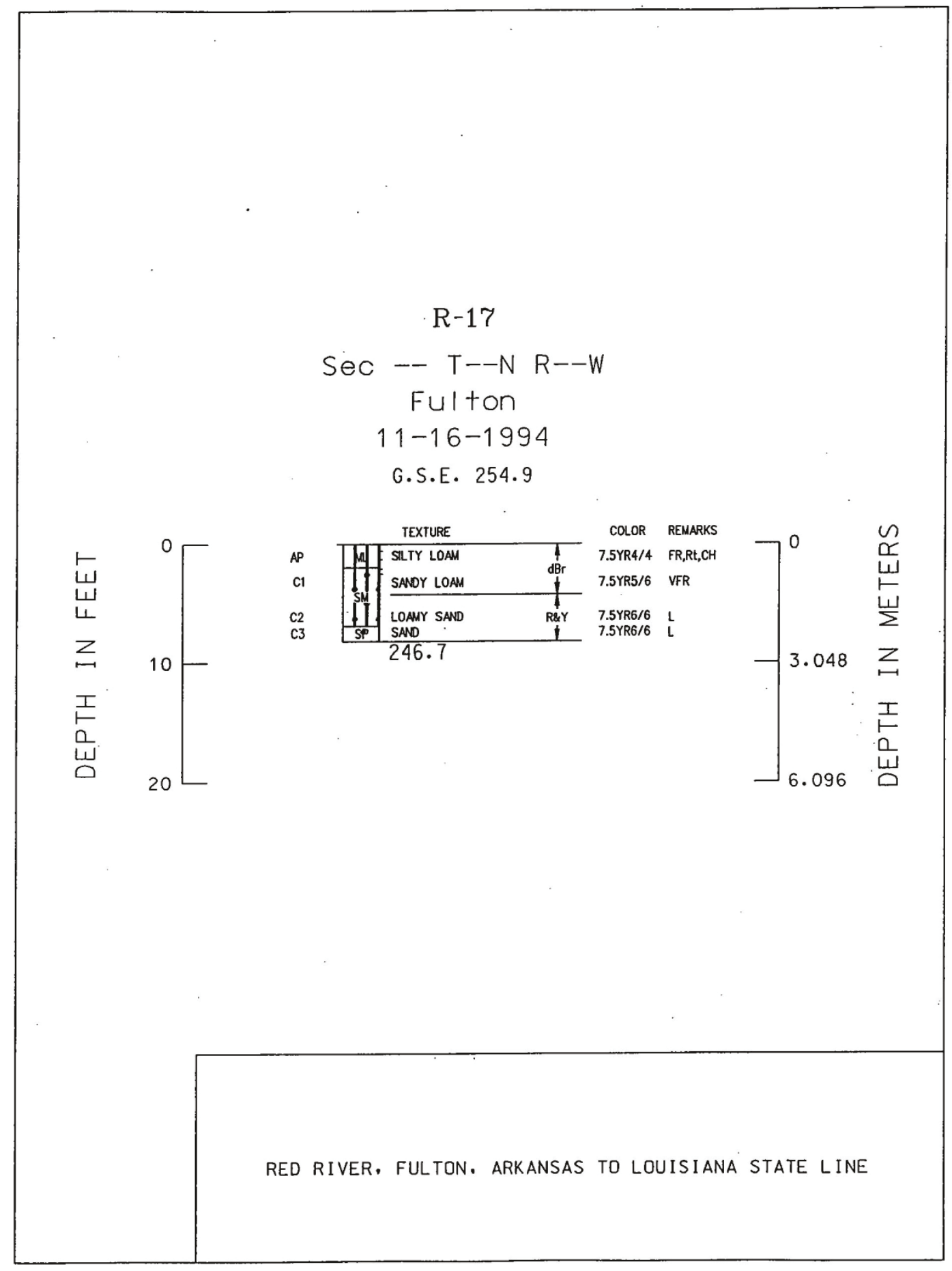




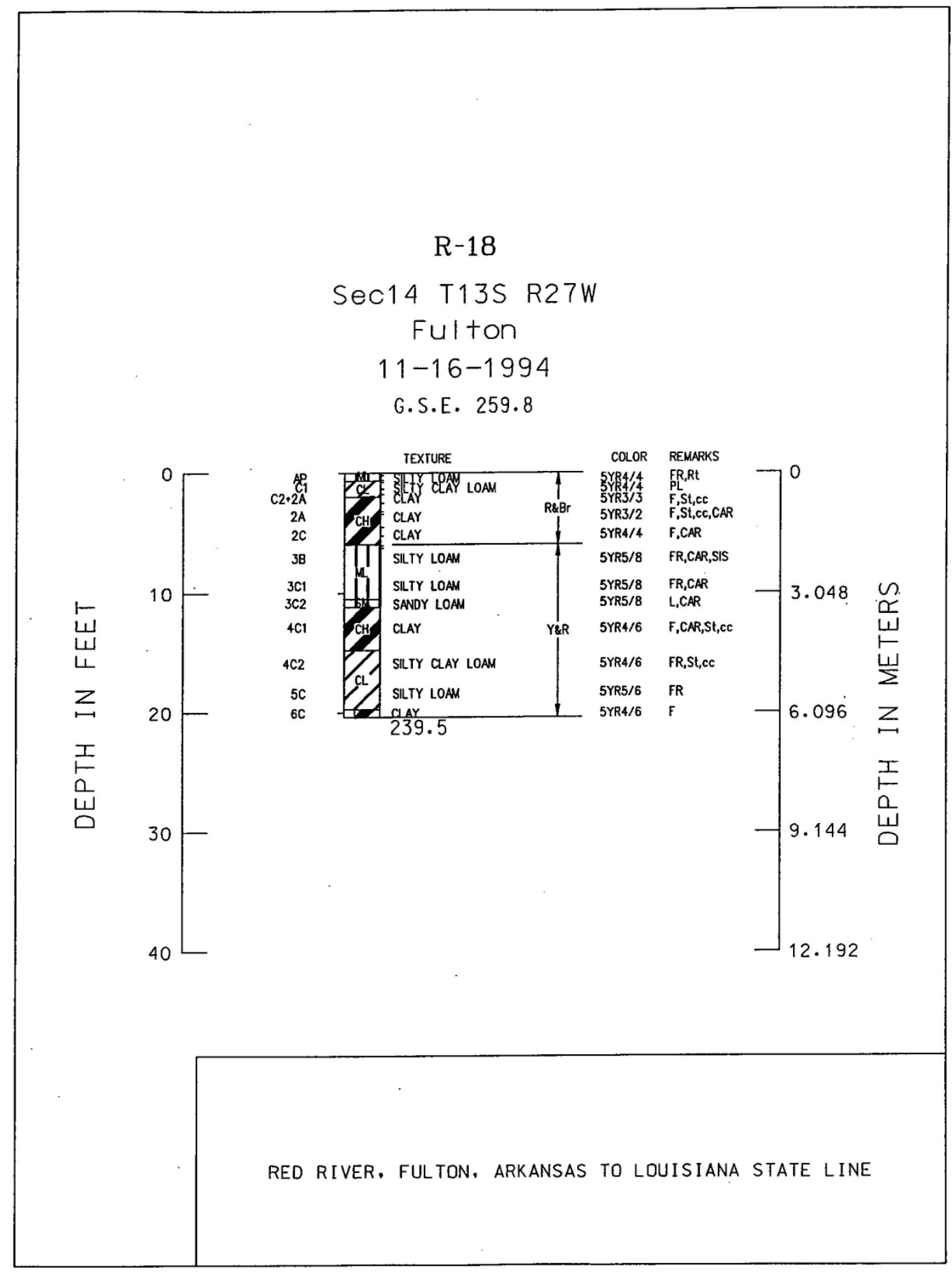




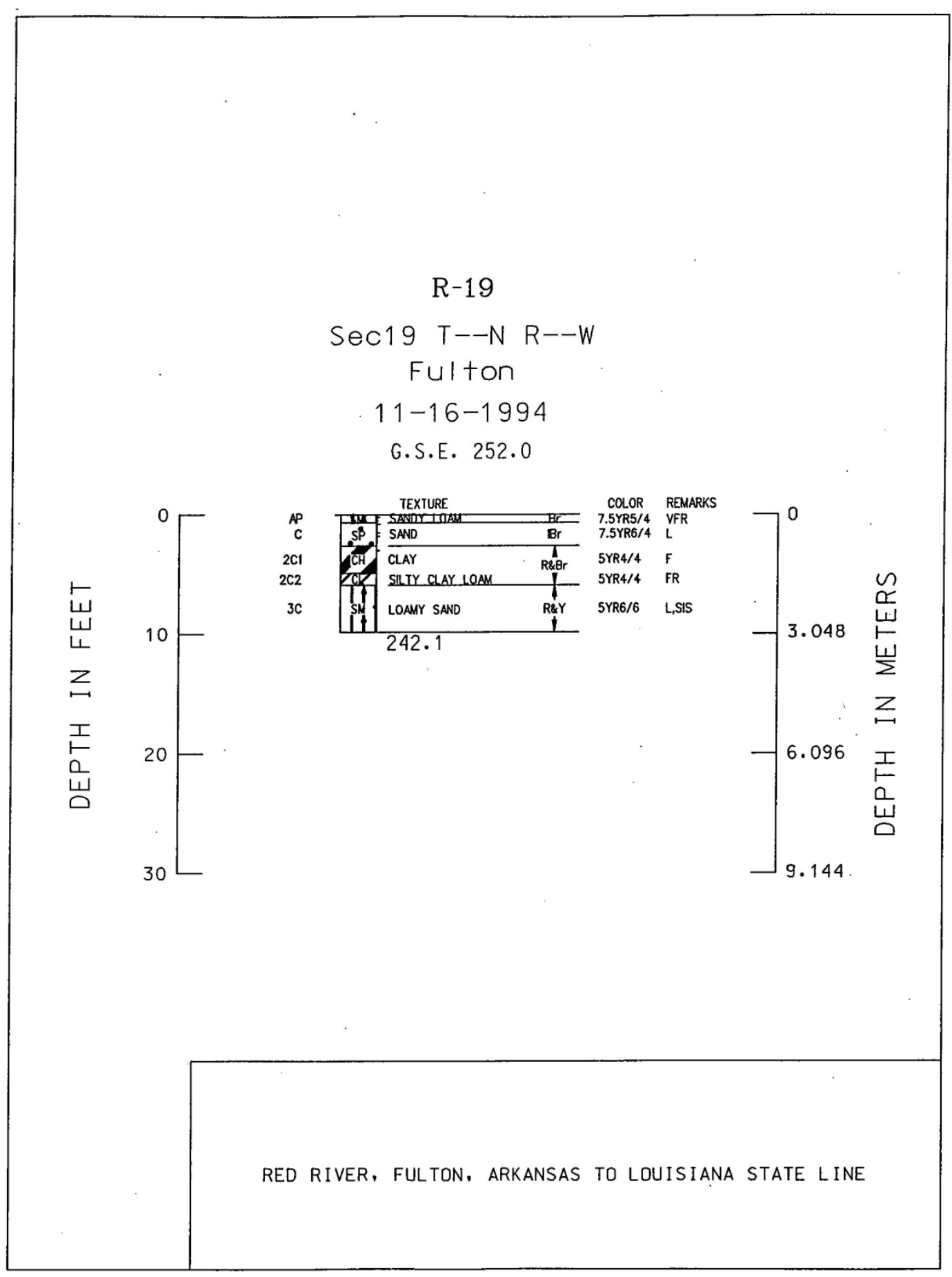




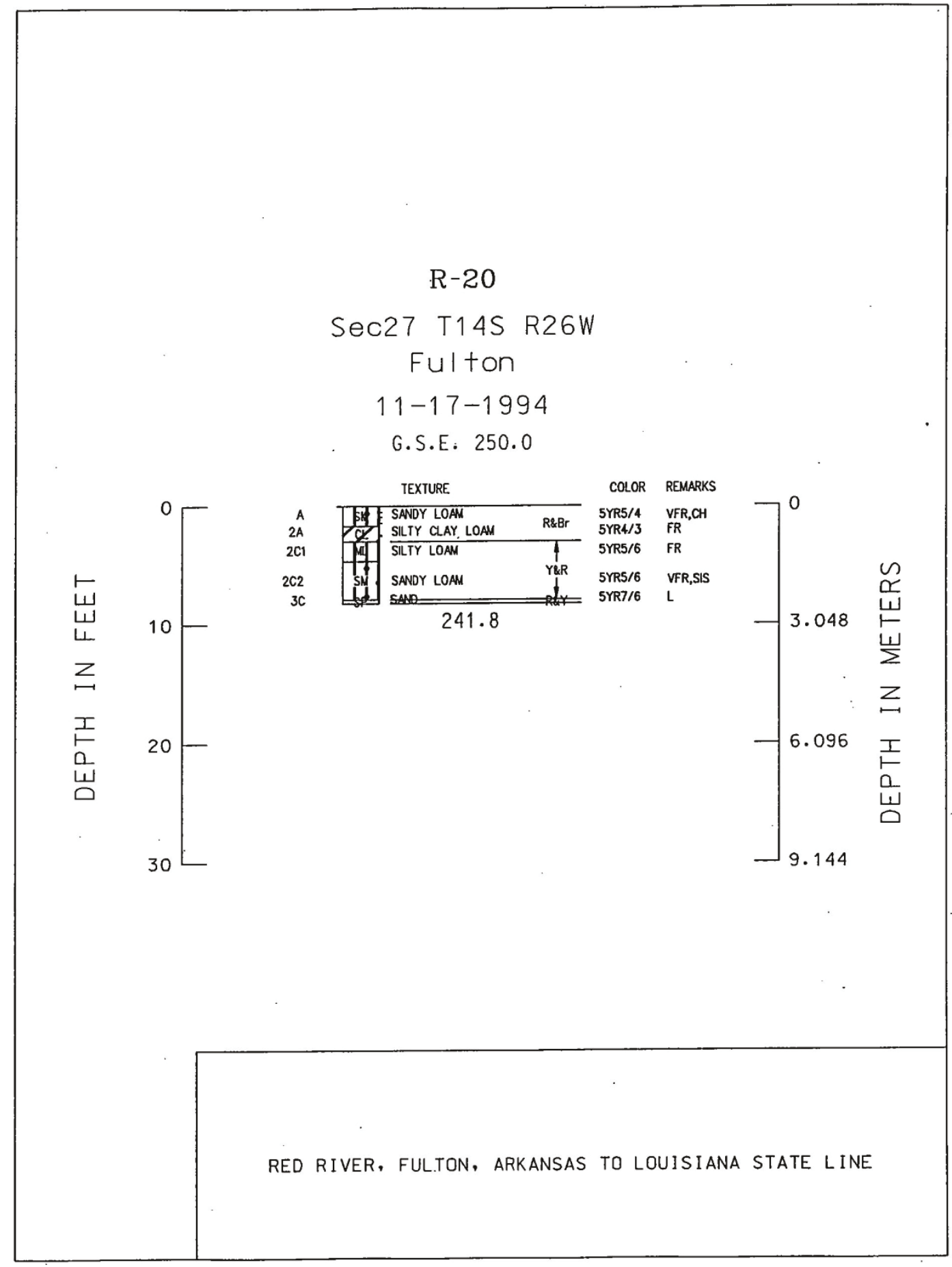




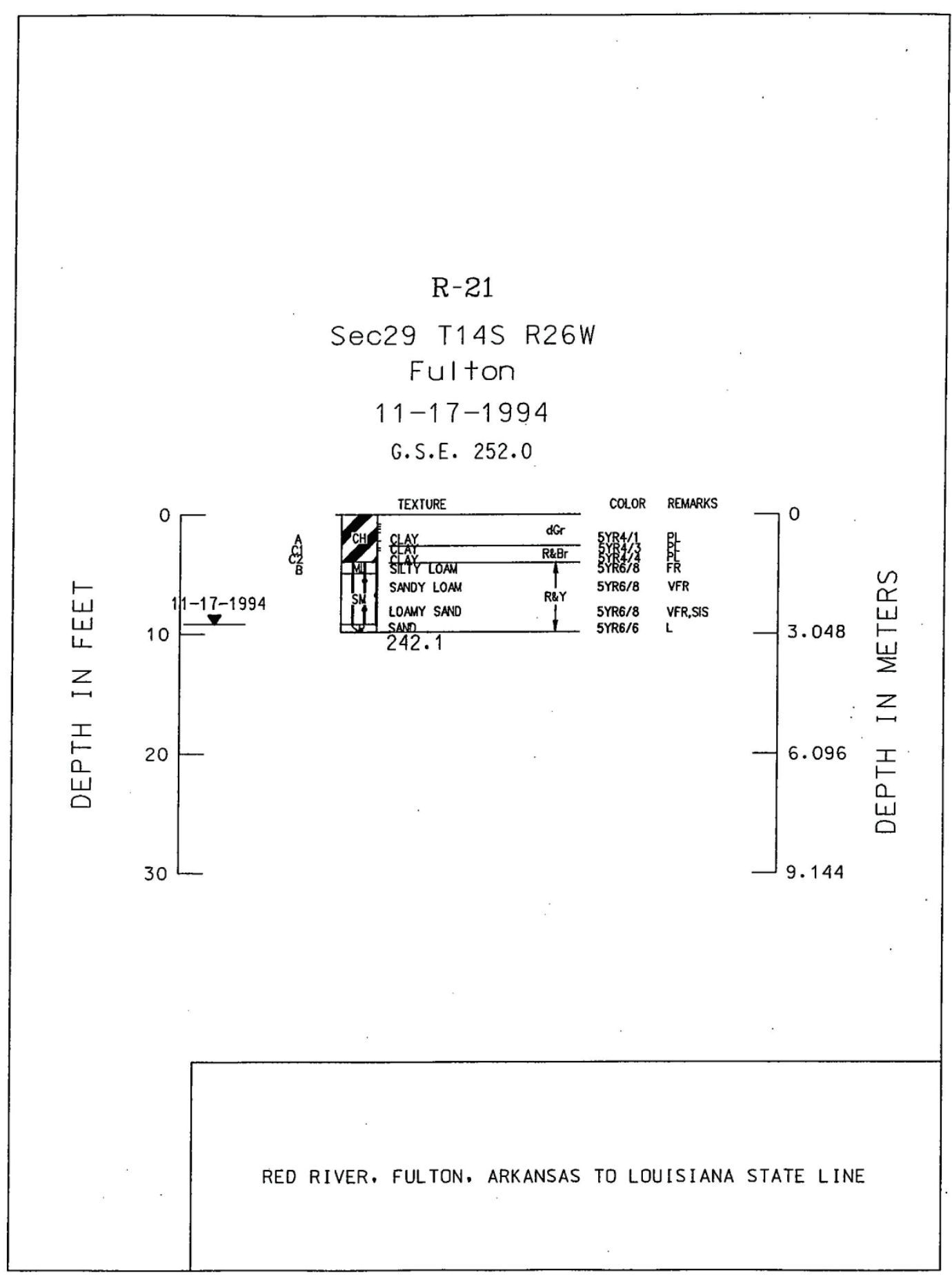




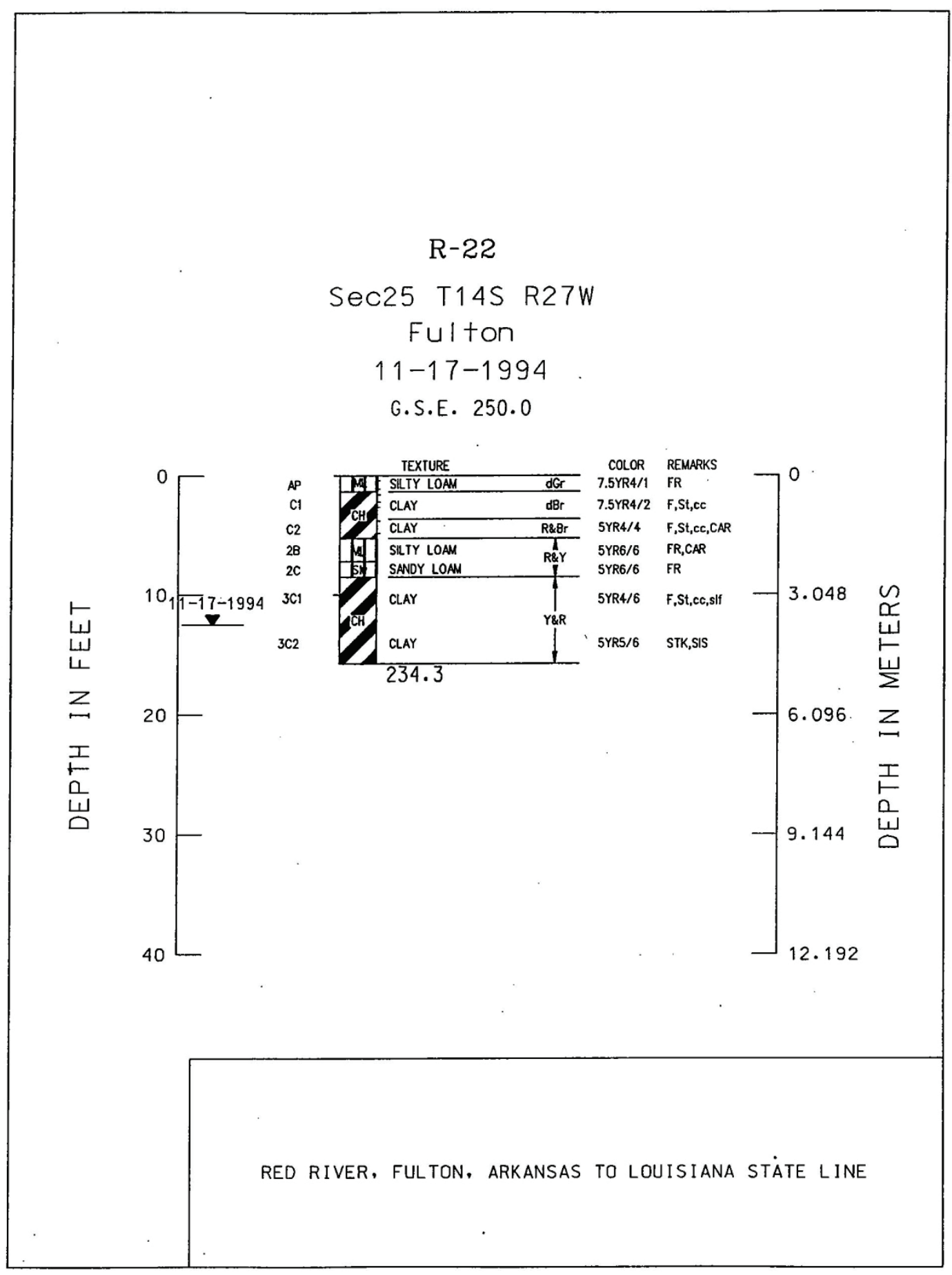




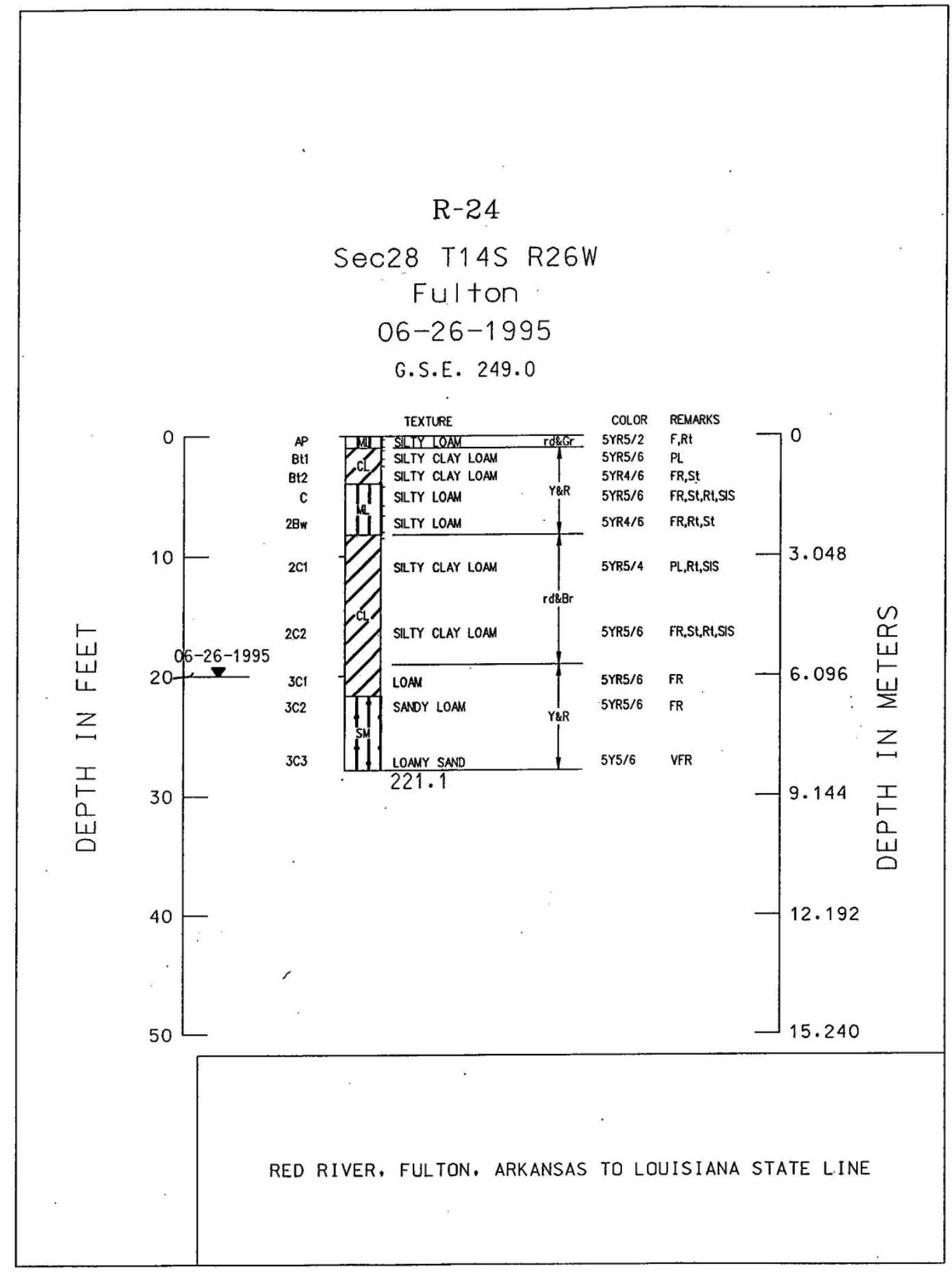




\section{$\mathrm{R}-25$ \\ Sec2 T14S R26W}

Fouke NE

06-26-1995

G.S.E. 245.1

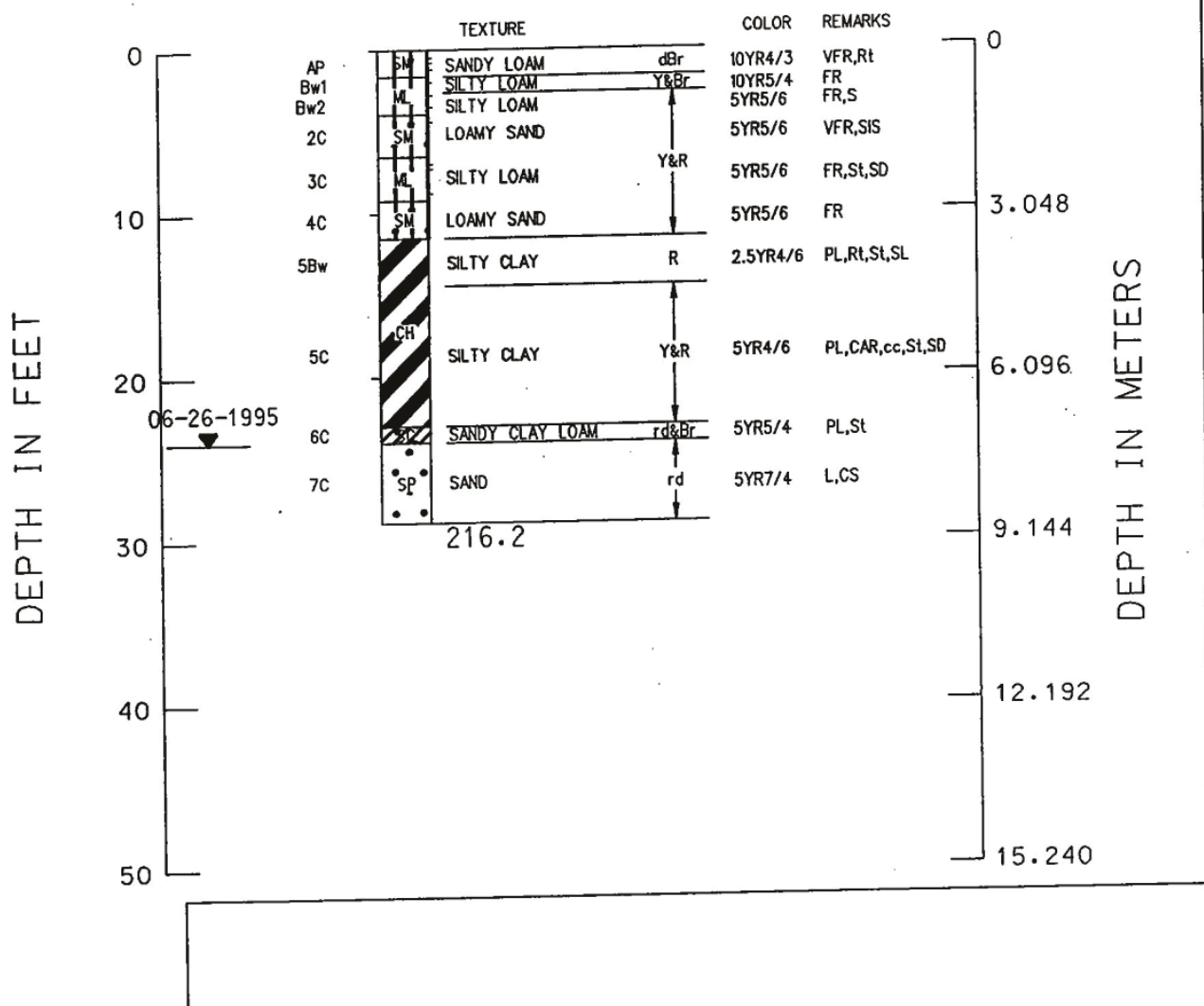

RED RIVER, FULTON. ARKANSAS TO LOUISIANA STATE LINE 


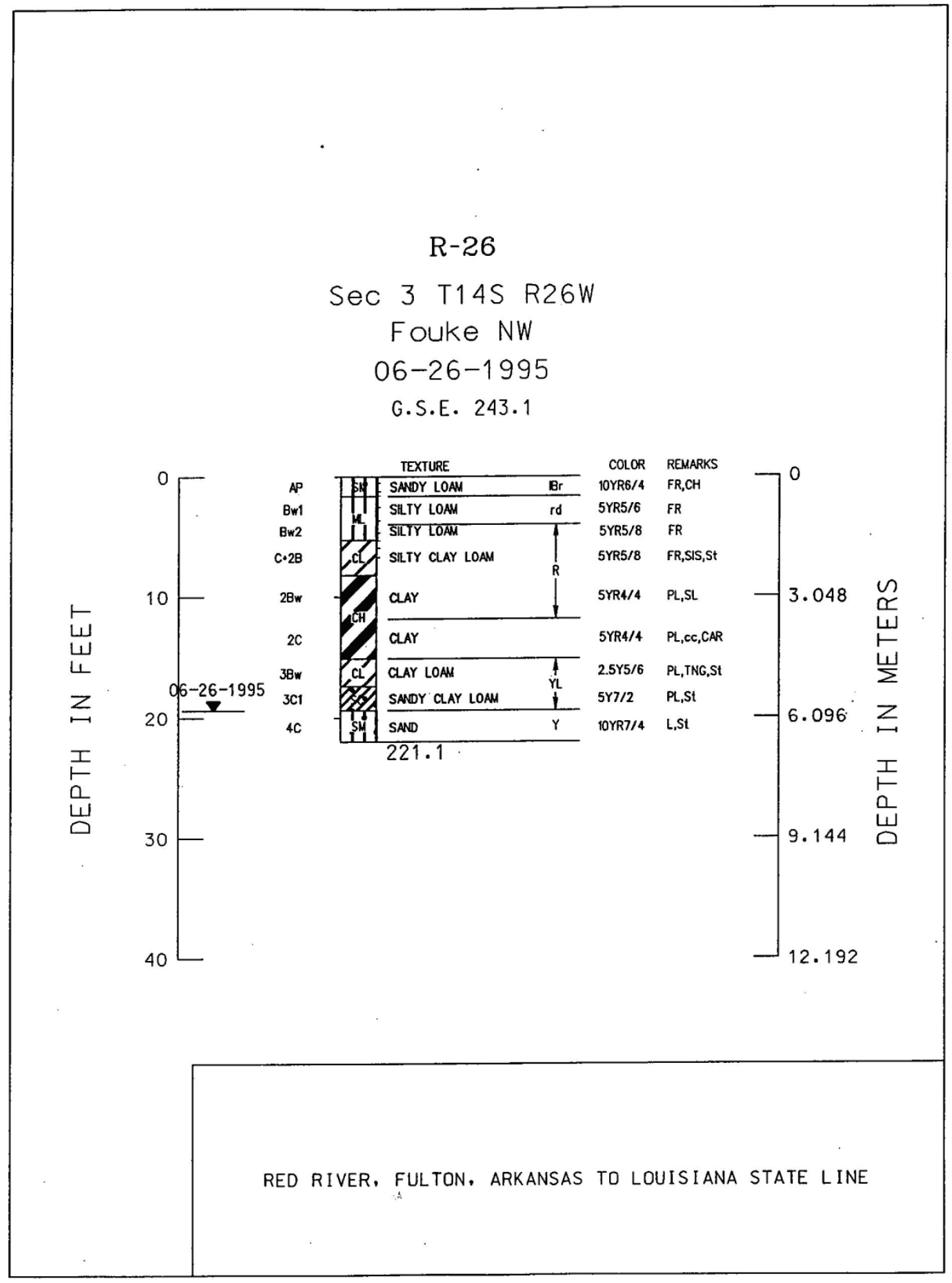




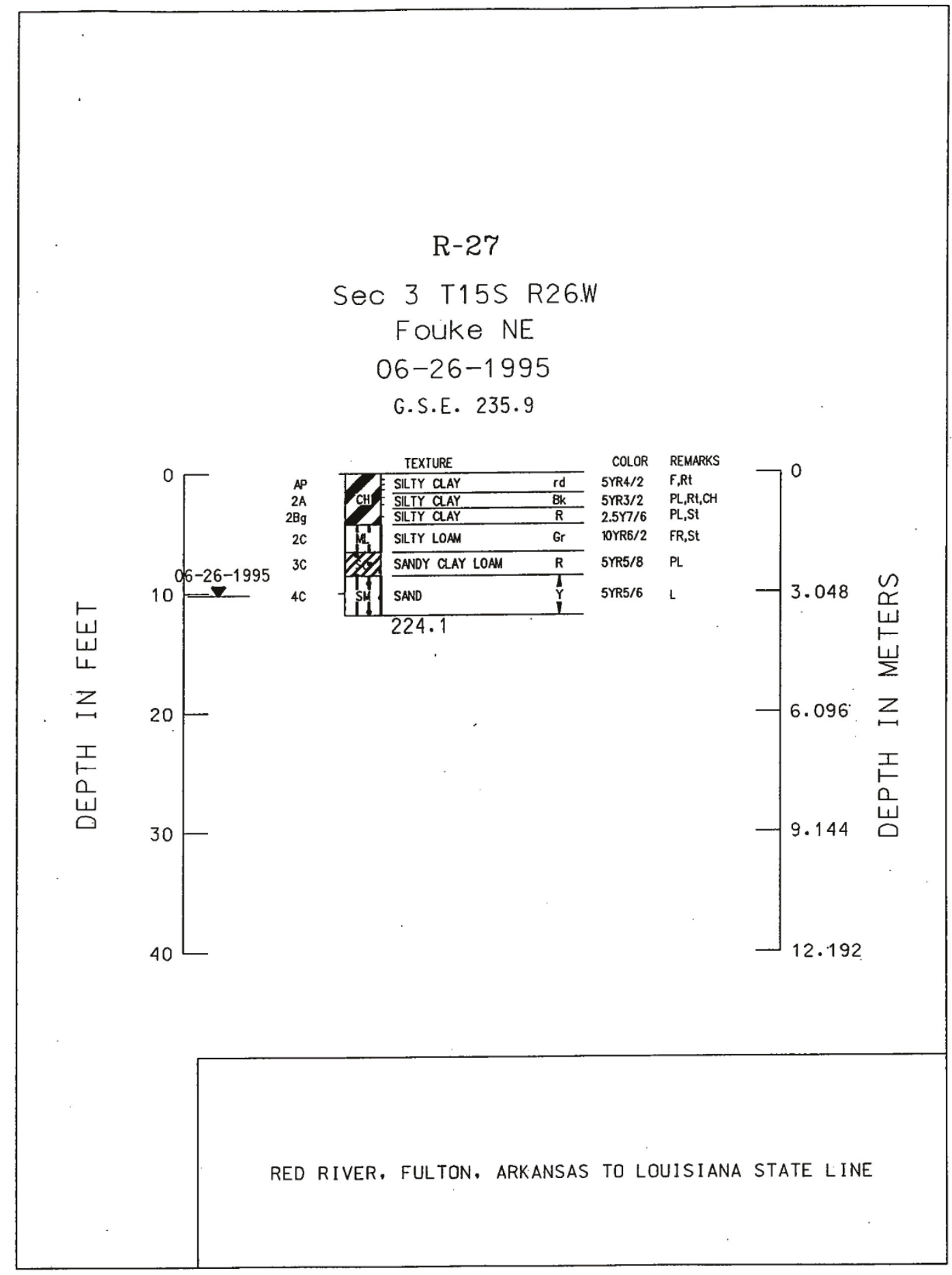




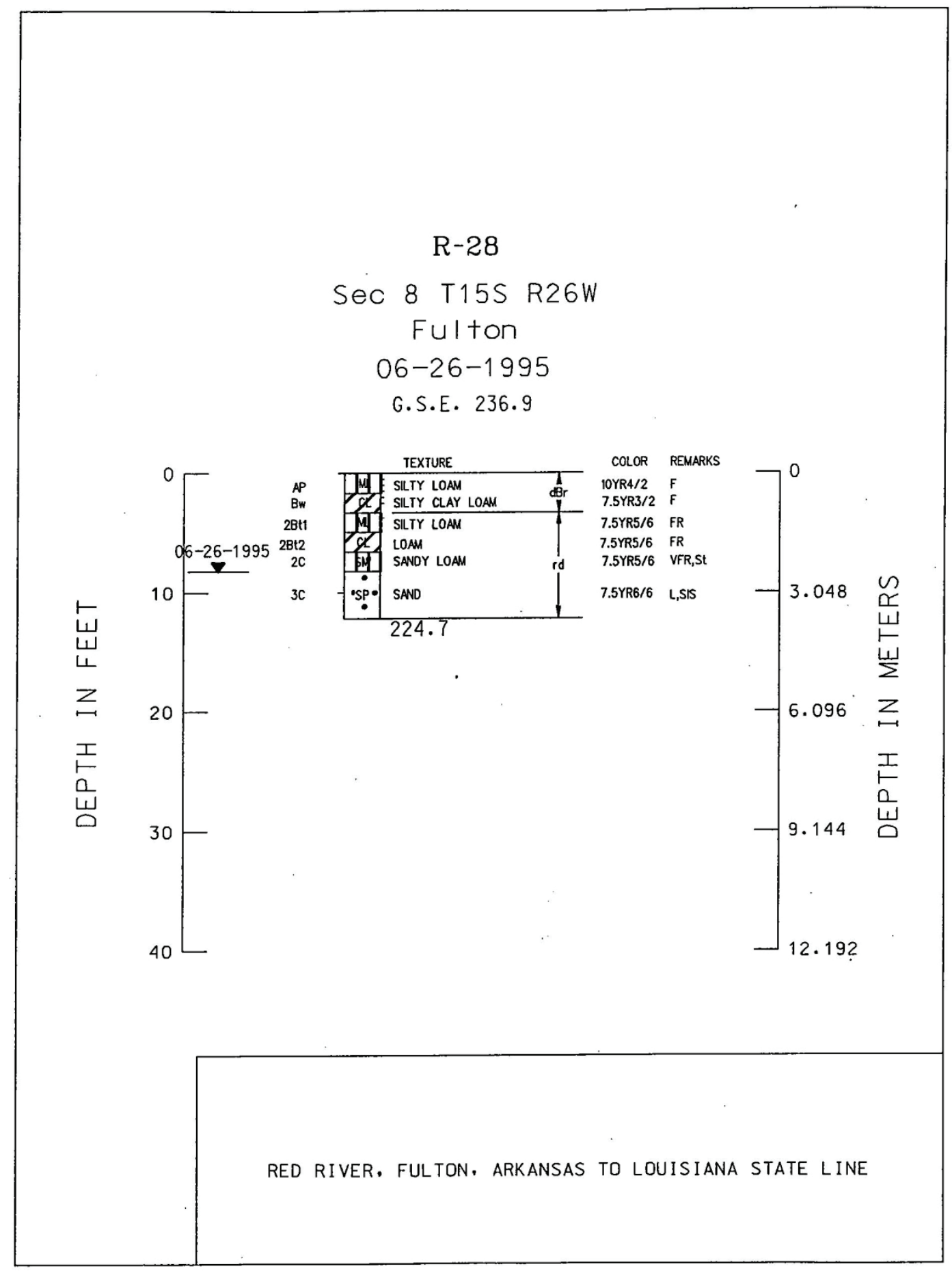




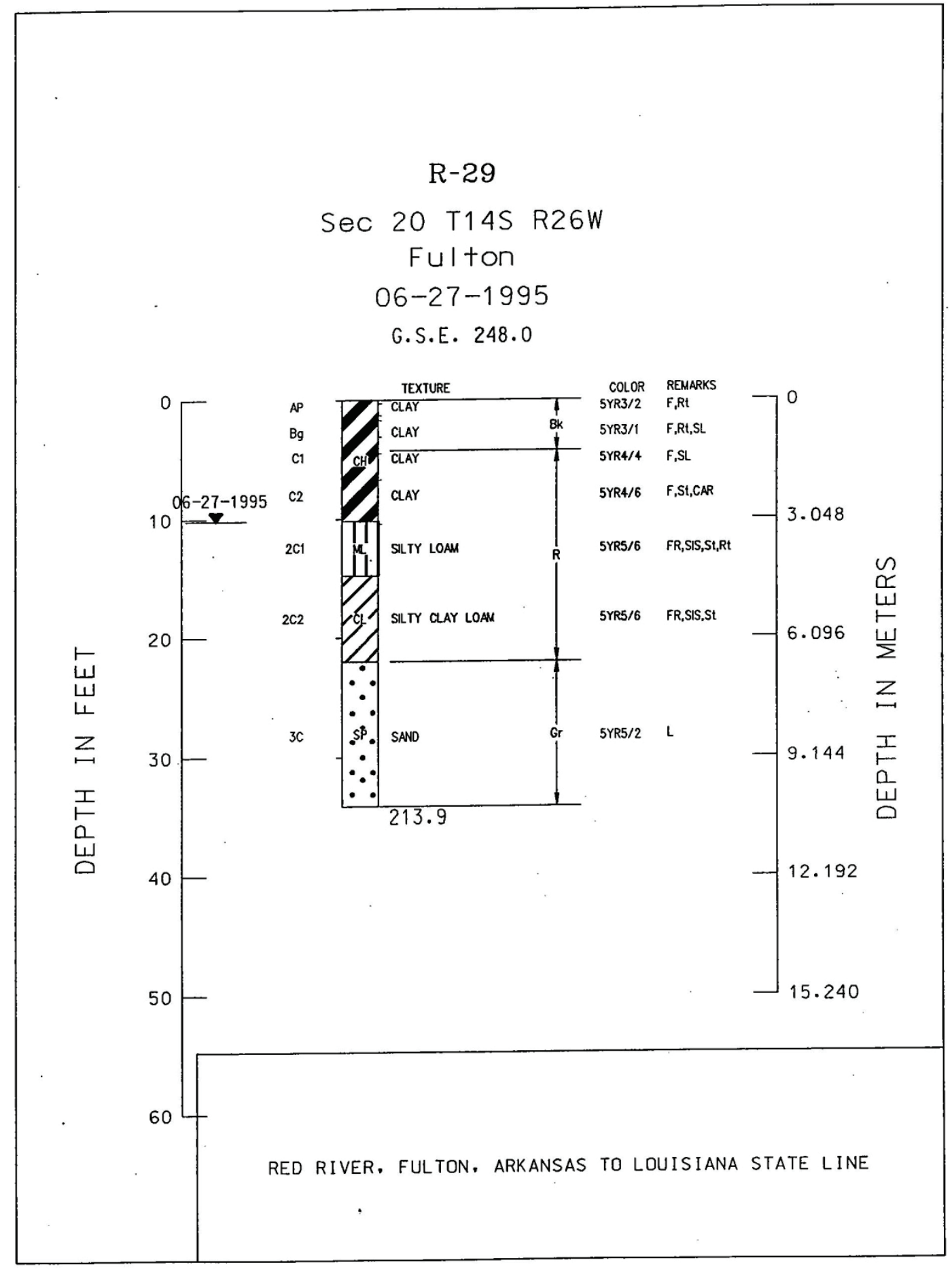




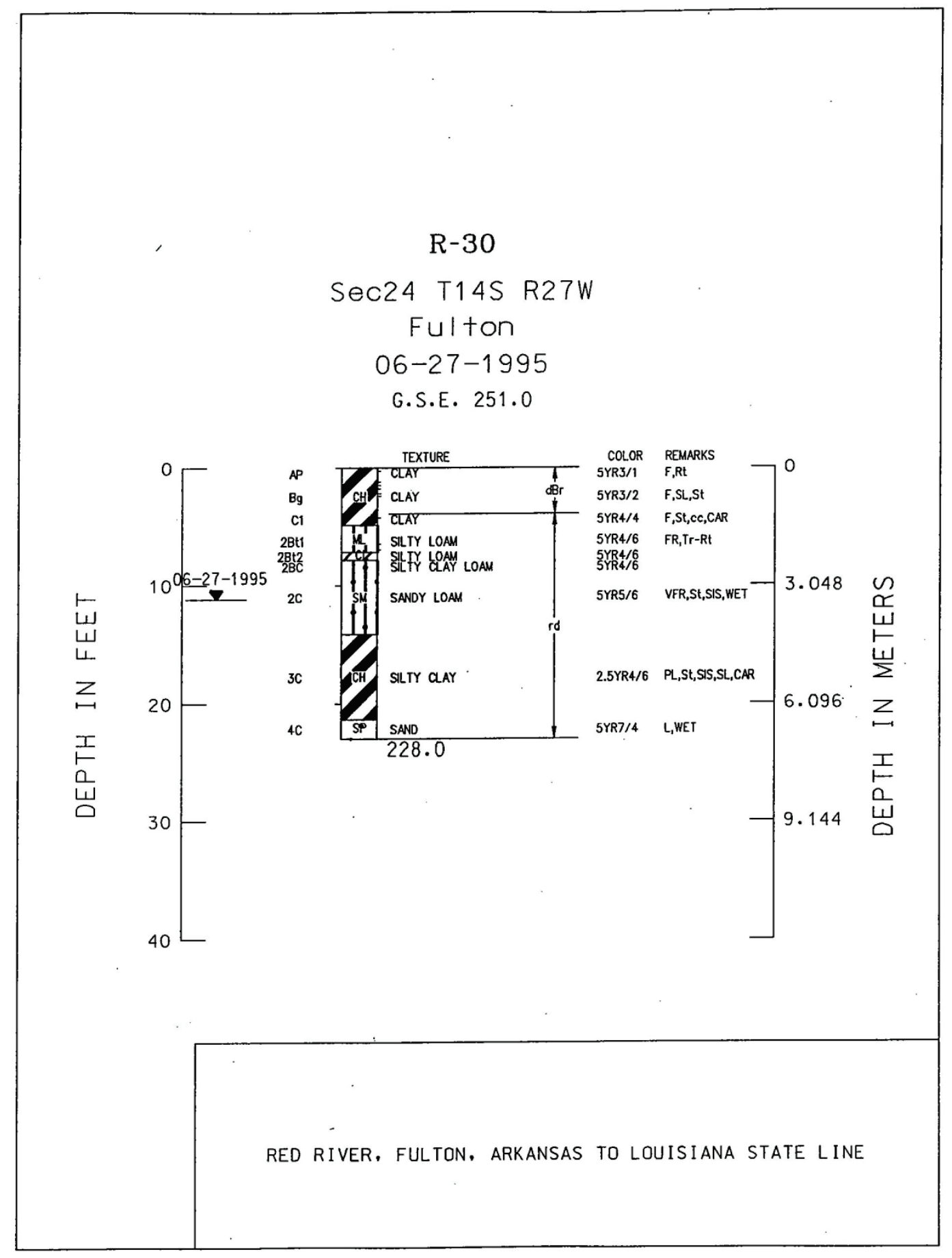




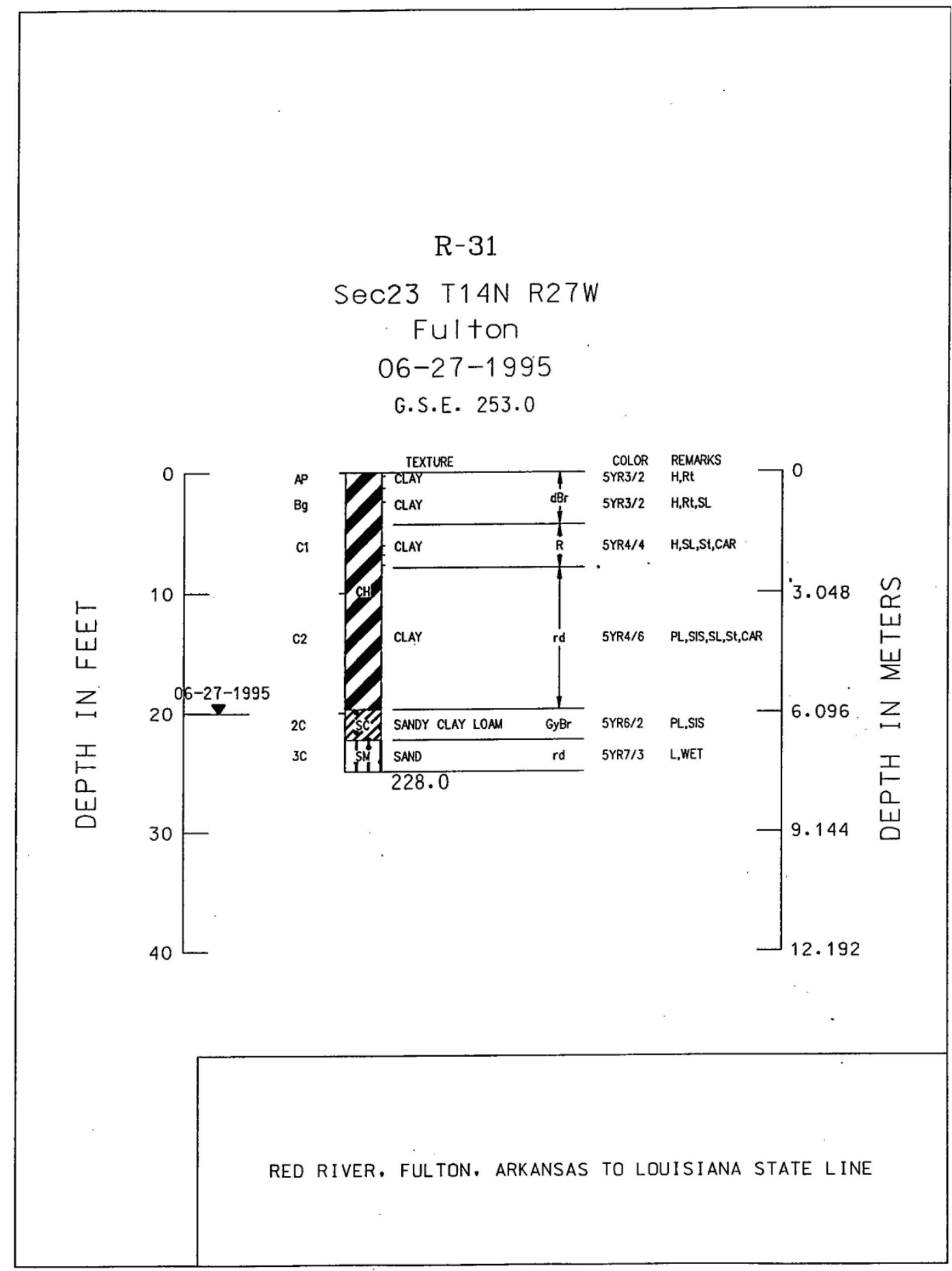




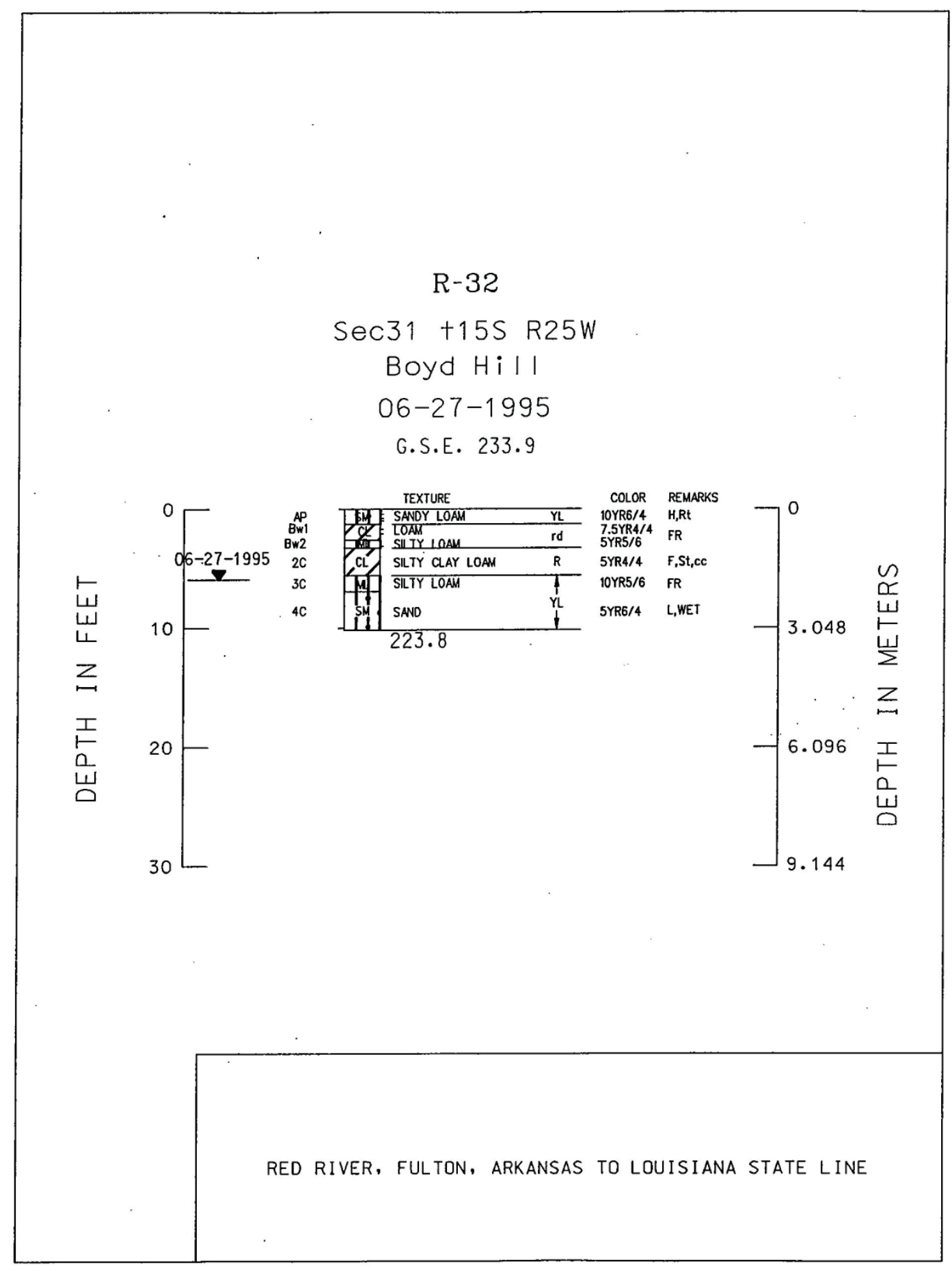




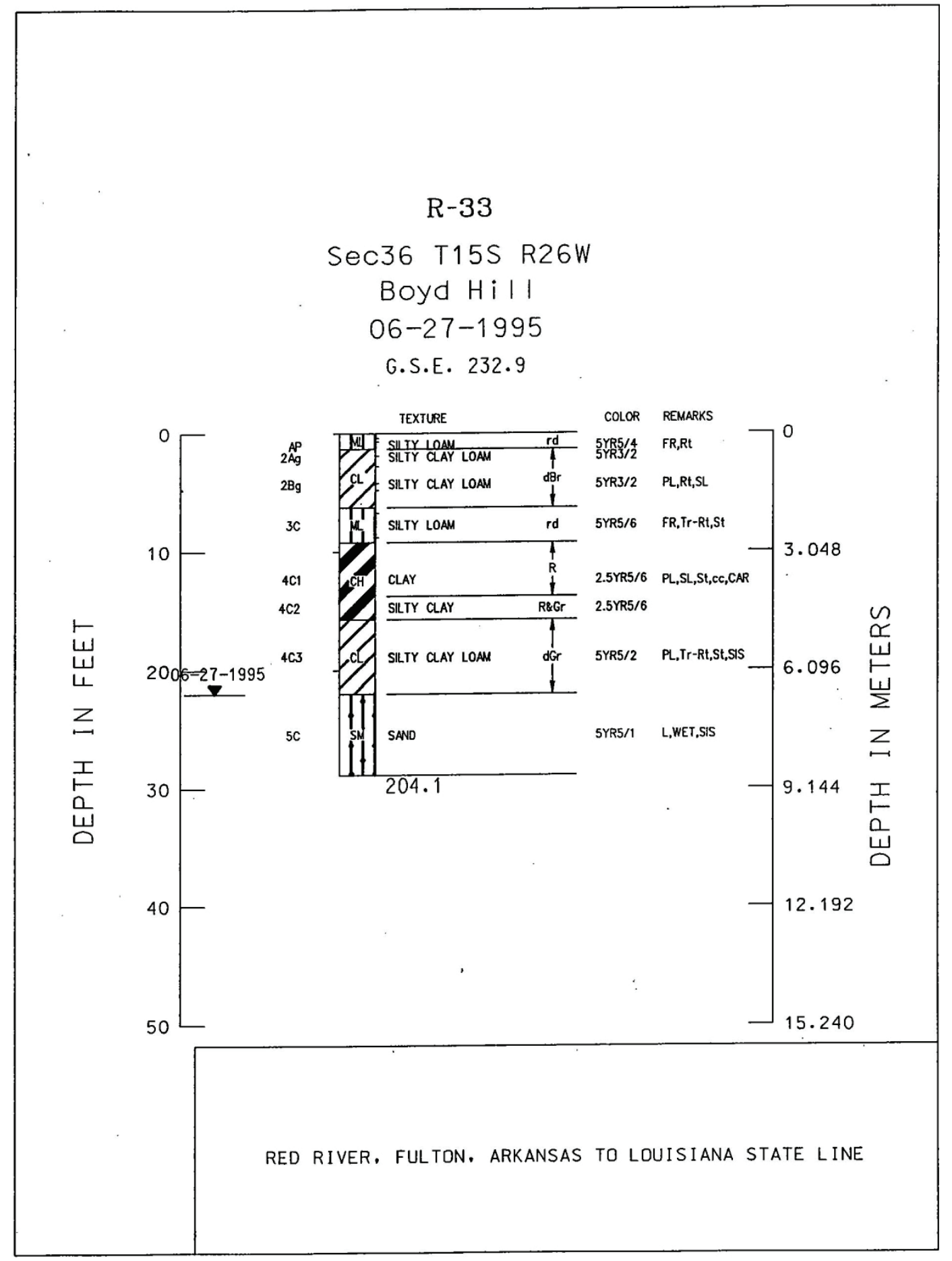




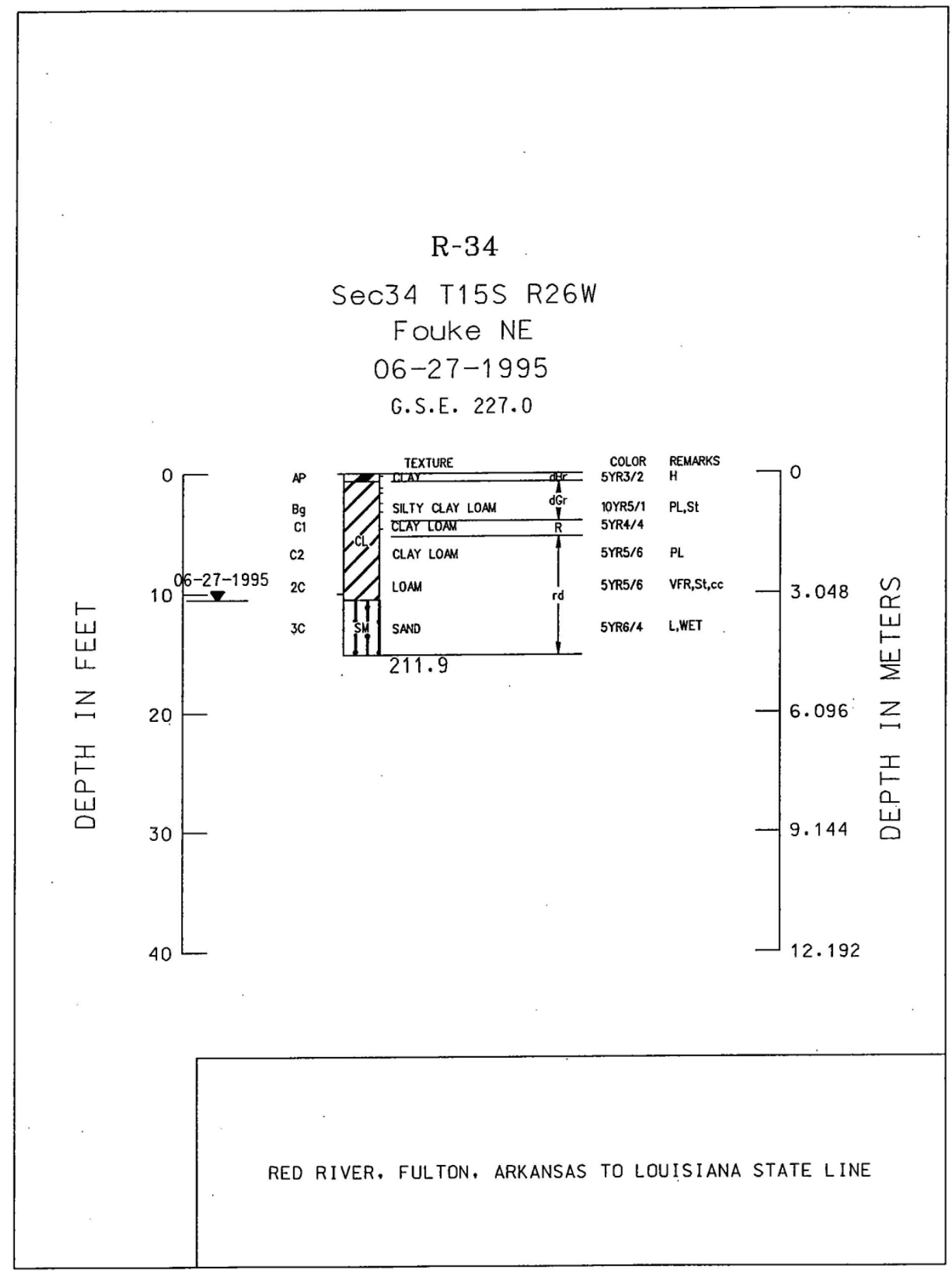




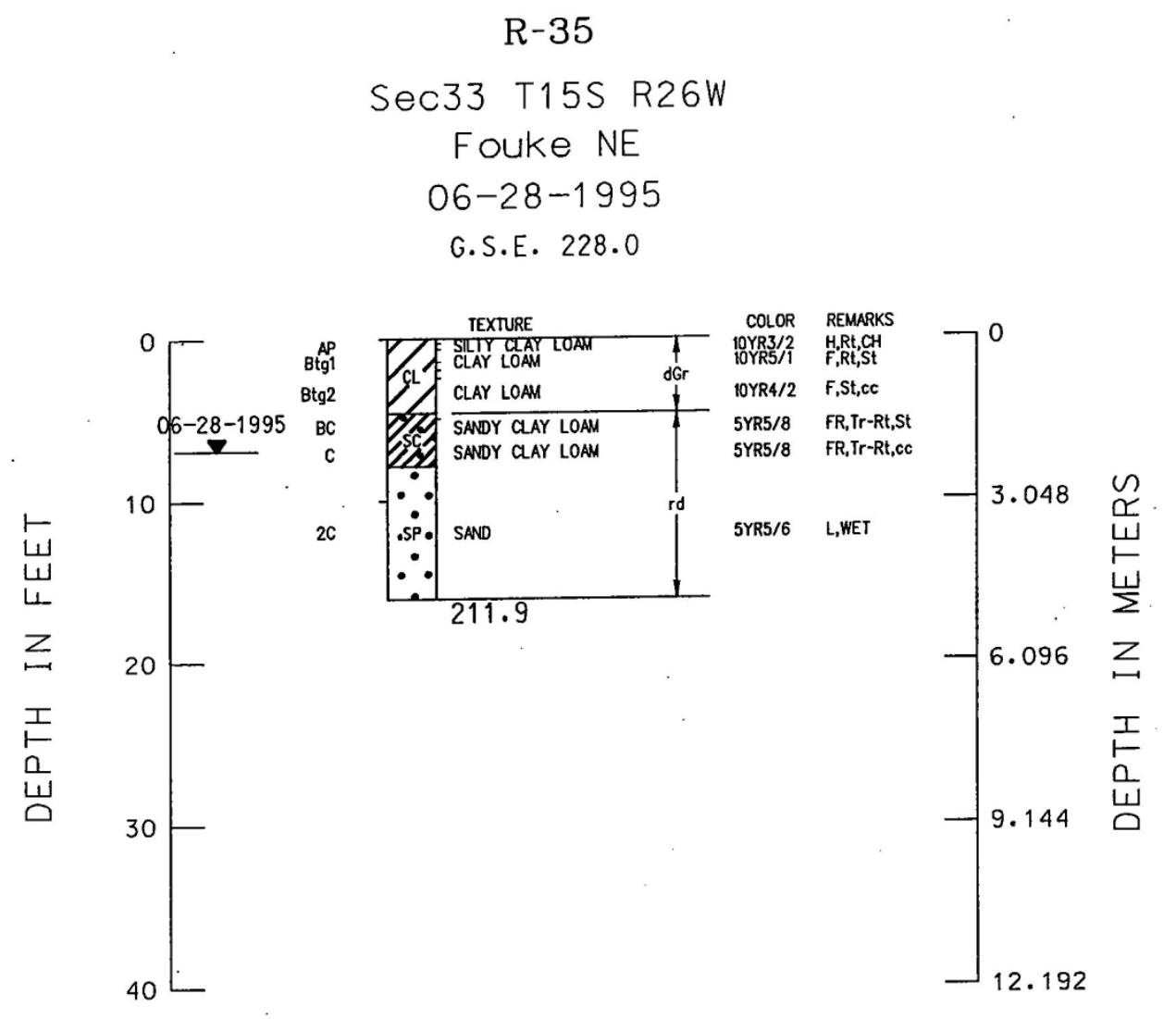

RED RIVER, FULTON, ARKANSAS TO LOUISIANA STATE LINE 


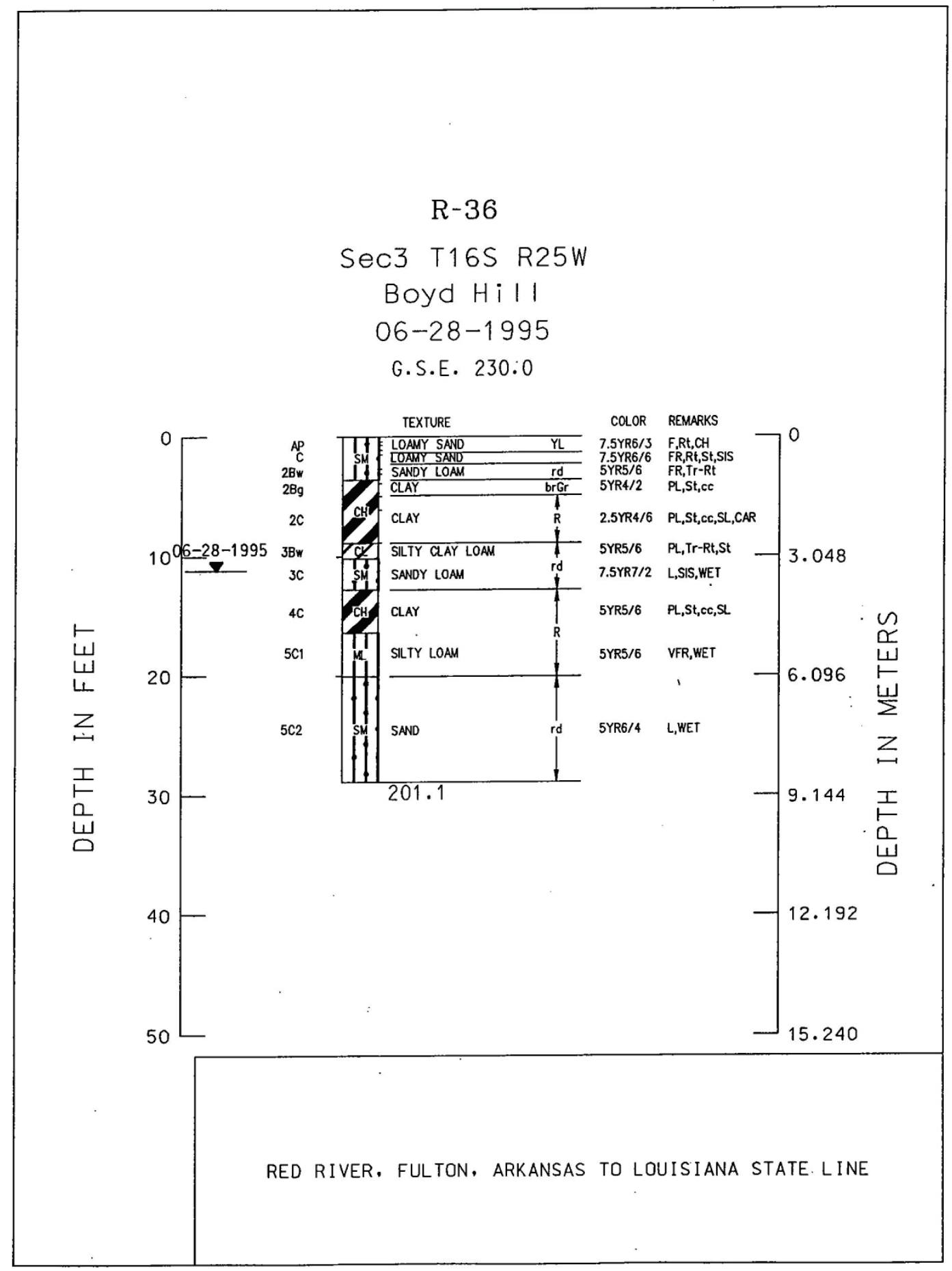




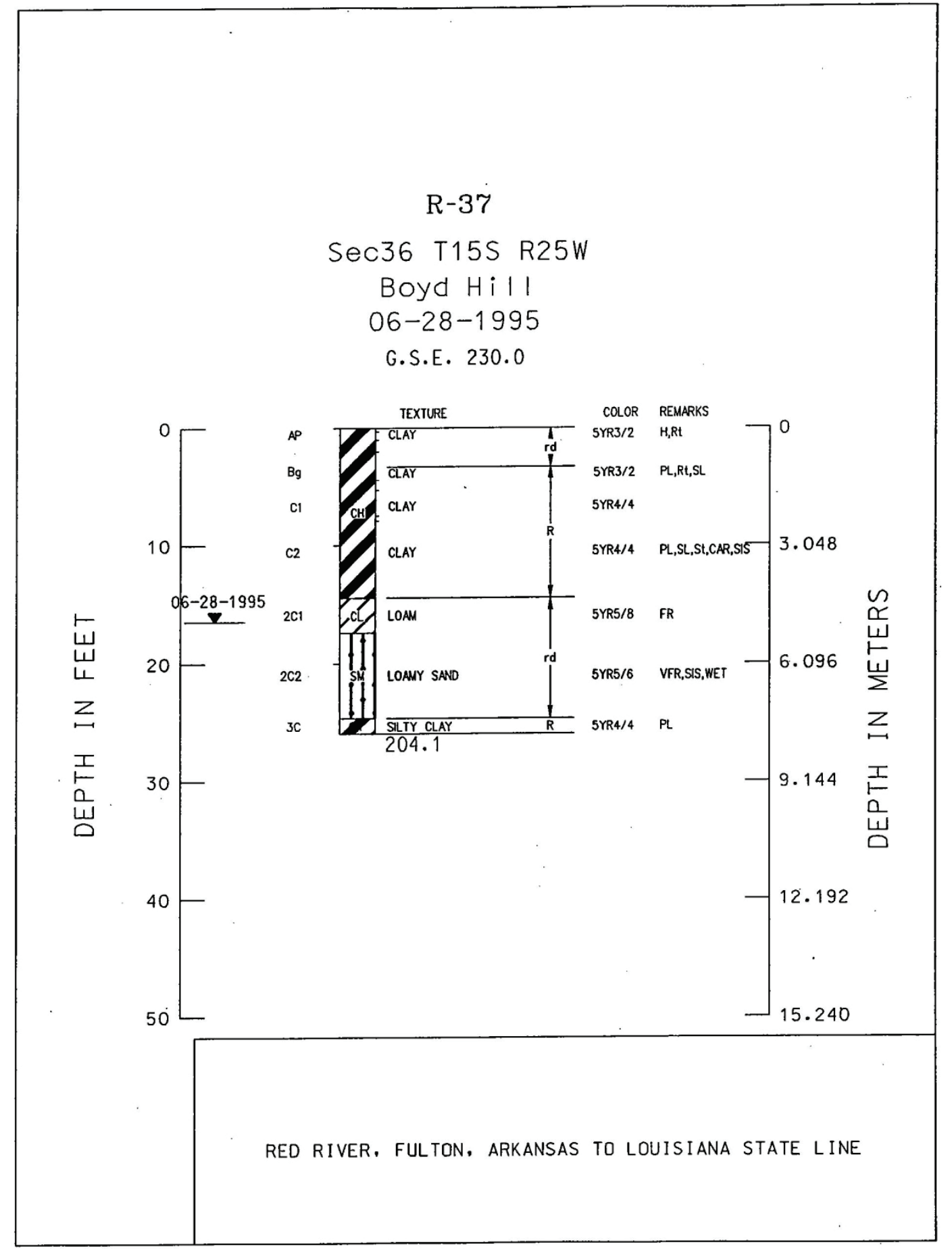




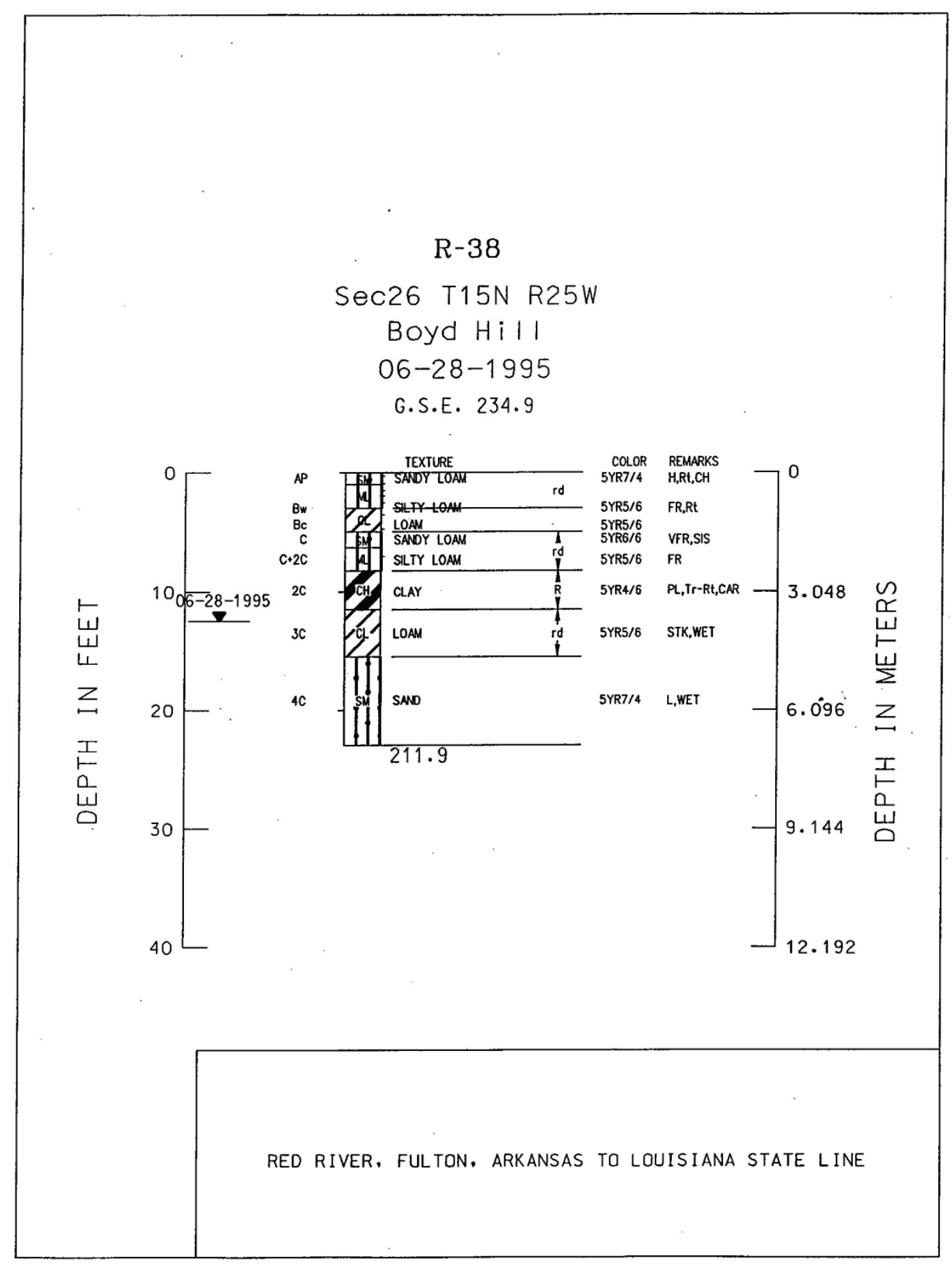




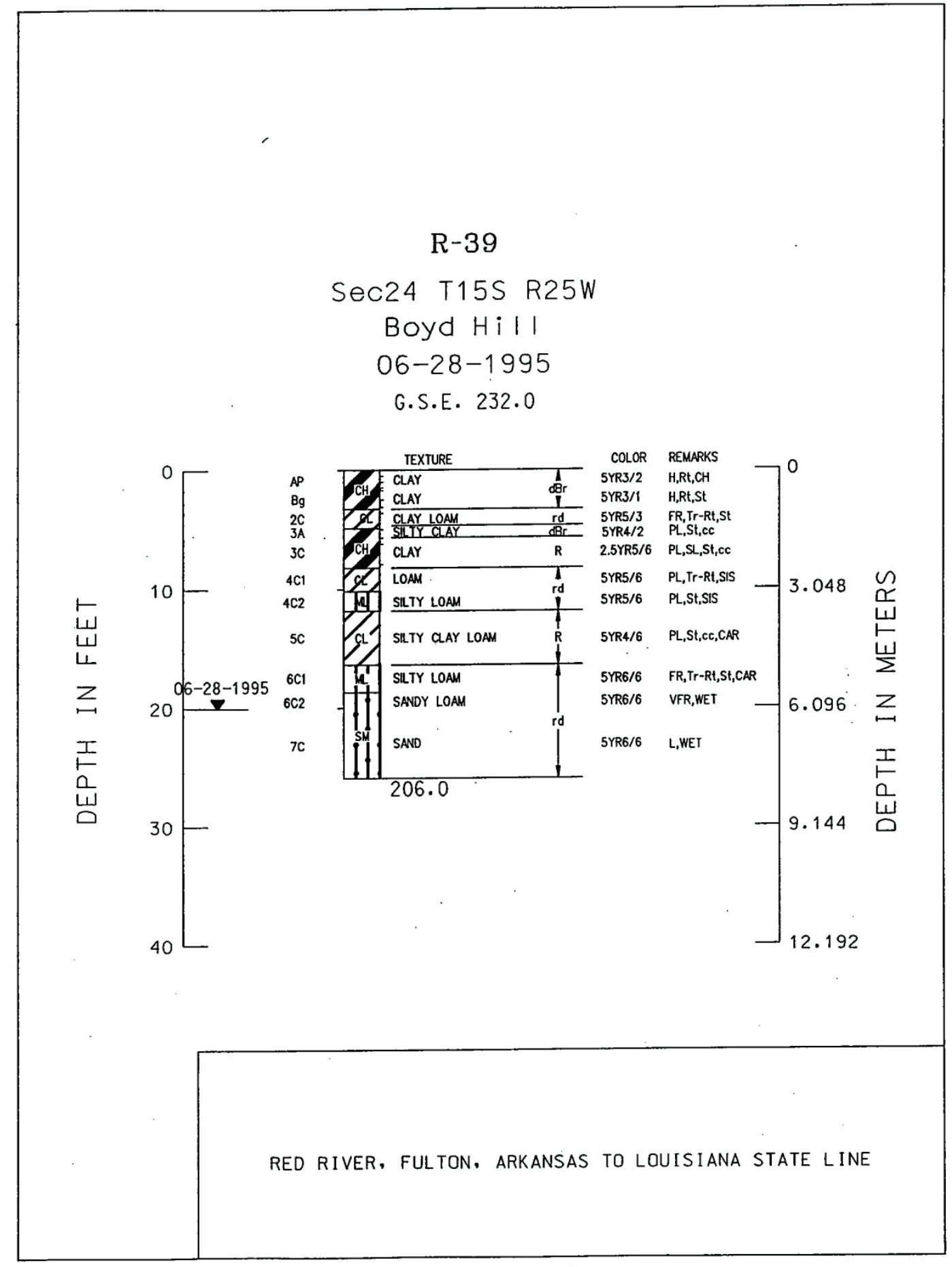




$$
\begin{gathered}
\text { R-40 } \\
\text { Sec27 T15S R25W } \\
\text { Boyd Hil I } \\
\text { O6-28-1995 } \\
\text { G.S.E. } 237.9
\end{gathered}
$$

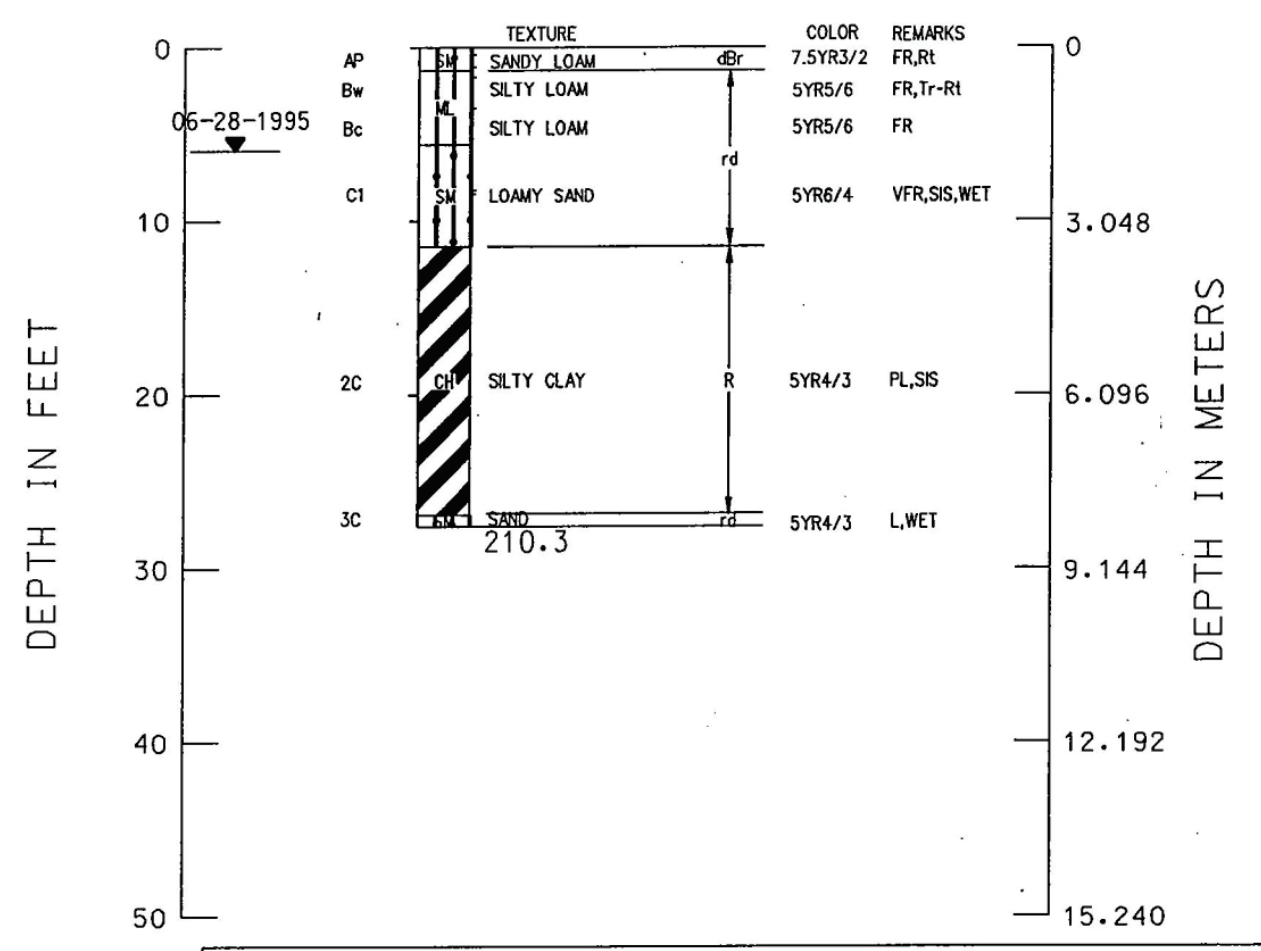

RED RIVER, FULTON, ARKANSAS TO LOUISIANA STATE LINE 


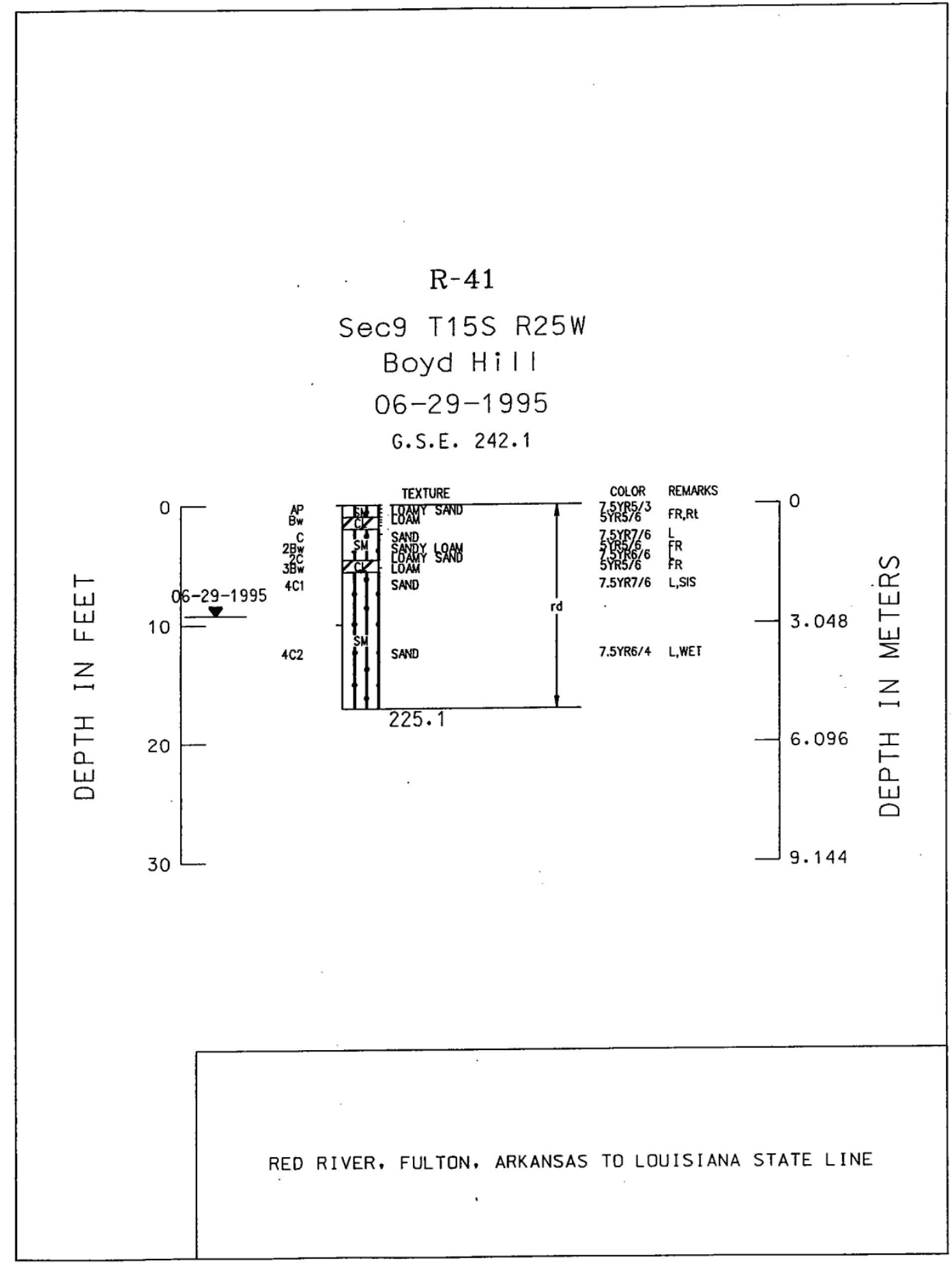




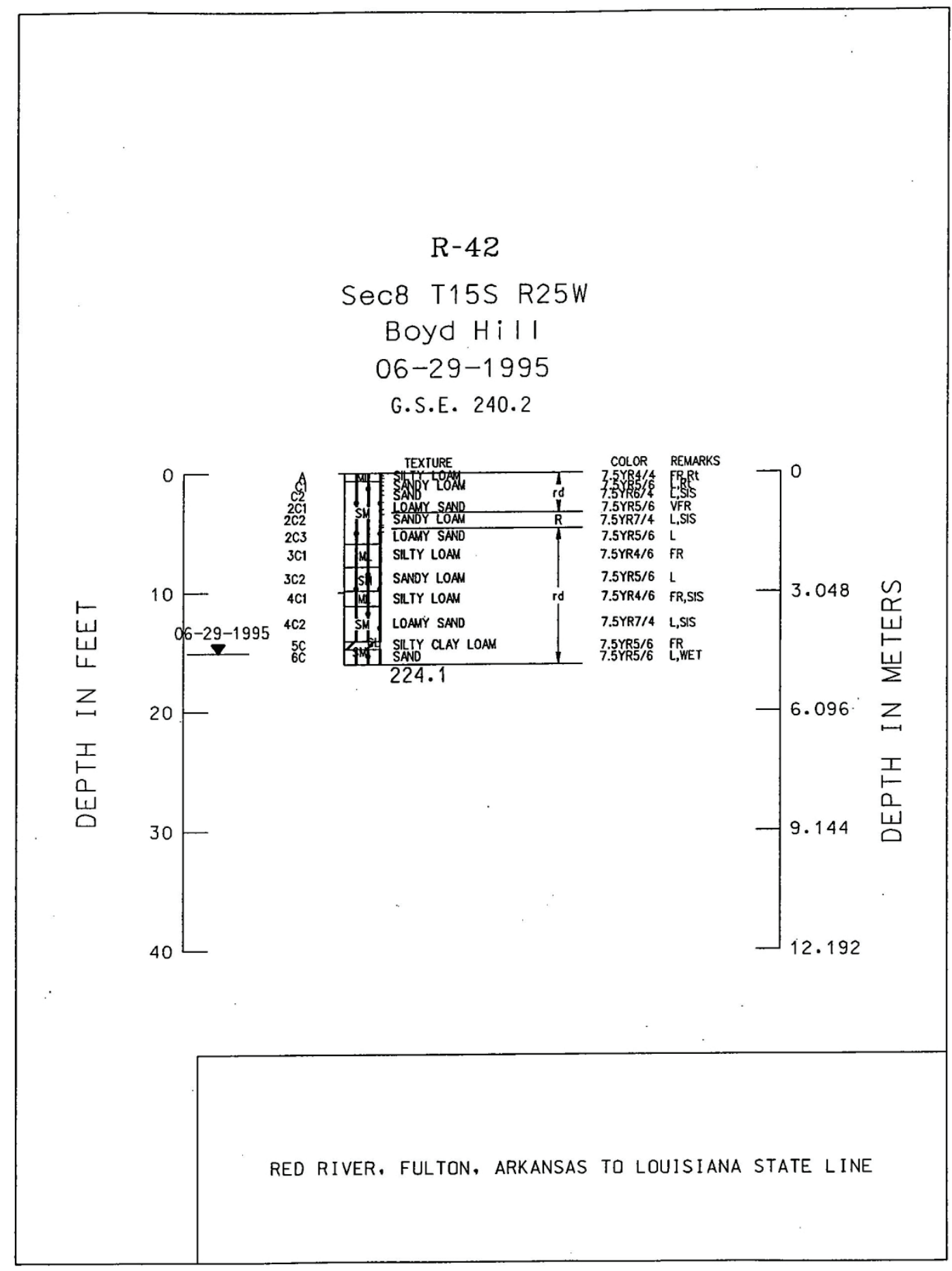




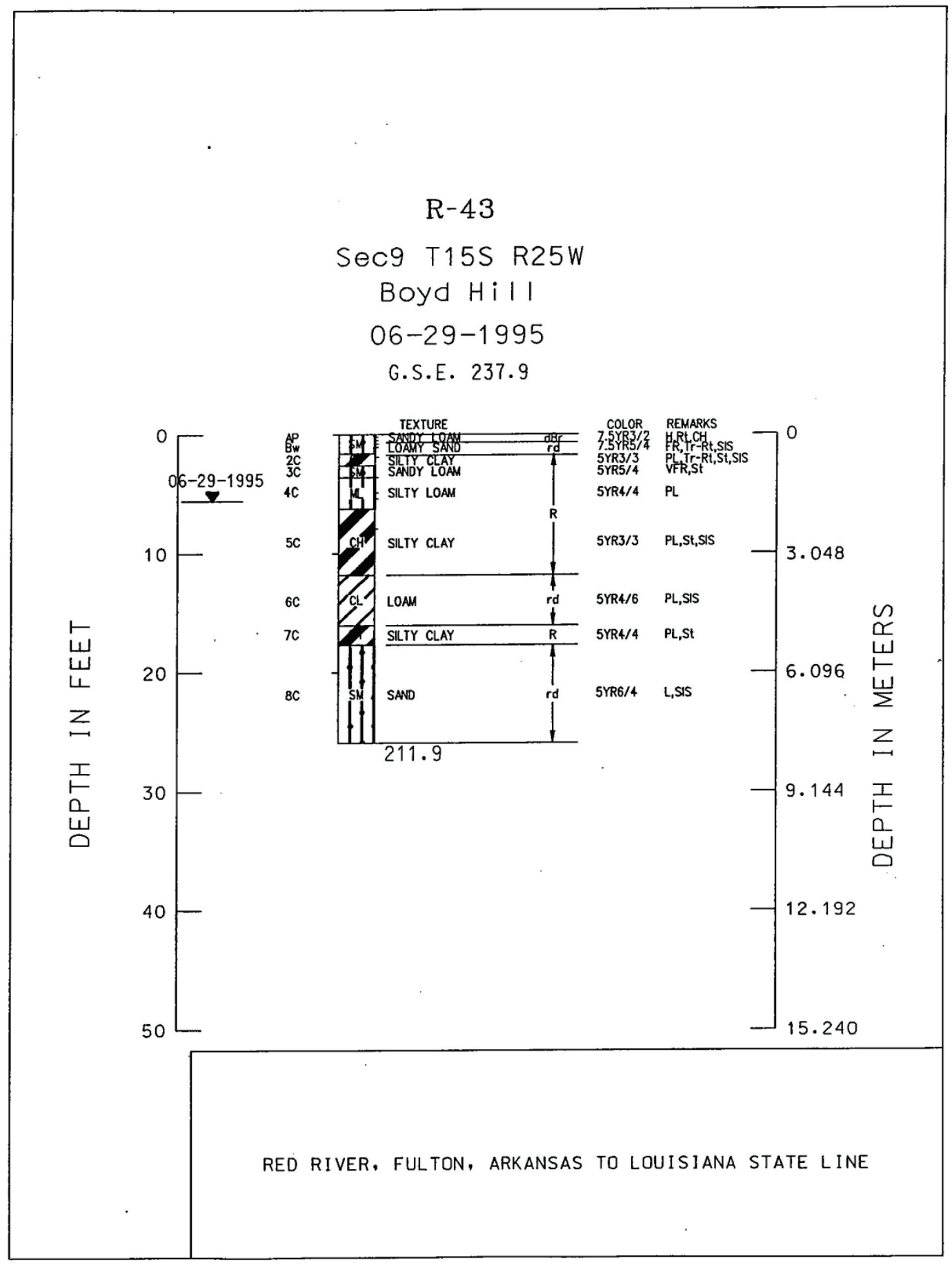




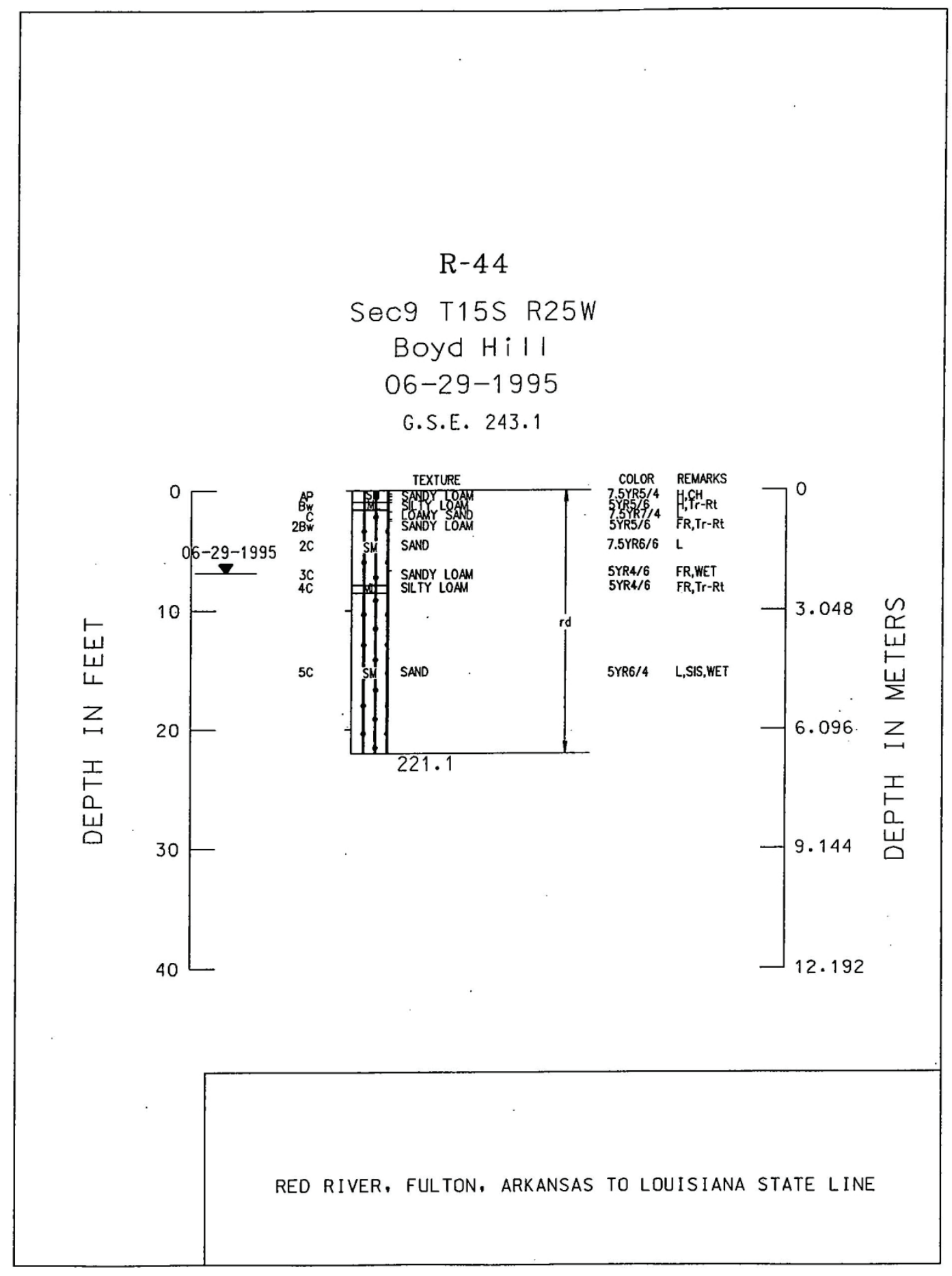




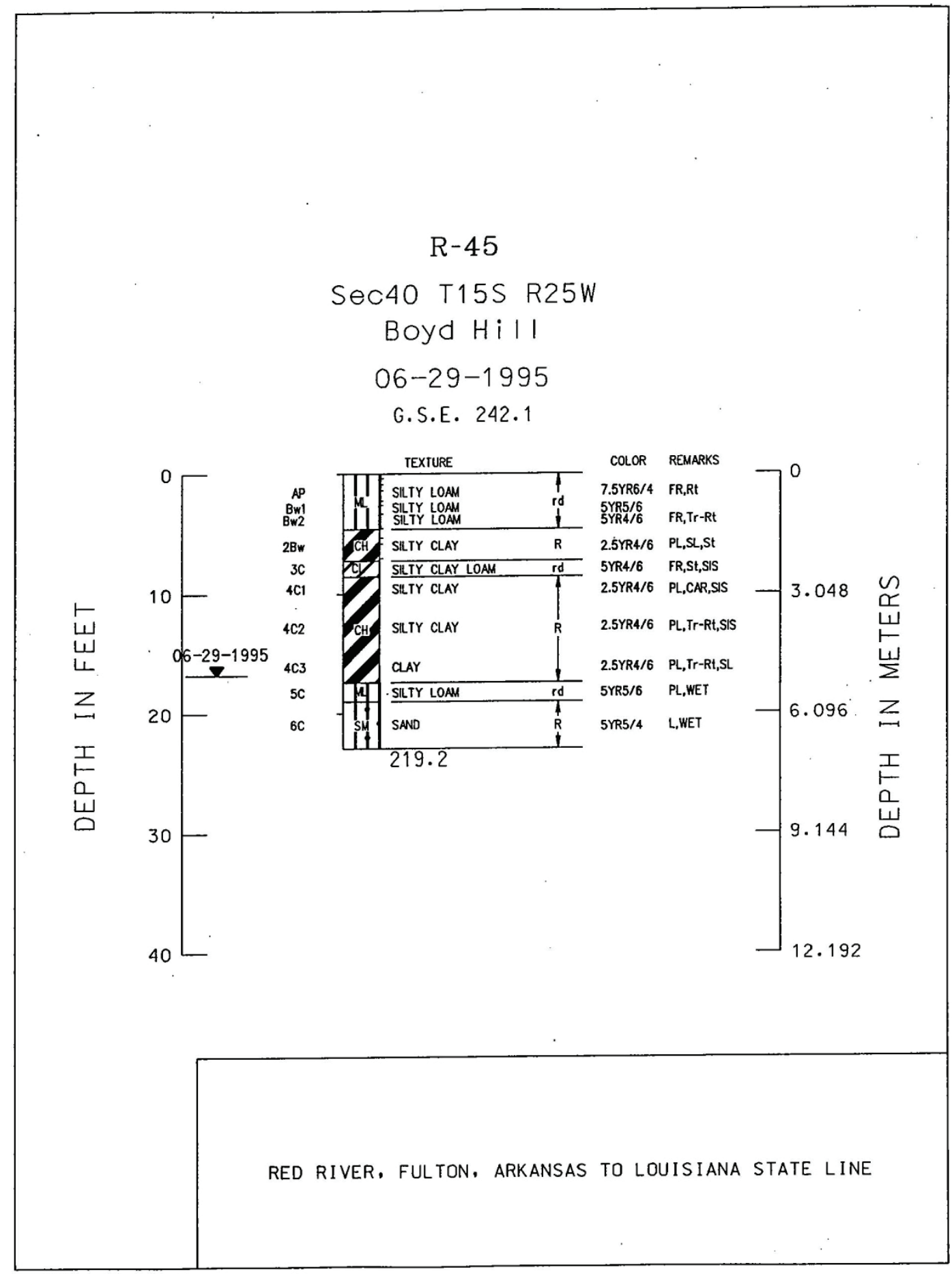




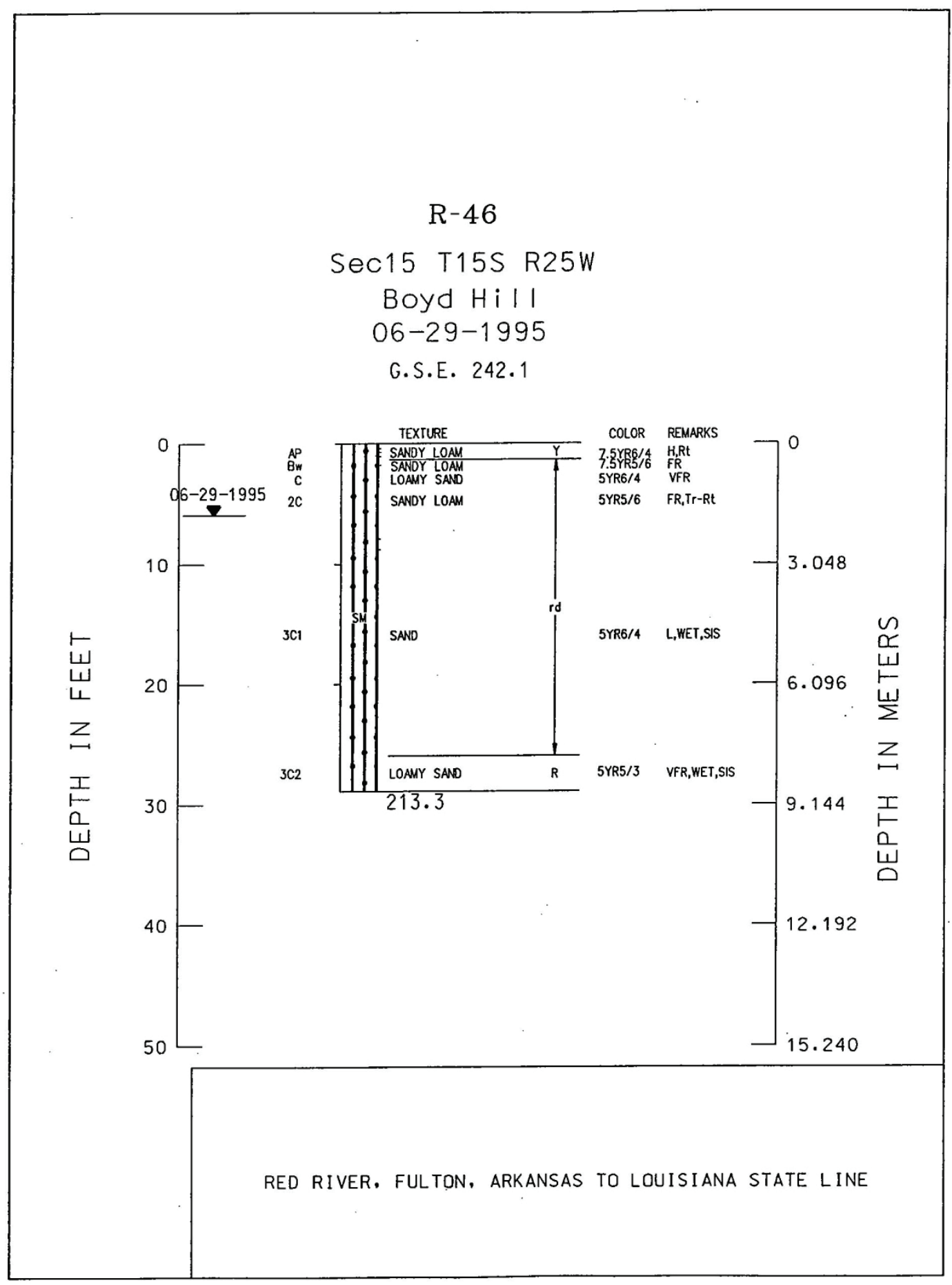




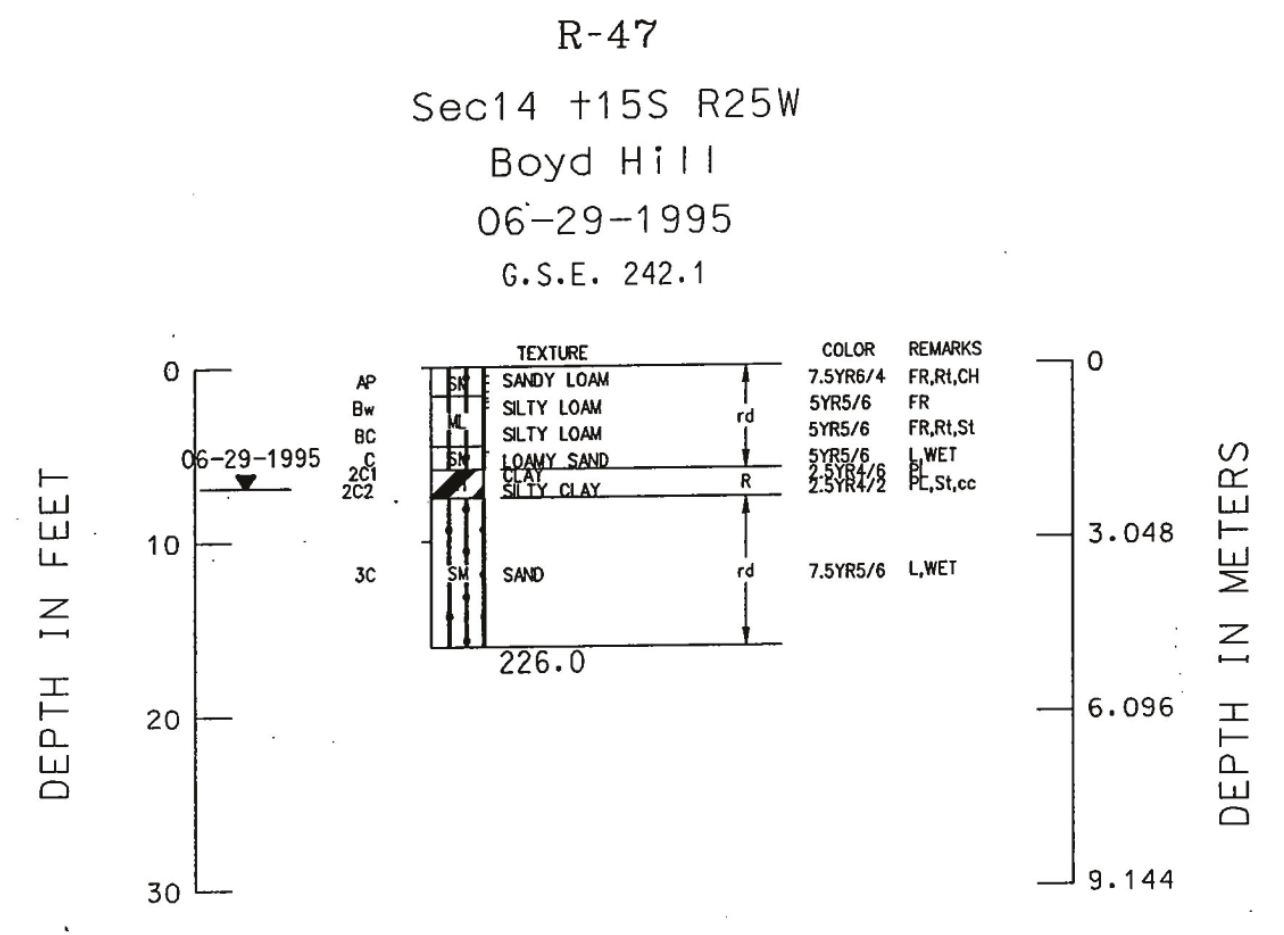

RED RIVER, FULTON, ARKANSAS TO LOUISIANA STATE LINE 


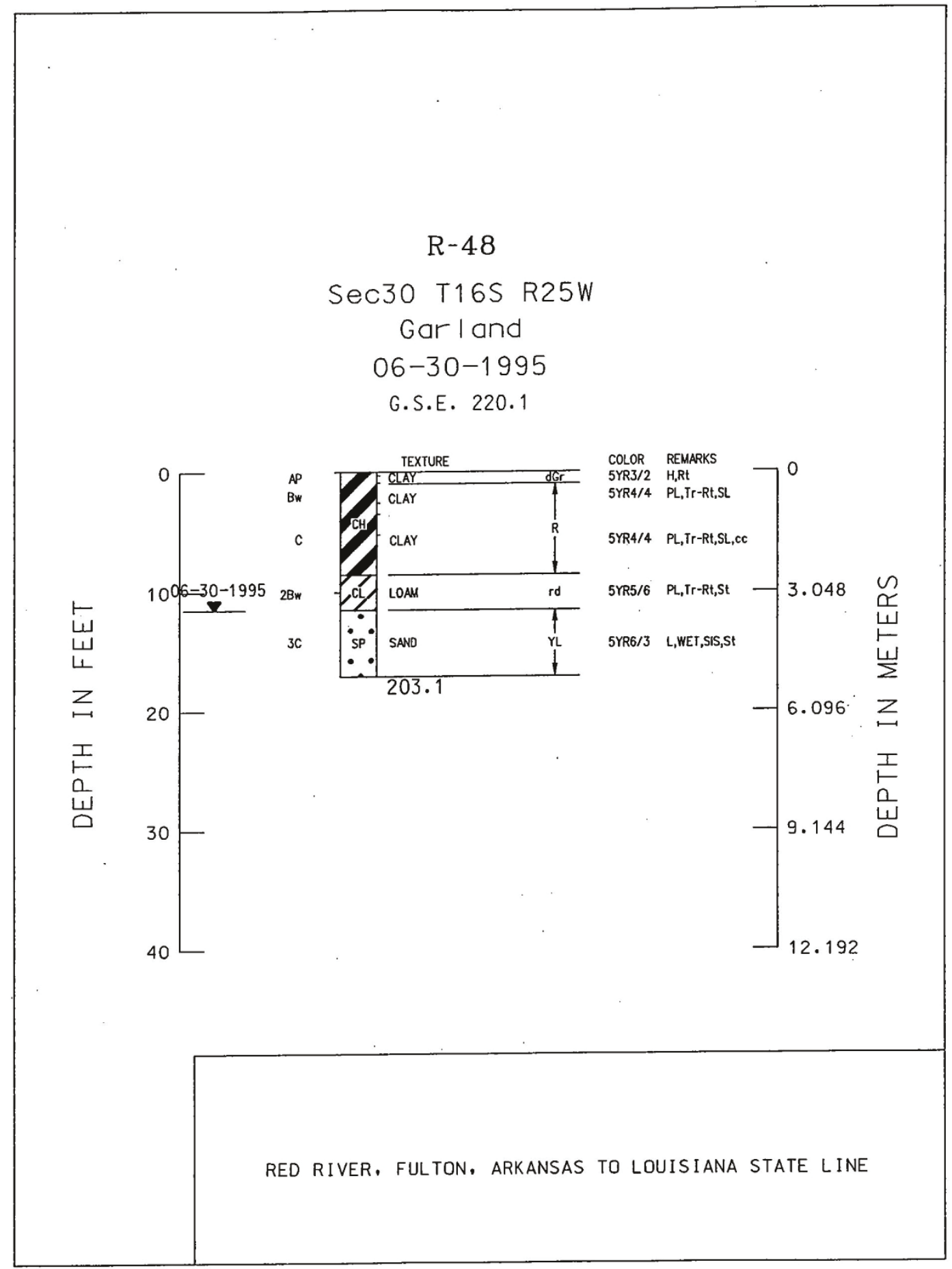




$$
\begin{gathered}
\text { R-49 } \\
\text { Sec29 T16S R25W } \\
\text { Gar l and } \\
\text { O7-17-1995 } \\
\text { G.S.E. } 227.0
\end{gathered}
$$

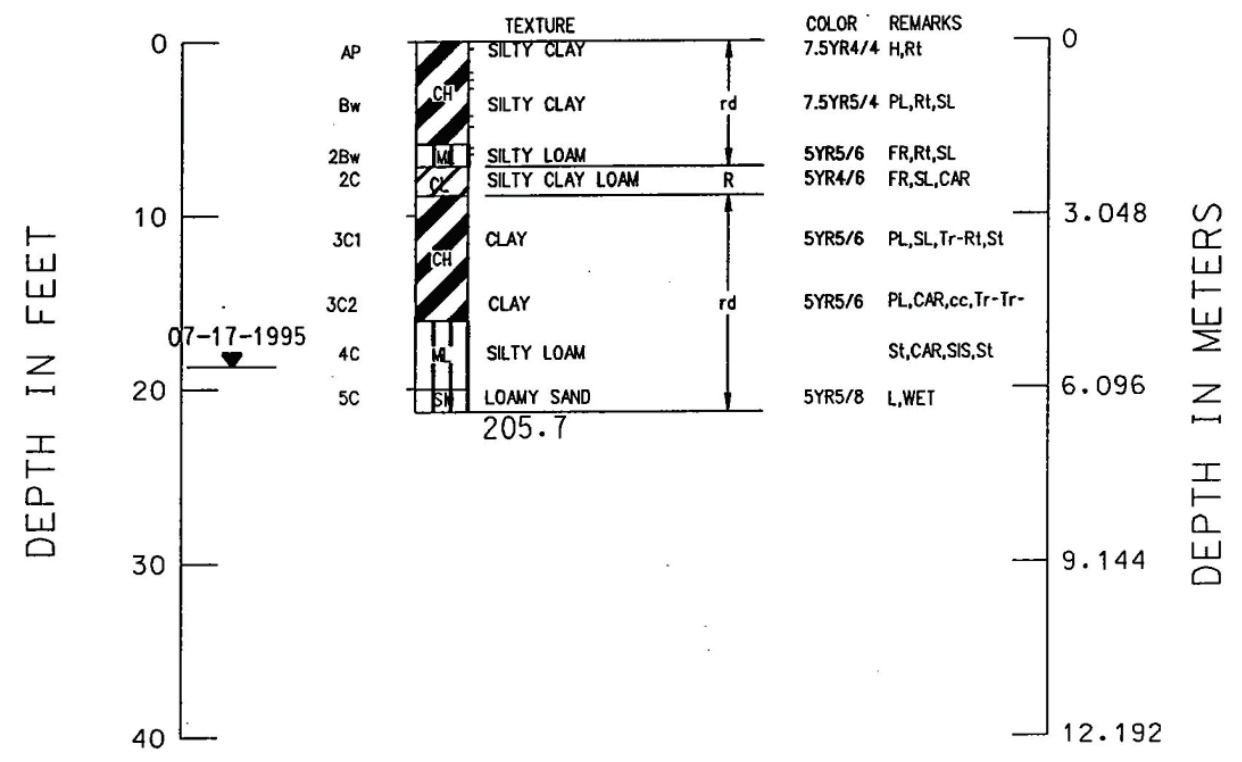

RED RIVER, FULTON, ARKANSAS TO LOUISIANA STATE LINE 


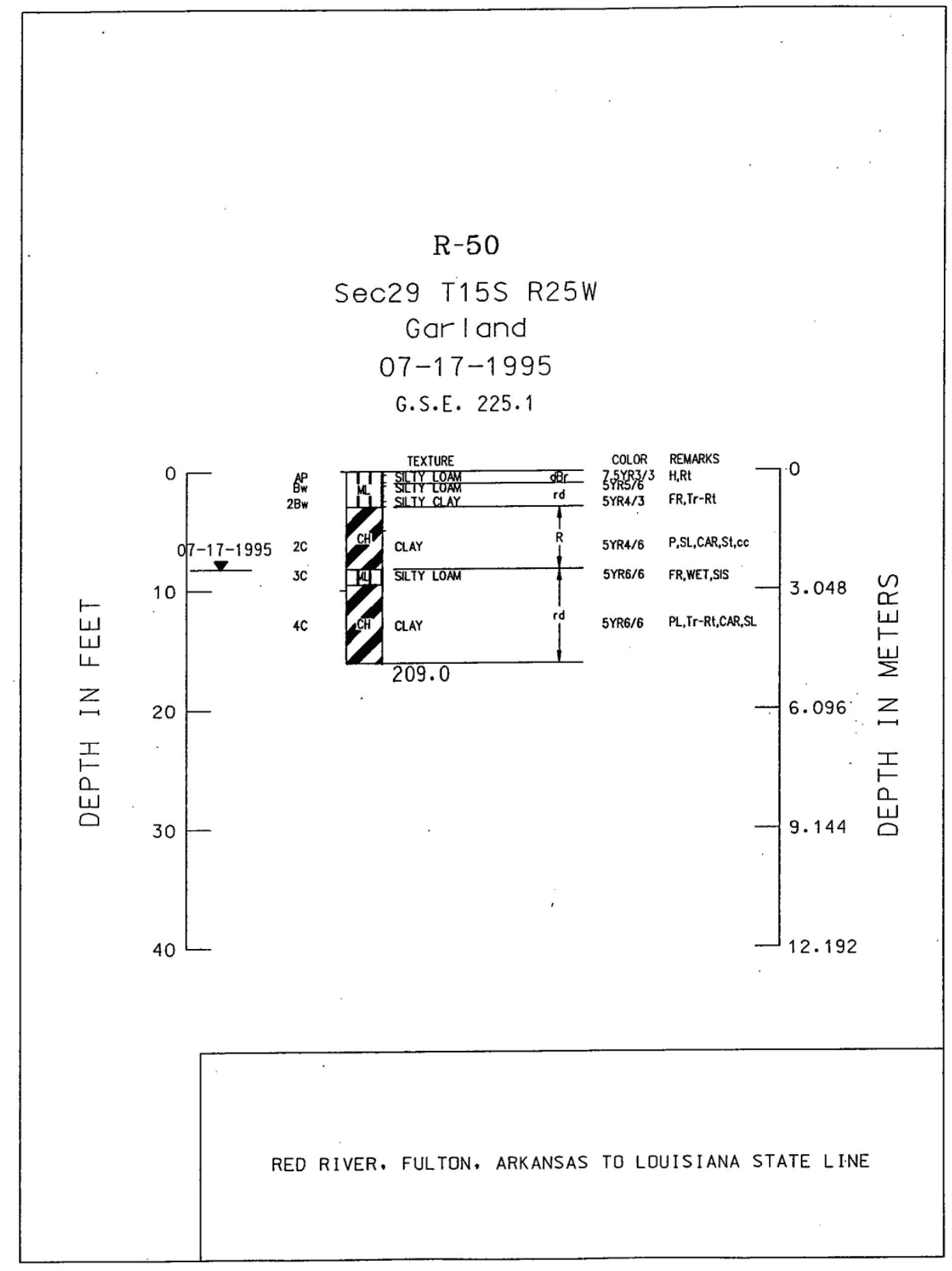




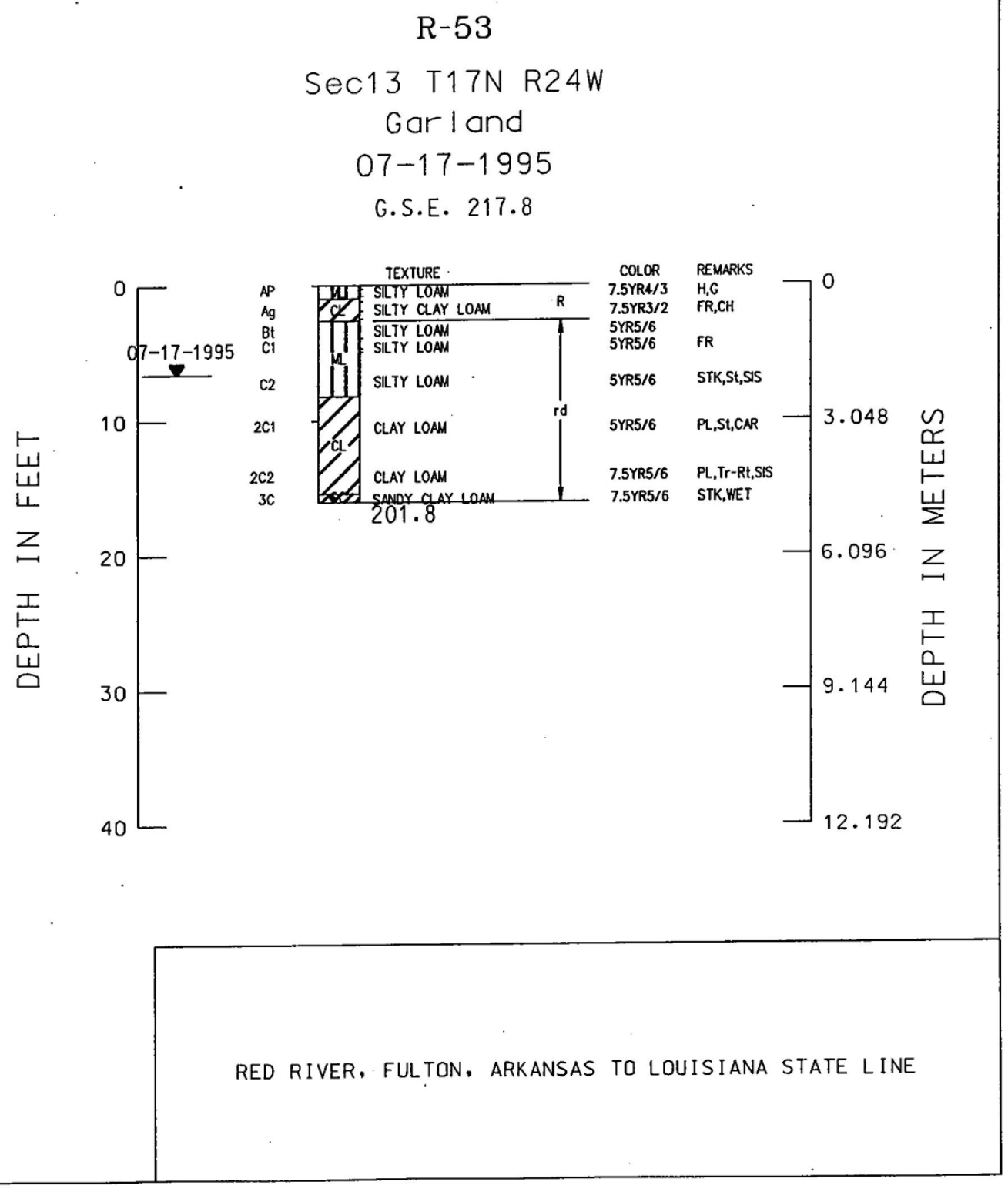




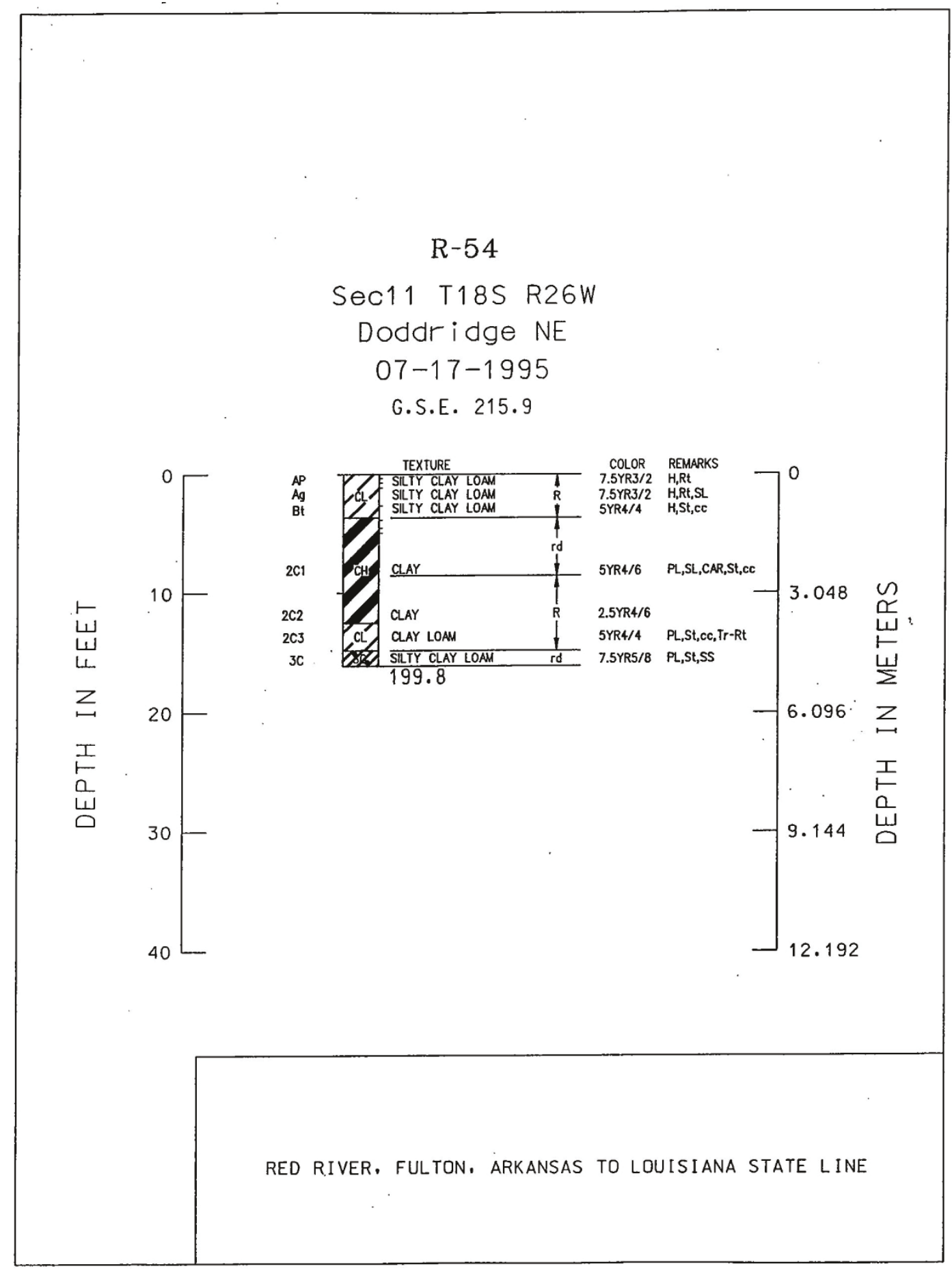




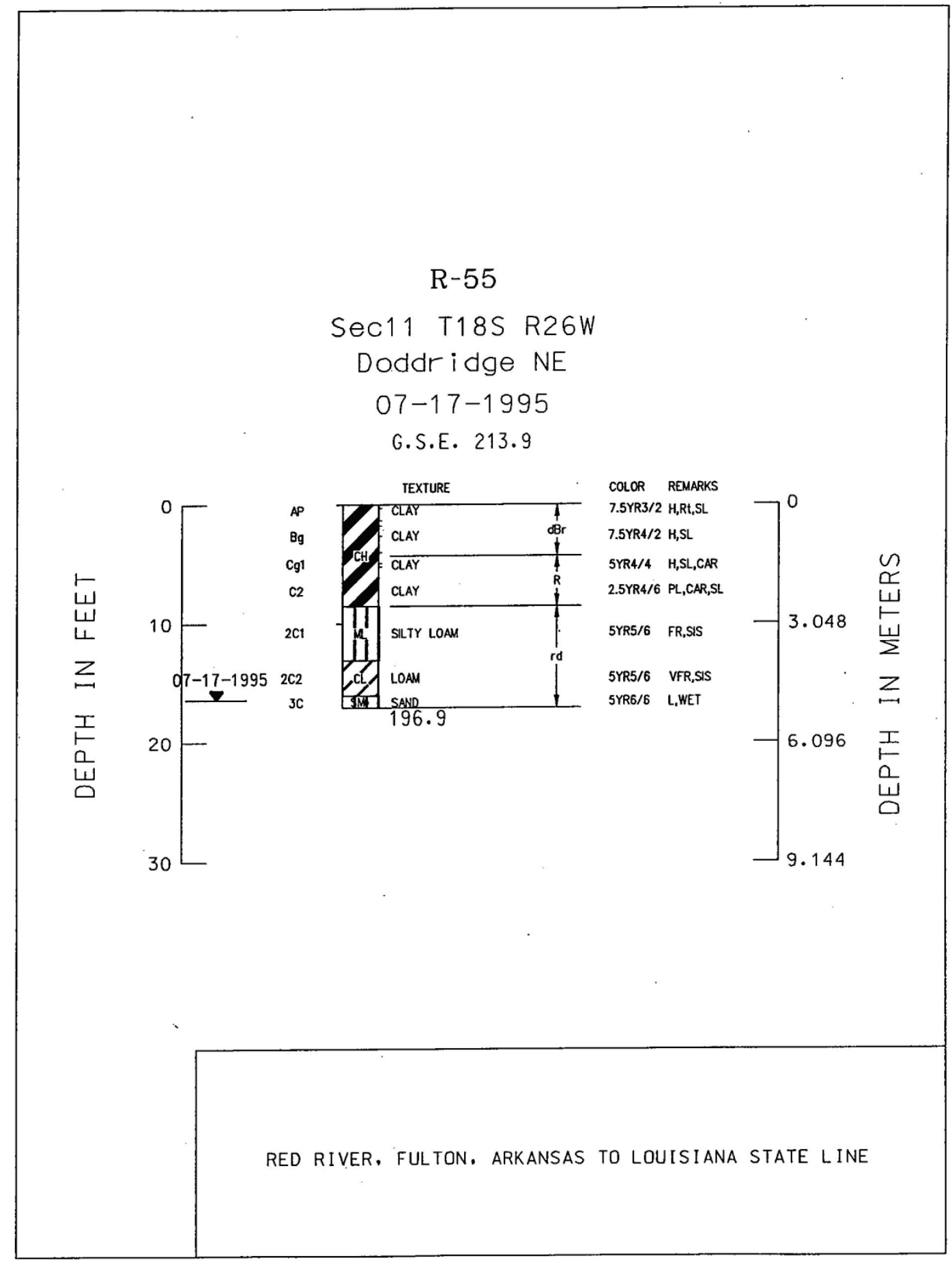




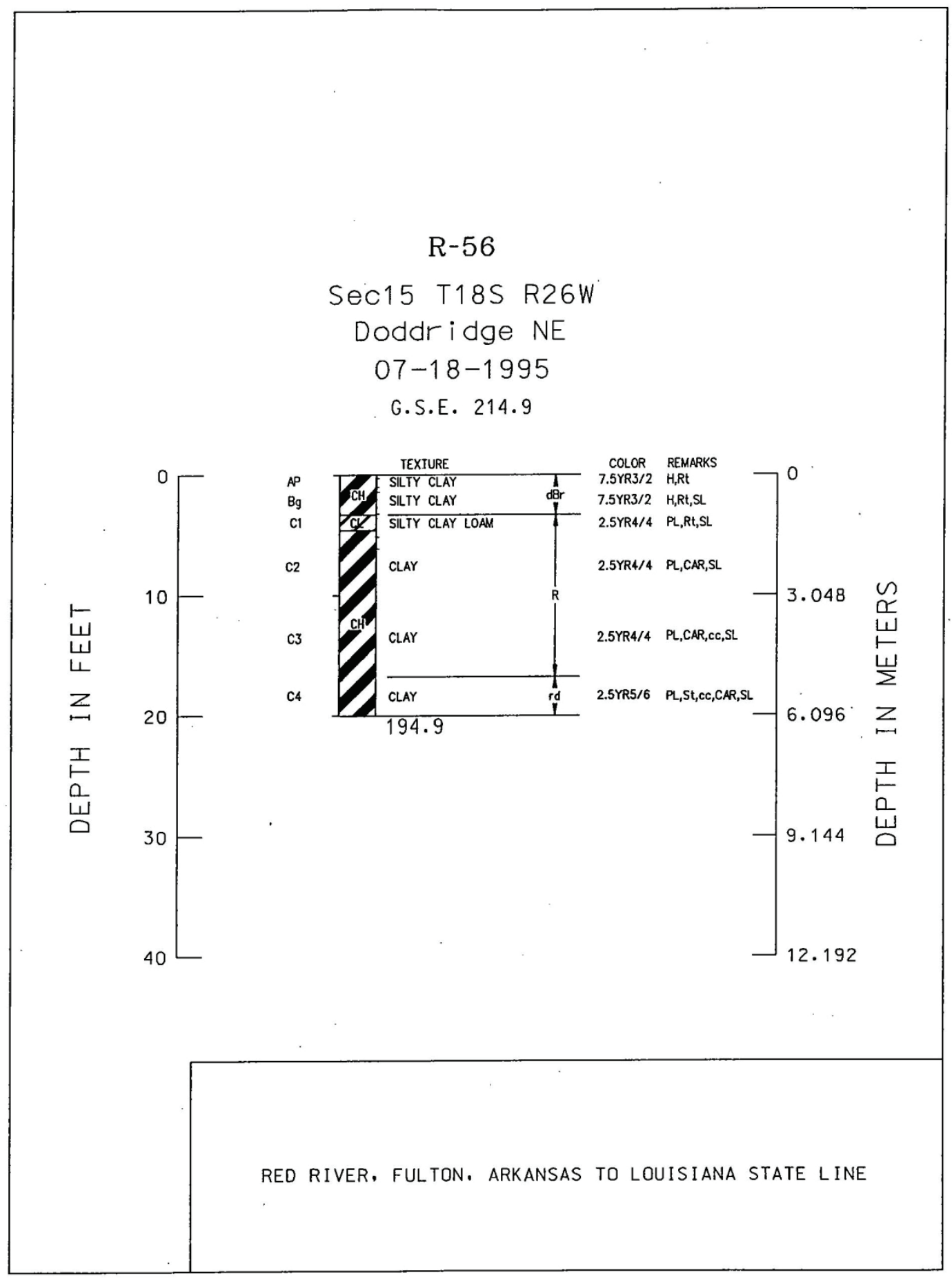




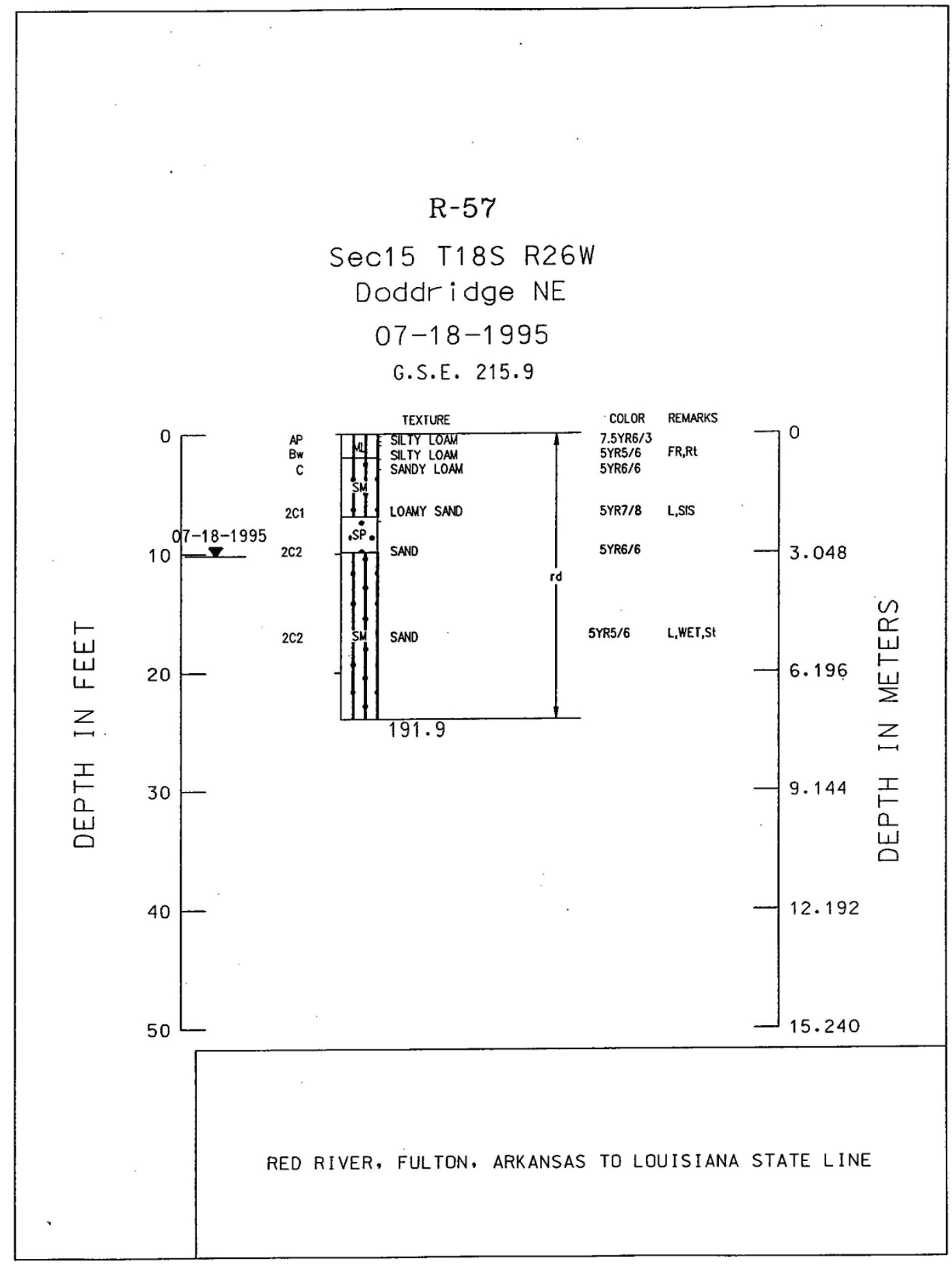




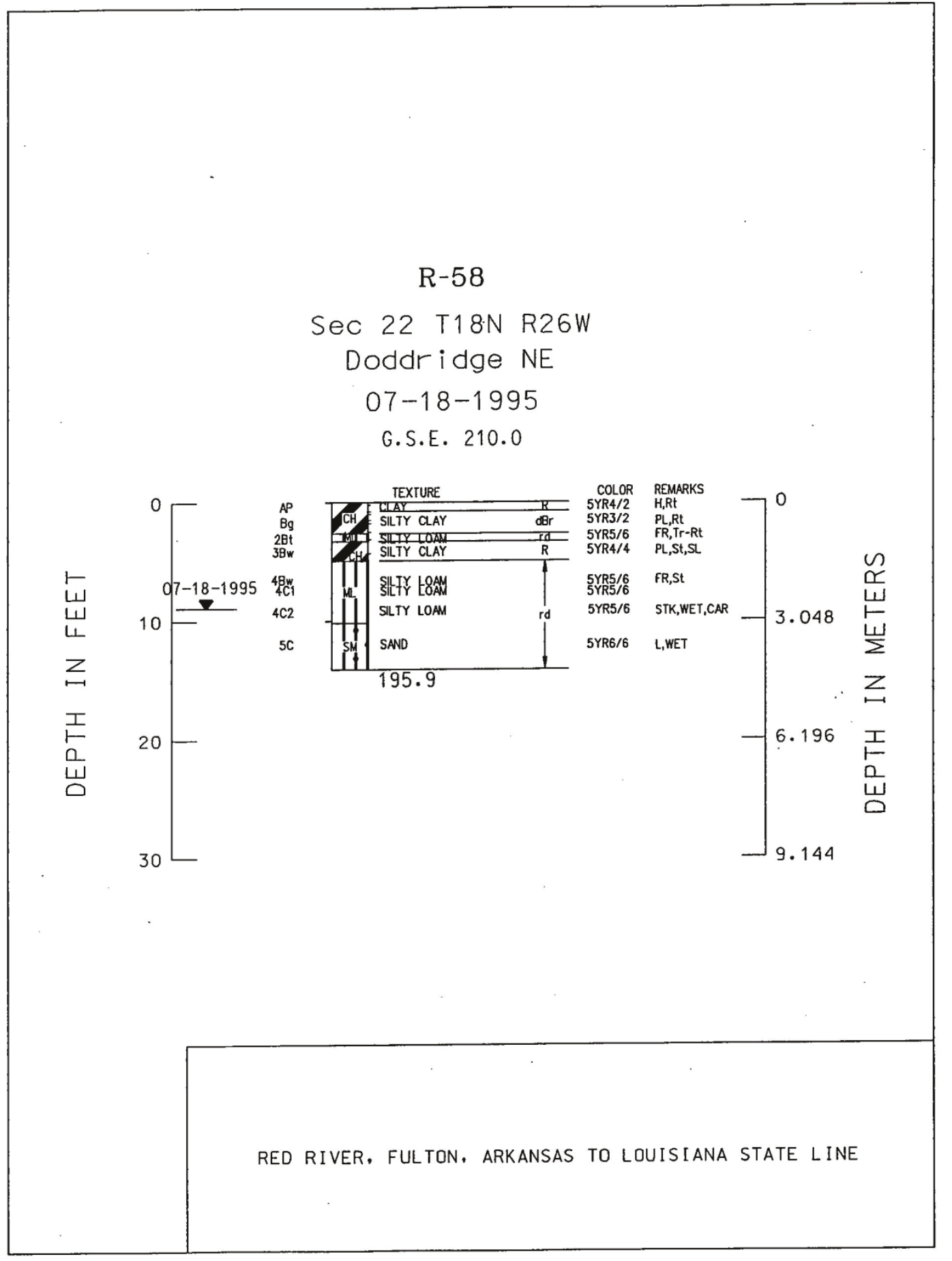




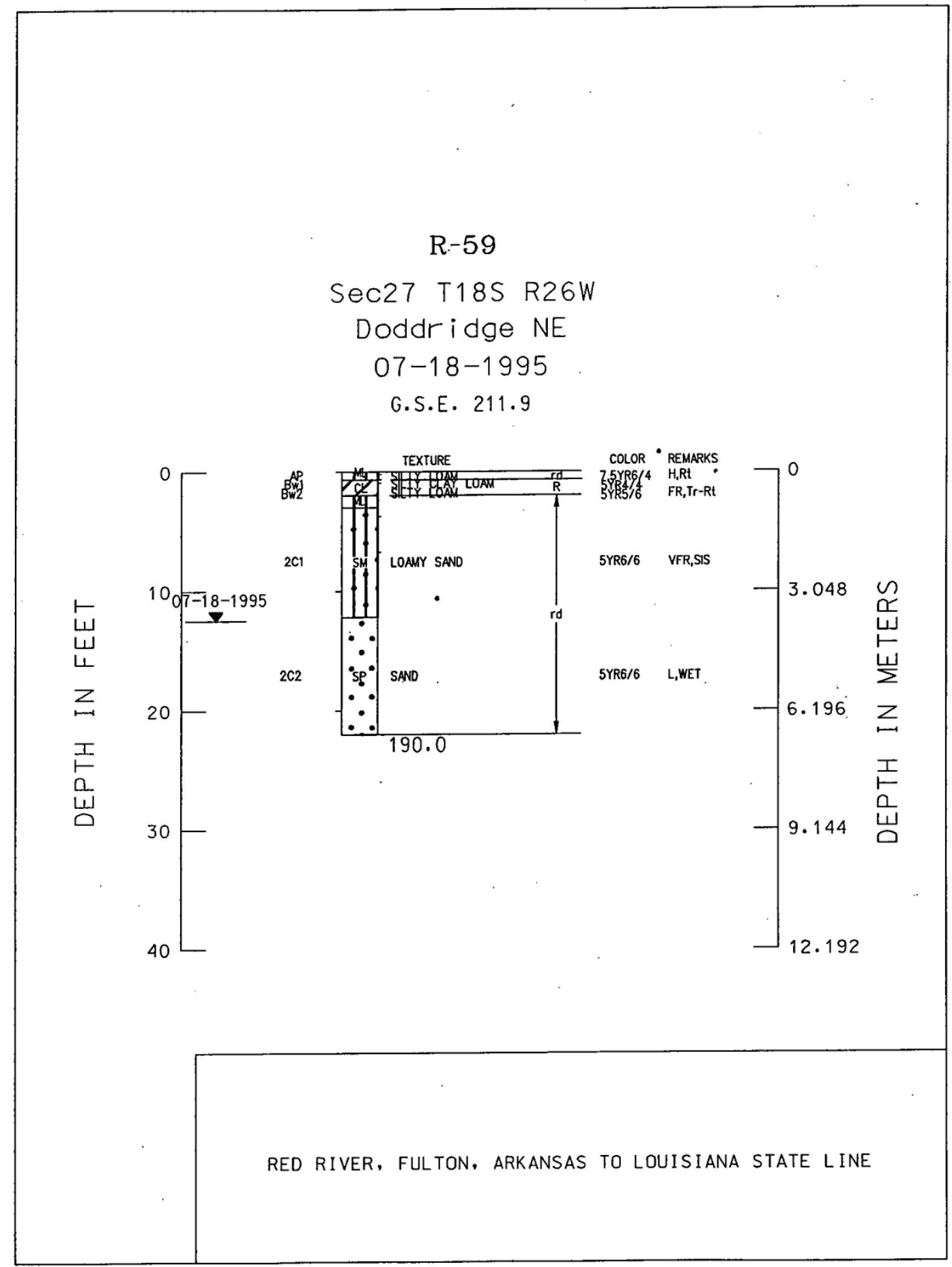




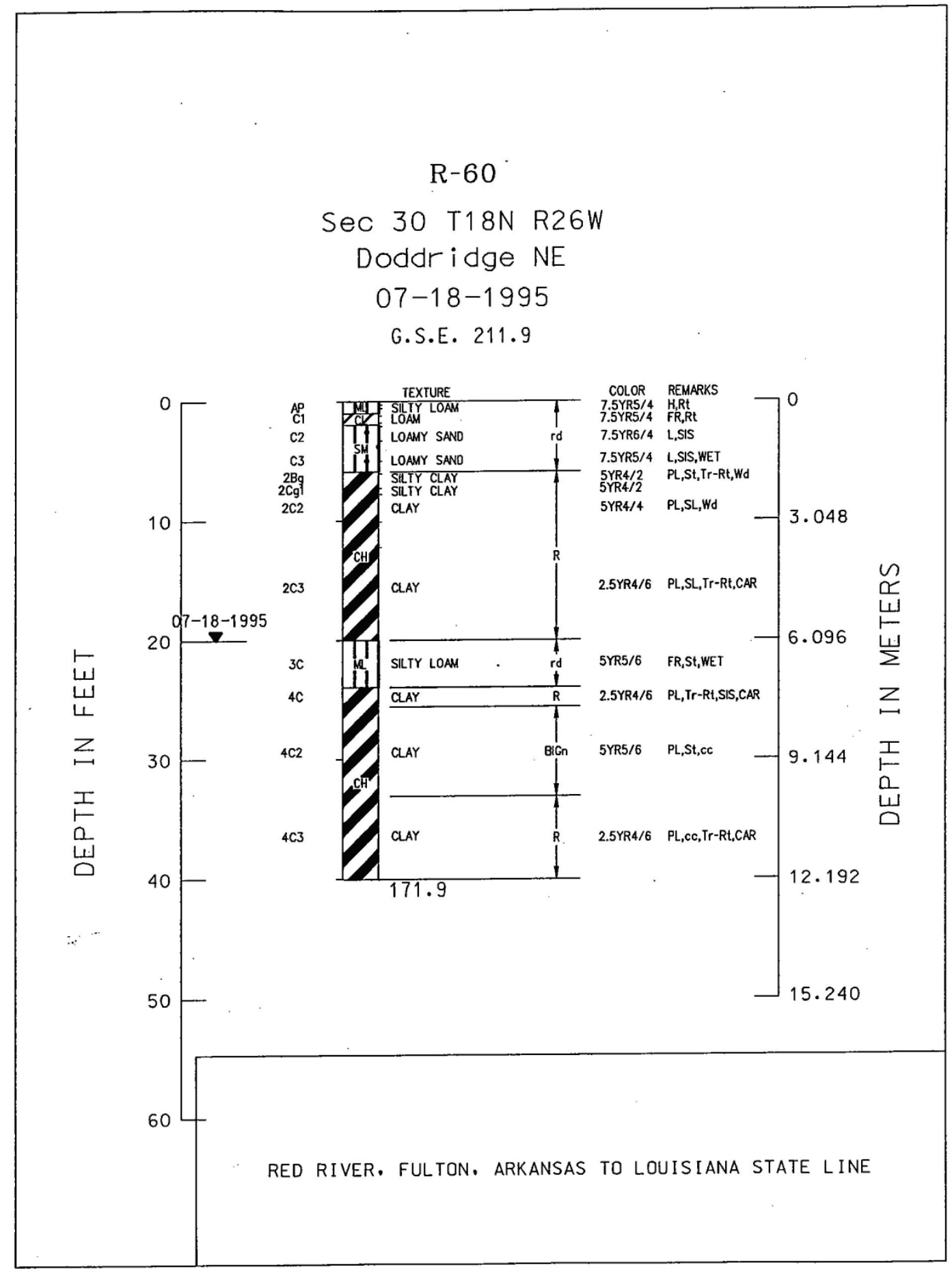




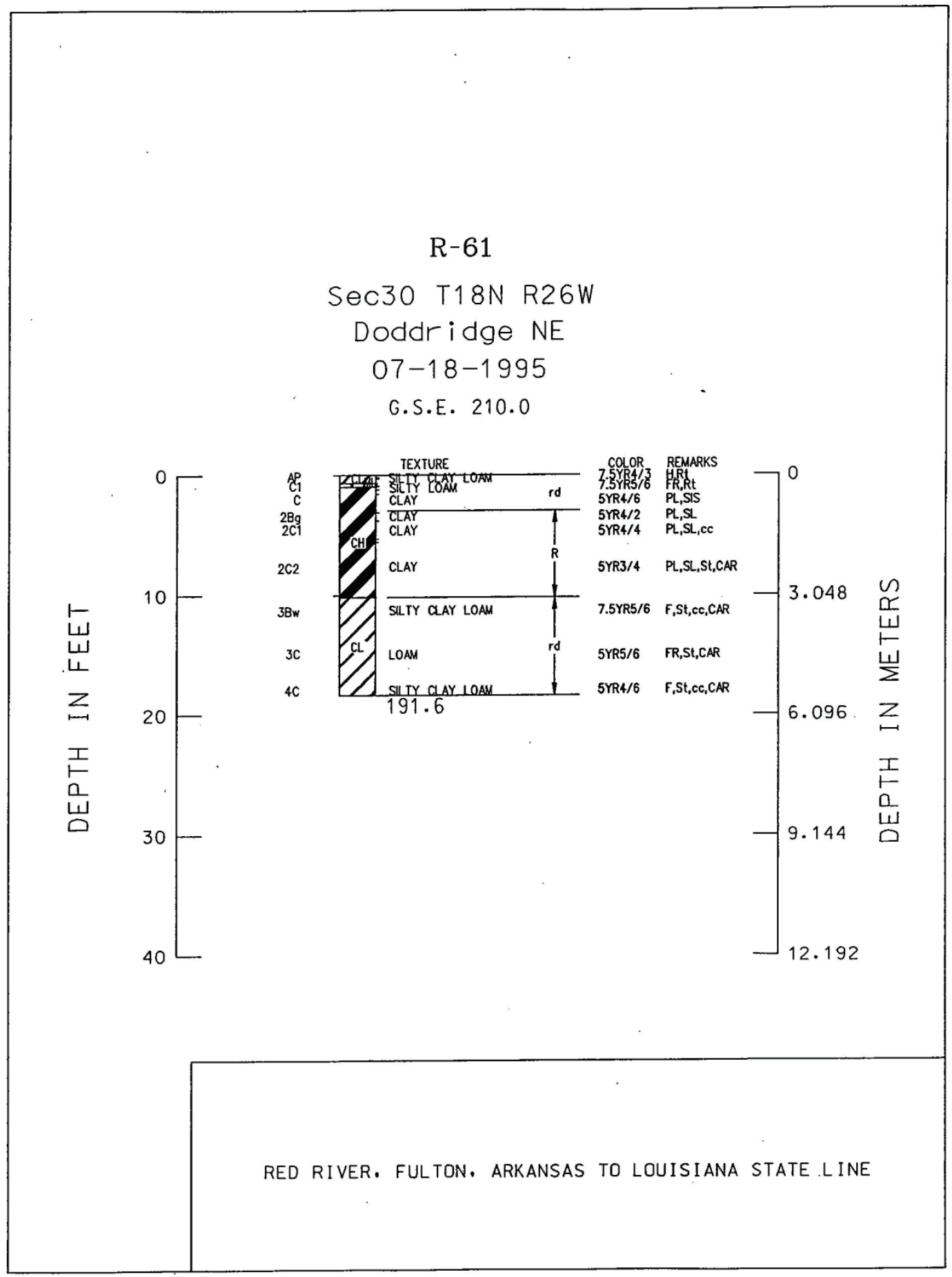




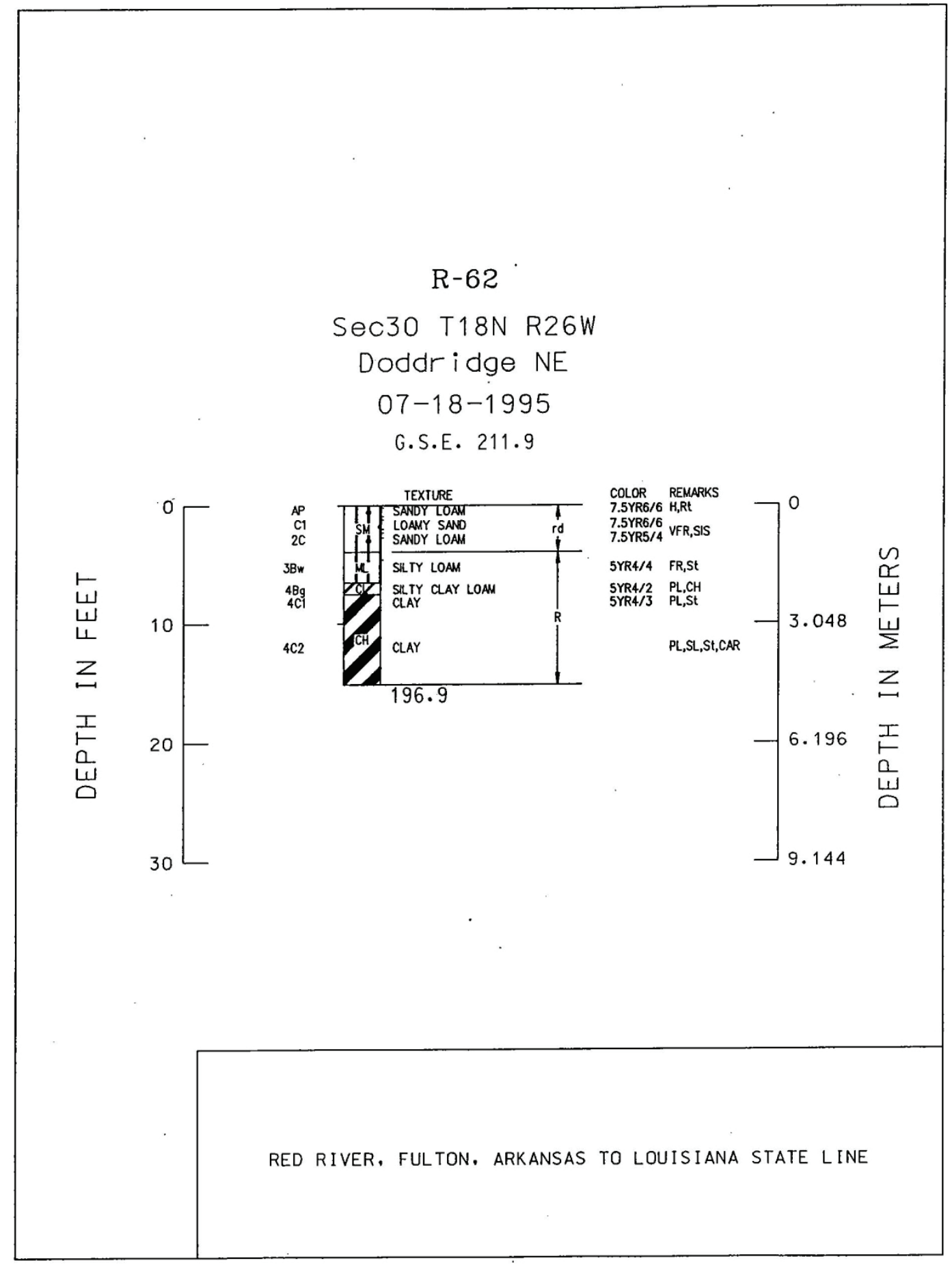




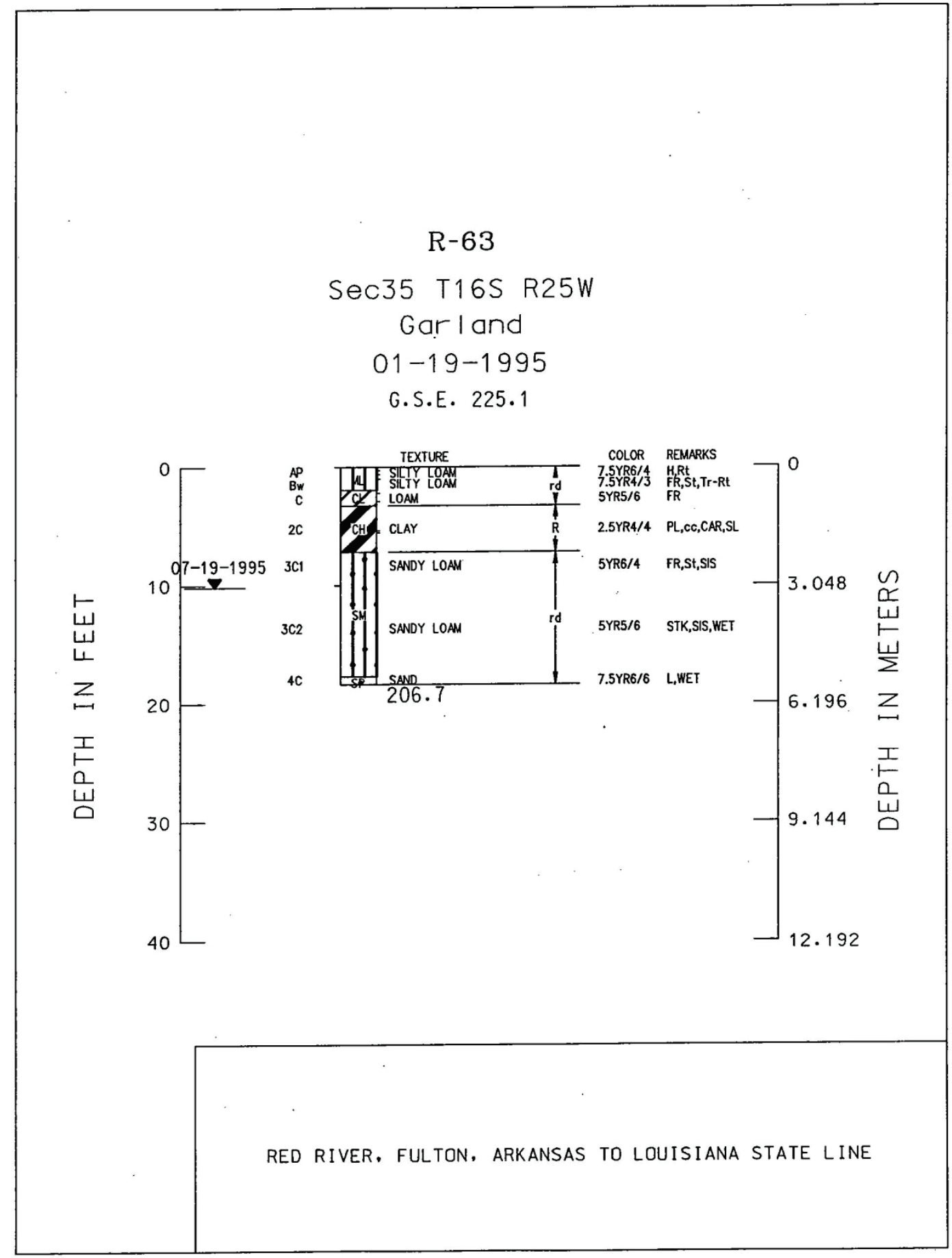




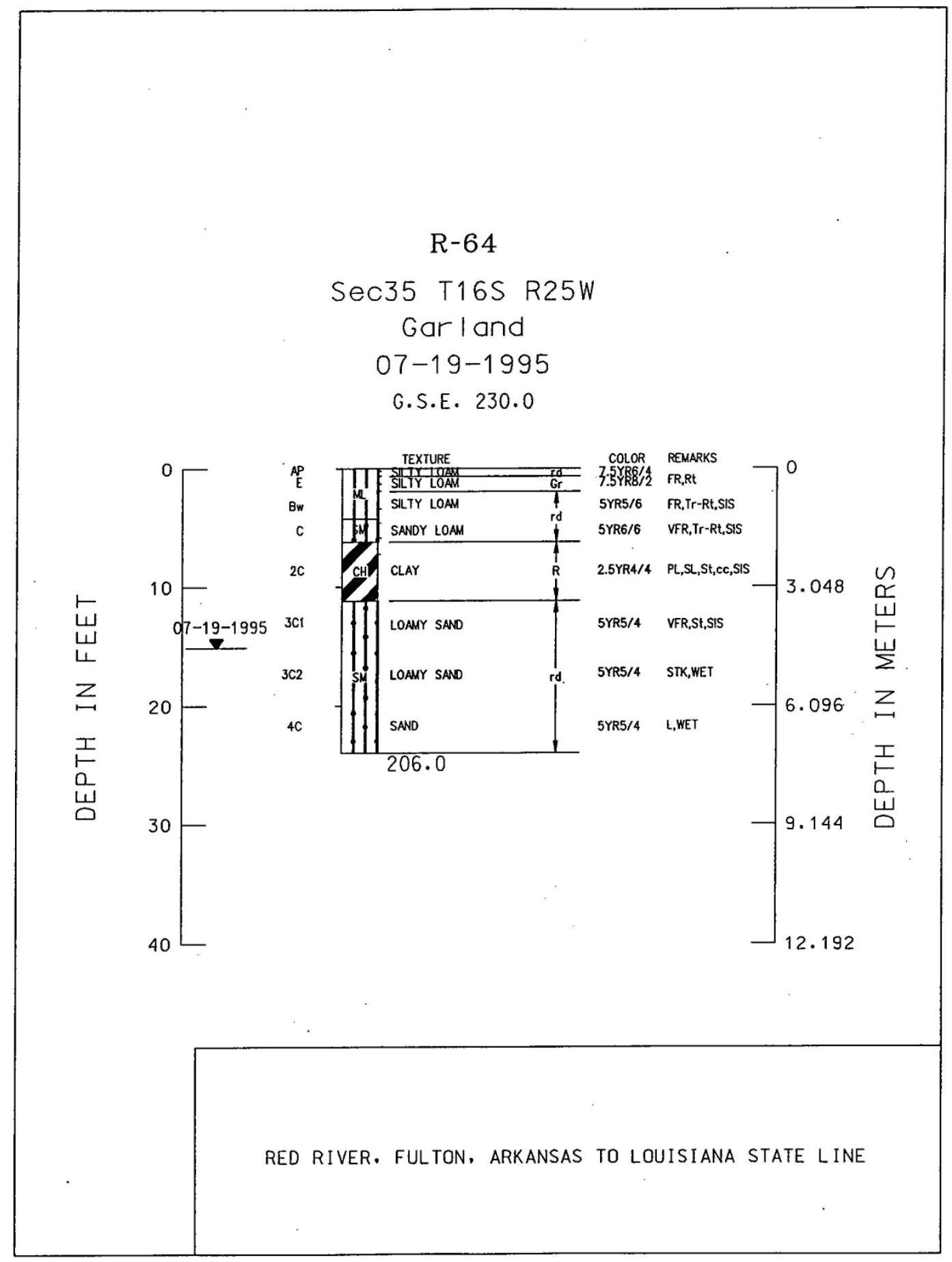




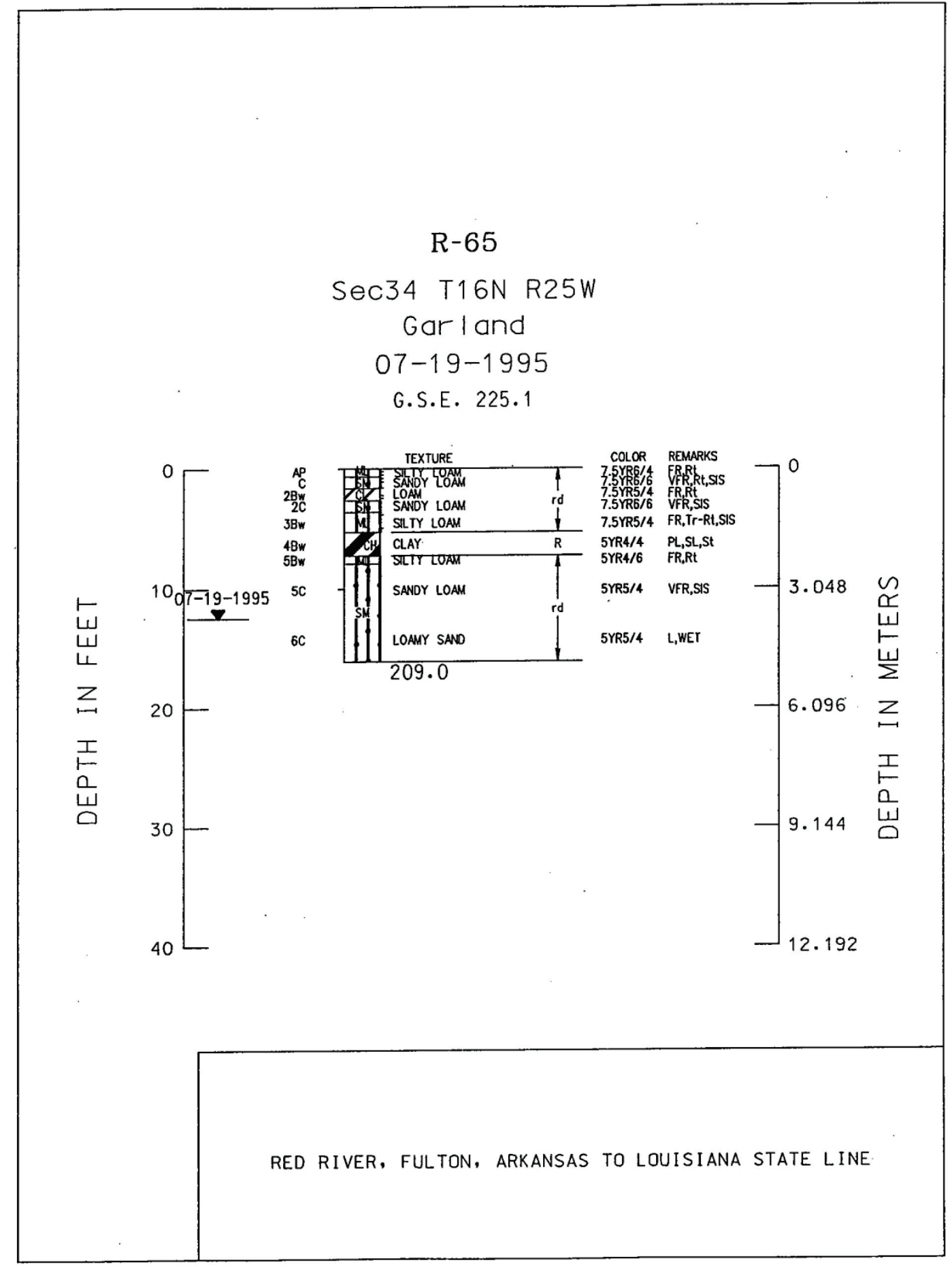




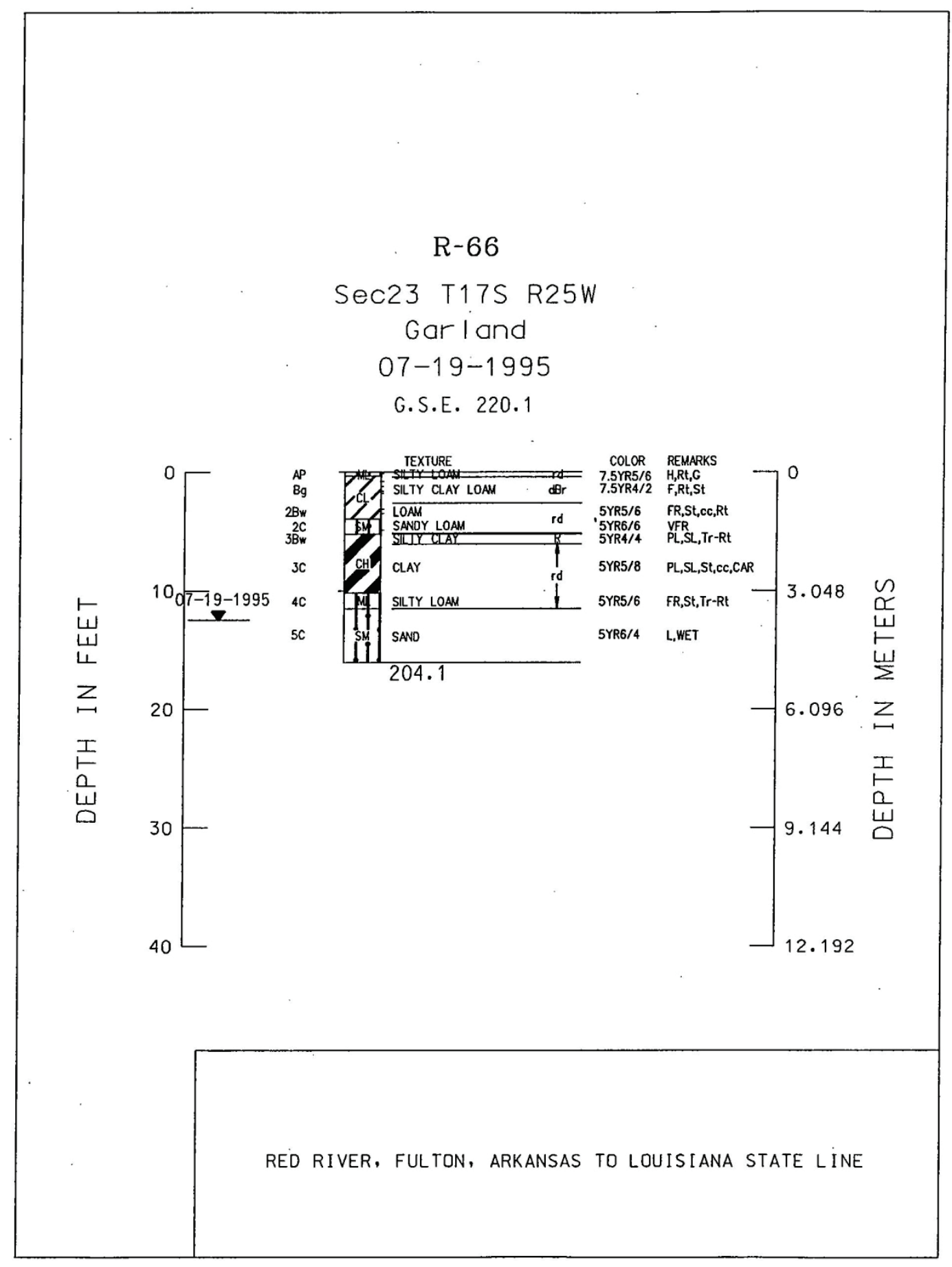




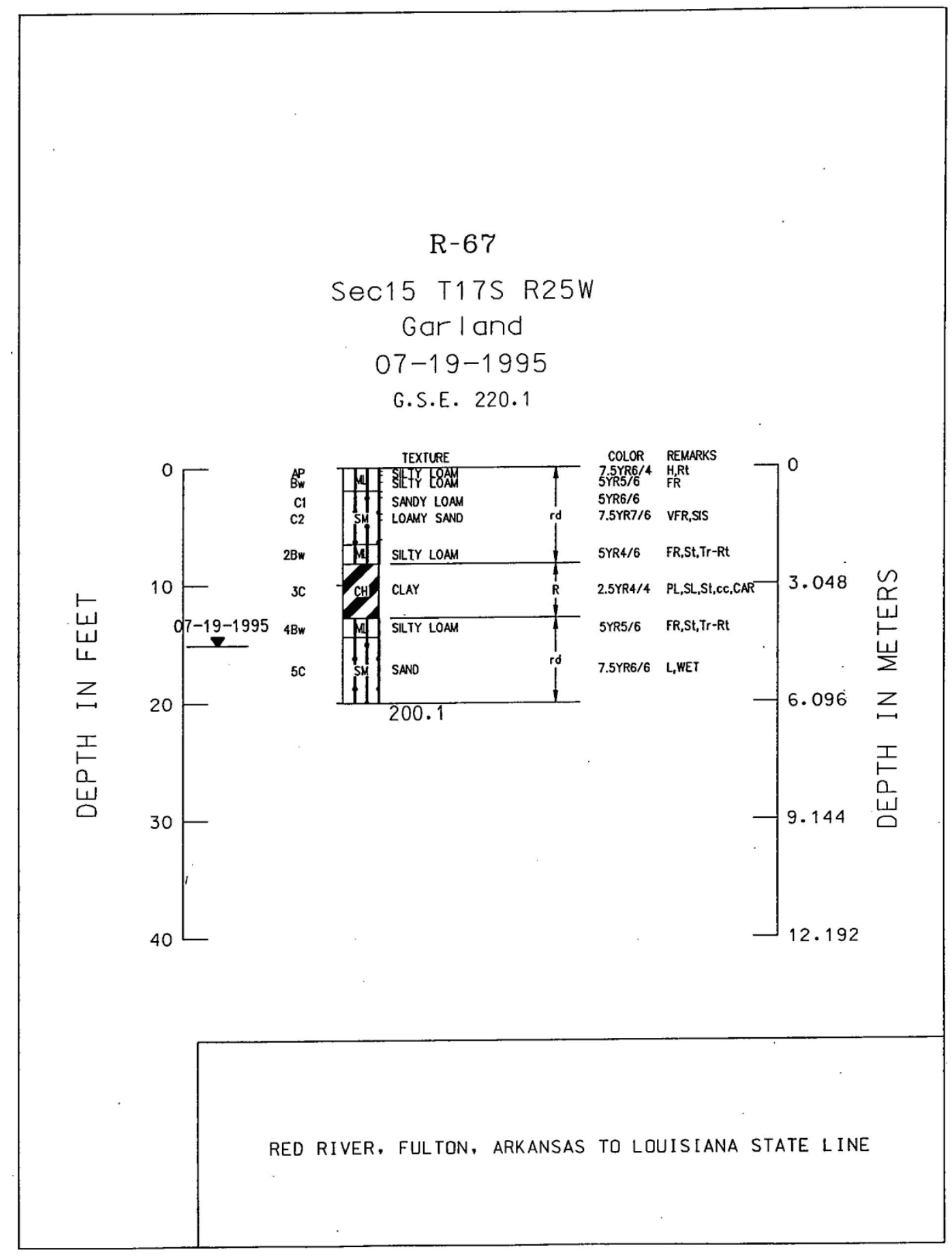




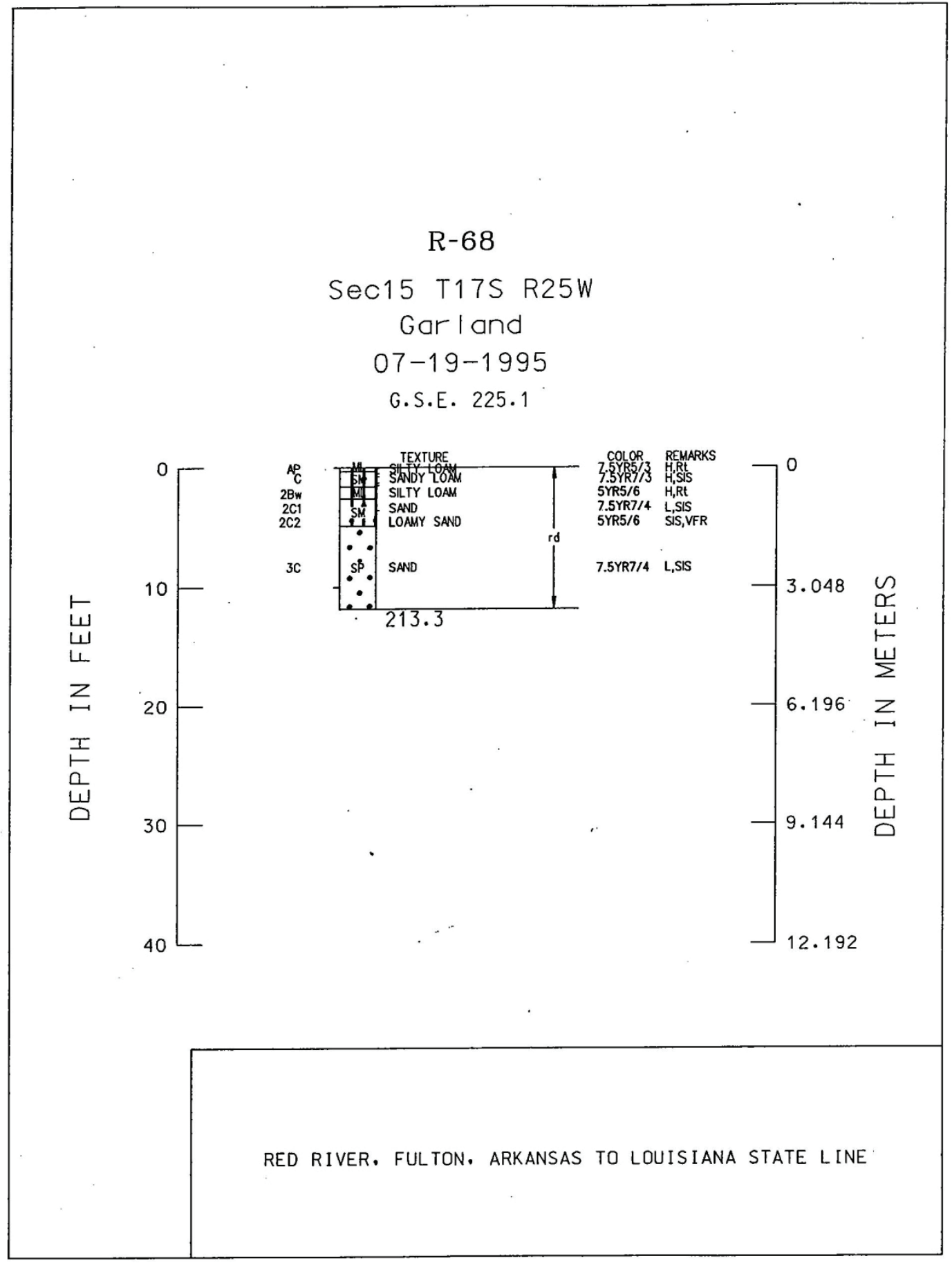




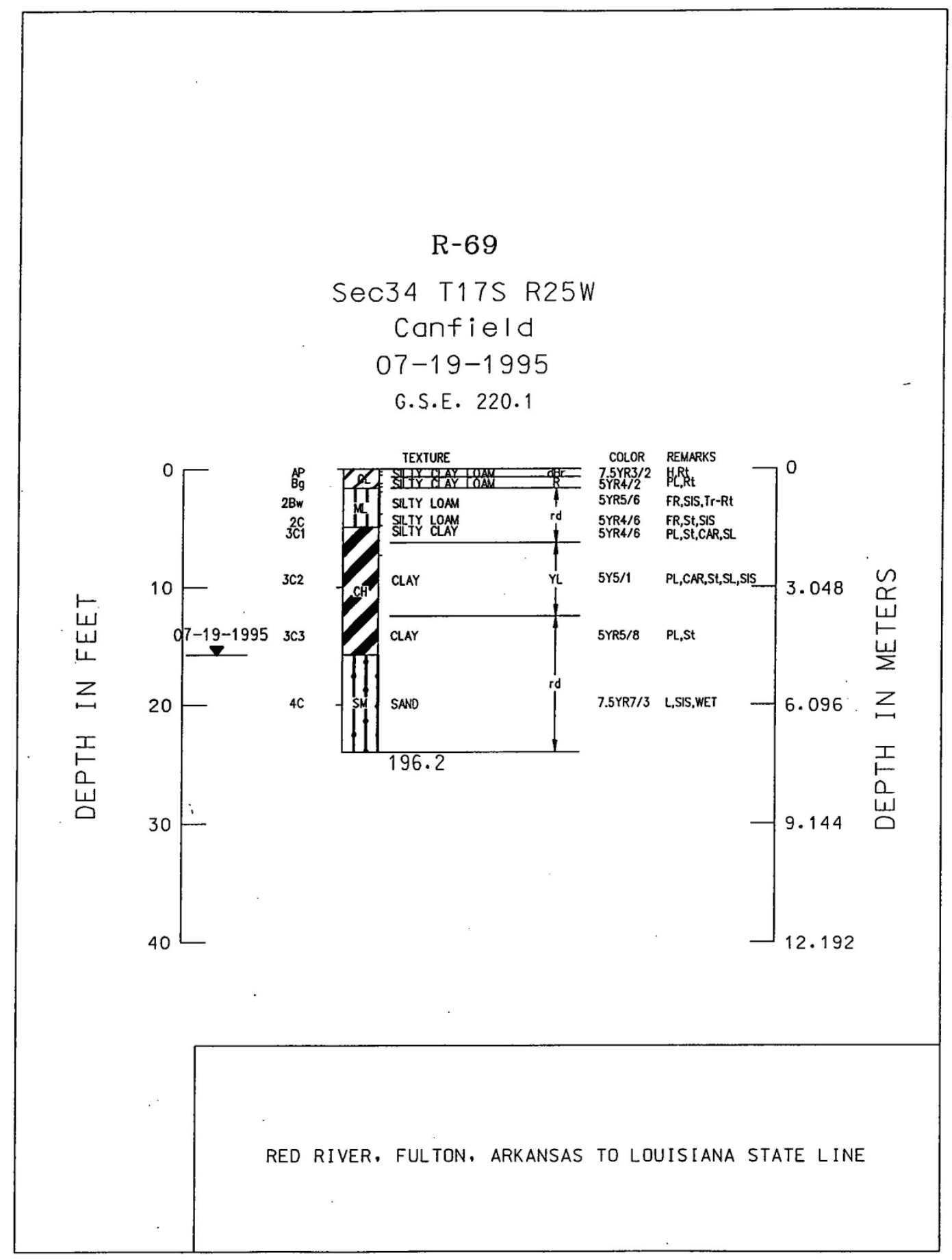




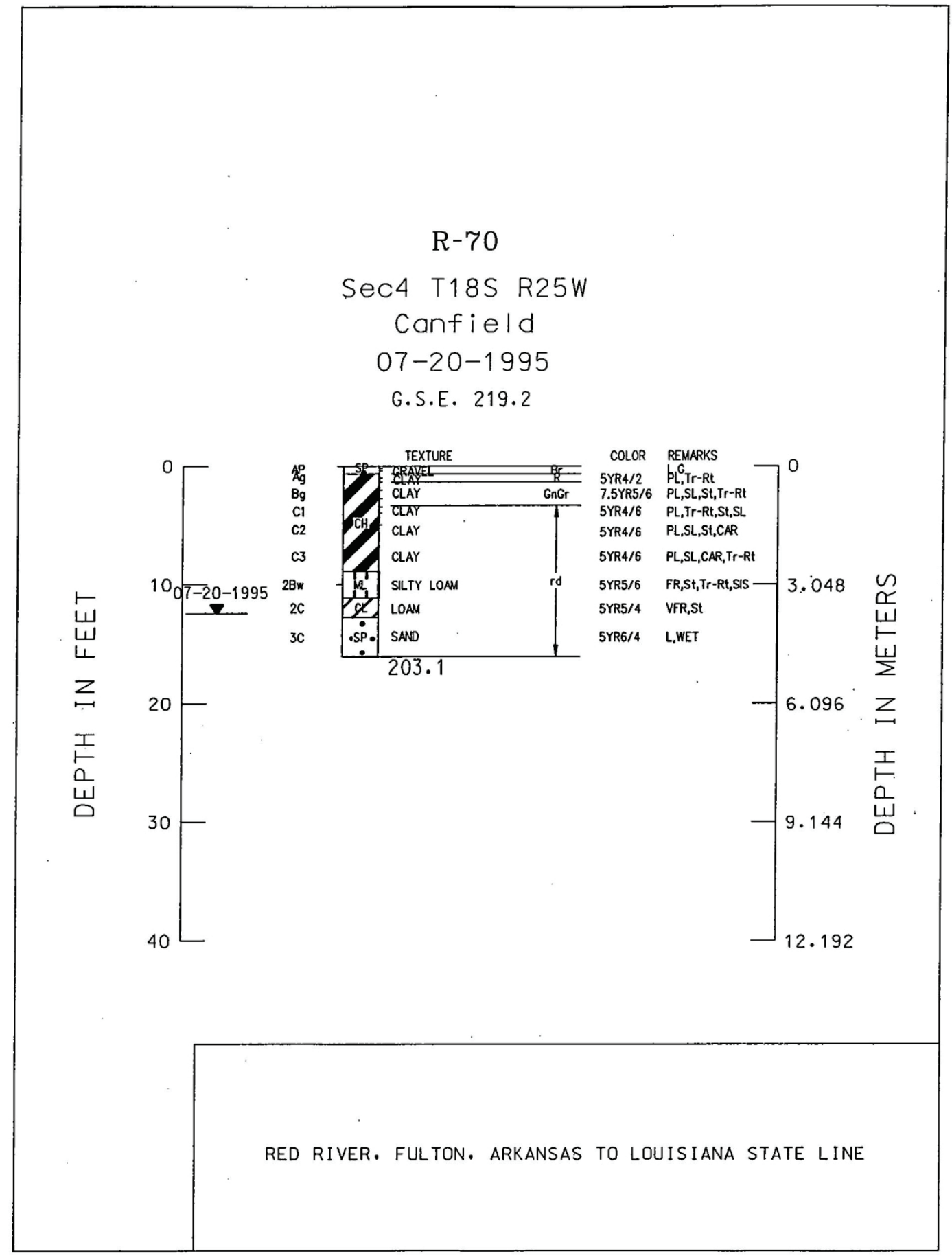




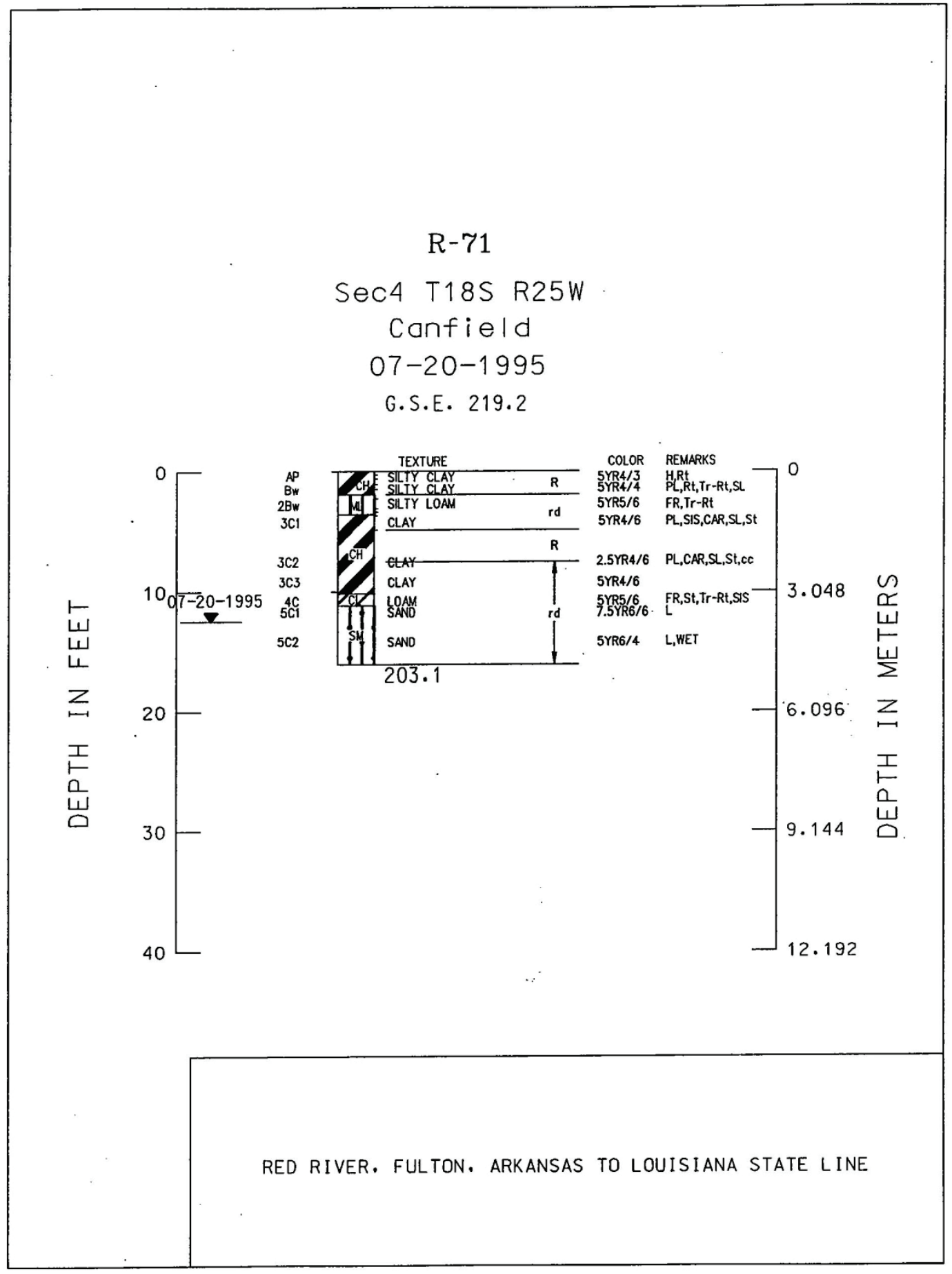




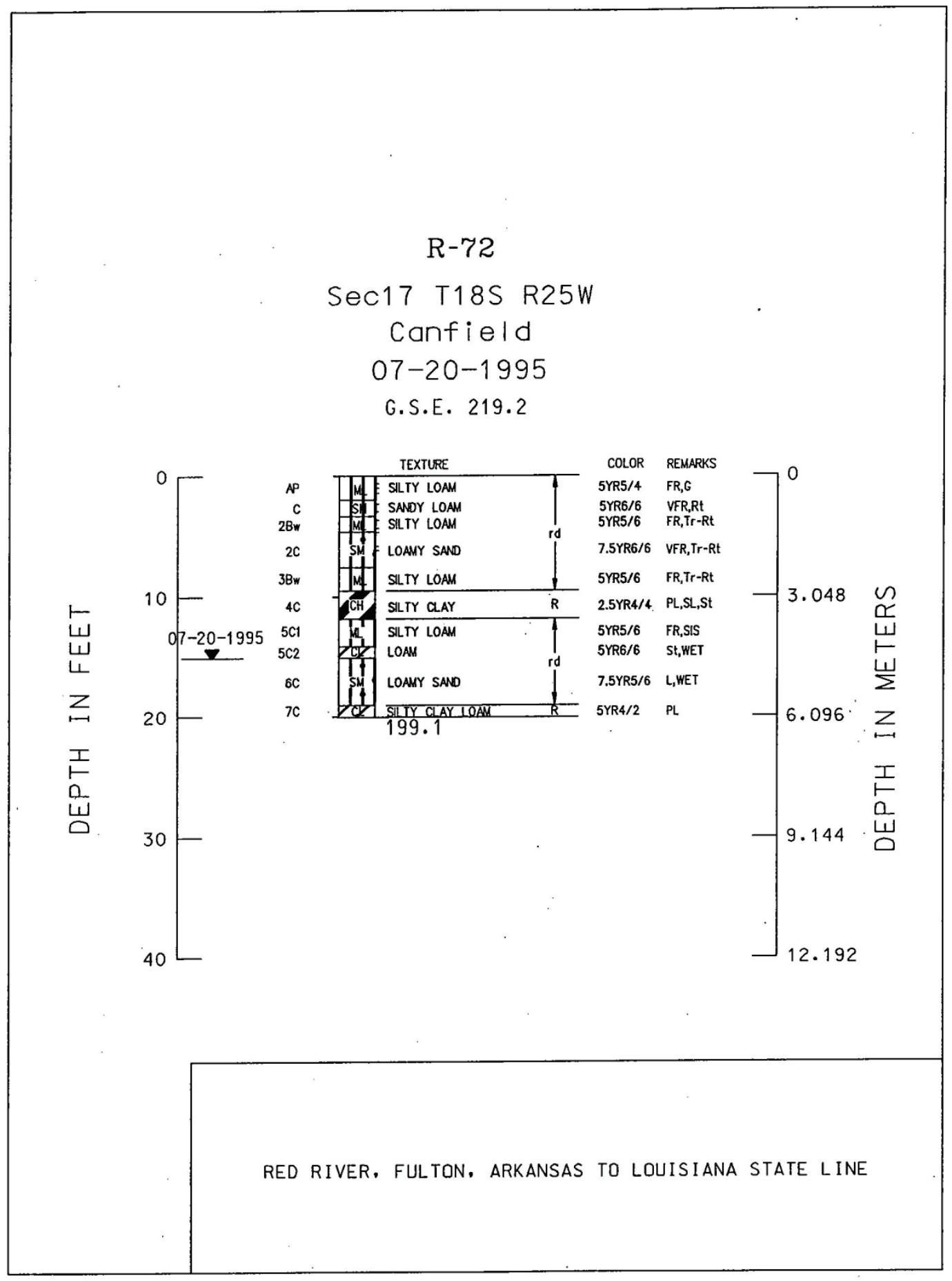




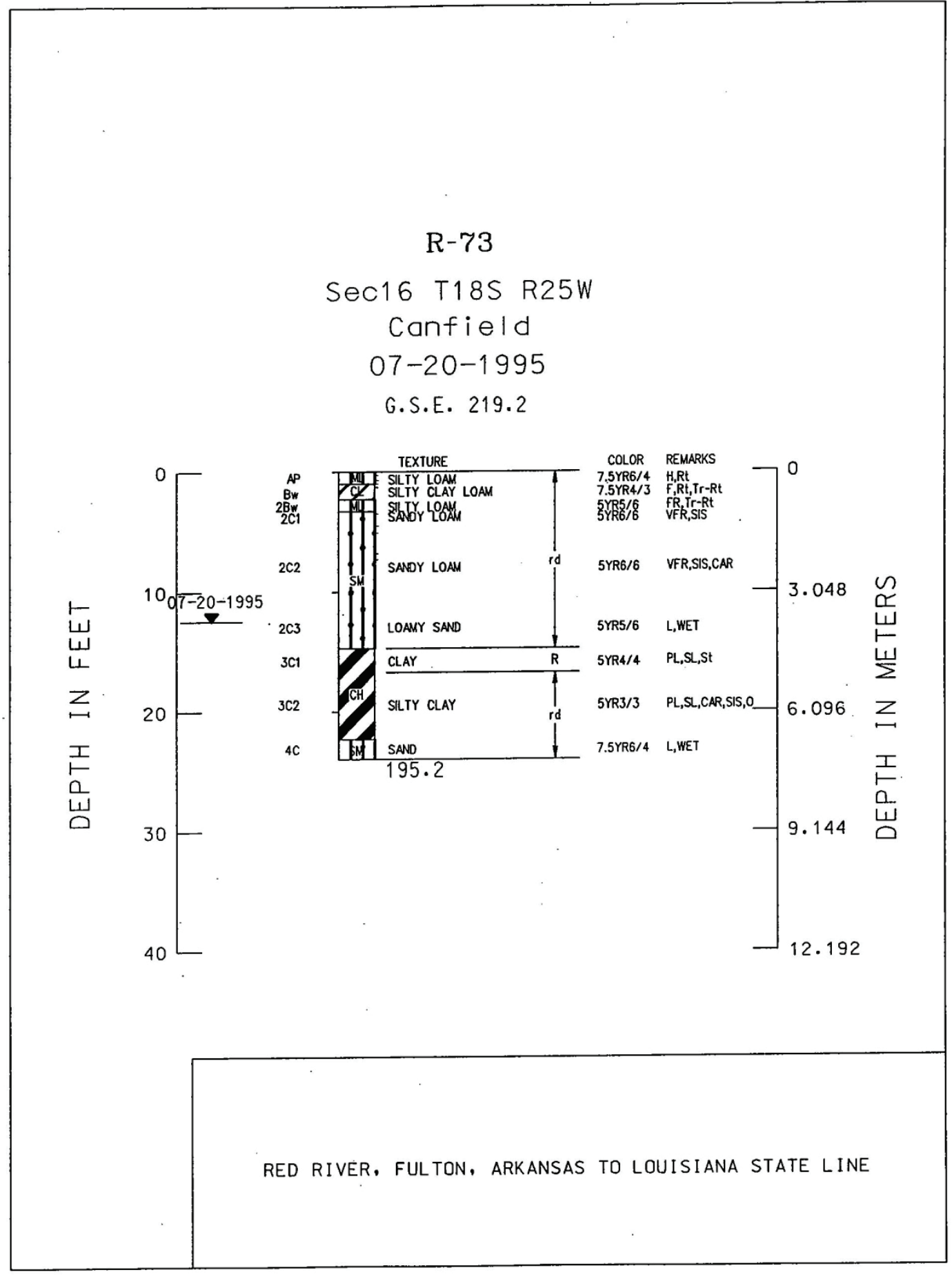




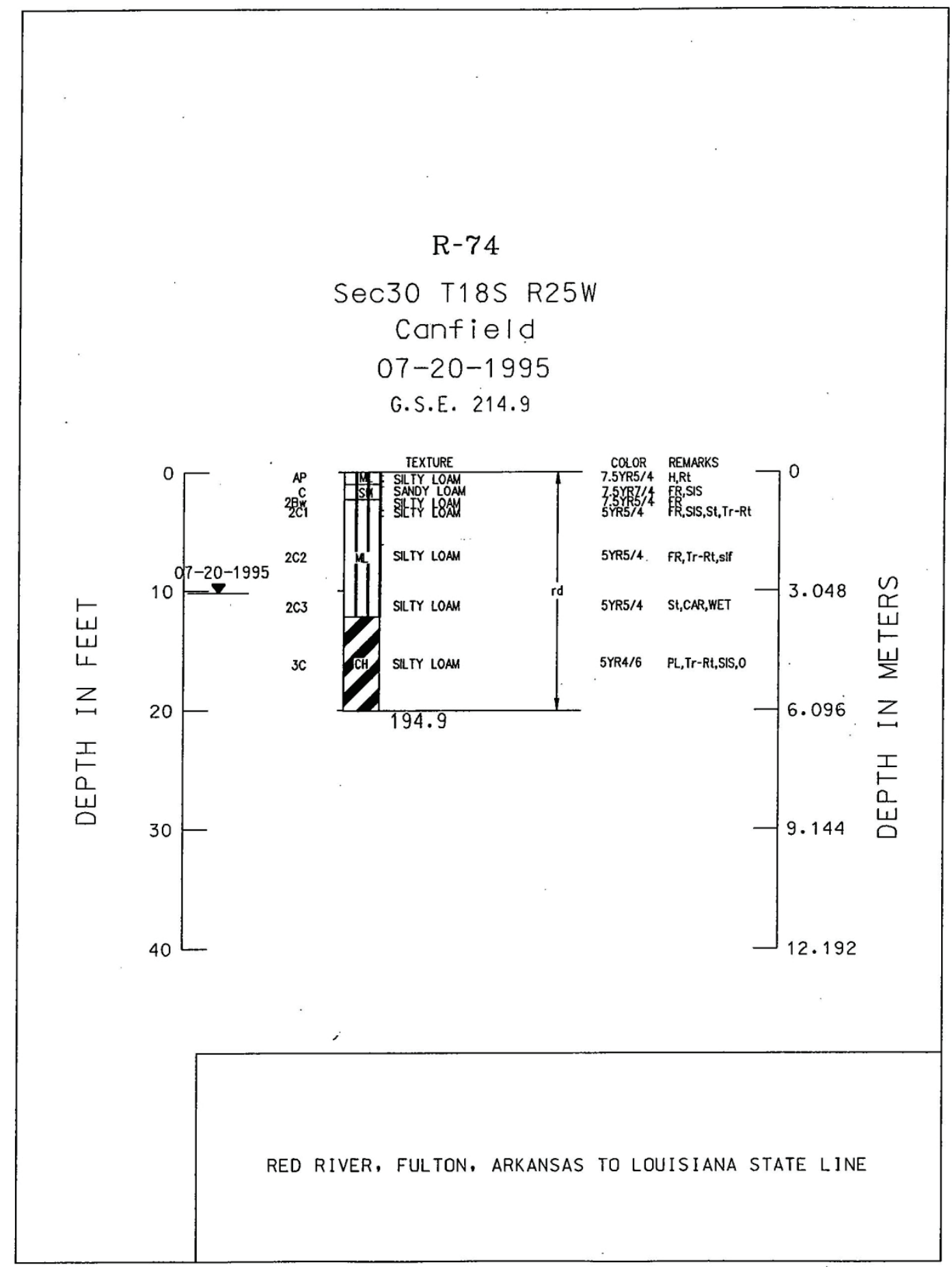




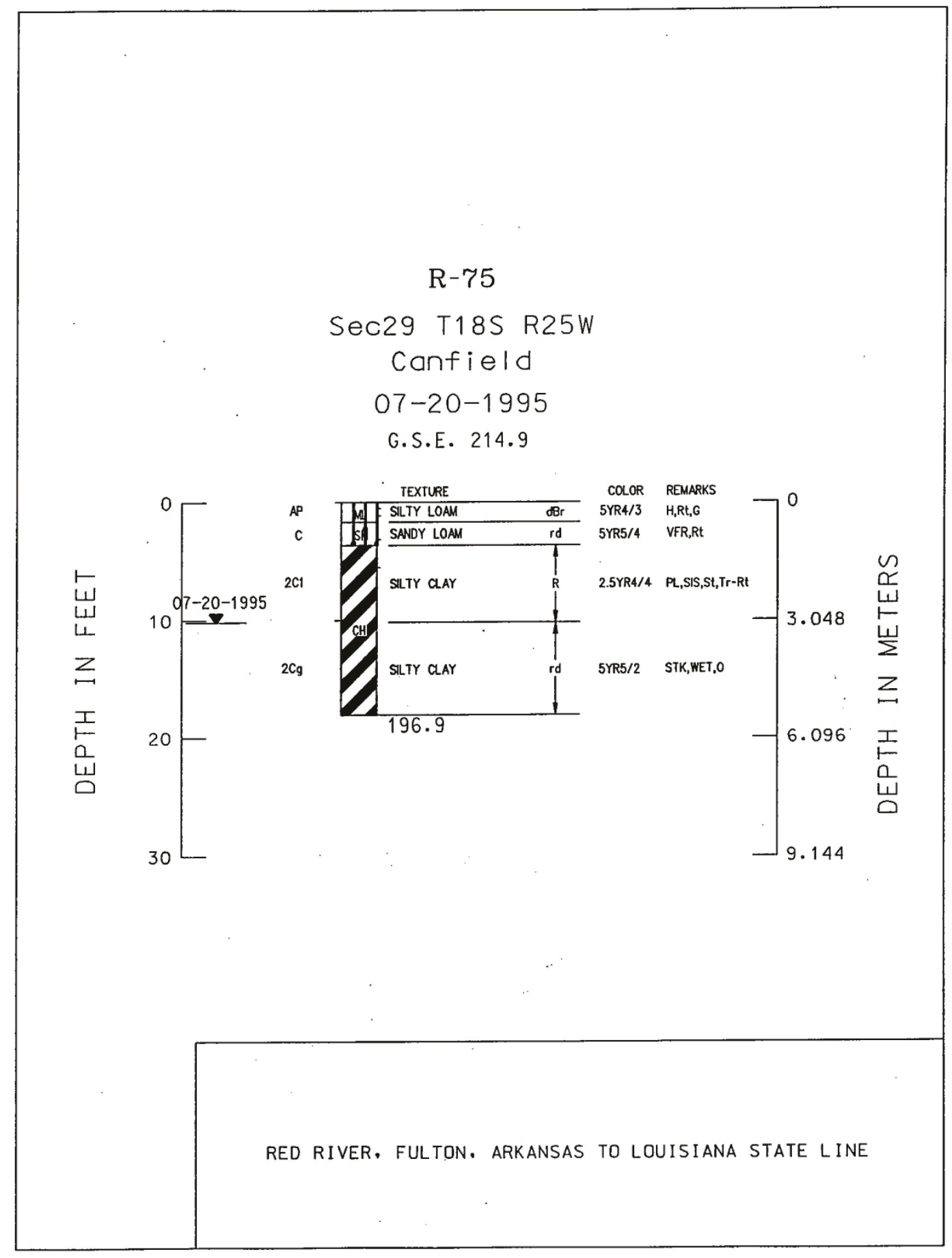




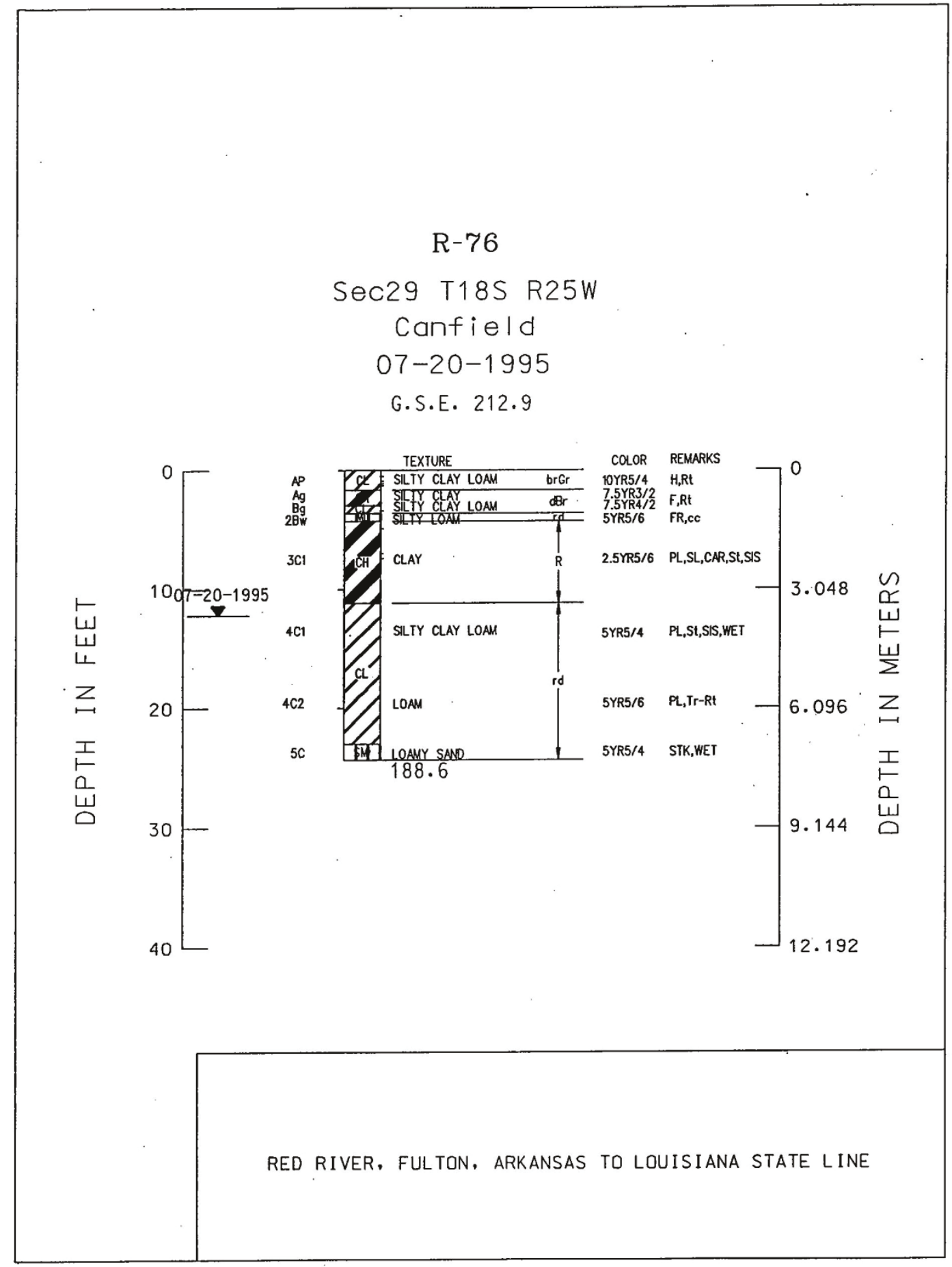




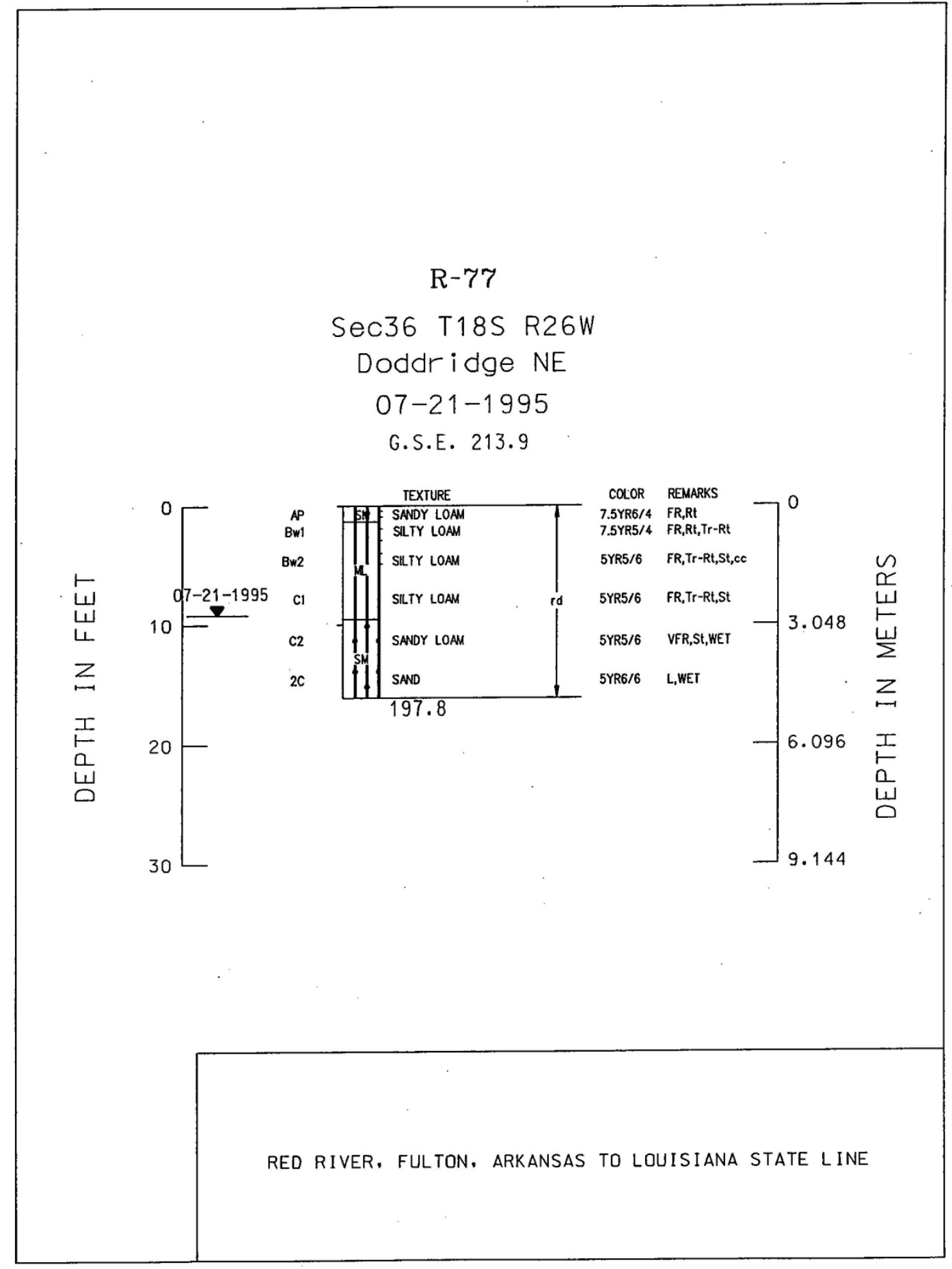




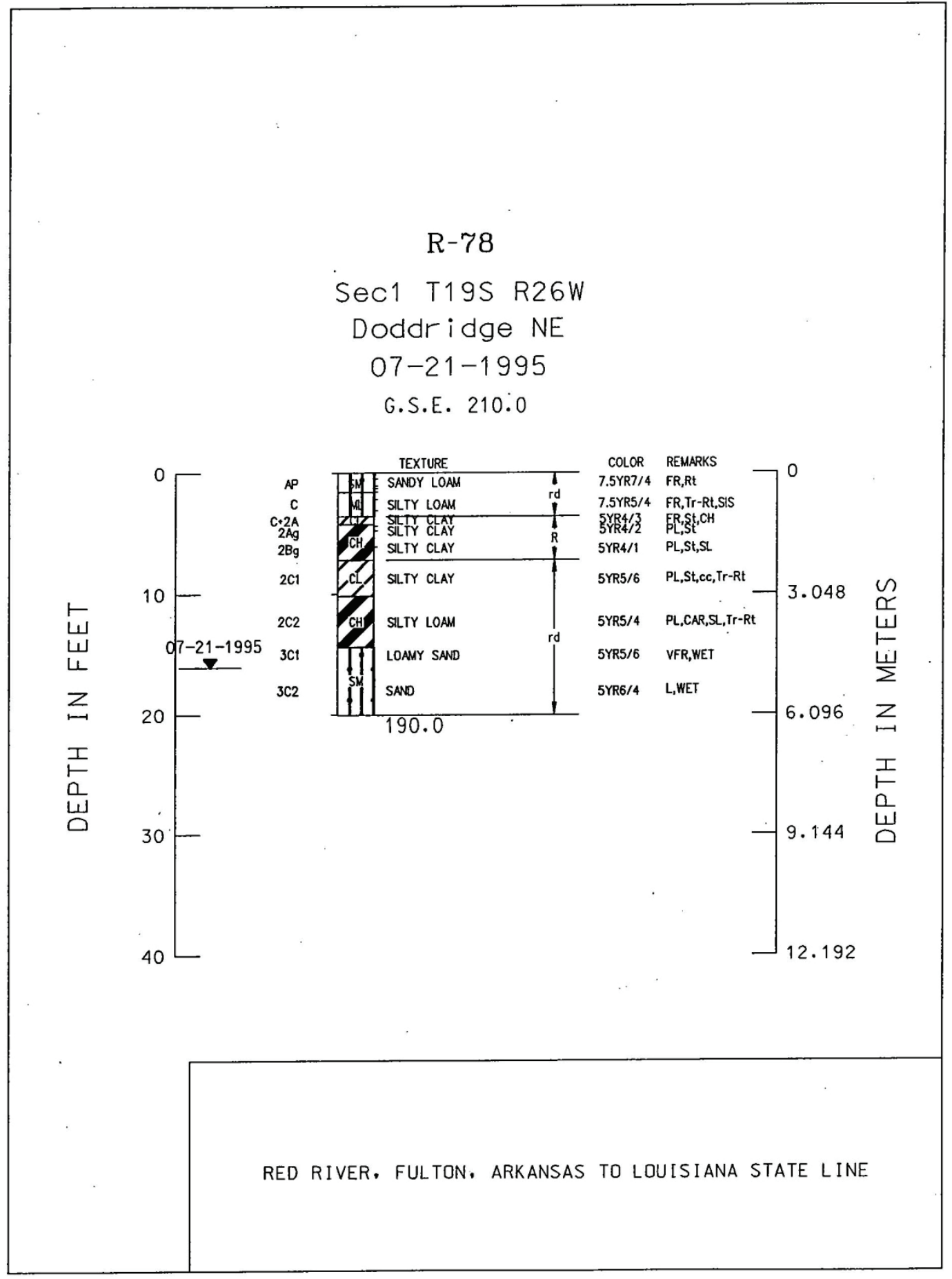




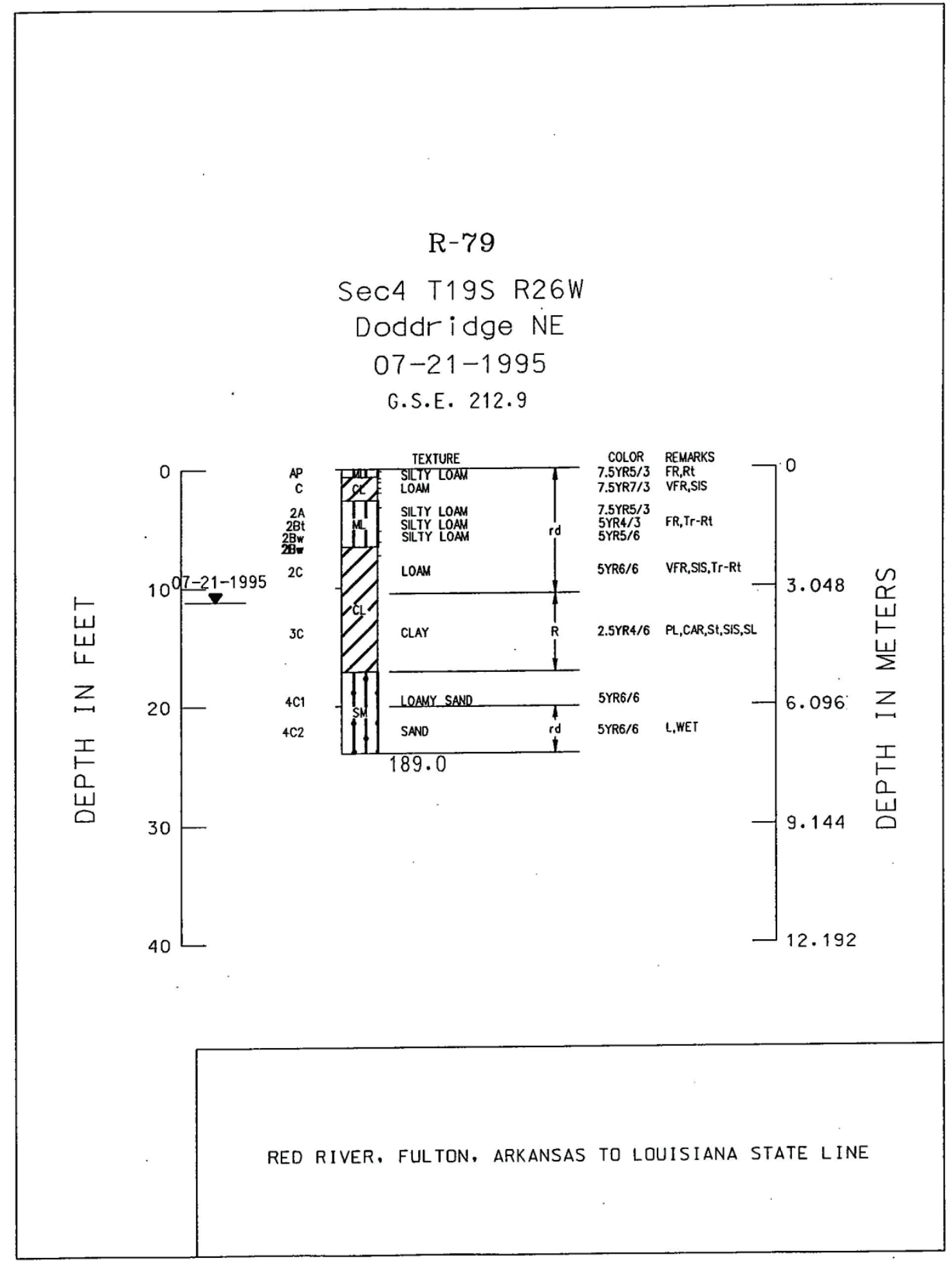




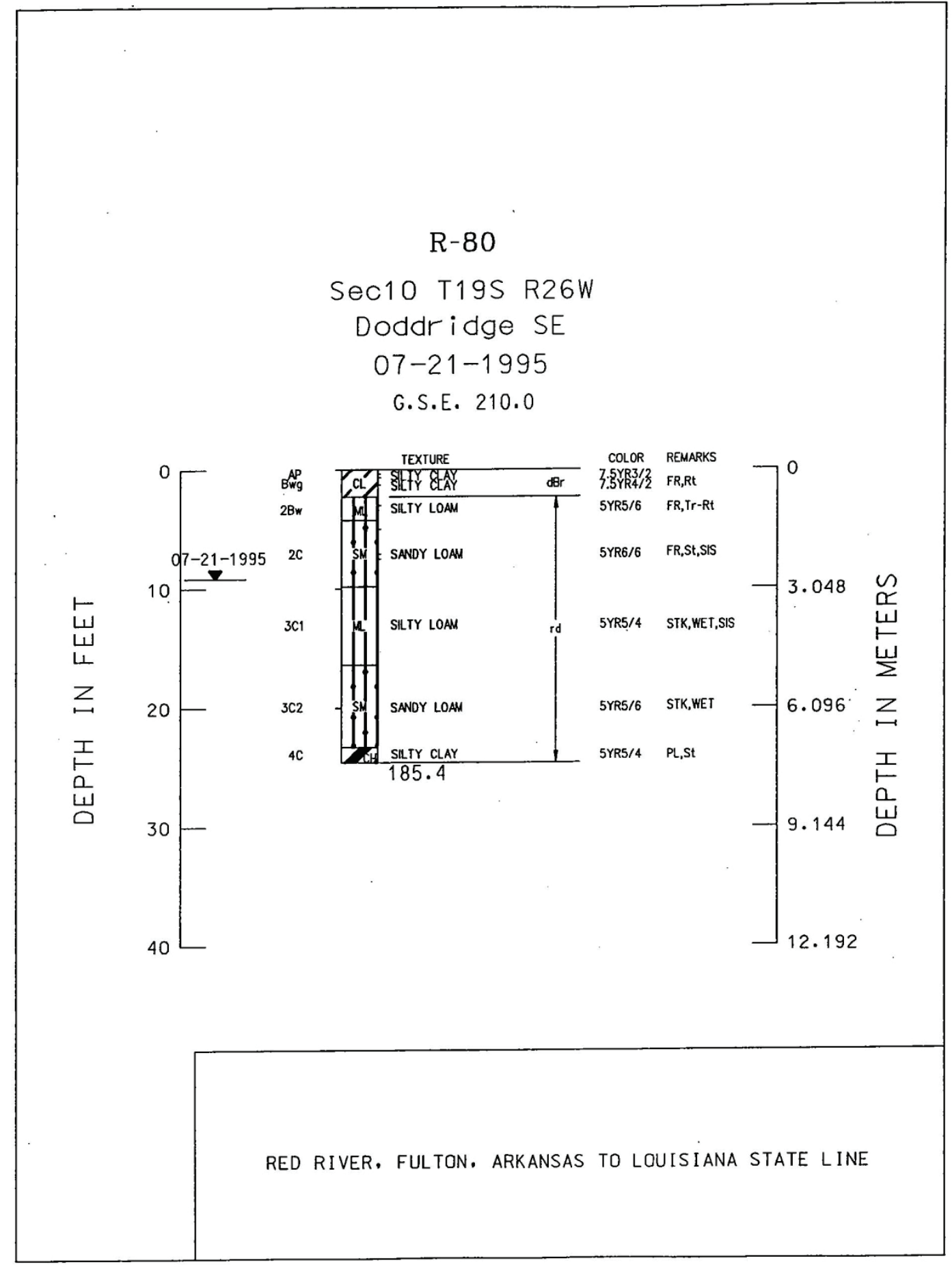




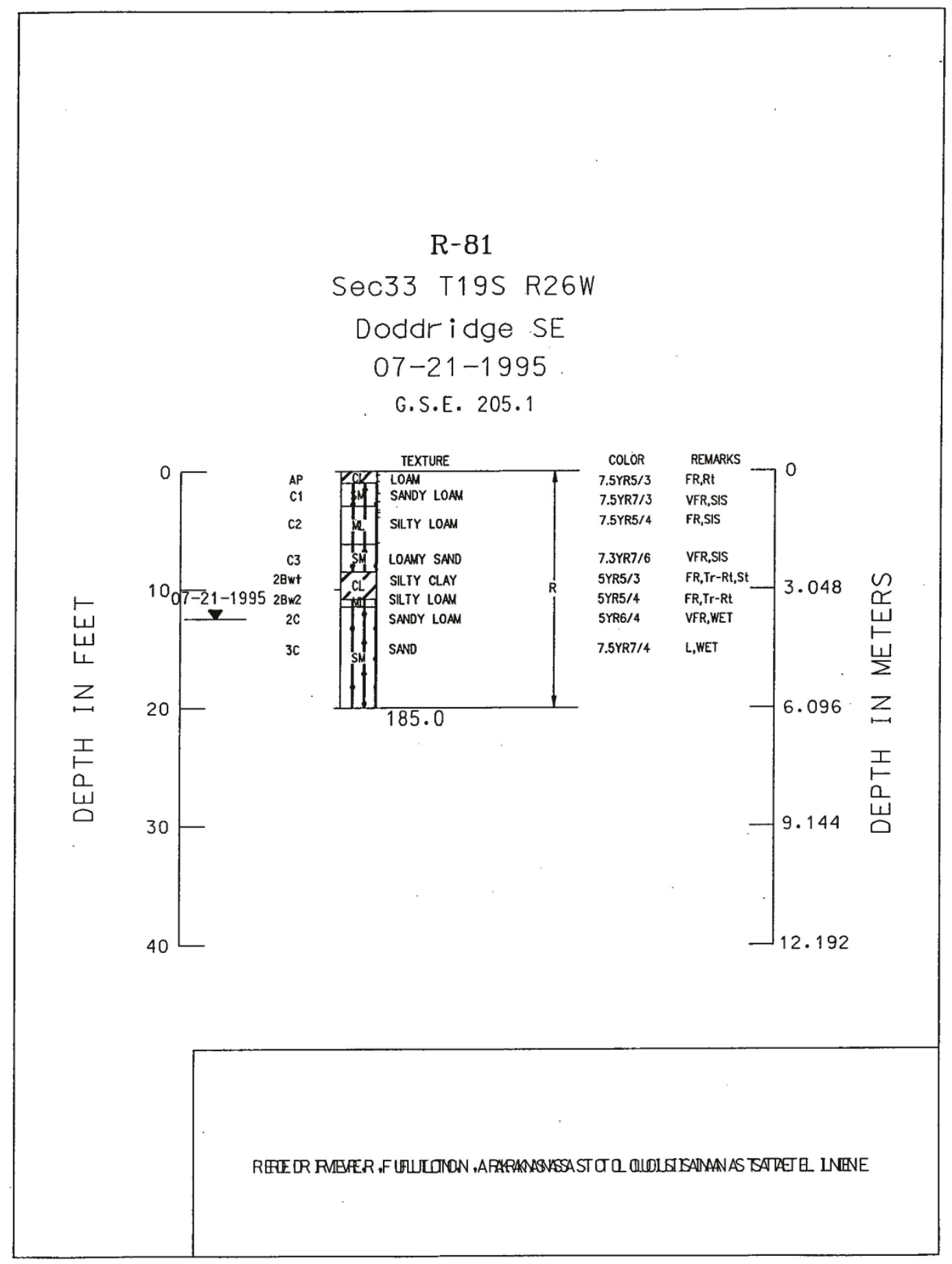




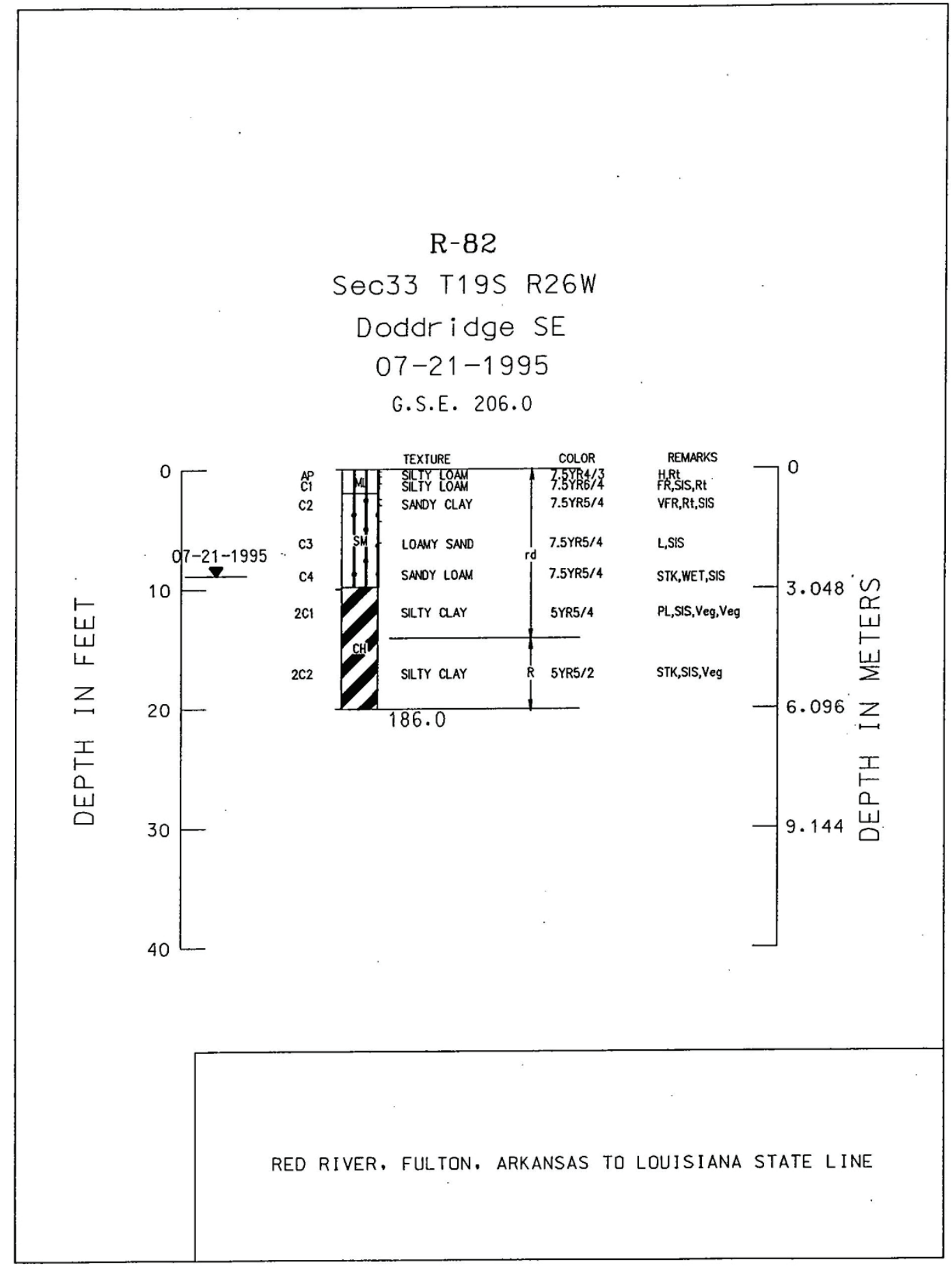




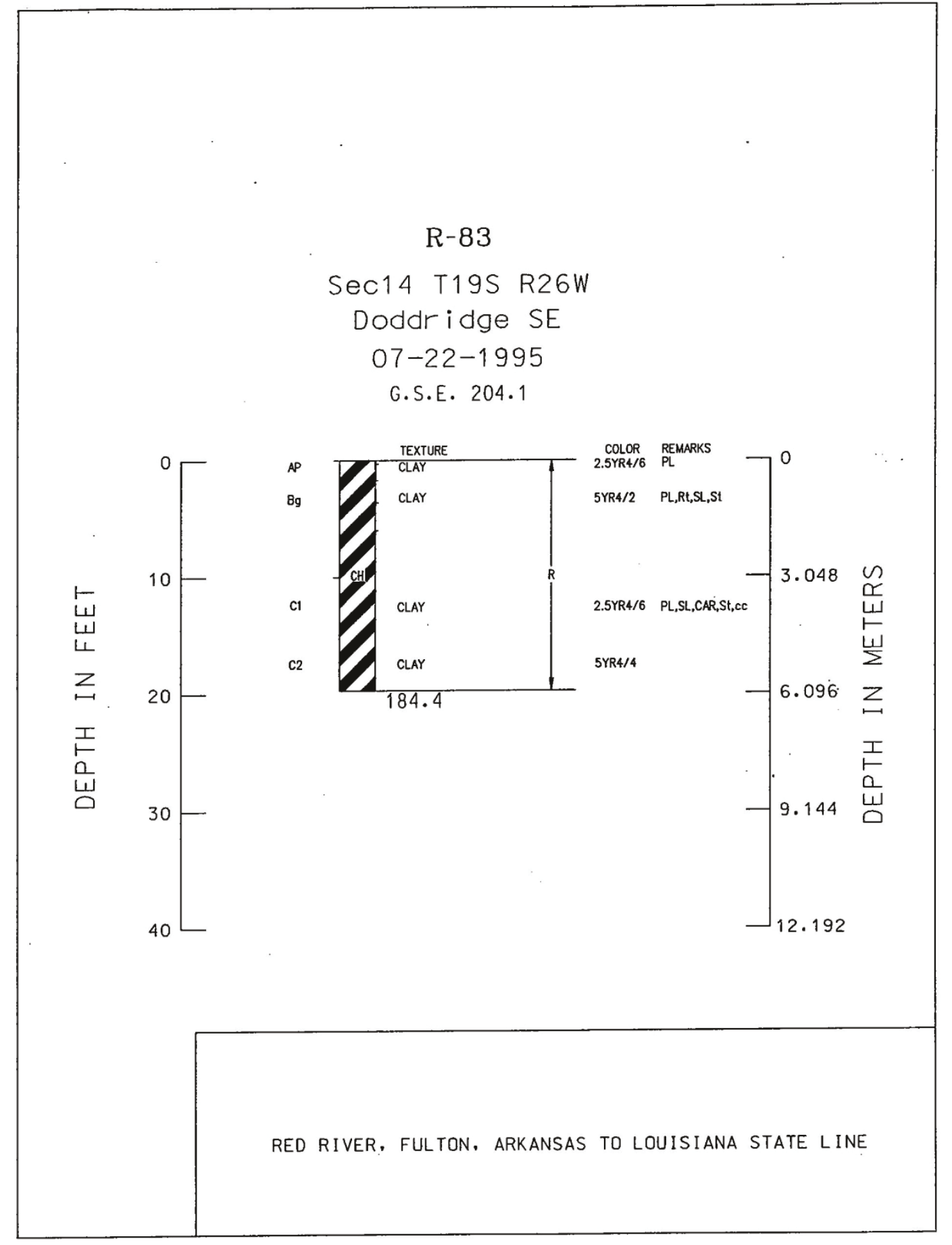




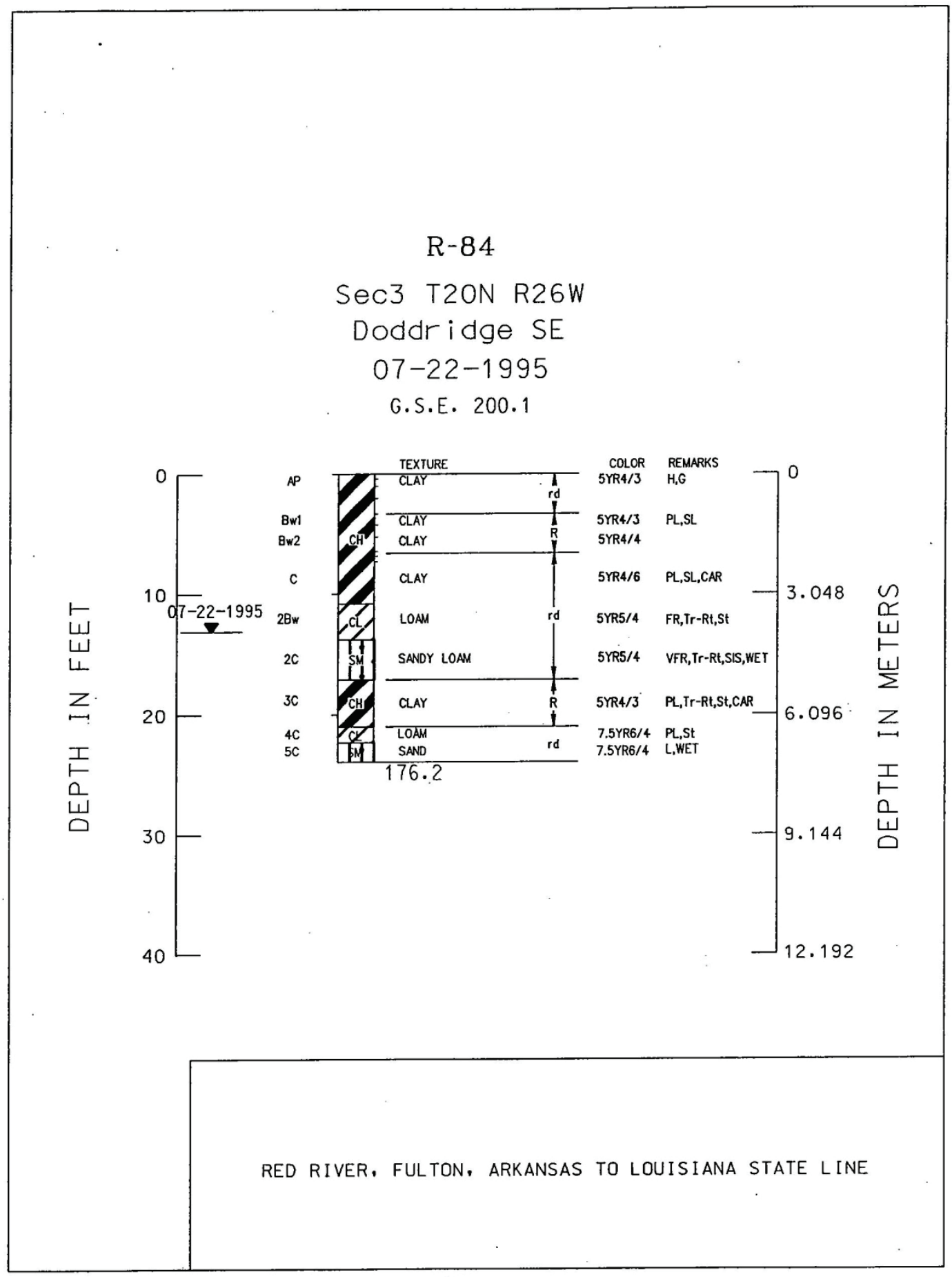




$$
\begin{gathered}
\text { R-85 } \\
\text { Sec2 T18S R18W } \\
\text { Canfield } \\
\text { 07-22-1995 } \\
\text { G.S.E. } 214.9
\end{gathered}
$$
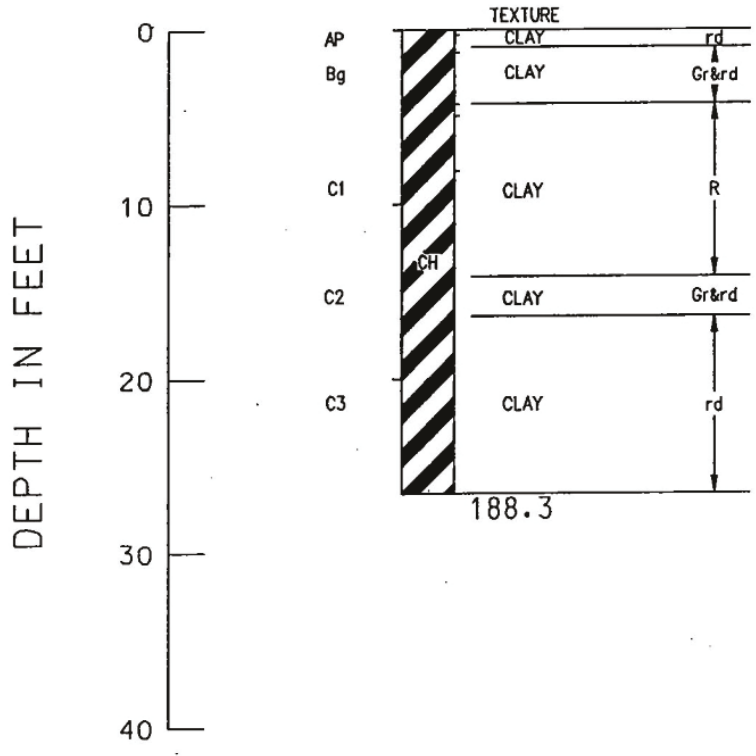

COLOR REMARKS

5YR4/3 REMAK

$5 Y R 4 / 1$ F.SL

188.3

5YR4/4 PL,SL,CAR

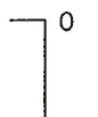

$5 Y 6 / 1 \quad P L$

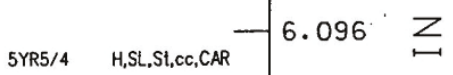

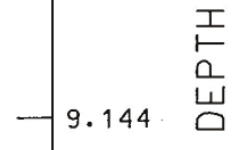

12.192

RED RIVER, FULTON, ARKANSAS TO LOUISIANA STATE LINE 


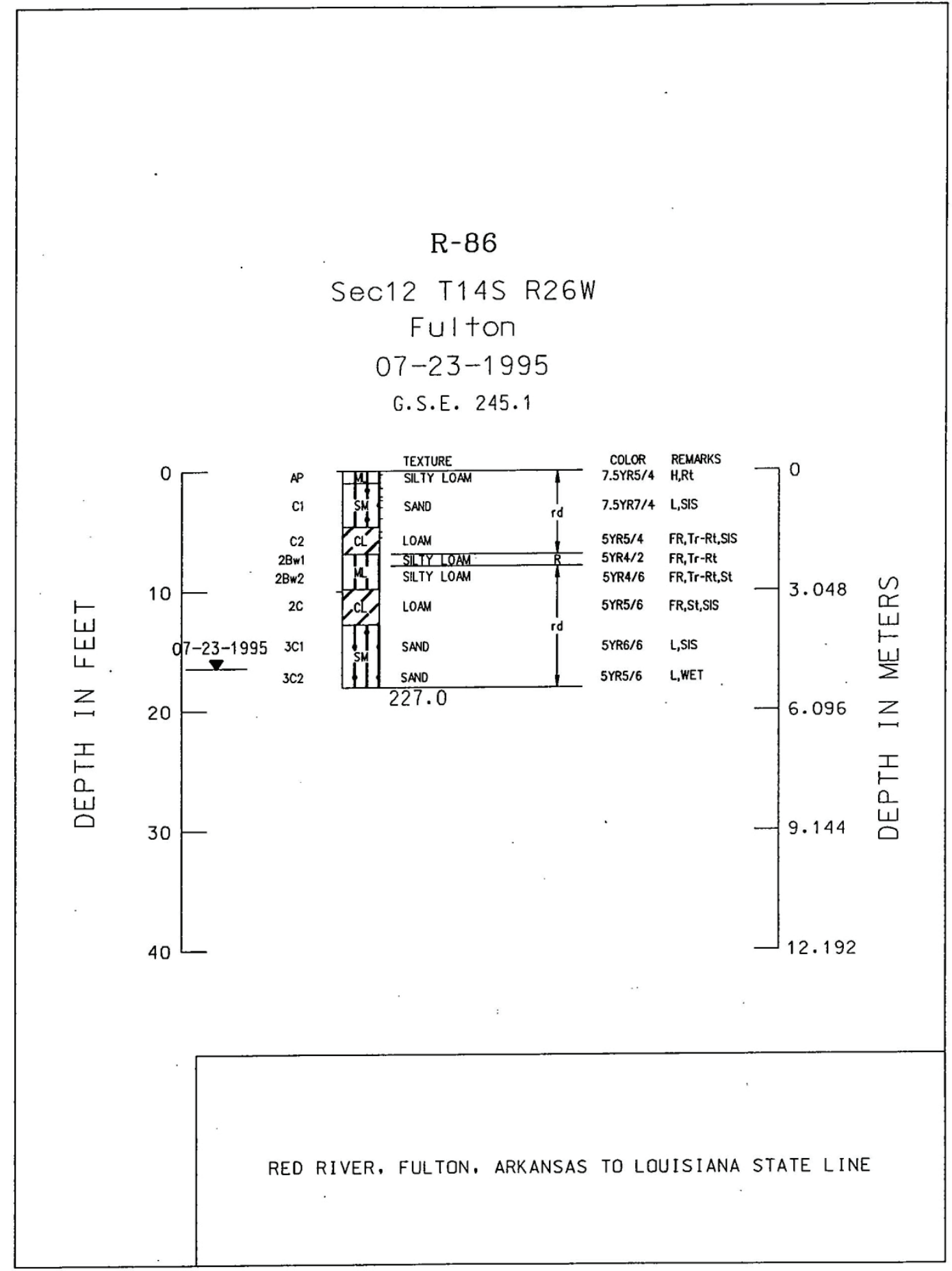




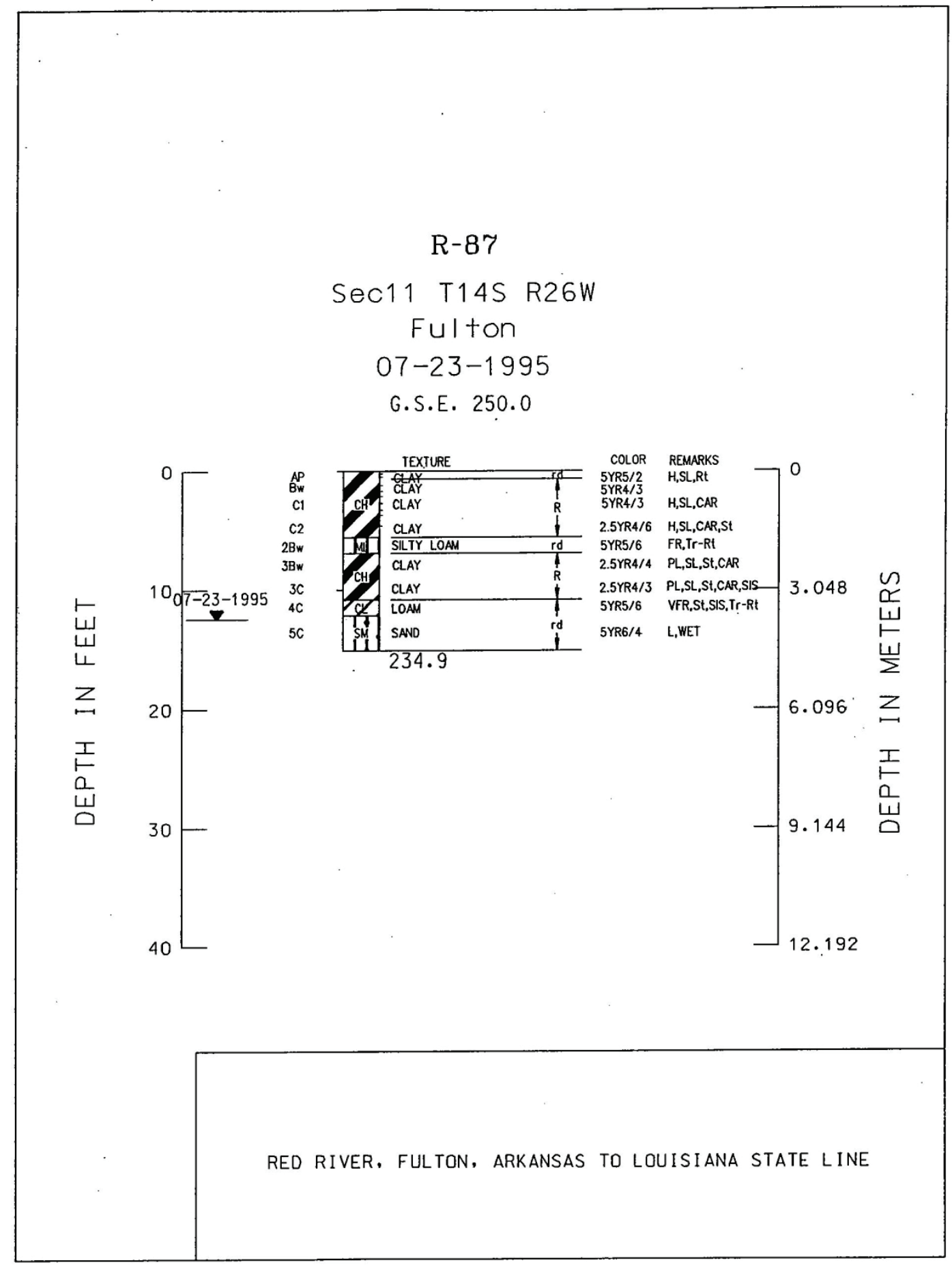




\section{Appendix E: Radiometric Age Dates}




\section{CALIBRATION OF RADIOCARBON AGE TO CALENDAR YEARS}

(Variables:C13/C12=-10.5:lab mult. $=1$ )

Laboratory Number: Beta-90042

Conventional radiocarbon age:

$780+/-60 \mathrm{BP}$

Calibrated results:

(2 sigma, 95\% probability)

cal AD 1170 to 1300

Intercept data: Intercept of radiocarbon age
with calibration curve:

cal AD 1265

1 sigma calibrated results: (68\% probability)

cal $\mathrm{AD} 1220$ to 1285

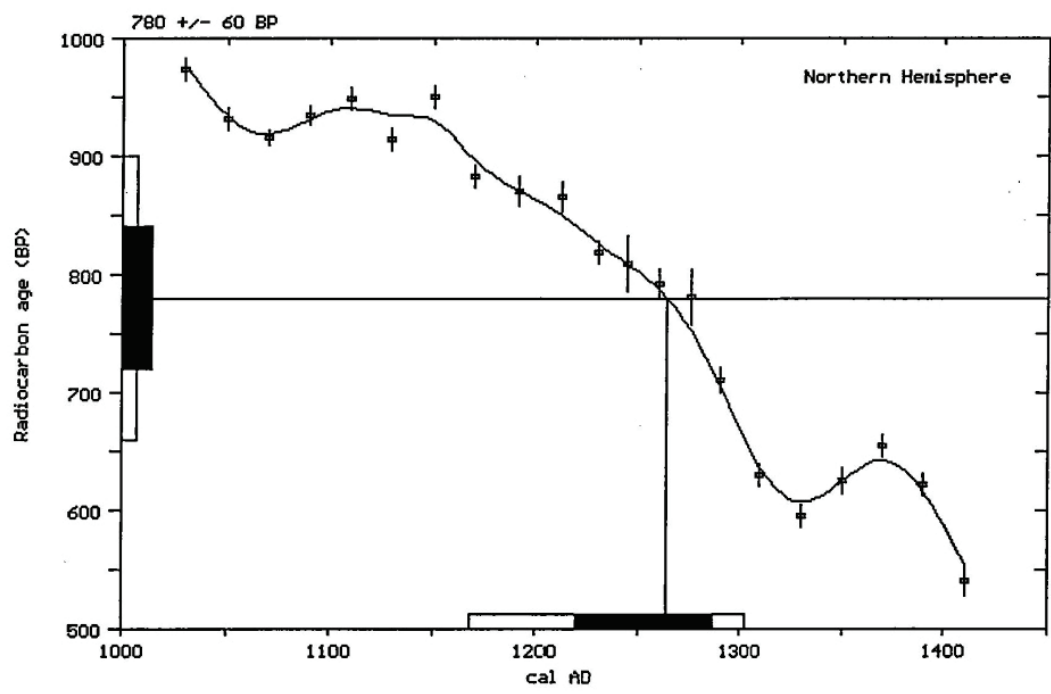

References:

Pretoria Calibration Curve for Short Lived Samples

Vogel, J. C., Fuls, A., Visser, E. and Becker, B., 1993, Radiocarbon 35(1), p73-86

A Simplified Approach to Calibrating C14 Dates

Talma, A. S. and Vogel, J. C., 1993, Radiocarbon 35(2), p317-322

Calibration - 1993

Stuiver, M., Long, A., Kra, R. S. and Devine, J. M., 1993, Radiocarbon 35(I) 
CALIBRATION OF RADIOCARBON AGE TO CALENDAR YEARS

(Variables:C13/C12=-24.9:lab mult. $=1$ )

Laboratory Number: Beta-90043

Conventional radiocarbon age: $\quad 4520+/-60 \mathrm{BP}$

Calibrated results: $\quad$ cal BC 3365 to 3025 and

(2 sigma, 95\% probability) cal BC 2970 to 2940

Intercept data:

Intercepts of radiocarbon age with calibration curve:

cal BC 3320 and cal BC 3220 and cal BC 3180 and cal BC 3165 and cal BC 3130

1 sigma calibrated results: $\quad$ cal BC 3350 to 3090 (68\% probability)

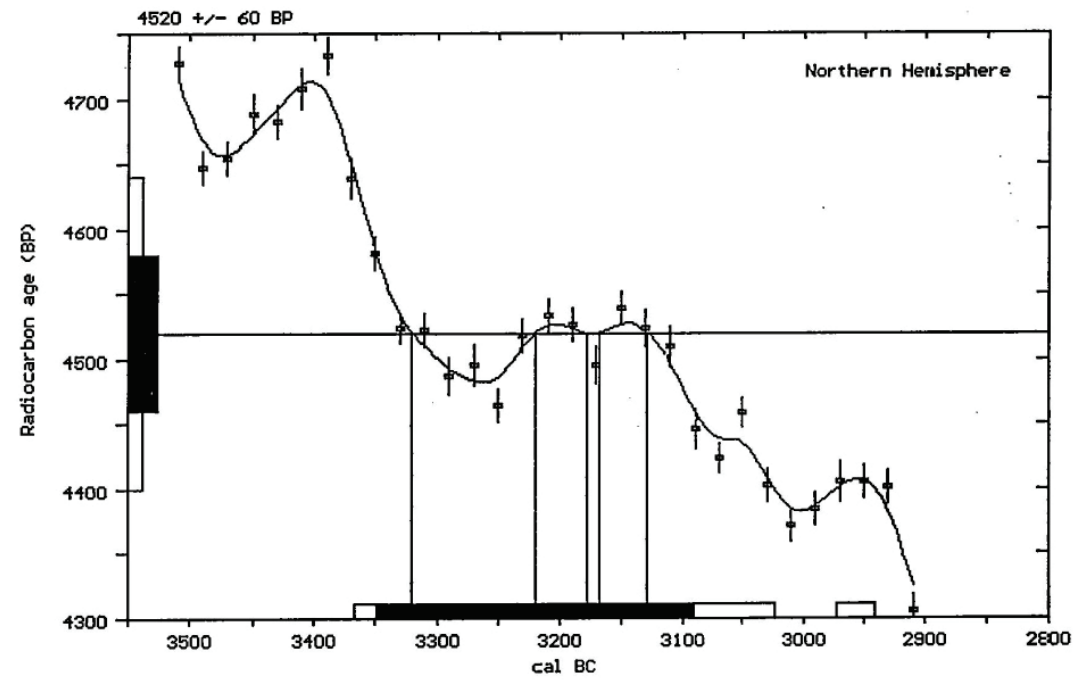

References:

Pretoria Calibration Curve for Short Lived Samples

Vogel, J. C., Fuls, A., Visser, E. and Becker, B., 1993, Radiocarbon 35(I), p73-86

A Simplified Approach to Calibrating C14 Dates

Talma, A. S. and Vogel, J. C., 1993, Radiocarbon 35(2), p317-322

Calibration - 1993

Stuiver, M., Long, A., Kra, R S. and Devine, J. M., 1993, Radiocarbon 35(I) 
CALIBRATION OF RADIOCARBON AGE TO CALENDAR YEARS

(Variables: $\mathrm{C} 13 / \mathrm{C} 12=-27.3: \mathrm{lab}$. mult $=1$ )

Laboratory Number: Beta-90044

Conventional radiocarbon age:

Calibrated results: (2 sigma, 95\% probability)

Intercept data:

Intercept of radiocarbon age with calibration curve:

1 sigma calibrated results: (68\% probability)
$260+/-60 \mathrm{BP}$

cal AD 1485 to 1690 and cal AD 1735 to 1815 and cal AD 1925 to 1950

cal AD 1655

cal $\mathrm{AD} 1535$ to 1545 and cal $\mathrm{AD} 1635$ to 1670 and cal $\mathrm{AD} 1780$ to 1795 and cal $\mathrm{AD} 1945$ to 1950

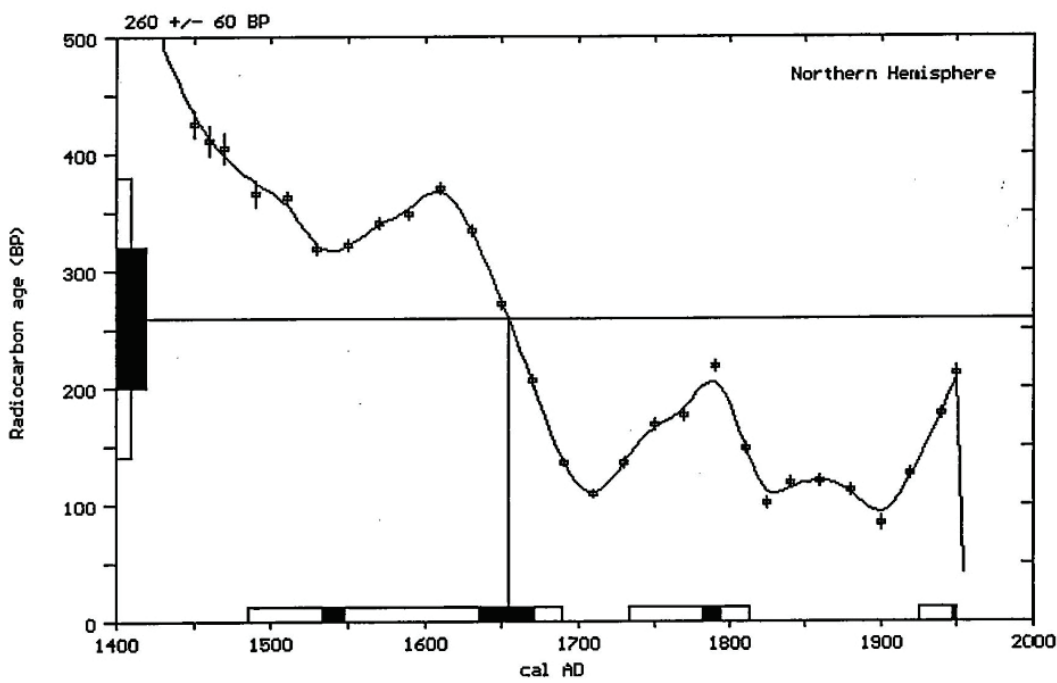

References:

Pretoria Calibration Curve for Short Lived Samples

Vogel, J. C., Fuls, A., Visser, E. and Becker, B., 1993, Radiocarbon 35(1), p73-86

A Simplified Approach to Calibrating C14 Dates

Talma, A. S. and Vogel, J. C., 1993, Radiocarbon 35(2), p317-322

Calibration - 1993

Stuiver, M., Long, A., Kra, R. S. and Devine, J. M., 1993, Radiocarbon 35(I) 


\section{CALIBRATION OF RADIOCARBON AGE TO CALENDAR YEARS}

(Variables:C13/C12=-21.7:lab mult.=1)

Laboratory Number: Beta-90045

Conventional radiocarbon age:

$3200+/-60 \mathrm{BP}$

Calibrated results:
(2 sigma, 95\% probability)

cal BC 1605 to 1380 and

cal BC 1335 to 1330

Intercept data:

Intercept of radiocarbon age with calibration curve:

cal BC 1440

1 sigma calibrated results: $\quad$ cal BC 1515 to 1410 (68\% probability)

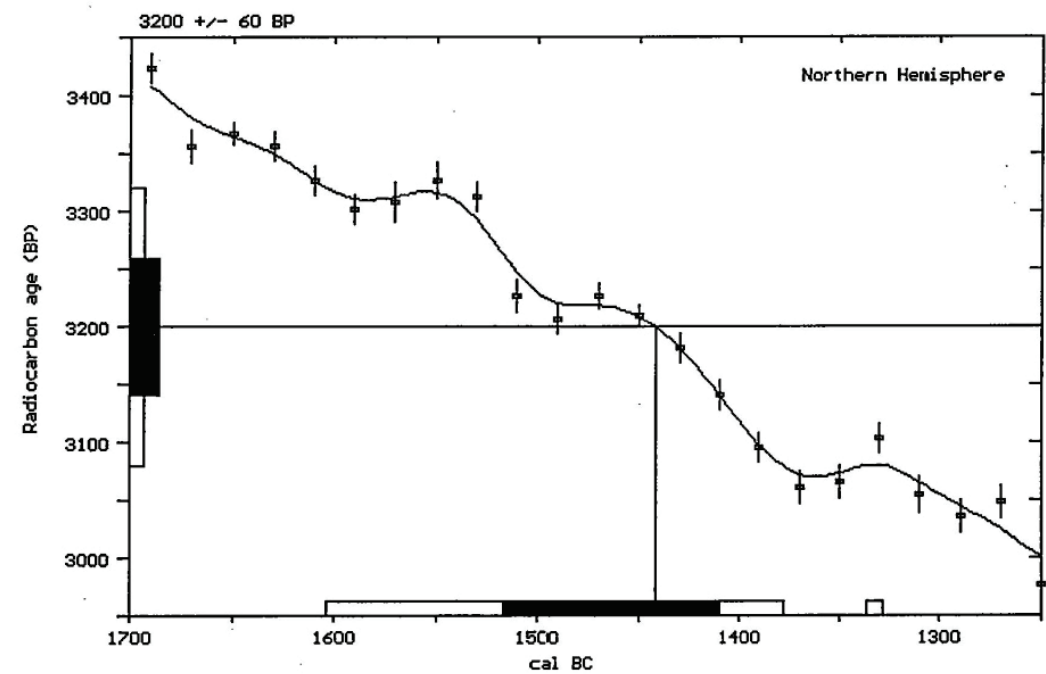

References:

Pretoria Calibration Curve for Short Lived Samples

Vogel, J. C., Fuls, A., Visser, E. and Becker, B., 1993, Radiocarbon 35(I), p73-86

A Simplified Approach to Calibrating C14 Dates

Talma, A. S. and Vogel, J. C., 1993, Radiocarbon 35(2), p317-322

Calibration - 1993

Stuiver, M., Long, A., Kra, R. S. and Devine, J. M., 1993, Radiocarbon 35(1) 


\section{CALIBRATION OF RADIOCARBON AGE TO CALENDAR YEARS}

(Variables:C13/C12=-23.1:lab mult. $=1$ )

Laboratory Number: Beta-90046

Conventional radiocarḅon age: $\quad 4610+/-60$ BP

Calibrated results: cal BC 3515 to 3285 and

(2 sigma, 95\% probability) cal BC 3245 to 3105

Intercept data:

Intercept of radiocarbon age with calibration curve:

cal BC 3360

1 sigma calibrated results: $\quad$ cal BC 3490 to 3455 and

(68\% probability) cal BC 3375 to 3340

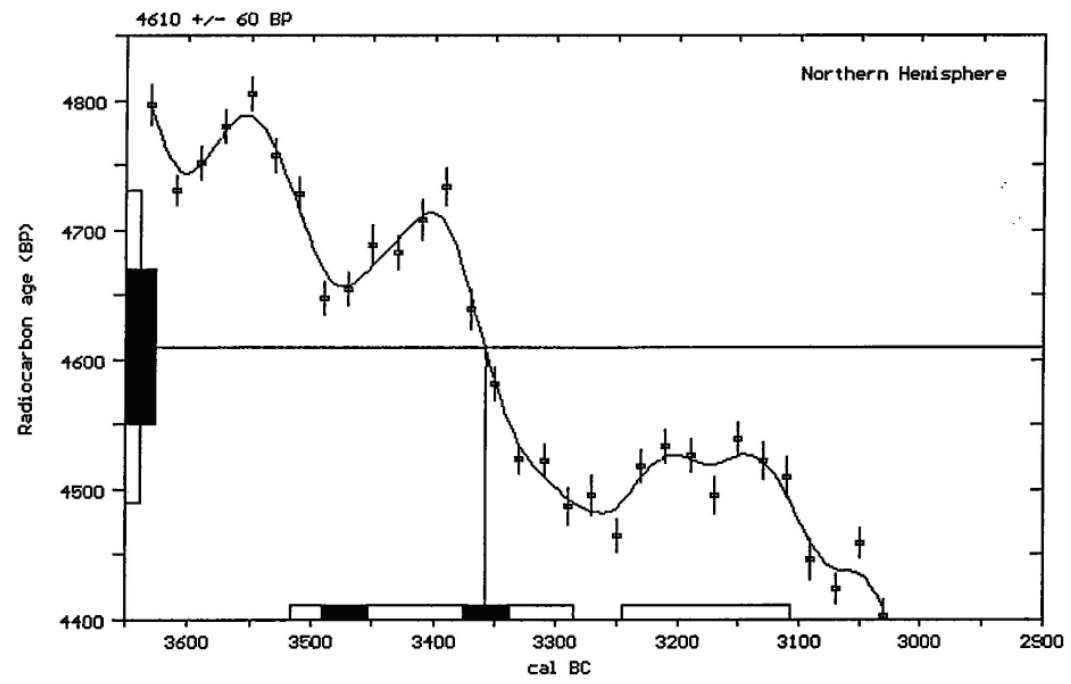

References:

Pretoria Calibration Curve for Short Lived Samples

Vogel, J. C., Fuls, A., Visser, E. and Becker, B., 1993, Radiocarbon 35(1), p73-86

A Simplified Approach to Calibrating C14 Dates

Talma, A. S. and Vogel, J. C., 1993, Radiocarbon 35(2), p317-322

Calibration - 1993

Stuiver, M., Long, A., Kra, R. S. and Devine, J. M., 1993, Radiocarbon 35(I) 


\section{CALIBRATION OF RADIOCARBON AGE TO CALENDAR YEARS}

(Variables:C13/C12=-31.2:lab mult.=1)

Laboratory Number: Beta-90047

Conventional radiocarbon age: $\quad 1260+/-70$ BP

$$
\begin{array}{cc}
\text { Calibrated results: } & \text { cal AD } 650 \text { to } 960
\end{array}
$$

Intercept data:

Intercept of radiocarbon age with calibration curve:

cal $\mathrm{AD} 775$

1 sigma calibrated results: (68\% probability)

cal $\mathrm{AD} 680$ to 875

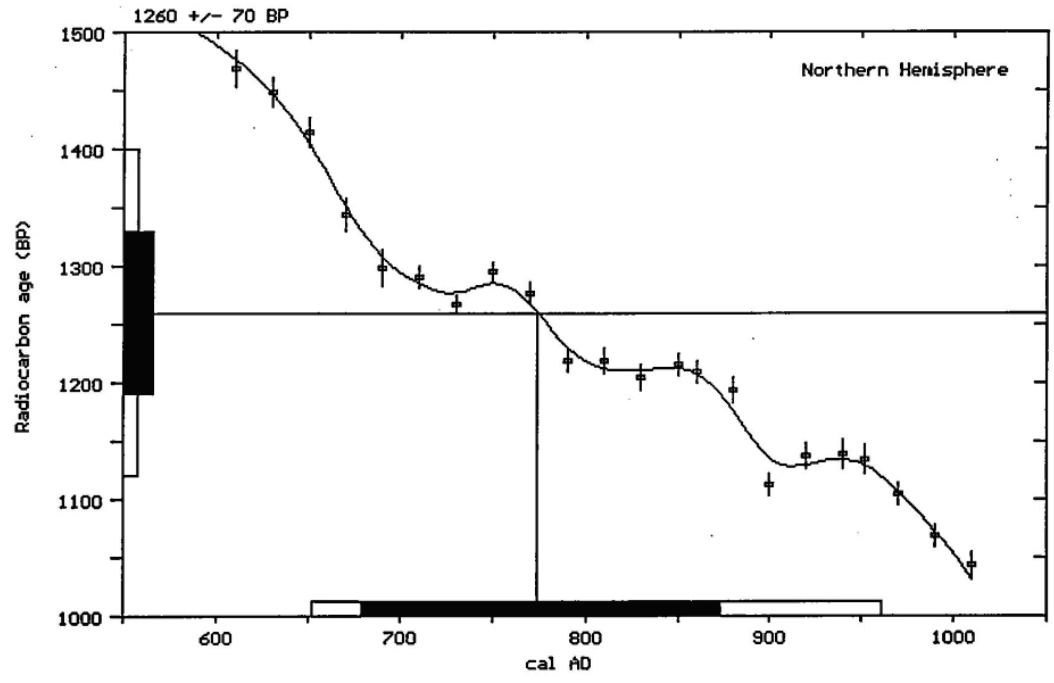

References:

Pretoria Calibration Curve for Short Lived Samples

Vogel, J. C., Fuls, A., Visser, E. and Becker, B., 1993, Radiocarbon 35(1), p73-86

A Simplified Approach to Calibrating C14 Dates

Talma, A. S. and Vogel, J. C., 1993, Radiocarbon 35(2), p317-322

Calibration - 1993

Stuiver, M., Long, A., Kra, R. S. and Devine, J. M., 1993, Radiocarbon 35(I) 


\section{CALIBRATION OF RADIOCARBON AGE TO CALENDAR YEARS}

(Variables:C13/C12=-29.1:lab mult.=1)

Laboratory Number: Beta-90048

Conventional radiocarbon age: $\quad 280+/-60 \mathrm{BP}$

Calibrated results: $\quad$ cal AD 1470 to 1680 and

(2 sigma, 95\% probability) cal AD 1745 to 1805 and

cal AD 1935 to 1950

Intercept data:

Intercept of radiocarbon age with calibration curve:

cal AD 1650

1 sigma calibrated results: $\quad$ cal $\mathrm{AD} 1520$ to 1570 and (68\% probability) cal AD 1630 to 1665

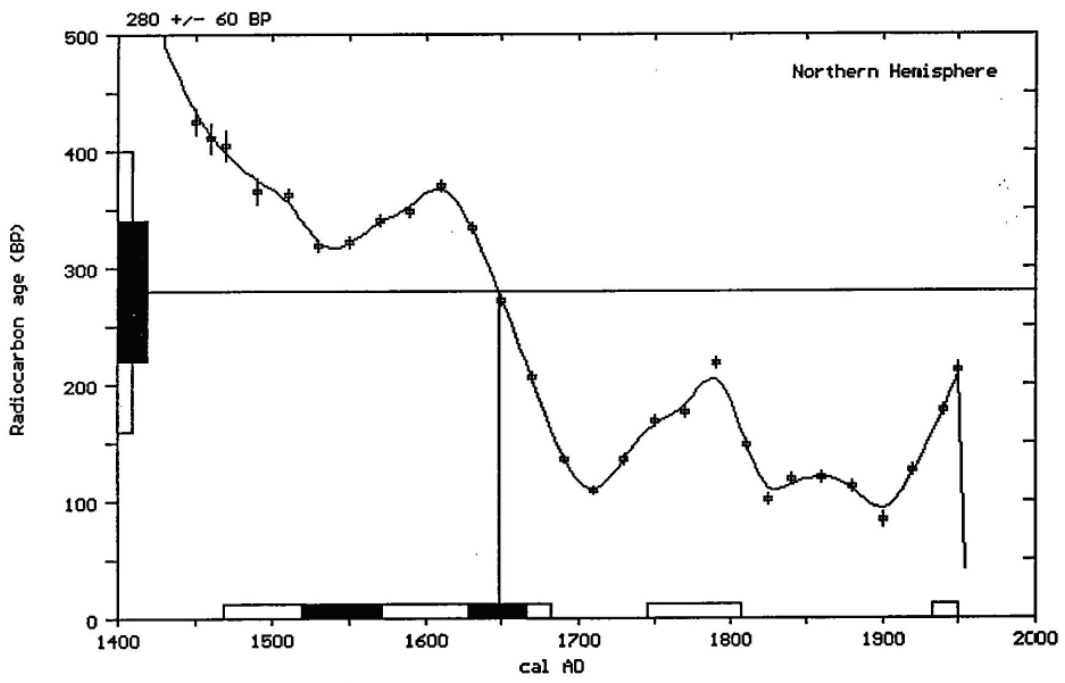

References:

Pretoria Calibration Curve for Short Lived Samples

Vogel, J. C., Fuls, A., Visser, E. and Becker, B., 1993, Radiocarbon 35(1), p73-86

A Simplified Approach to Calibrating C14 Dates

Talma, A. S. and Vogel, J. C., 1993, Radiocarbon 35(2), p317-322

Calibration - 1993

Stuiver, M., Long, A., Kra, R. S. and Devine, J. M., 1993, Radiocarbon 35(I) 


\section{CALIBRATION OF RADIOCARBON AGE TO CALENDAR YEARS}

(Variables:C13/C12=-27.7:lab mult.=1)

Laboratory Number: Beta-90049

Conventional radiocarbon age:

$100+/-60 \mathrm{BP}$

Calibrated results: (2 sigma, 95\% probability)

cal AD 1665 to 1950

Intercept data:

Intercepts of radiocarbon age with calibration curve:

cal AD 1890 and

cal AD 1905

1 sigma calibrated results: $\quad$ cal $\mathrm{AD} 1680$ to 1745 and

(68\% probability) cal $\mathrm{AD} 1805$ to 1935

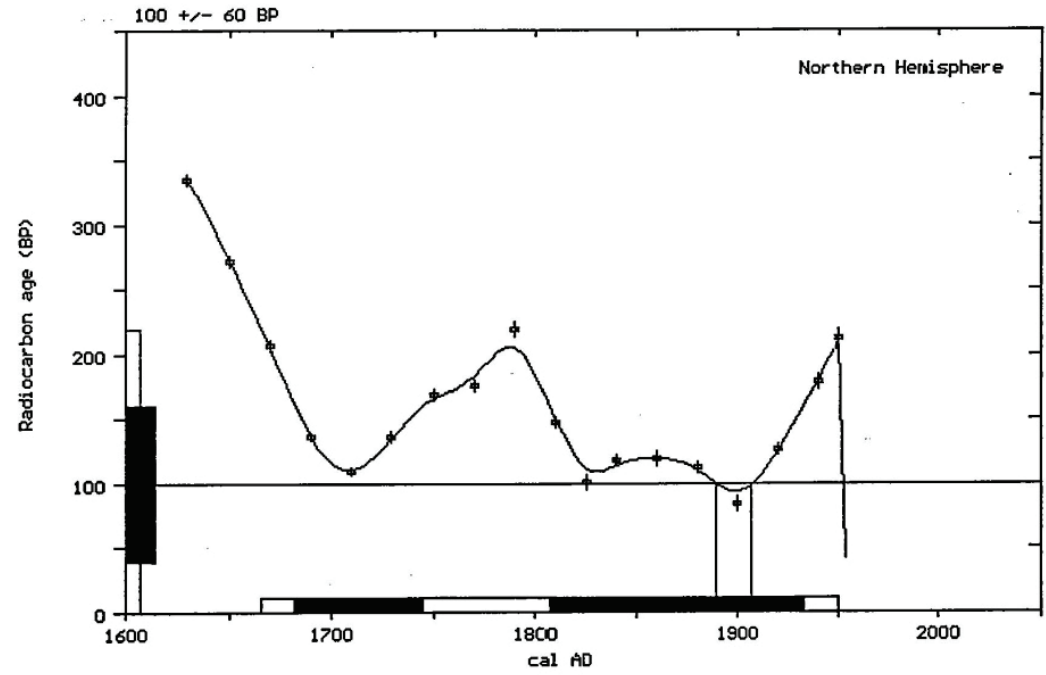

References:

Pretoria Calibration Curve for Short Lived Samples

Vogel, J. C., Fuls, A., Visser, E. and Becker, B., 1993, Radiocarbon 35(1), p73-86

A Simplified Approach to Calibrating C14 Dates

Talma, A. S. and Vogel, J. C., 1993, Radiocarbon 35(2), p317-322

Calibration - 1993

Stuiver, M., Long, A., Kra, R. S. and Devine, J. M., 1993, Radiocarbon 35(l) 


\section{CALIBRATION OF RADIOCARBON AGE TO CALENDAR YEARS}

(Variables:estimated $\mathrm{C} 13 / \mathrm{C} 12=-25: 1 \mathrm{lab}$ mult.=1)

Laboratory Number:

Beta-90050

Conventional radiocarbon age*:

$250+/-70$ BP

\section{Calibrated results: (2 sigma, 95\% probability)}

cal AD 1475 to 1825 and cal AD 1835 to 1880 and cal AD 1915 to 1950

${ }^{*} \mathrm{C} 13 / \mathrm{Cl} 2$ ratio estimated

Intercept data:

Intercept of radiocarbon age with calibration curve:

cal AD 1655

1 sigma calibrated results: (68\% probability)

cal $\mathrm{AD} 1535$ to 1545 and cal $\mathrm{AD} 1635$ to 1675 and cal $\mathrm{AD} 1770$ to 1800 and cal AD 1940 to 1950

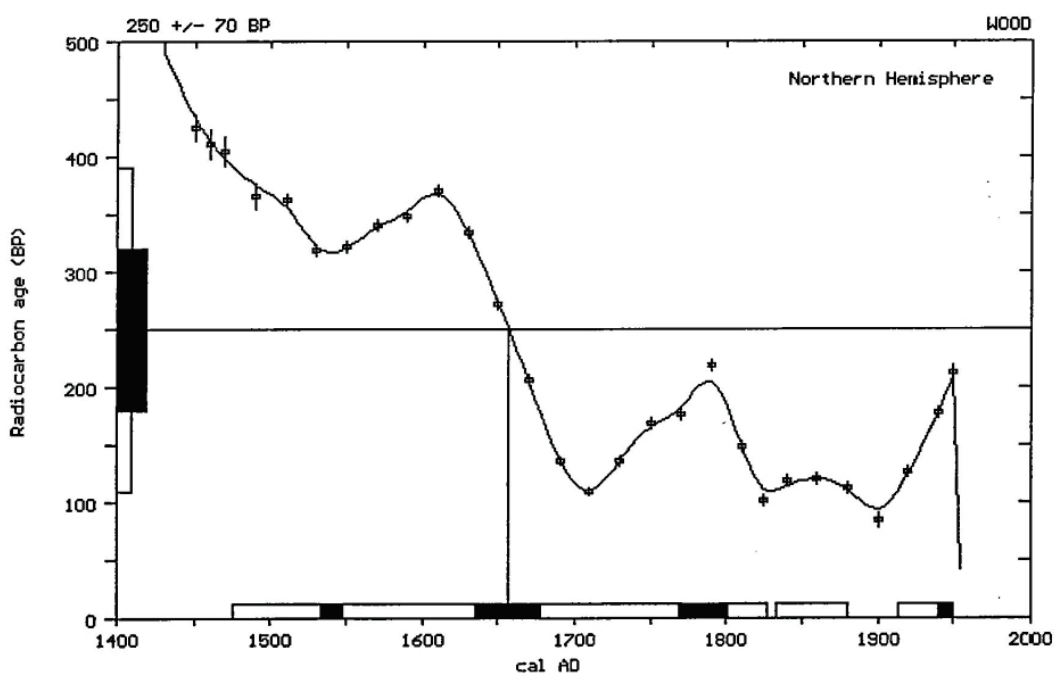

References:

Pretoria Calibration Curve for Short Lived Samples Vogel, J. C., Fuls, A., Visser, E. and Becker, B., 1993, Radiocarbon 35(1), p73-86

A Simplified Approach to Calibrating CI4 Dates

Talma, A. S. and Vogel, J. C., 1993, Radiocarbon 35(2), p317-322

Calibration - 1993

Stuiver, M., Long, A., Kra, R. S. and Devine, J. M., 1993, Radiocarbon 35(I) 


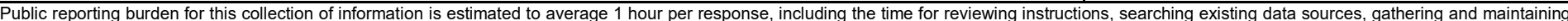

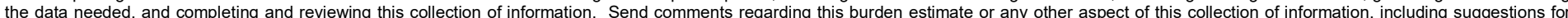

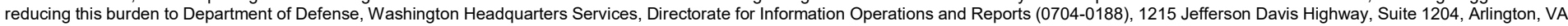

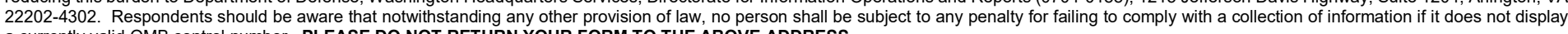
a currently valid OMB control number. PLEASE DO NOT RETURN YOUR FORM TO THE ABOVE ADDRESS.
1. REPORT DATE (DD-MM-YYYY) 2. REPORT TYPE
August 2018

\section{TITLE AND SUBTITLE}

Geomorphic Investigation of the Great Bend Region, Red River

6. AUTHOR(S)

Paul E. Albertson, Maureen K. Corcoran, Whitney Autin, John Kruger, and Theresa Foster

\section{DATES COVERED (From - To)}

\section{5a. CONTRACT NUMBER}

G2887

5b. GRANT NUMBER

W81EWF80730125

5c. PROGRAM ELEMENT NUMBER

5d. PROJECT NUMBER

5e. TASK NUMBER

5f. WORK UNIT NUMBER

8. PERFORMING ORGANIZATION REPORT NUMBER

ERDC/GSL TR-18-17

U.S. Army Engineer Research and Development Center

Geotechnical and Structures Laboratory

3909 Halls Ferry Road

Vicksburg, MS 39180-6199

9. SPONSORING / MONITORING AGENCY NAME(S) AND ADDRESS(ES)

U.S. Army Engineer District, Vicksburg

Vicksburg, MS 39180
10. SPONSOR/MONITOR'S ACRONYM(S)

11. SPONSOR/MONITOR'S REPORT NUMBER(S)

\section{DISTRIBUTION / AVAILABILITY STATEMENT}

Approved for public release; distribution is unlimited.

\section{SUPPLEMENTARY NOTES}

\section{ABSTRACT}

The U.S. Army Engineer District, Vicksburg, conducted feasibility studies to rehabilitate the levees along the Red River from Fulton, AR, to the Arkansas-Louisiana state line. In support of these studies, research was performed by the U.S. Army Engineer Research and Development Center to provide a geomorphic framework for cultural resources in the project area. This research had three specific objectives: (1) identify and map geomorphic features in the study area on 1:24,000 scale maps, (2) define geomorphic processes that are active in the study area, and (3) reconstruct the geomorphic development of the study area to understand the significance of geomorphic features in terms of both locating previously unknown archaeological sites and discovering buried sites. Field investigations and aerial photography were used to interpret the geomorphology. Approximately 6 percent of the known archeological sites are located above the floodplain on valley slopes or bluffs. The remaining 94 percent of the sites are associated with the floodplain of the various fluvial components that form the study area. Forty-six percent of flood-plain sites are located adjacent to crevasse channels. Other known archaeological sites are primarily located on the natural levee or adjacent point bars.

\begin{tabular}{|ll|}
\hline 15. SUBJECT TERMS & Flood control \\
Geomorphology & Archeological site location \\
Red River & Levees \\
\hline
\end{tabular}

16. SECURITY CLASSIFICATION OF:

\begin{tabular}{|l|l|l|}
\hline $\begin{array}{l}\text { a. } \text { REPORT } \\
\text { UNCLASSIFIED }\end{array}$ & $\begin{array}{l}\text { b. ABSTRACT } \\
\text { UNCLASSIFIED }\end{array}$ & $\begin{array}{c}\text { c. THIS PAGE } \\
\text { UNCLASSIFIED }\end{array}$ \\
\hline
\end{tabular}

17. LIMITATION OF ABSTRACT
18. NUMBER OF PAGES

185 19a. NAME OF RESPONSIBLE PERSON Maureen K. Corcoran

19b. TELEPHONE NUMBER (include area code) 6016343334 